\title{
Advies inrichting en beheer beekdal Geeserstroom
}

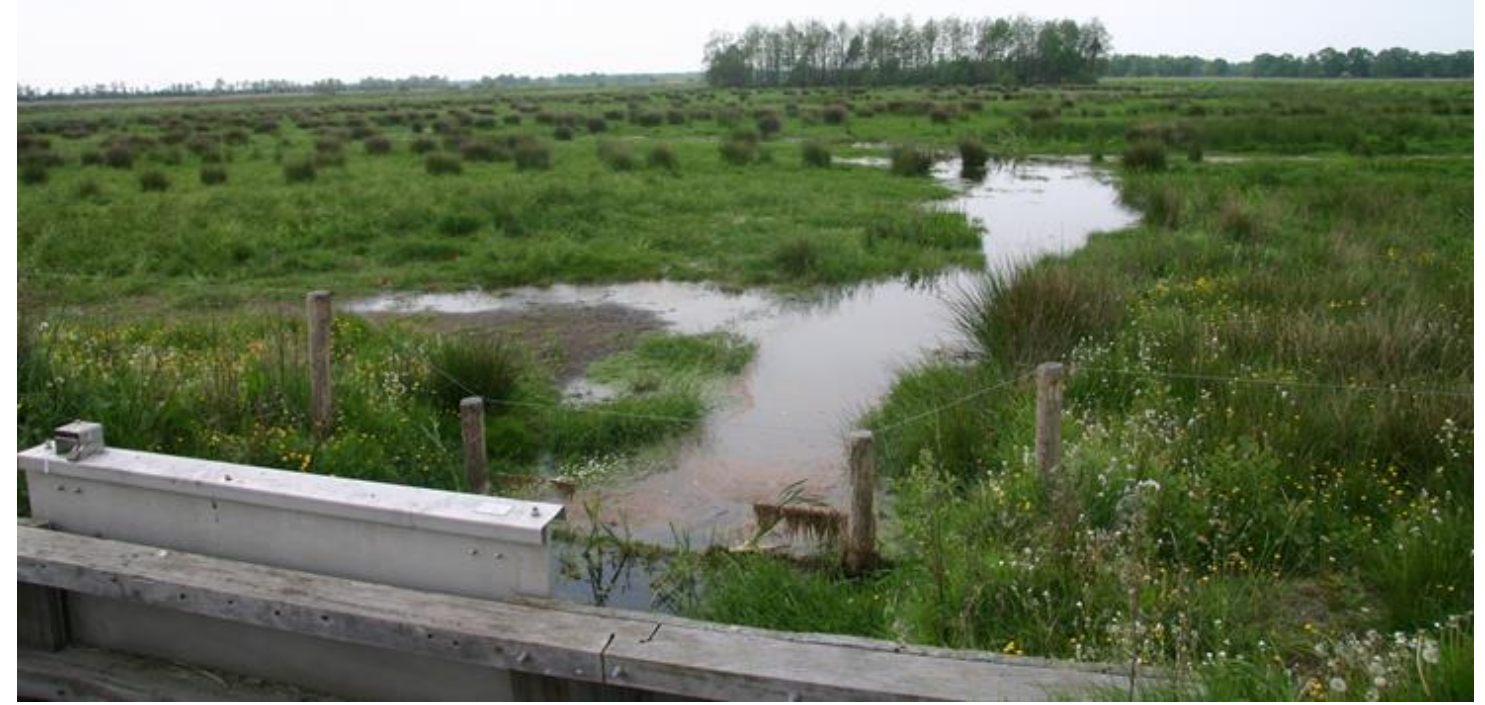

Piet F.M. Verdonschot, Ralf C.M. Verdonschot, Peter C. Jansen, Harry T.L. Massop, Ab P. Grootjans

Zoetwaterecosystemen, Wageningen Environmental Research (Alterra) Januari 2017 


\section{Auteurs}

Piet F.M. Verdonschot, Ralf Verdonschot, Peter Jansen, Harry Massop, Ab Grootjans

(correspondentie: piet.verdonschot@wur.nI)

\section{Opdrachtgever}

Waterschap Vechtstromen

\section{Projectgroep}

Arnold Lassche (Waterschap Vechtstromen), Gerhard Duursema (Waterschap Vechtstromen), (Waterschap Vechtstromen), Jiska Waaijenberg (Waterschap Vechtstromen), Bert Gosselink (Provincie Drenthe), Aarnout Rossenaar (SBB)

\section{Wijze van citeren}

Verdonschot P.F.M., Verdonschot R.C.M., Jansen P.C., Massop H.T.L. \& Grootjans A.P. (2017). Advies inrichting en beheer beekdal Geeserstroom. Notitie Zoetwaterecosystemen, Wageningen Environmental Research (Alterra), Wageningen UR, Wageningen. 129 pp.

\section{Trefwoorden}

Geeserstroom, beekdal, herinrichting,

\section{Beeldmateriaal}

Piet Verdonschot

ISBN: $978-94-6343-127-9$

DOI: http://dx.doi.org/10.18174/409213

Dit project is uitgevoerd in opdracht van het Waterschap Vechtstromen en tot stand gekomen met financiele steun van het Kennisbasisprogramma Building with Nature (KB-24-001-007) en het project $O B N$ 2013-44-BE 'Integraal natuurherstel in beekdalen door ontwikkeling van diffuse afvoersystemen, gedempte afvoerdynamiek en genuanceerd beekprofielherstel'.

@ 2017 Zoetwaterecosystemen, Wageningen Environmental Research (Alterra)

- Overname, verveelvoudiging of openbaarmaking van deze uitgave is toegestaan mits met duidelijke bronvermelding.

- Overname, verveelvoudiging of openbaarmaking is niet toegestaan voor commerciële doeleinden en/of geldelijk gewin.

- Overname, verveelvoudiging of openbaarmaking is niet toegestaan voor die gedeelten van deze uitgave waarvan duidelijk is dat de auteursrechten liggen bij derden en/of zijn voorbehouden.

Alterra aanvaardt geen aansprakelijkheid voor eventuele schade voortvloeiend uit het gebruik van de resultaten van dit onderzoek of de toepassing van de adviezen.

Notitie Zoetwaterecosystemen, Wageningen Environmental Research (Alterra)

Wageningen, januari 2017 


\section{Inhoud}

Samenvatting $\quad 5$

1 Inleiding en doel 7

1.1 Achtergrond 7

1.2 Verkenning van een nieuwe, passende oplossingsrichting 9

$\begin{array}{ll}1.3 \text { Projectdoelstelling } & 10\end{array}$

$\begin{array}{lll}1.4 & \text { Projectresultaat en producten } & 11\end{array}$

1.5 Leeswijzer 12

2. Huidige toestand en processen beekdal Geeserstroom 13

2.1 Systeemkenmerken en toestand voor de herinrichting 13

2.2 Herinrichtingsmaatregelen 16

$\begin{array}{lll}2.3 & \text { Toestand en processen na de herinrichting } & 18\end{array}$

3. Knelpunten en oplossingen 31

3.1 Hydrologie 31

$\begin{array}{lll}3.2 & \text { Bestaande gebiedsanalyses } & 31\end{array}$

$\begin{array}{lll}3.3 & \text { Aanvullende analyse } & 37\end{array}$

3.4 Modelberekeningen 44

3.5 Oplossingen voor de hydrologische knelpunten 49

3.6 Modelberekeningen $\quad 51$

3.7 Aanbevelingen t.a.v. hydrologische knelpunten 53

3.8 Mepper Hooilanden 54

3.9 Aanbevelingen om te komen tot planvorming 55

4. Broekbossen in het algemeen 56

4.1 Broekbosvegetaties 56

4.2 Broekbosfauna 60

4.3 Beheer: niets doen 65

5. Toekomstig beeld van de ontwikkeling van het landschap in het dal van de Geeserstroom

$\begin{array}{lll}5.1 & \text { Ontwikkelingen in de vegetatietypen } & 67\end{array}$

5.2 Bodemtypen en grondwaterstanden in het Geeserstroomdal 69

5.3 Broekbosontwikkeling in de Geeserstroom 70

6. Landschappelijke en ecologische ontwikkelingen 73

6.1 Potenties voor ontwikkeling broekbossen in het Geeserstroomdal 73

6.2 Scenario's in landschapsontwikkelingen 75

7. Monitoring moerasbosontwikkeling Geeserstroom 86

$\begin{array}{lr}\text { Dankwoord } & 89\end{array}$

$\begin{array}{ll}\text { Literatuur } & 90\end{array}$ 
Bijlage 1 Selectie en parameterisatie van de proefplekken

Bijlage 2 Achtergrond informatie moerasbossen

Bijlage 3 Ondersteunde informatie bij hoofdstuk 2 109

Bijlage 4 Ondersteunde informatie bij hoofdstuk 4 


\section{Samenvatting}

De in 2005 uitgevoerde herinrichting van het beekdal van de Geeserstroom bestond uit de omvorming van een regulier landbouwgebied naar een door natuurlijke waterhuishoudkundige processen aangestuurd natuurgebied, met een nevenfunctie voor waterberging. Vooraf was een $19 \mathrm{de}$-eeuwse beekdallandschap voorzien, met in het midden een stromende beekloop. Het beekdal blijkt zich in de periode tot 2016 echter ontwikkeld te hebben tot een zogenaamd doorstroommoeras, dat inmiddels een grote diversiteit aan moerasvegetaties en een zeer soortenrijke moerasvogelgemeenschap kent. Een doorstroommoeras is een mengvorm van moeras en beek en vormt qua watertype een overgang tussen stromend en stilstaand water. Naast de genoemde ecologische waarden zijn er lokaal echter ook enkele waterhuishoudkundige knelpunten en waterkwaliteitsproblemen ontstaan.

De nieuwe situatie in het Geeserstroomdal vraagt om een heroverweging van de oorspronkelijke doelen en de nu ontstane waarden. Daarnaast wil waterschap Vechtstromen zoveel mogelijk gebruikmaken van natuurlijke processen ('bouwen met natuur'), teneinde het systeem met een minimum aan beheer te kunnen laten functioneren. Eén van de mogelijkheden die het waterschap wil laten onderzoeken is het verder door ontwikkelen van het huidige doorstroommoeras, waarbij de huidige knelpunten duurzaam worden opgelost en de waterbergende functie wordt geconsolideerd. Ook moet voldaan worden aan de doelen voor de Kaderrichtlijn Water (KRW). Door zo dicht mogelijk bij de natuurlijke potenties van het beeksysteem te blijven (het doorstroommoeras), kunnen deze doelen met een minimale inspanning worden bereikt.

Dit rapport gaat vooral in op de relatie tussen moerasvorming en de dimensionering van de beekloop. Om de hydrologische knelpunten op te lossen worden verschillende maatregelen voorgesteld. De meest kansrijke maatregel is een aanpassing van het beekprofiel tot een zgn. accoladeprofiel, waarbij op een beperkt bovenstrooms traject het onregelmatige verhang wordt vergraven naar een geleidelijk aflopend verhang. De beekbedding wordt hersteld tot het voorheen geplande zomerbed, aangevuld met een verbrede, afgeplagde oeverzone. Deze zones worden ingeplant of ingezaaid met els. Voor de Mepper Hooilanden is het verlagen van het peil de eenvoudigste en meest doeltreffende oplossing om deze plas, indien gewenst, om te vormen tot het oorspronkelijk voorgenomen brongebied voor de Geeserstroom.

De analyse van de systeemrandvoorwaarden in het dal van de Geeserstroom laat nu al zien dat zich een nieuw, waardevol moeraslandschap ontwikkelt. De optie om dit doorstroommoeras verder te ontwikkelen als elzenbroekbos blijkt veelbelovend. Daarmee gaan we terug naar het landschap zoals dat tot aan de Middeleeuwen in dit gebied aanwezig was. Er zijn verschillende deelscenario's benoemd. De volgende combinatie lost de hydrologische knelpunten definitief en duurzaam op en zorgt - op termijn - voor een optimale ecologische kwaliteit:

- Plas Mepper Hooilanden: Vochtig-natte slenk.

- Traject Koemarserdijk - Bollema: Beekdalbreed begeleidend broekbos. 
- Gemaal Bollema: Ruigtemoeras.

- Traject Bollema - Goringdijk: Beekdalbreed begeleidend broekbos.

- Traject Goringdijk - Verlengde Hoogeveensevaart: Moerasbos en moerasruigte.

- Zijloop vanaf Gees: Beperkte begeleidende houtwal op de beekoever in een verder relatief open landschap.

De verschillende scenario's wijken daarmee af van het in 2004 beschreven streefbeeld. Het herstellen van de houtwallen in het smalle beekdal tussen Mepper Hooilanden en het zuidelijk deel is geen optie, omdat houtwallen niet overleven in een moerassysteem. Het laten ontwikkelen van een elzenbroek is vanuit cultuurhistorisch oogpunt goed verdedigbaar omdat dit de situatie is van voor de Middeleeuwen. In het zijbeekdal vanaf Gees (Oude Maden) kan het beekdal (veel) opener worden gehouden door maaien met rupsmaaiers. De beleefbaarheid van het gebied kan verder versterkt worden door de aanleg van dwarsdoorsteken, vlonderpaden, informatiepanelen met uitleg over natuur, (cultuur)historie en landschap, uitkijktorens, etc. 


\section{$1 \quad$ Inleiding en doel}

\subsection{Achtergrond}

\section{Historie en ontwikkelingen}

In het kader van de 'Herinrichting Mars- en Westerstroom' zijn in 2005 in het beekdal van de Geeserstroom ingrijpende inrichtingsmaatregelen uitgevoerd, waarbij een regulier landbouwgebied is omgevormd tot een door natuurlijke waterhuishoudkundige processen aangestuurd natuurgebied met een functie voor waterberging. Het gebied is sindsdien geheel in eigendom en beheer bij Staatsbosbeheer. Het waterschap Vechtstromen is verantwoordelijk voor het waterbeheer. De belangrijkste uitgevoerde herstelmaatregelen zijn:

- Bovenstrooms (Mepper Hooilanden) is circa 30 hectare landbouwgebied afgegraven en vernat om moerasvorming op gang te brengen.

- Er zijn bovenstrooms in De Marsen enkele ondiepe slenken gegraven om het water richting beek te sturen.

- Er is door de laagste delen van het beekdal een maaiveld volgend, ondiep beekprofiel gegraven (ca. 4 meter breed en $40 \mathrm{~cm}$ diep).

- Sloten en greppels in zowel beekdal als in delen van het infiltratiegebied (boswachterij Gees) zijn grotendeels gedempt om het hydrologisch regime in het beekdal optimaal af te stemmen op de natuurfunctie.

- Aan de zuidzijde van het beekdal is een bergingsgebied (Roonboom) ingericht. Dit is bedoeld om bij extreme neerslag piekafvoeren tijdelijk op te vangen, zodat het water later weer gedoseerd naar de benedenloop van het beeksysteem teruggevoerd kan worden.

- Ten behoeve van de drooglegging van het dorp Gees en een landbouwgebied ten noordoosten van het beekdal zijn twee gemalen geplaatst, resp. gemaal Oldema en gemaal Bollema.

- $\quad$ r is een tweetal vispassages aangelegd en er zijn enkele poelen gegraven.

Op dit moment, meer dan 10 jaar na uitvoering, blijken een aantal ontwikkelingen af te wijken van wat destijds verwacht c.q. voorspeld werd. Achteraf zijn deze ontwikkelingen niet verrassend, aangezien veel van de ingrepen een experimenteel karakter hadden. Het streven was gericht op een zo natuurlijk mogelijke afstroming van grond- en oppervlaktewater om de verdroging door de op agrarisch gebruik gerichte waterhuishouding van het dal tegen te gaan. Hierbij waren de kansen op maximaal herstel van die waterhuishouding groot, omdat het gebied een omvangrijk en schoon intrekgebied omvat dat bestaat uit een boswachterij met een min of meer natuurlijk grondwaterregime. Er was in het plan een $19^{\text {de }}$-eeuws landschap voorzien waardoor een beek (KRW-type R4-R5 m.a.w. boven- en middenloop) zou gaan stromen.

Het experiment is echter anders gelopen. Momenteel zijn in het gebied verschillende processen zichtbaar: enerzijds eutrofiëring in die delen waar meer voedingsstoffen beschikbaar zijn (door nalevering uit de bodem of door voedselrijk landbouwater) en anderzijds de invloed van voedselarmer grondwater dat zich in de vegetatie in en op de flanken van enkele delen van het beekdal manifesteert. Daarnaast heeft zich (al dan niet tijdelijk) een zeer soortenrijke moerasvogelgemeenschap gevestigd, waarvoor het gebied als broed- en pleisterplaats zeer geschikt is gebleken. 
Al deze ontwikkelingen hebben in de omgeving bij verschillende mensen en groeperingen geleid tot vragen over 1) de natuurbeelden, die nogal afwijken van de verwachtingen met betrekking tot het ontstaan van een "ouderwets" vooral cultuurhistorisch georiënteerd landschap, 2) de aantalsontwikkelingen binnen de weidevogels, 3) de afname in recreatieve beleving door te natte paden en 4) een aantal wateroverlastsituaties die zich voordoen onder extreem natte weersomstandigheden aan de randen van de essen en nabij gemaal Bollema.

\section{Knelpunten}

Hoewel er onmiskenbare natuurwaarden in het gebied zijn ontstaan (vooral ornithologisch) is op een aantal onderdelen nog een verbeteringsslag nodig, in ieder geval voor de waterhuishouding en mogelijk ook voor de ecologische kwaliteit.

De waterhuishoudkundige problemen hangen met drie zaken samen:

1. Het geringe verhang in het bovenstroomse deel van de Geeserstroom.

2. De aanleg van een maaiveld-volgende en ondiepe beek.

3. De keuze om géén onderhoud aan de nieuw gegraven beek uit te voeren. Sinds de herinrichting is de beek niet gemaaid. Dit heeft tot gevolg gehad dat grote delen van de beek en het beekdal inmiddels dichtgegroeid zijn met helofyten als Riet, Grote lisdodde, Grote egelskop en Liesgras.

Deze drie zaken hebben geleid tot enkele belangrijke waterhuishoudkundige knelpunten:

\section{Functioneren gemaal Bollema.}

De reactie van het waterhuishoudkundige systeem bij gemaal Bollema wijkt aanzienlijk af van wat in het inrichtingsplan was beoogd. Onder normale omstandigheden blijkt de oppervlaktewaterstand plaatselijk in het Geeserstroomgebied fors (tot ca. $1 \mathrm{~m}$ ) hoger dan voorzien in het inrichtingsplan. Dit levert de volgende problemen op:

a. Het gemaal moet het water uit het landbouwgebied structureel hoger opvoeren dan in het inrichtingsplan was voorzien. Dit leidt tot hogere energiekosten.

b. Het buffergebied staat continu onder water en functioneert niet zoals oorspronkelijk bedoeld.

c. Op enkele plekken zijn de randen van de akkers op de essen tussen Bollema en de Tilweg te nat.

Ook in (extreem) natte situaties is de oppervlaktewaterstand hoger dan in het inrichtingsplan was voorzien. Dit leidt tot de volgende problemen:

a. Water dat wordt uitgemalen door gemaal Bollema loopt op een aantal plaatsen weer over het maaiveld en de weg terug het bemalingsgebied in.

b. De opvoerhoogte van het gemaal komt buiten het bereik van de pomp. Daarmee neemt de efficiëntie van het gemaal af en moet er harder worden gepompt.

\section{Functionaliteit bergingsgebied Roonboom}

Het gevolg van de situatie bij gemaal Bollema is dat het bergingsgebied Roonboom onder de tot nu toe voorkomende extreme omstandigheden niet voor de volle honderd procent benut wordt, omdat bij grote neerslaghoeveelheden het surplus aan water vertraagd afstroomt naar dit bergingsgebied. Overigens betekent dit wel dat door klimaatveranderingen met extremere omstandigheden dan tot nu toe zijn voorgekomen, nog extra bergingscapaciteit over is. De toestroming van water vanaf bovenstrooms zal dan vermoedelijk boven een bepaalde drempel sterk toenemen omdat het een veel groter stroombed boven maaiveld omvat. 
Optimalisatie van de inzet van het gebied is dus wenselijk, zij het dat de noodzaak hiertoe afhangt van de gevolgen benedenstrooms en voorgesorteerd zou moeten worden op toekomstige klimaatscenario's.

Naast deze twee kwantiteitsproblemen wordt door sommige betrokkenen nog een aanvullend landschapsecologisch fenomeen als knelpunt ervaren.

\section{Mepper Hooilanden}

Bovenstrooms is bij de aanleg het landbouwgebied Mepper Hooilanden afgegraven, met als doel de ontwikkeling van een moerasgebied dat op termijn als belangrijk brongebied voor de Geeserstroom zou moeten gaan fungeren. Nu blijkt dat verlanding vanuit de oevers niet of nauwelijks plaatsvindt en lijkt er een stabiele situatie met open water te zijn ontstaan. Dit wijkt af van het oorspronkelijke doel. Uit een eerste landschapsecologische analyse komt de hypothese naar voren dat een hydrologisch neutrale situatie is ontstaan waarbij de grondwaterstand zeer weinig fluctueert. De plas ligt op een positie in het landschap waar een aanzienlijke grondwatervoeding vanuit diepere bodemlagen en/of vanuit de aangrenzende boswachterij (voormalig hoogveenareaal) de huidige vrijwel natuurlijke oppervlakte-afvoer over het maaiveld en de verdamping compenseert. De aanwezigheid van ijzeroerbanken aan de westzijde en een pioniervegetatie met soorten van fluviatiel milieu wijzen op een buffering die op termijn mogelijk tot laagveenvorming kan leiden. De bij de inrichting afgegraven veraarde veenpakketten duiden ook op deze situatie. De golfslag van het nu aanwezige grote oppervlakte open water, de voedselrijkdom, het geringe doorzicht, de ganzenvraat, de begrazing door runderen en de geringe fluctuaties zijn tot nu toe oorzaak van het achterwege blijven van verlandingsvegetaties. Vanaf de westzijde van de plas zijn zeker aanzetten tot de ontwikkeling van helofyten vegetaties aanwezig en vestigen zich Holpijp-velden.

\subsection{Verkenning van een nieuwe, passende oplossingsrichting}

De ontstane situatie in het Geeserstroomdal vraagt om een nieuwe overweging van de oorspronkelijke doelen, de ontstane waarden en de toekomstige mogelijkheden die passen in het huidige beleid. De bij de inrichting gekozen doelen passen niet in het systeem functioneren van dit beekdal met dergelijk laag verhang. De huidige ontwikkelingen tonen nieuwe kansen op waarden die wel passend zijn. Eén van de mogelijkheden die het Waterschap Vechtstromen daarom wil laten onderzoeken is het verder ontwikkelen van het huidige Geeserstroomdal in de richting van een doorstroommoeras. Een doorstroommoeras is een mengvorm van moeras en beek en vormt typologisch een overgang tussen stromend en stilstaand water in een dal met een gering verhang en een langzame stroming.

Waarom kijken naar een doorstroommoeras m.a.w. naar broekbosontwikkeling? In vlakke gebieden, zoals veel van het Nederlandse Pleistoceen dat vooral door regenwater wordt gevoed, is van nature sprake van een mengvorm van moeras en beek of een doorstroommoeras. Deze 'moerasbeken' vormen typologisch een overgang tussen stromend en stilstaand water met een gering verhang en een langzame stroming.

Het blijkt dat momenteel een groot aantal waterschappen in "hoog" Nederland" met KRWwaterlichamen (de KRW-typen langzaam stromende boven- (R4), midden- (R5) of benedenlopen (R6) op zand) binnen hun beheergebied tegen vergelijkbare processen en dus vragen aanloopt als die zijn opgetreden in het Geeserstroomdal. Na het uitvoeren van 
maatregelen blijken zich moerassituaties i.p.v. een beek te ontwikkelen omdat onvoldoende verhang en daardoor onvoldoende stroming aanwezig is. Voor de KRW is echter het watertype 'moerasbeek' in Nederland niet apart beschreven maar is gerangschikt onder de beken. Echter de beekstreefbeelden noch veel van de beekherstelmaatregelen passen op deze waterlopen met dergelijk gering verhang. $\mathrm{Er}$ is daarom voor deze moerasbeken vanuit de KRW behoefte aan een apart watertype, inclusief een bijbehorende

beoordelingsmethode. STOWA heeft hiertoe een project opgestart dat hier invulling aan geeft.

Een tweede ontwikkeling die gaande is bij de waterschappen is het streven naar meer natuurlijke systemen die zichzelf in stand houden tegen veel lagere onderhoudskosten, het zogenaamde building-with-nature principe (BwN). Het basisprincipe achter BwN is het in gang zetten van de natuurlijke processen door het plegen van een eenmalige ingreep waarna het systeem zichzelf organiseert en verder ontwikkelt. Building-with-nature in beekdalen betekent het gebruiken van beek-, beekdal- en stroomgebiedsprocessen om te komen tot zelfregulerende beekdalsystemen door het uitvoeren van, vaak eenmalige, kosteneffectieve maatregelen. De kosten worden sterk gereduceerd door het minimaliseren van de ingreep en het bijna geheel wegvallen van onderhoud nadien. In het Geeserstroomdal zal na een eenmalige ingreep een doorstroommoeras ontstaan dat zich op termijn zonder al te veel menselijk ingrijpen in stand weet te houden. Ook vanuit natuurbeheeroogpunt gaan de kosten sterk omlaag omdat maaibeheer veel meer kost dan bijna niets doen in een broekbos. Begrazen in een broekbos is ook uit den boze waarmee deze post ook wegvalt.

Een derde reden bij een doorstroommoeras is de lagere hydraulische weerstand van een broekbos t.o.v. de huidige ruigten. Broekbos heeft een meer open ondergroei t.g.v. beschaduwing en biedt daarmee tijdens hogere afvoeren een beter doorstroomprofiel. Met een broekbos wordt daarom bijgedragen aan de oplossing van de hydrologische knelpunten. Ten vierde heeft een broekbos een hoge intrinsieke natuurwaarde. De vegetatie herbergt nog steeds veel elementen van een open landschap maar is ijler en tegelijk is de faunistische rijkdom hoog en krijgen ook veel bijzondere mossen, paddenstoelen, schimmels en andere organismengroepen kansen.

Ten vijfde vormen doorstroommoerassen vaak geen aaneengesloten bos maar komen er op trajecten met meer verval 'verbindingsbeken' voor die droger zijn in het dal en een duidelijke stromende beek hebben. Dit patroon verhoogt in sterke mate de diversiteit en belevingswaarde van een moerasbeek. Op dergelijke plaatsen liggen mogelijkheden om dwars op de beken fiets- en of wandelpaden te situeren wat de belevingswaarde verder doet toenemen.

\subsection{Projectdoelstelling}

Het doel is het verrichten van een verkenning van de optimalisatiemogelijkheden van de zich momenteel ontwikkelende ecologische kwaliteit van het beekdal van de Geeserstroom in de richting van een doorstroommoeras, waarbij als nevendoel geldt het aandragen van oplossingsmogelijkheden van bestaande hydrologische knelpunten.

De globale onderzoeksvraag luidt:

Wat is er nodig om het beekdal van de Geeserstroom zodanig in te richten, c.q. te beheren dat: 
(1) er voor nu en in de toekomst een acceptabele, maar - in ieder geval op termijn onderhoudsarme waterhuishouding ontstaat;

(2) er zich een ecologische kwaliteit ontwikkelt die op natuurlijke wijze zonder al te veel menselijk ingrijpen functioneert in het stroomgebied en die voldoet aan de wensen van zowel provincie, Staatsbosbeheer als het waterschap.

Het gevraagde onderzoek maakt deel uit van het KRW-programma van waterschap Vechtstromen en moet leiden tot een optimale combinatie van aquatische en terrestrische natuurdoelen.

Voor wat betreft de waterhuishoudkundige problemen (gemaal Bollema en bergingsgebied Roonboom, zie boven) is de veronderstelling dat deze in principe wellicht opgelost kunnen worden door op de juiste plek natuurtypen te realiseren met de juiste hydraulische weerstand. Zo mag aangenomen worden dat ontwikkeling van in het bijzonder broekbos zeker op termijn - zal leiden tot een geringere weerstand in het systeem en daarmee de problemen bij het bovenstroomse gemaal vermindert. Onduidelijk is echter in welke mate dat het geval is en welke locaties vervolgens in aanmerking komen. Daarbij is het belangrijk dat deze vraag beantwoord wordt vanuit zowel een hydraulisch, ecologisch als landschappelijk perspectief. Ook is het belangrijk dat duidelijk wordt welke vorm van (overgangs-)beheer noodzakelijk is om te komen tot een robuuste vorm van moeras- en moerasbeek-natuur. Van belang is ook het antwoord op de vraag naar de kansen op moerasvorming in de Mepper Hooilanden bij ongewijzigd beheer.

\subsection{Projectresultaat en producten}

Het resultaat van het onderzoek bestaat uit:

1. Een overzicht van maatregelen waarmee de huidige knelpunten in de waterhuishouding worden opgelost. a) Hierbij wordt de optie onderzocht of en waar het mogelijk is de afvoer uit het bovenstroomse van de Goringdijk liggende watersysteem te versterken door via eenmalige ingrepen (plaggen langs de laagste delen) broekbosontwikkeling te stimuleren. b) Een indicatie over de noodzaak, behoud, verwijdering of aanpassing van een buffer achter gemaal Bollema. c) Een indicatie van mogelijkheden om moerasvorming in de Mepper Hooilanden te stimuleren, met een toetsing op basis van haalbaarheid en effectiviteit.

2. Kaart met daarop een grofmazige schets van de mogelijke landschapsecologische ontwikkelingen t.a.v. moerasbos op lange termijn in de richting van een onderhoudsarm watersysteem in een doorstroom- en beekmoeras.

3. Inzicht in grond- en oppervlaktewaterstanden die horen bij een beekmoeras in een vlak dal en hoe deze zich verhouden tot het inrichtingsplan en de huidige situatie.

4. Een monitoringsplan met aandacht voor hydrologie (bv. waterbergingsparameters), waterkwaliteit, ecotopen en indicatoren voor landschapsontwikkeling (bv. indicatieve plant- en diersoorten, luchtfoto's onder verschillend gemiddelde maar ook extreme omstandigheden). 


\subsection{Leeswijzer}

Analyse van de huidige toestand en processen

- Systeemkenmerken

- Uitgevoerde maatregelen

- Effecten in termen van:

o waterhuishouding

- grond- en oppervlaktewaterkwaliteit

o fora en fauna

Huidige trends

en knelpunten

Analyse hydrologische knelpunten en oplossingen

- Bestaande analyses (wat weten we?)

- Analyse huidige toestand op basis van:

- metingen, kaartmateriaal en verslagen (wat kunnen we afleiden?)

- hydrologische modelberekeningen [4 plekken]

(wat zeggen modelberekeningen?)

- Vertaling naar oplossingen

o inventarisatie onderhoudsarme maatregelen

- Nieuwe toestand

$\circ$ hydrologische modelberekeningen effecten maatregelen

Kenmerken broekbossen (wat zijn broekbossen?)

- Bosvegetatietypen

- Broekbosfauna

o incl. samenhang met milieu-omstandigheden

Analyse van de toekomstige ontwikkelingen

- Bosvegetatietypen

o bodem

○ natheid

○ voedselrijkdom

Kaart potentiële toekomstige

broekbossen Geeserstroomdal

Kansrijke oplossingen voor knelpunten in

scenario's (wat zijn alternatieve oplossingsrichtingen?)

- Deelgebieden

- Mepper hooiplas

Koemarserdijk - Bollema

- Gemaal Bollema

Bollema - Tilweg en Tilweg - Goringdijk

Goringdijk - Verlengde Hoogeveense vaart

Zijloop vanaf Gees

Monitoring moerasbosontwikkeling 


\section{Huidige toestand en processen beekdal Geeserstroom}

Aanvullende informatie over de Huidige toestand en processen beekdal Geeserstroom is opgenomen in Bijlage 3.

\subsection{Systeemkenmerken en toestand voor de herinrichting}

\section{Ligging}

Het stroomgebied van de Geeserstroom (figuur 2.1) ligt in het zuidoostelijke deel van Drenthe en vormt het noordelijke deel van het watersysteem Loodiep (Torenbeek 1999). Het Drents Plateau loopt vanaf hier af in zuidelijke richting. Relatieve hoogtes in de omgeving zijn de hogere essen van de Mepper Dennen, de dorpen Meppen, Gees, Oosterhesselen en Zwinderen en de hoogte van de Boswachterij Gees. Tussen deze hoogtes ligt aan de westzijde het beekdal van de Geeserstroom. In het noordelijk deel is het dal zichtbaar in de boswachterij en het Geeserbinnenveld. Laagtes zijn verder aanwezig in veentjes, de Zuidmaden, Mepperweiden, Bollema, in het dal van de loop door de Oude Maden en lage delen bij Gees.

De Geeserstroom (hier nog Marsstroom genaamd) ontstaat in de Mepper Hooilanden, Koemarsen en de Marsen en stroomt in zuidelijke richting af. Deze gebieden ontvangen water vanuit de hoger gelegen westelijke gebieden, de Boswachterij Gees, Dennekamp en in het noorden de Mepper Dennen. Het middenstroomse gedeelte ligt in de velden ten noorden van de Goringdijk, Bollema, Zeekerma en Bergstukken. De benedenstroom ligt ten zuiden van de Goringdijk in de velden Klinkerberg en Roonboom. De Geeserstroom gaat bij Zwinderen over in het Loodiep die vervolgens afwatert in het Kanaal Coevorden-Zwinderen (Werkgroep Geeserstroom 2004).

\section{Hoogteligging}

In lengterichting ziet het verloop van het verhang van de Geeserstroom er als volgt uit (figuur 2.2; Werkgroep Geeserstroom 2004)):

- $\quad$ Zeer gering in de Mepper Hooilanden tot ongeveer de Tilweg.

- Vrij sterk tussen de Tilweg en $0.5 \mathrm{~km}$ bovenstrooms van de samenkomst met de loop vanuit Gees $(45 \mathrm{~cm} / \mathrm{km})$.

- $\quad$ Nihil in het meest benedenstroomse deel.

- $\quad$ Sterk in het bovenstroomse deel van de loop vanuit Gees.

- $\quad$ Vrij sterk in het benedenstroomse deel van de loop vanuit Gees.

\section{Waterhuishouding}

Er vindt een grondwaterstroming plaats van het noordelijke deel van de boswachterij in de richting van de Mepper Hooilanden. De Werkgroep Geeserstroom (2004) concludeert dit uit de grotere stijghoogte van de peilbuizen in de boswachterij dan in de peilbuizen in de Mepper Hooilanden. De stijghoogte van de peilbuizen in de boswachterij zakt in droge perioden soms dieper weg dan de hoogte van het maaiveld in de Mepper Hooilanden. Dit indiceerde het belang aan van vernatting van de boswachterij voor de kwel in de Mepper Hooilanden. Het grondwater in de Mepper Hooilanden, de Marsen en in het zuiden van de Roonboom heeft een lithoclien (grondwaterachtig) karakter. 


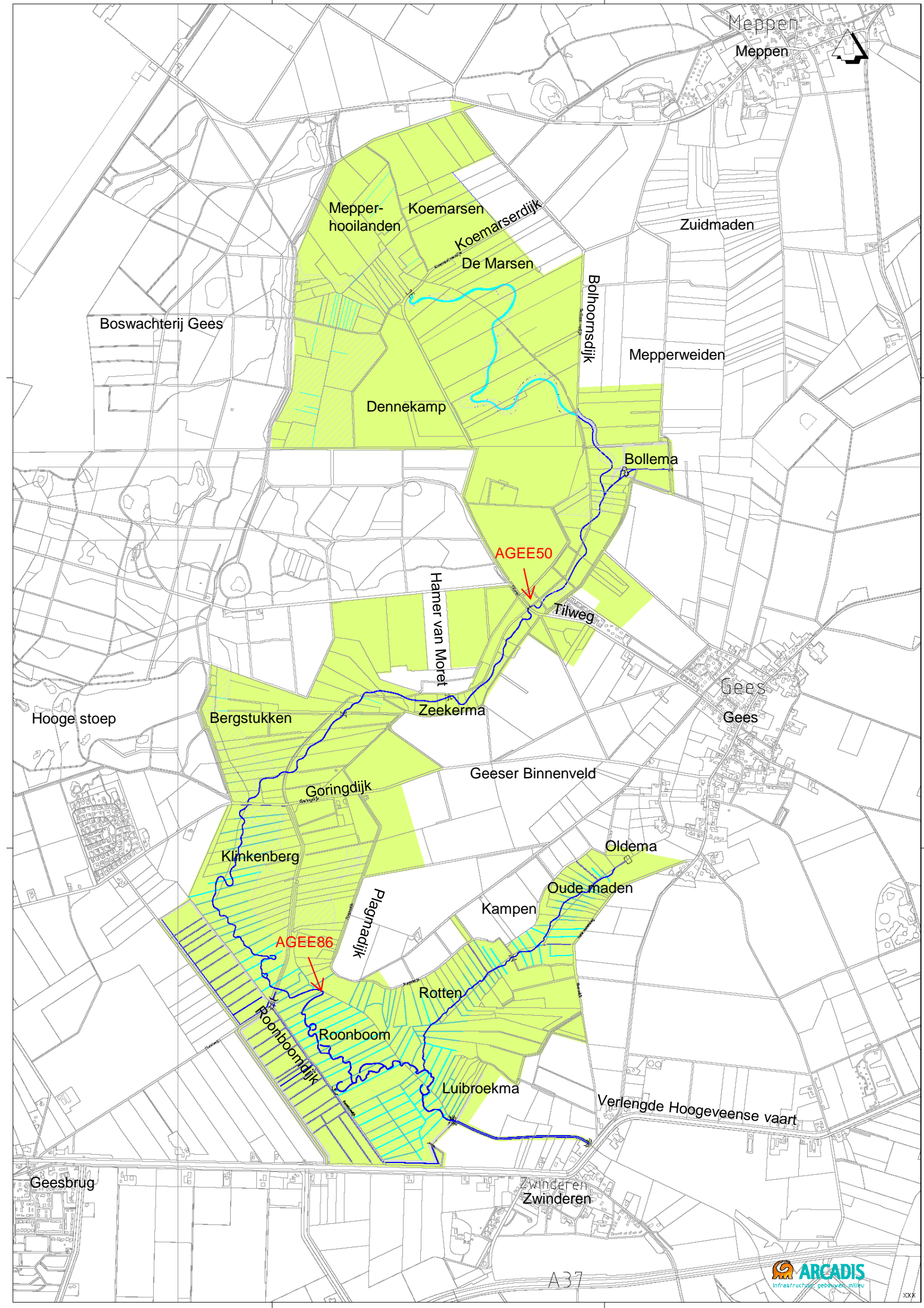

Figuur 2.1 Projectgebied (groen) met Geeserstroom (blauw), bemonsteringslocaties chemie (rood) en toponiemen. 


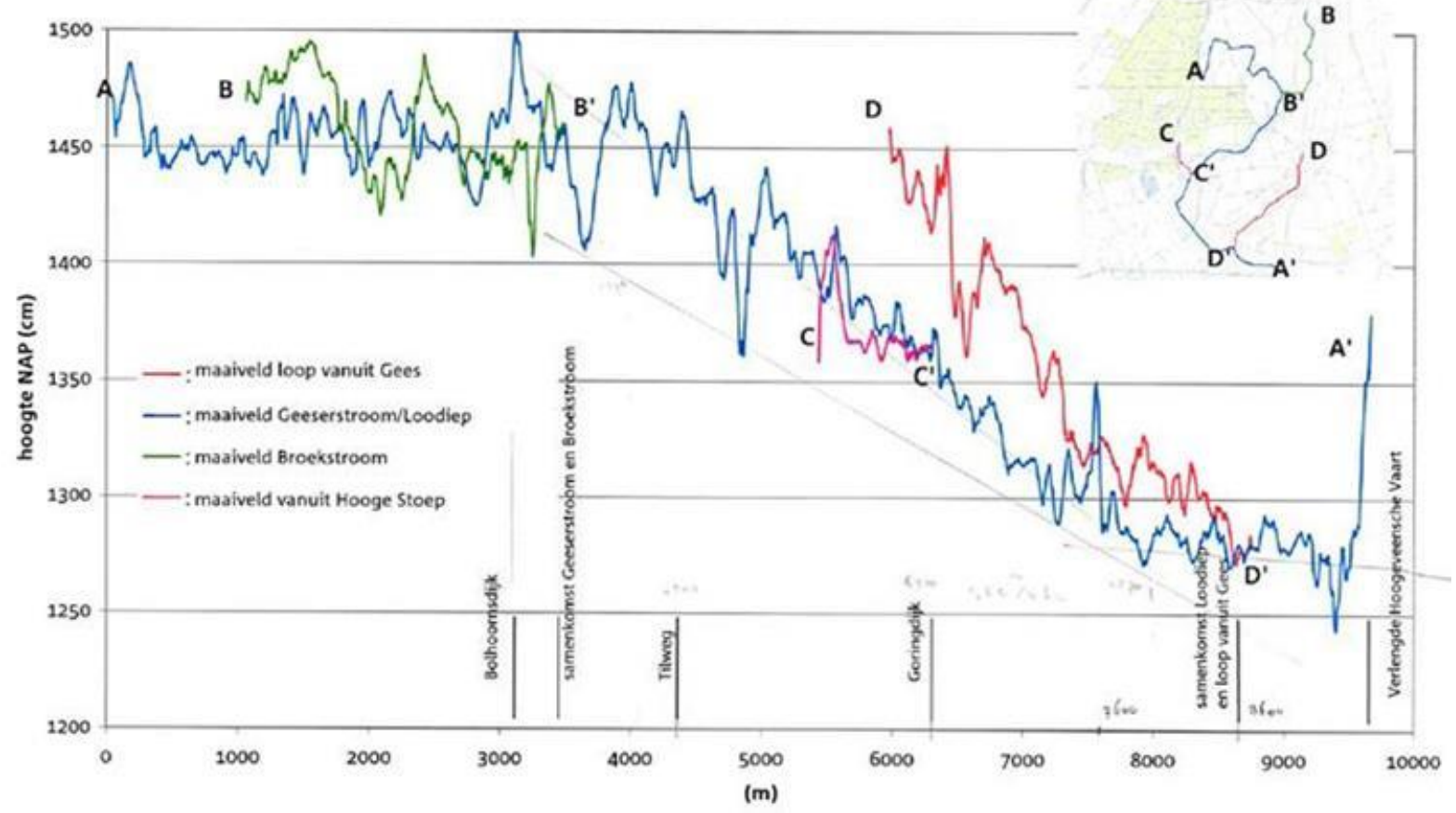

Figuur 2.2 Lengtedoorsnede door de laagste delen van het Geeserstroomdal (Werkgroep Geeserstroom 2004).

\section{Maatregelen voor de herinrichting}

Voorafgaand aan het herstelproject was er nog niet veel gedaan om de verstoringen in het beekdal van de Geeserstroom op te heffen. Hier en daar is in de houtwallen en -singels meer structuur aangebracht om het oude karakter te herstellen. De rioolwateroverstort bij Meppen had een berg-bezinking-leiding gekregen om de vuillast te reduceren. Het bleef echter een probleem dat deze overstort in de bovenstroom van het systeem uitkomt via de Broekstroom. De rioolwateroverstort van Gees zal pas minder vaak in werking treden door het afkoppelen van het verharde oppervlak. Het verwachte effect is dat door een dalende overstortfrequentie bij Gees de belasting gereduceerd kan worden met circa $18 \%$ (Werkgroep Geeserstroom 2004). In de Boswachterij Gees worden sinds 2004 vernattingsmaatregelen uitgevoerd, deze kunnen een positief effect hebben op de kweldruk in het beekdal. 


\subsection{Herinrichtingsmaatregelen}

Het gehele stroomgebied van de Geeserstroom is in 2005 en begin 2006 opnieuw ingericht. Om het streefbeeld van een natuurlijk beekdal te benaderen was herstel nodig van:

- $\quad$ het grondwaterniveau en grondwaterstromingen;

- $\quad$ de natuurlijke beekhydrologie en -morfologie;

- de reductie van de nutriëntenbelasting.

Om dit te bereiken zijn de volgende ingrepen gepland en uitgevoerd (Werkgroep Geeserstroom 2004) (figuur 2.6):

- $\quad$ Bijna alle watergangen van het hoofdafwateringssysteem zijn gedempt. De beek ten oosten van de Klinkenberg is ook gedempt, het water zal voortaan via het maaiveld afstromen naar de hoofdstroom.

- Het is de bedoeling dat het voedselrijke water uit de landbouwgebieden zoveel mogelijk wordt omgeleid. Het gemaal Bollema watert echter nog steeds af op de beek.

- In de velden bovenstrooms, Mepper Hooilanden, Koemarsen en De Marsen, is in de laagste delen een slenk gegraven om het water af te voeren.

- $\quad$ Een beek is opnieuw gegraven (vanaf De Marsen tot bij de Luibroekma) als een zwak meanderende (bovenstroom) tot meanderende (benedenstroom) geul in laagste delen van het maaiveld.

- $\quad$ Ten oosten van het heideveld de Hooge Stoep is een slenk gegraven voor de afwatering.

- De zijtak uit Gees is in de Oude Maden voorzien van een smal ondiep profiel dat licht kronkelt.

- $\quad$ Om een geleidelijke overgang van hoge waterstanden in het natuurgebied naar lage waterstanden in het omringende landbouwgebied te overbruggen, is er een stuw met een vistrap geïnstalleerd en in een strook tussen de Roonboomdijk en het landbouwgebied komt een systeem met sloten als bufferzone.

- Het beekdal heeft benedenstrooms weer een open karakter (conform het karakter van rond 1900) door het kappen van de aangeplante bossen uit de jaren '70.

- Het landschap is verfraaid door het herstellen en opnieuw aanleggen van de houtsingels en -wallen bovenstrooms en het plaatsen van landelijke hekwerken. Deze maatregel is echter niet uitgevoerd.

De voorspelling aan de hand van de eerdere beschrijvingen en de te nemen herstelmaatregelen zijn dat er bovenstrooms (de bovenste velden) een kwelwater gevoed systeem ontstaat, dat periodiek droog kan vallen. De stoomsnelheid zal matig tot gering zijn. In de middenloop zal het water bestaan uit kwelwater en de Broekstroom (afvoer van overstort Meppen), hierdoor kan de waterkwaliteit slechter zijn. De stroomsnelheid zal gering zijn en het systeem zal niet droogvallen, maar zal wel grote peilfluctuaties kennen. De benedenloop zal een iets betere waterkwaliteit hebben door de toevoer van kwelwater en de zijtak vanuit uit Gees (indien afgekoppeld van de overstort). De beek heeft benedenstrooms een grote inundatievlakte en de stroomsnelheid is laag. 


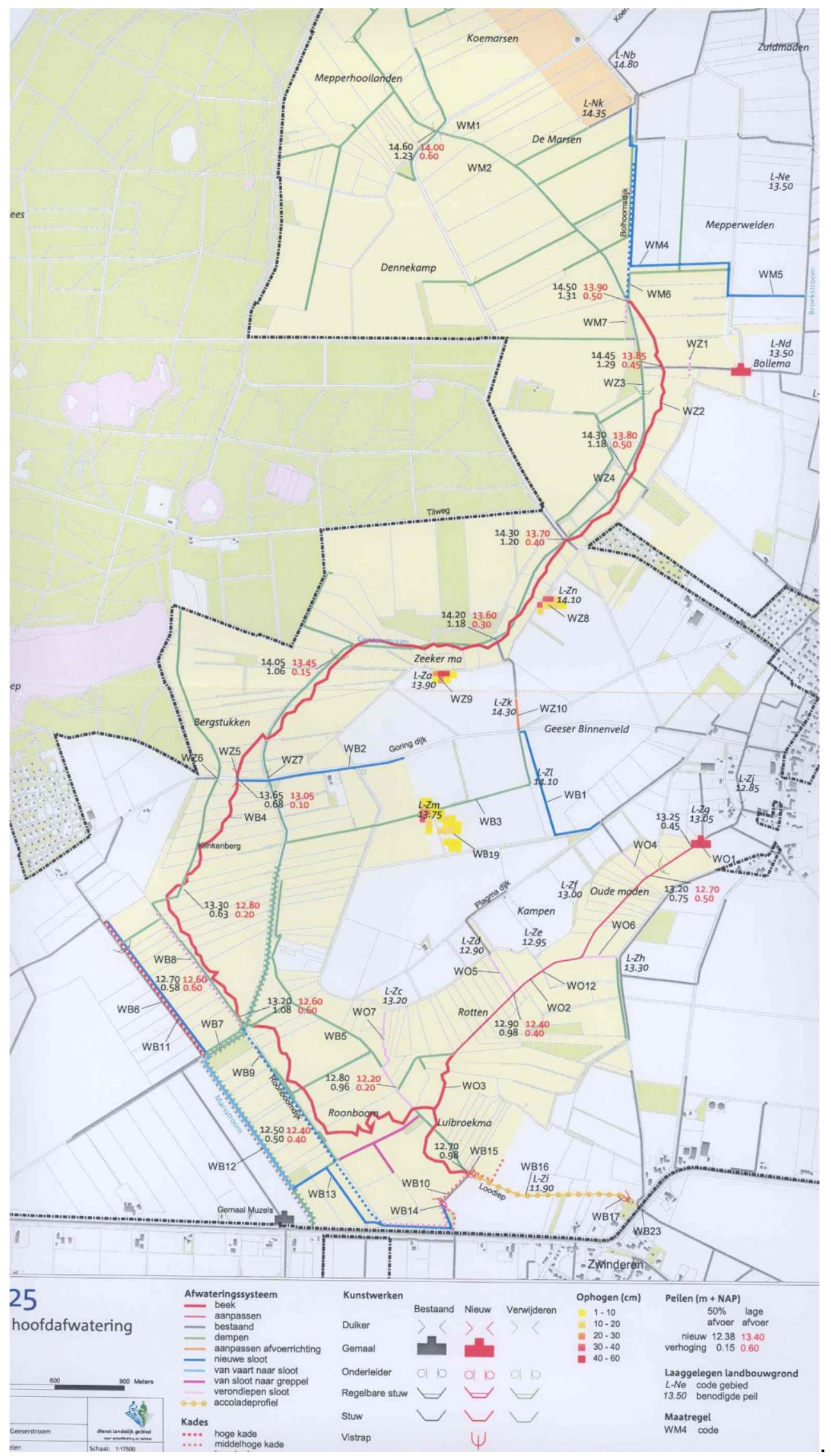

Figuur 2.6 De maatregelenkaart van de Geeserstroom en de waterstromen in de situatie na herinrichting (Werkgroep Geeserstroom 2004). 


\subsection{Toestand en processen na de herinrichting}

\section{Huidige waterhuishouding}

In de huidige situatie is de dichtheid aan waterlopen sterk afgenomen. De Geeserstroom bestaat alleen nog uit een hoofdwatergang (figuur 2.7). De zijstroom vanaf Gees heeft nog wel enkele zijsloten die daarop afwateren. De hoofdstroom volgt het laagste punt in het dal, behalve bij de Goringdijk waar vanwege kabels en leidingen een hoger gelegen traject is aangelegd.

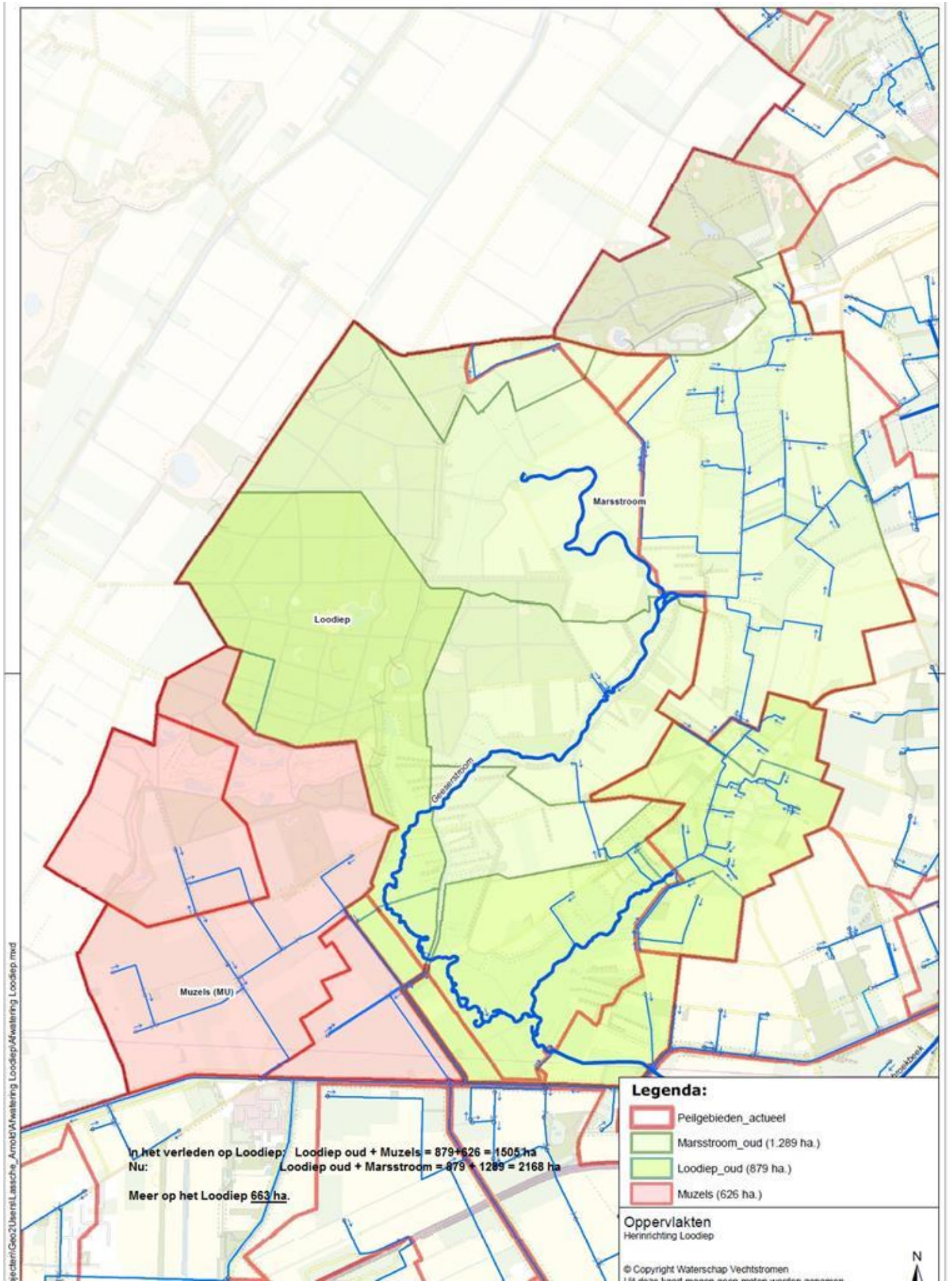

Figuur 2.7 De huidige watergangen van de Geeserstroom. 
Door het uitgraven van de slenk in de Mepper Hooilanden is daar een plas ontstaan. Mede door de drempel onder de Koemarserdijk is een plas ontstaan met een diepte van circa 70 $\mathrm{cm}$. Het bovenste beekgedeelte tussen de plas en de inlaat van gemaal Bollema valt jaarlijks droog.

De inlaat van gemaal Bollema draagt in belangrijke mate bij aan de afvoer van de beek. Aan de zuidoostzijde van de Boswachterij Gees komt relatief veel kwel in het beekdal.

\section{Huidige grond- en oppervlaktewater kwaliteit}

Analyse van de samenstelling van het grondwater in twee raaien bovenstrooms in de Mepper Hooilanden (figuur 2.8) en benedenstrooms (figuur 2.9) in de BergstukkenRoonboom) laat zien dat er een duidelijke variatie in grondwatersamenstelling in het landschap aanwezig is. De infiltratiegebieden laten mineraalarm en zuur grondwater zien en de kwelgebieden mineraalrijker, basisch en ijzerrijk grondwater. De concentraties van ammonium en vooral nitraat zijn zeer laag.
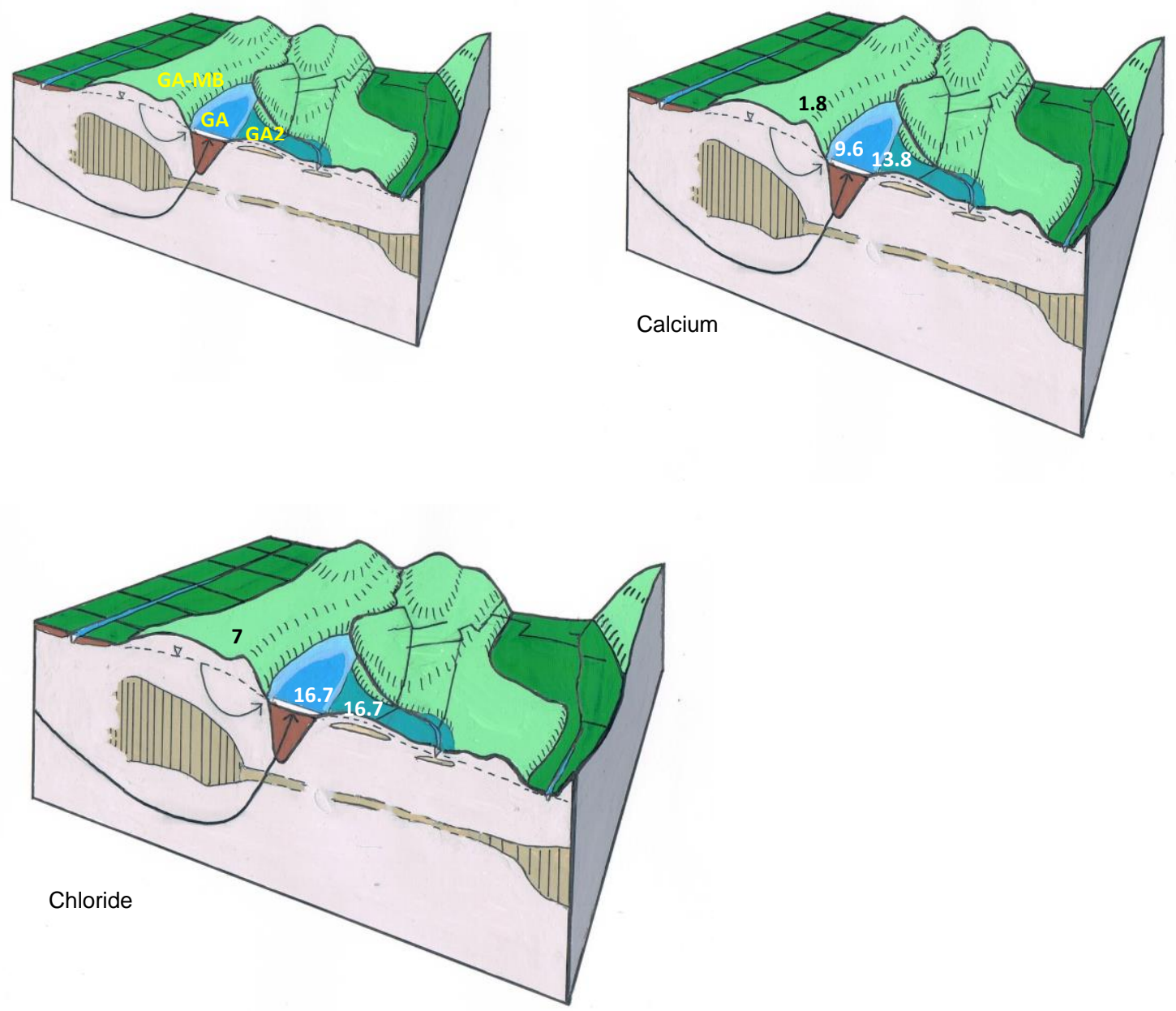

Figuur 2.8 Concentraties van calcium en chloride (mg/l) in het grondwater (mei 2016) in een raai in de Mepper Hooilanden. Lichtgroen zijn de minerale gronden met daaronder nog restanten van keileem. In het beekdal zelf is de keileem in het verleden weg geërodeerd. Donkergroen zijn bemeste graslanden. De codes $G A-M B$, GA en GA2 verwijzen naar de respectievelijke peilbuizen (zie Tabel 2.1). 
Echter de absolute concentraties zijn een stuk lager dan analyses die voor de ingrepen zijn genomen (Werkgroep Geeserstroom 2004). Dit wijst erop dat de invloed van het neerslagwater in de bovenste bodemlagen (tot $1-2 m-m v$ ) sterk is toegenomen.

Waarschijnlijk zullen de waarden in de kwelgebieden toenemen na een langdurige droge periode, maar een voorlopige conclusie is dat de hoge waterstanden, de toestroming van basenrijk grondwater bemoeilijkt.

De analyses die in oktober 1986 en juni 1987 zijn uitgevoerd laten zien dat op diverse plaatsen in het beekdal kalkrijk grondwater (70-80 mg calcium per liter) aanwezig is op een diepte van 5-6 meter -mv. Dit werd geïnterpreteerd als toestroming van (sub-)regionaal grondwater. Dit lijkt ons een juiste interpretatie. Ondiepe buizen op 1-2 meter diepte lieten nog hogere waarden zien (calcium> $100 \mathrm{mg} / \mathrm{l}$ ). De Werkgroep Geeserstroom maakt geen onderscheid tussen kalkrijk (tot $80 \mathrm{mg} / \mathrm{l}$ en zeer kalkrijk water (> $100 \mathrm{mg} / \mathrm{l}$ ). Wij interpreteren de aanwezigheid van dit zeer kalkrijke grondwater als het optreden van secundaire oplossing van kalkhoudend zand in een infiltratiesituatie. Sommige delen van het onderzoeksgebied (bijvoorbeeld de Mepper Hooilanden zijn altijd heel nat geweest en ontkalking heeft hier maar gering plaatsgevonden. Bij het in de 50er jaren in zulke gebieden aanleggen van drainagesloten kan het infiltrerende neerslagwater in diepere lagen (1-2m -mv) veel kalk oplossen (zie bijvoorbeeld Grootjans et al. 2004).
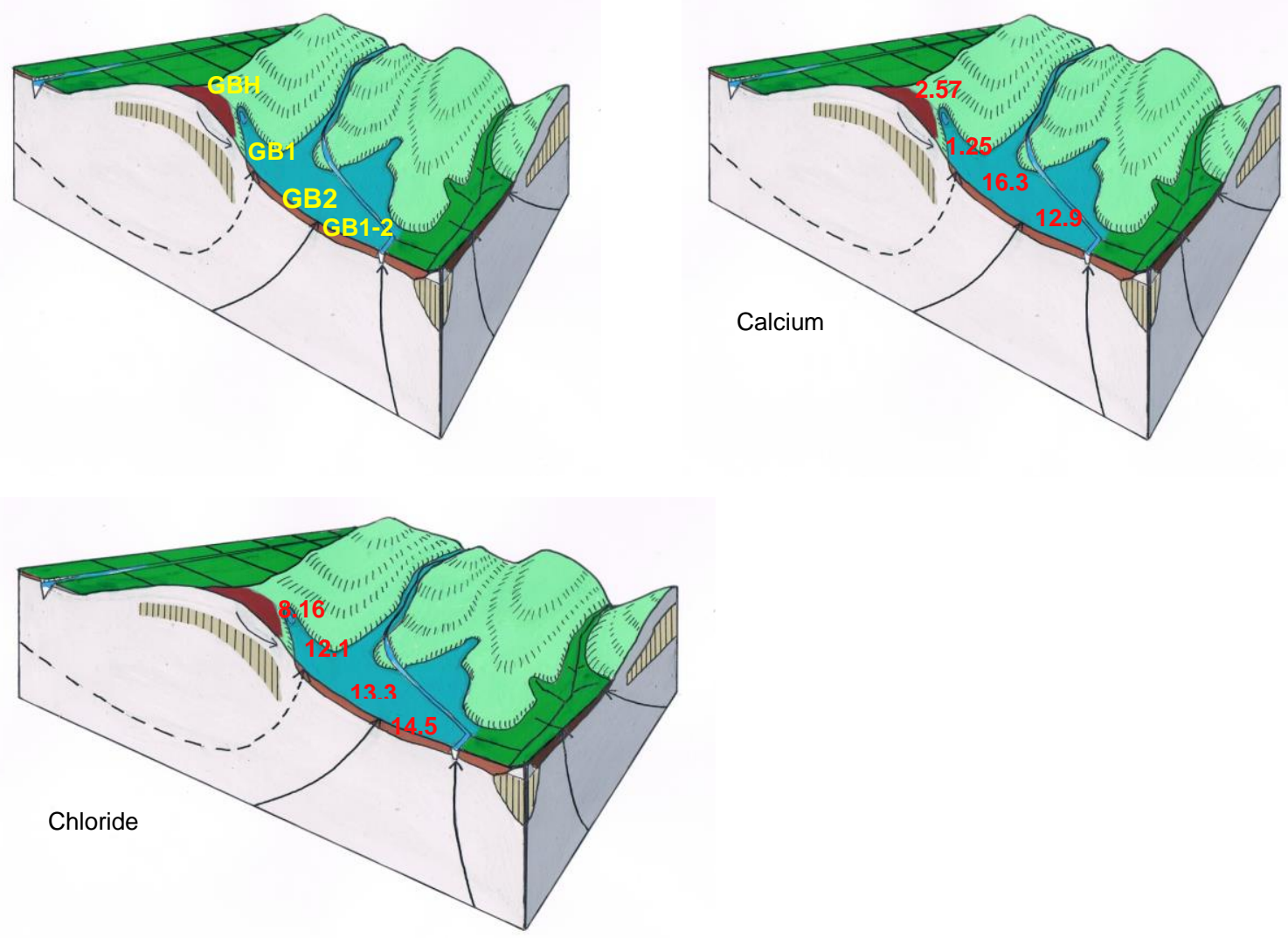

Figuur 2.9 Concentraties van calcium en chloride (mg/l) in het grondwater (mei 2016) in een raai van de Bergstukken naar Roonboom. Lichtgroen zijn de minerale gronden met daaronder nog restanten van keileem. In het beekdal zelf is de keileem in het verleden weg geërodeerd. Donkergroen zijn bemeste graslanden. De codes GBH, GB1, GB2 en GB1-2 verwijzen naar de respectievelijke peilbuizen (zie Tabel 2.1). 
Tabel 2.1 Samenstelling van het grondwater (in mg/l) gemeten in mei 2016 in een raai Bovenstrooms (Mepper Hoolanden en (GA-serie) en in een benedenstrooms gebied (Bergstukken- Roonboom; GB-serie).

\begin{tabular}{|l|l|r|r|r|r|r|r|r|}
\hline Parameter & code & GA-MB & GA-1 & GA-2 & GB-H & GB-1 & GB-2 & GB-1-2 \\
\hline $\mathrm{pH}$ & & 4.39 & 6.58 & 6.69 & 5.49 & 5.76 & 6.69 & 6.63 \\
\hline $\mathrm{NO} 3$ & $\mathrm{mg} / \mathrm{l}$ & 0.12 & 0.06 & 0.12 & 0.01 & 0.03 & 0.01 & 0.01 \\
\hline $\mathrm{NH} 4$ & $\mathrm{mg} / \mathrm{l}$ & 1.22 & 1.66 & 4.16 & 0.22 & 0.17 & 0.11 & 0.11 \\
\hline $\mathrm{Cl}$ & $\mathrm{mg} / \mathrm{l}$ & 6.95 & 16.72 & 16.67 & 8.16 & 12.11 & 14.54 & 13.27 \\
\hline $\mathrm{Al}$ & $\mathrm{mg} / \mathrm{l}$ & 36.84 & 0.32 & 6.35 & 0.39 & 1.26 & 0.18 & 0.57 \\
\hline $\mathrm{Ca}$ & $\mathrm{mg} / \mathrm{l}$ & 1.83 & 9.62 & 13.76 & 2.57 & 1.25 & 12.94 & 16.29 \\
\hline $\mathrm{Fe}$ & $\mathrm{mg} / \mathrm{l}$ & 1.39 & 20.07 & 1.45 & 0.11 & 0.08 & 1.19 & 8.07 \\
\hline $\mathrm{K}$ & $\mathrm{mg} / \mathrm{l}$ & 1.49 & 2.37 & 4.40 & 1.72 & 3.40 & 1.33 & 2.48 \\
\hline $\mathrm{Mg}$ & $\mathrm{mg} / \mathrm{l}$ & 2.40 & 6.83 & 9.37 & 0.91 & 0.72 & 4.12 & 5.62 \\
\hline $\mathrm{Mn}$ & $\mathrm{mg} / \mathrm{l}$ & 0.02 & 0.48 & 0.13 & 0.04 & 0.00 & 0.02 & 0.19 \\
\hline $\mathrm{Na}$ & $\mathrm{mg} / \mathrm{l}$ & 14.94 & 27.64 & 18.38 & 10.26 & 21.11 & 17.92 & 21.85 \\
\hline $\mathrm{P}$ & $\mathrm{mg} / \mathrm{l}$ & 0.44 & 1.01 & 0.12 & 0.03 & 0.03 & 0.06 & 0.04 \\
\hline $\mathrm{S}$ & $\mathrm{mg} / \mathrm{l}$ & 1.26 & 14.79 & 3.73 & 1.90 & 3.46 & 1.23 & 1.35 \\
\hline
\end{tabular}

Voor de concentraties van voedingstoffen als stikstof en fosfaat in het oppervlaktewater zijn de bovenstroomse locatie Tilweg (AGEE50) en de benedenstroomse locatie Roonboom (AGEE86) gebruikt (zie figuur 2.1). Het verloop in het stikstofgehalte laat relatief lage ammoniumgehaltes, wisselende nitraatgehaltes en een Kjehldalstikstof rond de $1.2 \mathrm{mg} / \mathrm{l}$ zien bovenstrooms terwijl dit laatste stijgt naar circa $2.0 \mathrm{mg} / \mathrm{l}$ benedenstrooms (figuur 2.10). Het ortho-fosfaat en totaal fosfaatgehalte is bovenstrooms lager dan benedenstrooms. Totaal fosfaat schommelt rond de $0.13 \mathrm{mgP} / \mathrm{l}$ bovenstrooms en de $0.23 \mathrm{mgP} / \mathrm{l}$ benedenstrooms (figuur 2.11). De benedenstroomse toename van stikstof en fosfaat hangt mogelijk samen met uitspoeling van nutriënten uit de voormalige en nu frequent geïnundeerde landbouwgronden. Een voorbeeld van de nutriëntenbalans voor fosfor $(P)$ en stikstof $(N)$ in het beekdal Dwarsdiep, een beek met vergelijkbare nutriëntengehalten als de Geeserstroom (de Haan 2014):

In

Uit

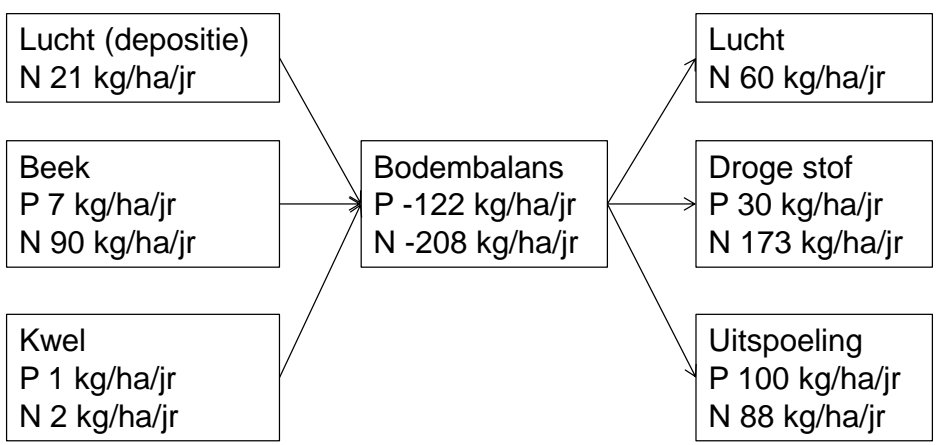

De voedingsstoffengehalten duiden op hypertrofe, $\alpha$-mesosaprobe omstandigheden in het beekwater. De macro-ionengehalten zijn boven- en benedenstrooms redelijk vergelijkbaar (figuur 2.12). 


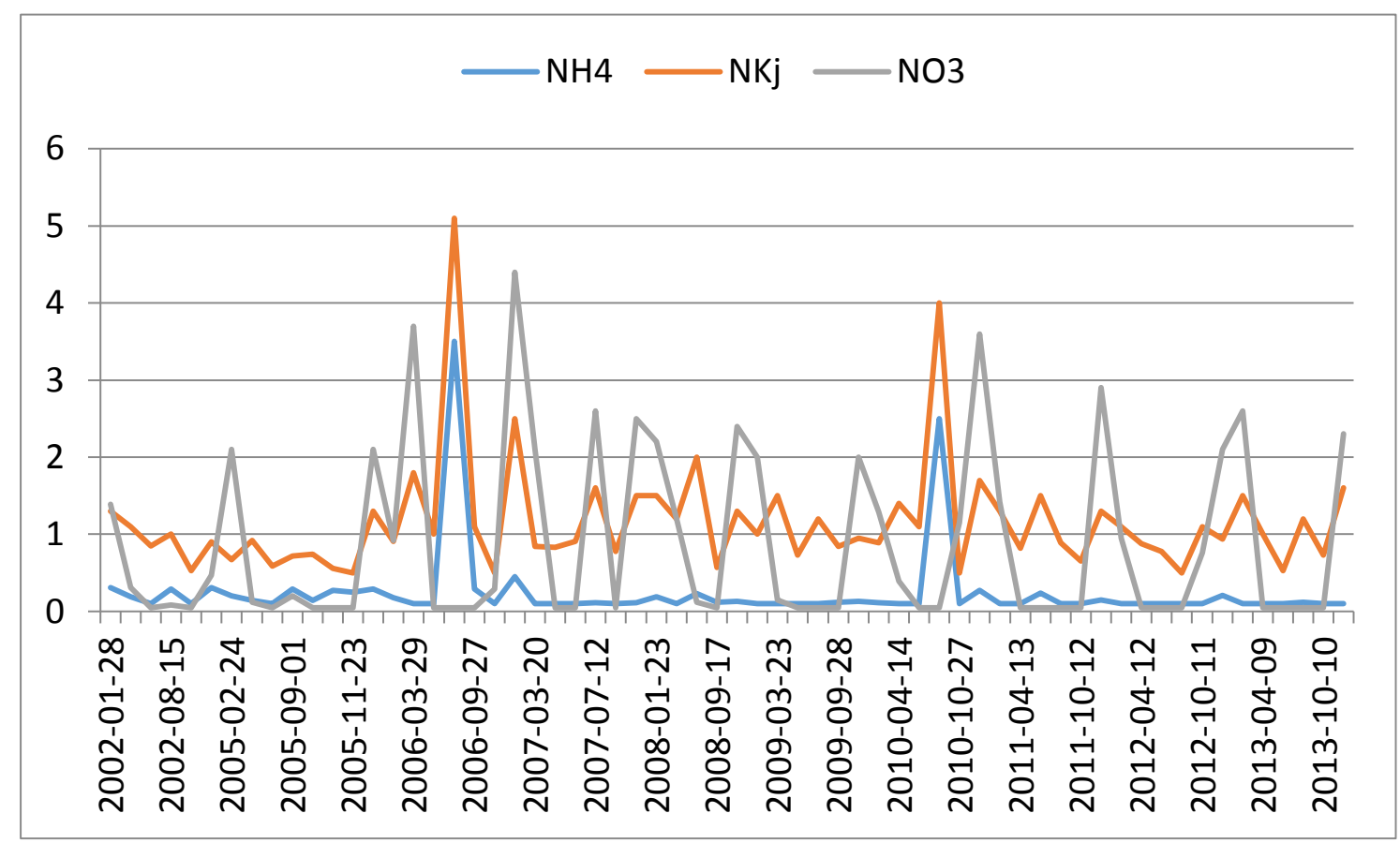

A

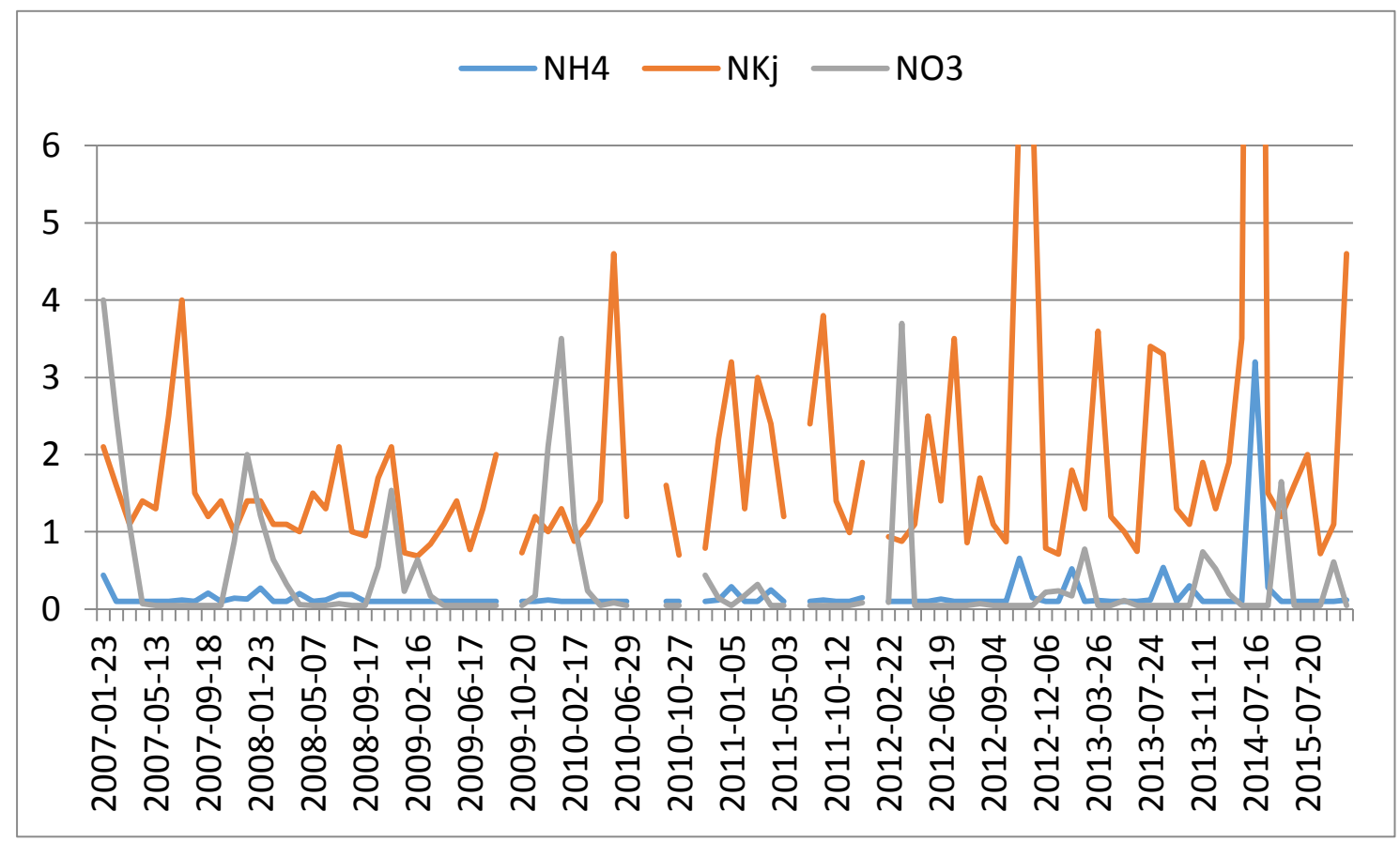

B

Figuur 2.10 Het verloop van het ammonium, nitraat en Kjehldalstikstof (in mg/l) voor de locaties AGEE50 bovenstrooms ( $A$ ) en AGEE86 benedenstrooms (B). (Voor ligging locaties zie figuur 2.1) 


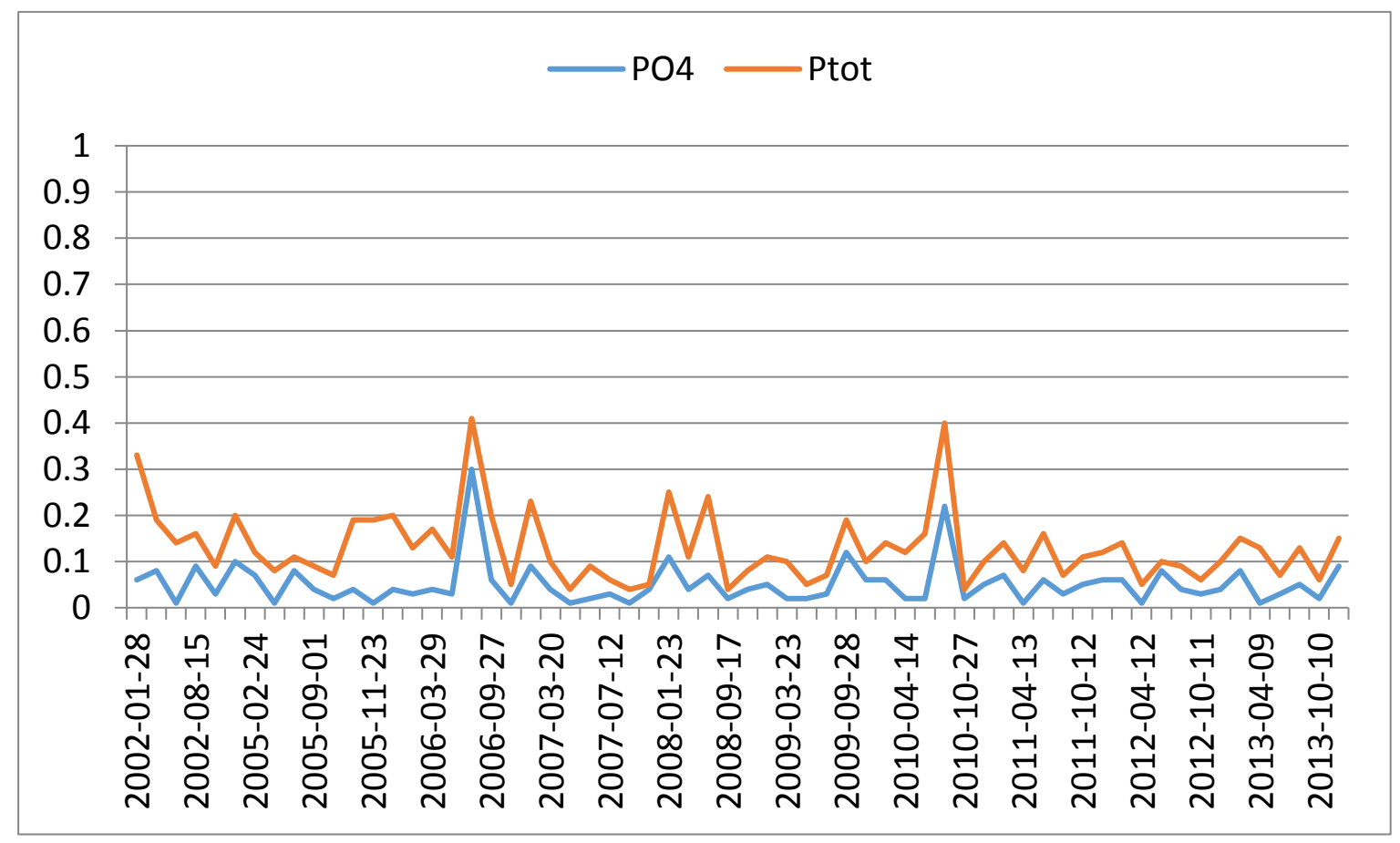

A

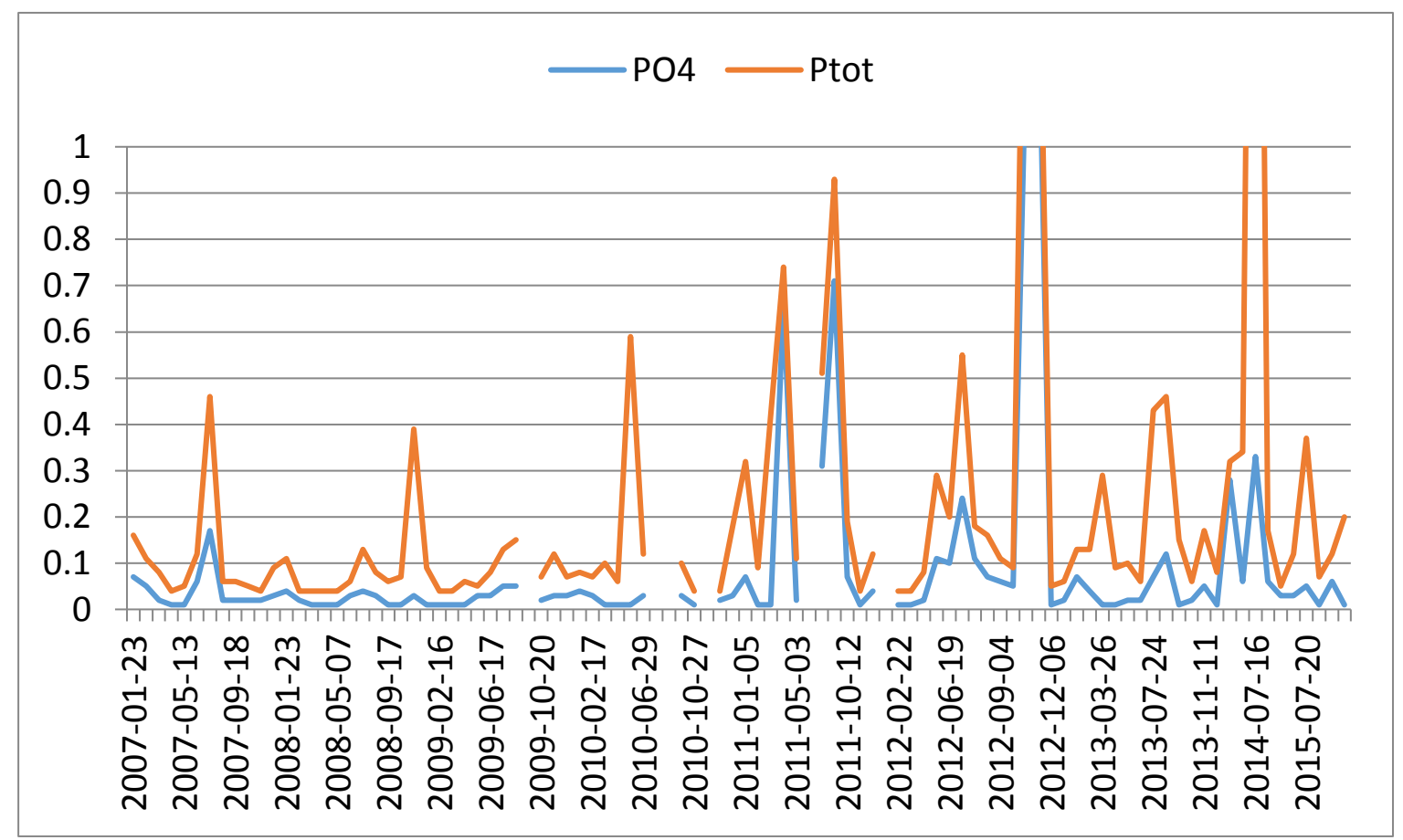

B

Figuur 2.11 Het verloop van het ortho-fosfaat en totaal fosfaatgehalte (in $\mathrm{mg} / \mathrm{l})$ voor de locaties AGEE50 bovenstrooms ( $A$ ) en AGEE86 benedenstrooms (B). (Voor ligging locaties zie figuur 2.1) 


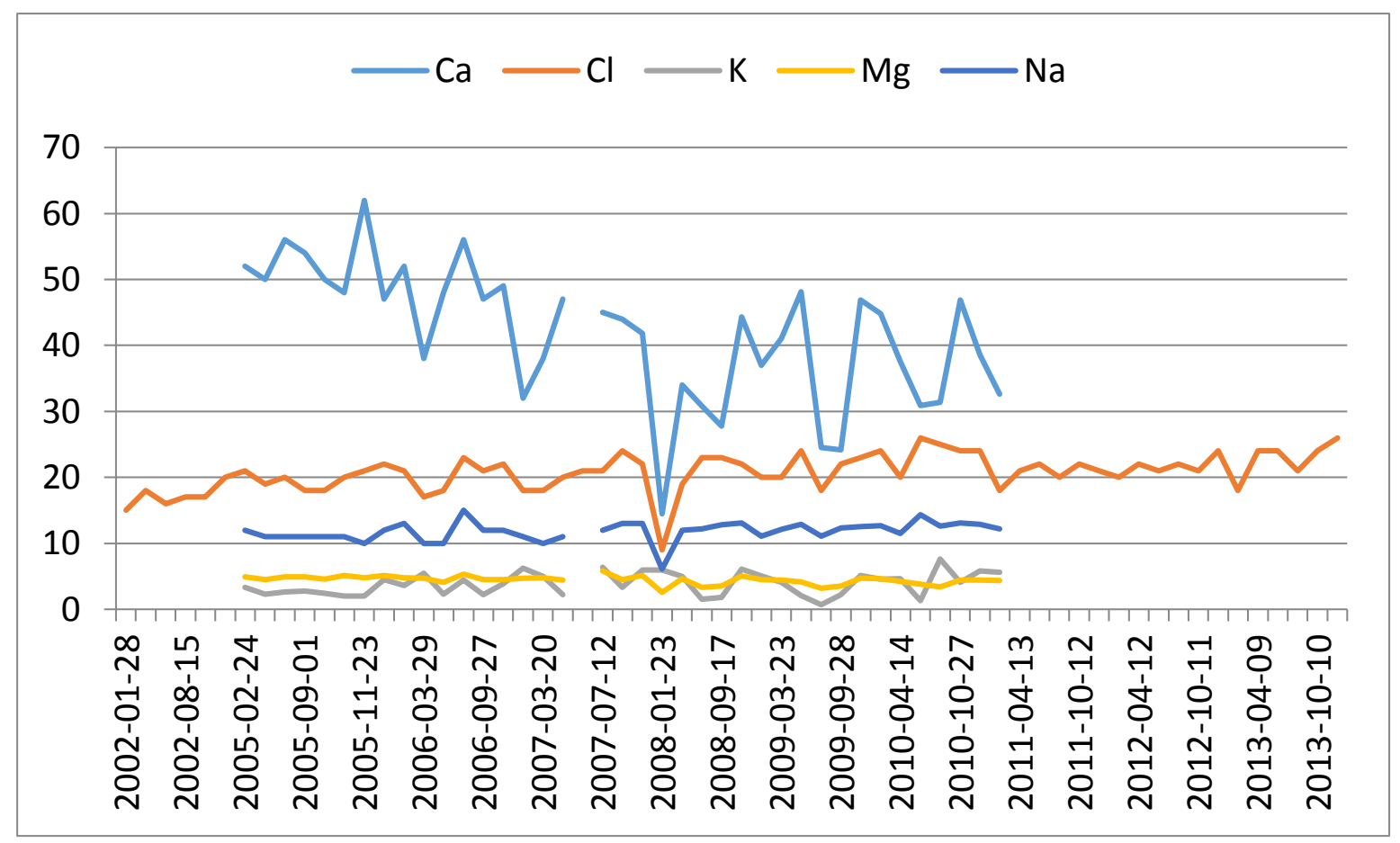

A

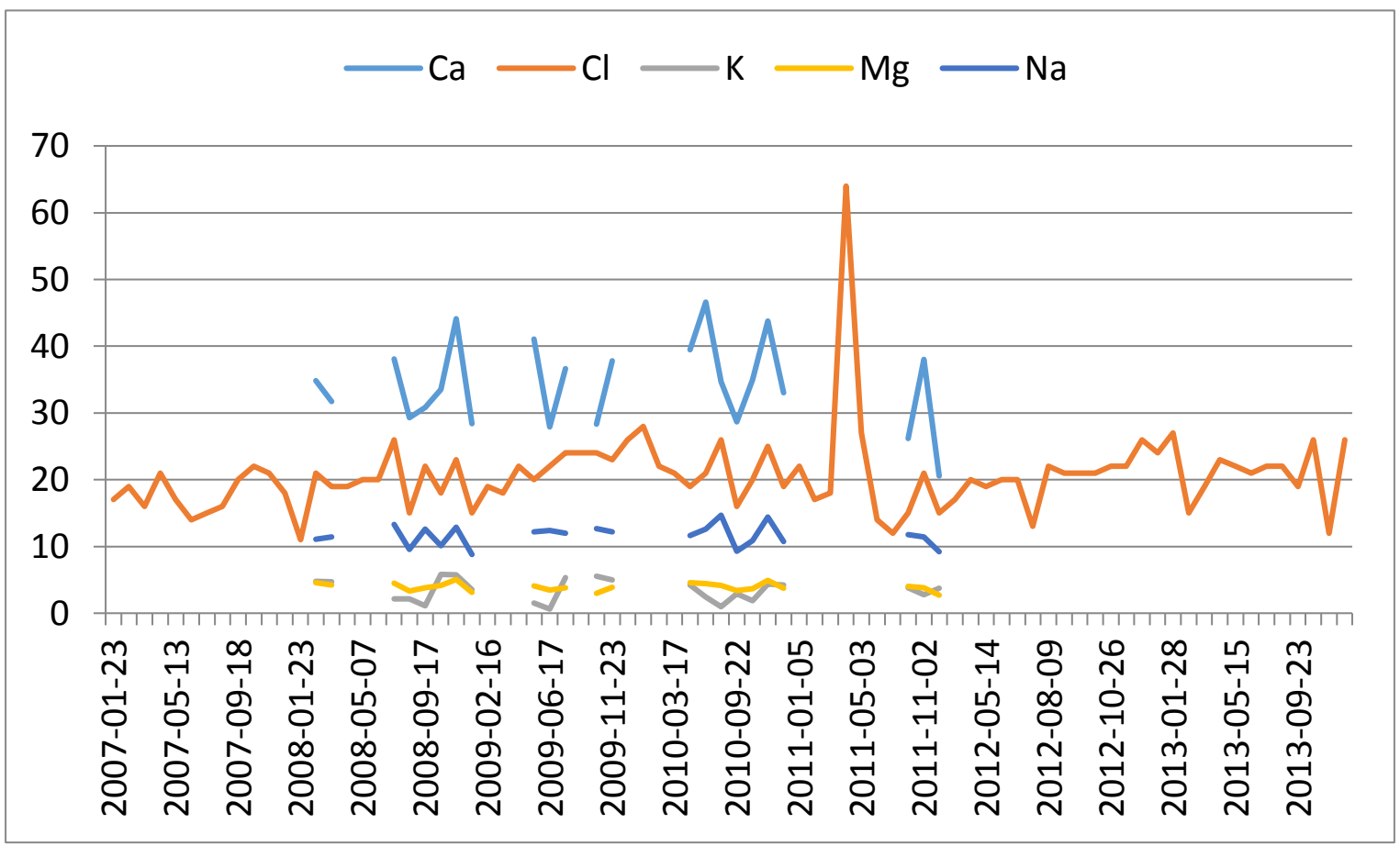

B

Figuur 2.12 Het verloop van het calcium-, chloride-, kalium, magnesium en natriumgehalte (in $\mathrm{mg} / \mathrm{ll}$ ) voor de locaties AGEE50 bovenstrooms ( $A$ ) en AGEE86 benedenstrooms (B). (Voor ligging locaties zie figuur 2.1) 


\section{Huidige flora en fauna}

\section{Beekdalvegetatie}

In 1999 en 2008 (figuur 2.13) zijn door Altenburg \& Wymenga vegetatiekarteringen van de Geeserstroom uitgevoerd (Groeneweg 2000, van der Veen 2009). De vegetaties zijn tussen 1999 en 2008 veranderd door vier veranderingen: plaggen, beekinundatie, verschralingsbeheer en versterkte lokale kwel. Hierdoor is de differentiatie in vegetatietypen in het gebied toegenomen. Er zijn ontwikkelingen zichtbaar in de richting van regenwaterafhankelijke vegetaties in het bovenloopgebied, grondwatergebufferde vegetaties in de kop en langs de bovenloop en Dotterbloemhooilanden direct langs de beek. Meer benedenstrooms zijn in 2008 overstromingsgraslanden met Rietgrasbegroeiingen te vinden mede als gevolg van de hogere voedselrijkdom.

\section{Macrofyten}

Uit een multivariate analyse uitgevoerd op de opnames van 2002, 2005 en 2007 bleek dat er niet veel verschil was in de macrofytensamenstelling tussen de jaren en de verschillende locaties in de Geeserstroom (Didderen et al. 2008). Alleen week het 'bron'gebied af van alle andere locaties omdat hier het aantal plantensoorten laag was en waternavel Hydrocotyle vulgaris en knolrus Juncus bulbosus voorkwamen. Daarnaast was er een gering verschil tussen benedenstroomse monsters van voor en na de herinrichting. Voor de herinrichting kwamen soorten voor als gekroesd fonteinkruid Potamogeton crispus, doorgroeid fonteinkruid $P$. perfoliatus, waterzuring Rumex hydrolapathum, grote watereppe Sium latifolium, gele lis Iris pseudacorus, gele plomp Nuphar lutea, slanke waterkers Rorippa microphylla, kleine egelskop Sparganium emersum, pijlkruid Sagittaria sagittifolia en liesgras Glyceria maxima (allen waterplanten kenmerkend voor een stilstaande en voedselrijke situatie), die na de herinrichting (waarschijnlijk tijdelijk) waren verdwenen. Er was nog geen duidelijk positief effect van de herinrichting zichtbaar en waterplanten kenmerkend voor stromend water waren nog niet teruggekeerd.

\section{Macrofauna}

In 2012 is een analyse verricht op de macrofauna verzameld over de periode 2004-2011 waaruit bleek dat de rheofiele (stromingsminnende) soorten amper een rol in het systeem van de Geeserstroom spelen na herinrichting (Verdonschot \& Verdonschot 2012). De indicatie voor rheofilie stijgt niet in de loop van de tijd en in de bovenloop nam de waarde zelfs licht af. Dit beeld past bij de waarneming dat na herinrichting grote oppervlaktes stagnante delen op de verschillende monsterlocaties in de beek aanwezig zijn en dat het smalle beekloopje dat zich een weg baant door de vegetatie weinig bijdraagt aan het beekkarakter. Er heeft ook nog geen sterke kolonisatie van stromingsminnende soorten plaatsgevonden en er is geen sprake van een sterke populatiegroei van de al aanwezige beeksoorten. Een kleine uitzondering vormen de enkele jaren waarin een kleine opleving heeft plaatsgevonden, wat af te leiden is uit het aandeel passieve filtreerders in de macrofaunagemeenschap. Deze pieken zijn het gevolg van abundantiepieken van bijvoorbeeld Simulium en Dixidae. De oorzaak hiervan was waarschijnlijk een periode met hogere afvoer. 


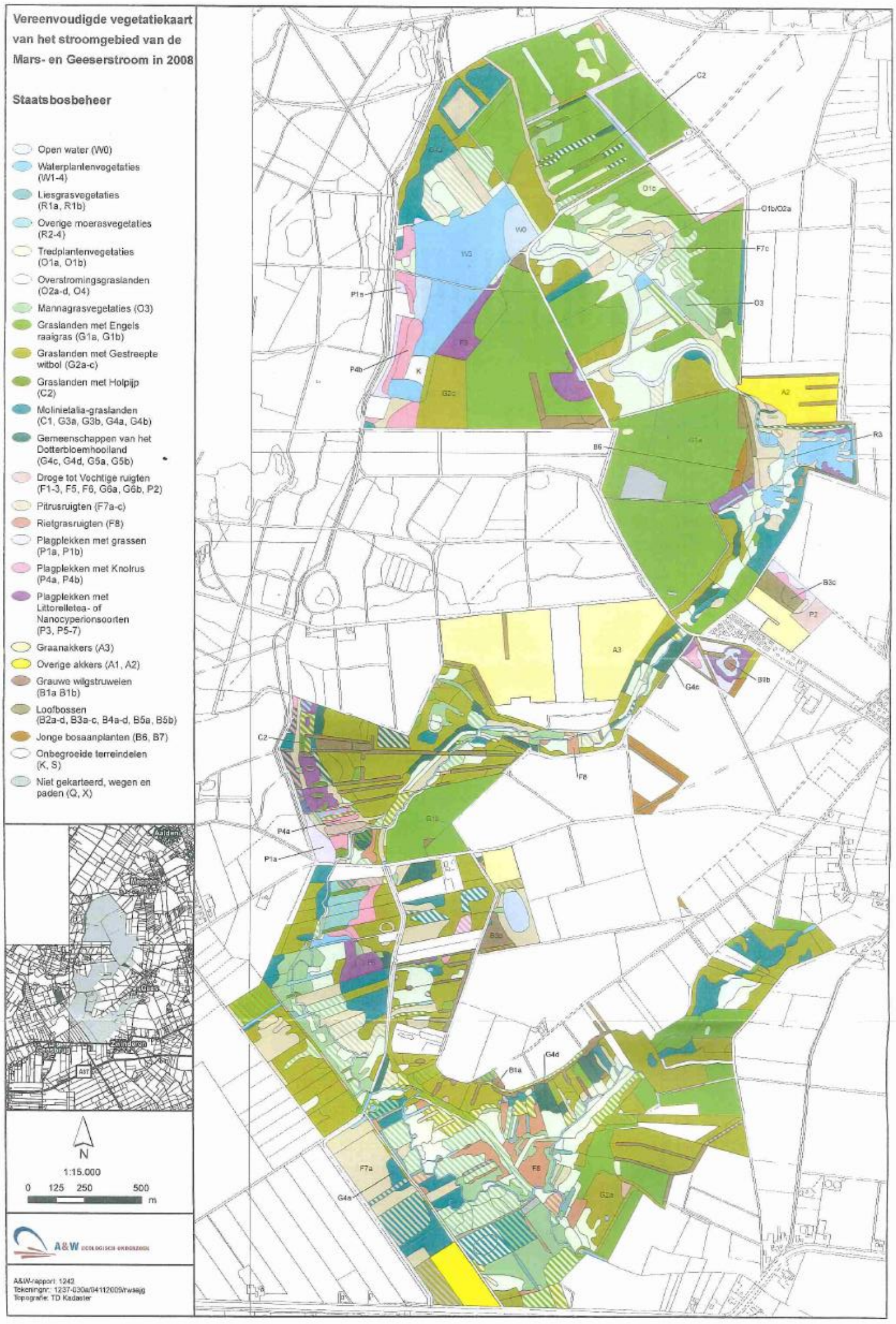

Figuur 2.13 Vereenvoudigde vegetatiekaart van het stroomgebied van de Geeserstroom (van der Veen 2009). 
Opvallend is dat ook het aandeel macrofauna dat typerend is voor kleine plantenrijke stilstaande wateren achterblijft, ondanks de grote hoeveelheid waterplanten in de beek. Waarschijnlijk is het achterblijven van het aandeel van deze taxa het gevolg van de middelmatige tot vrij hoge indicatie voor slib prefererende soorten, in combinatie met de structureel hoge indicatie voor organische belasting. Deze soortengroep wijst op een ophoping van organisch materiaal en daarmee o.a. het optreden van perioden van zuurstofloosheid, wat negatief uitwerkt op zowel rheofiele soorten als de waterplantentaxa. Zorgelijk zijn de hoge waarden van de saliniteit-index die op sommige locaties zijn gevonden. De hoge waarden duiden op plotselinge verstoringen binnen de levensgemeenschap. Wisselingen in de ionen-balans worden waarschijnlijk veroorzaakt door verschuivingen in de herkomst van het beekwater (oppervlakkige afspoeling/inlaat t.o.v. kwel). Het aantal kokerjuffergenera kent op de meeste locaties opvallende pieken en dalen. Hier is geen duidelijk patroon in te onderscheiden. Deze variabiliteit kan een drietal oorzaken hebben: 1) wisselingen in milieuomstandigheden, 2) het toevallig vestigen van soorten die geen duurzame populaties kunnen opbouwen, en/of 3) een bemonsteringseffect. Op één locatie is het aantal kokerjuffergenera na herinrichting duidelijk afgenomen; een situatie die zich tot nu toe niet heeft hersteld.

De herinrichting van de Geeserstroom heeft tot 2008 niet geleid tot het ontstaan van een beekecosysteem met een hoge ecologische kwaliteit, gekarakteriseerd door een hoge score voor rheofilie, een hoog aantal kokerjuffergenera en haften- plus steenvliegengenera en een hoog aandeel passieve filtreerders in de levensgemeenschap. De Geeserstroom had op dat moment het karakter van een organisch rijk (belast) stilstaand water.

\section{$\underline{\text { Vissen }}$}

Vlak na de herinrichting is in 2005 is met elektro-handvissen de Geeserstroom bevist. Er zijn soorten uit verschillende gildes verzameld:

- $\quad$ eurytoop (baars, blankvoorn, kolblei, snoek)

De soorten uit deze groep komen algemeen voor en stellen weinig eisen aan hun leefmilieu (generalisten). Enige plantengroei is wel nodig. De snoek heeft wel helder water nodig. Te lage zuurstofgehalten leiden tot sterfte.

- limnofiel (vetje, zeelt)

De soorten uit deze groep leven in ondiepe platenrijke wateren. Het vetje houdt wel van enige stroming.

Samenvattend duiden de gevonden soorten niet op een rheofiel systeem.

\section{$\underline{\text { Vogels }}$}

In 2015 is de Geeserstroom uitgebreid geïnventariseerd op de aanwezigheid van broedvogels (A.J. van Dijk en J. Kleine, Drentse Vogels 29-2015: bijlage 3). De inventarisatie leverde 95 broedvogelsoorten en 3077 paren op. Gebaseerd op het aantal territoria blijkt dat de meeste vogels voorkomen in loofbos, gemengd bos en naaldbos (32\%). Moeras- en half open landschap gebonden vogels nemen $8 \%$ en $7 \%$ in. Van de 95 broedvogelsoorten staan maar liefst 23 met in totaal 279 paar op de Rode Lijst van bedreigde soorten (bijlage 4). De broedvogels zijn ingedeeld naar drie typen habitat: water en moeras, open grasland en halfopen grasland met bosjes. Met 30 soorten en 1131 paren vertegenwoordigen water- en moerasvogels ongeveer een derde van de broedvogelstand. Dit habitat neemt ruim de helft van de oppervlakte van het gebied in beslag. Het grote aantal vastgestelde soorten van de Rode Lijst bevestigt het vogelkundige belang van dit gebied in ontwikkeling. 
De ecologische groepen (de ecologische groepen die gebonden zijn aan zoet water naar Sierdsema 1999) binnen de watervogels (Dodaars-groep, Slobeend-groep, Kuifeend-groep, IJsvogel-groep) zijn in het dal van de Geeserstroom met 16 soorten vertegenwoordigd. De aanwezige soorten zijn gerelateerd aan de voedselrijkdom en de hydrologie. De meeste soorten van de Slobeend- en Kuifeend-groep zijn bijvoorbeeld gebonden aan voedselrijk en permanent open water. Typische beeksoorten van de IJsvogel-groep worden in het Geeserstroomdal niet gevonden, wat niet verwonderlijk is gezien de relatief lage stroomsnelheid en daardoor het ontbreken van erosieve kracht die bijvoorbeeld kan zorgen voor het ontstaand van steilwandjes in de buitenbocht van de beekloop.

De moerasvogels (Roerdomp-groep, Rietzanger-groep, Porseleinhoen-groep, Blauwborstgroep) en soorten van natte tot vochtige ruigtes en lage struwelen (Fazant-groep, Rietgorsgroep) zijn met 11 soorten in het Geeserstroomtraject aangetroffen en 8 soorten ruigtevogels. Sommige soorten zijn typisch zoals de snor die gebonden is uitgestrekte rietvegetaties, die langs de Geeserstroom aanwezig zijn. De 10 soorten natte graslandsoorten (Zomertaling-groep, Grutto-groep), passen goed in de diverse typen natte tot vochtige graslanden die hier te vinden zijn.

Amper voorkomend zijn soorten van de Kleine plevier-groep, de soorten in deze systemen van droogvallende onbegroeide randen langs de beekloop. Alleen de naamgever van de groep is gevonden. Soorten van deze ecologische groep horen dan ook vooral bij systemen met meer dynamiek en de daarmee samenhangende morfologische processen die leiden tot het ontstaan van geschikt habitat, zoals de zandbanken en -strandjes in en langs riviertjes en rivieren. Hetzelfde geldt voor soorten van de Buidelmees-groep, behalve de boompieper zijn geen andere soorten van boomgroepen in rietland en rivierbegeleidend bos gevonden. Ook hier speelt het vrijwel ontbreken van geschikt habitat, grote bomen, een belangrijke rol. In het Geeserstroomdal zijn de meeste grote bomen afgestorven na de vernatting van het beekdal.

\section{Huidige trends}

$\mathrm{Na}>10$ jaar na herinrichting van het beekdal van de Geeserstroom wijken een aantal ontwikkelingen af van wat destijds verwacht werd. In het inrichtingsplan werd het volgende streefbeeld geschetst (Werkgroep Geeserstroom 2004):

Hydrologie: De bovenstroomse gebieden Mepper Hooilanden en Marsen en het benedenstroomse gebied Roonboom tot de Verlengde Hoogeveensche Vaart zijn vlak en geschikt om water te bergen op het maaiveld door de afvoer te beperken. De verdroging in de boswachterij Gees en het nieuwe natuurgebied worden opgeheven.

Waterkwaliteit: De totaal-fosfaat en totaal-stikstof concentraties in de beek voldoen mogelijk aan de landelijke streefwaarden. De instroom van water uit bemest gebied werd als probleem onderkend.

Vegetatie: De vegetatie bestaat uit verlandingsvegetaties, later veenvormende vegetaties in de vlakke, kwel ontvangende laagste delen van de Mepper Hooilanden en de noordwest zijde van de Bergstukken. Deze gebieden gaan in een nat-droog gradiënt naar over naar heide. Nat schraalland komt voor in kwel ontvangende gebieden; het noordelijke deel van de Mepper Hooilanden, een deel van de Marsen, het dal ter hoogte van de Bollema, de Zeekerma, een deel van de Bergstukken, Rotten en delen van de Oude Maden. Op de overgang naar de boswachterij komt heide of grasland voor. Riet en grote zeggen vegetaties komen voor in ondiepe slenken door de (Koe-) Marsen, droge en vochtige heide in de twee landschapselementen nabij de Tilweg. Verspreid liggen drie voedselarme veentjes.

Daarnaast komen verder in het gebied rompgemeenschappen van kamgras- en zilverschoongraslanden voor. 
Beekmilieu: De Geeserstroom en de zijbeek door Oude maden zijn zelfregulerende, krap geprofileerde, vrij afstromende beken met bovenstrooms minder en benedenstrooms meer bochten die variatie in substraten opleveren. Piekafvoeren en droogval ontbreken en stroming (gevoed door continue kwel en lokale neerslag) en zuurstof zijn steeds aanwezig. De bovenlopen zijn beschaduwd. Er komen stromingsminnende vissen en macrofauna voor. De oorsprong ligt in de Mepper Hooilanden, Koemarsen en Marsen en heeft het karakter van een diffuus afvoerend systeem met weinig verhang. Vanaf het gebied Bollema tot aan de Goringdijk ontstaat een smalle, ondiepe beek die de laagste delen in het landschap volgt. Het verhang is hier groter. Vanaf de Goringdijk is sprake van een stromende en actief meanderende beek die ieder jaar het dal inundeert. Het verhang is gering en ook dwars op de beek is er weinig variatie in maaiveldhoogte. Af en toe zullen bij extreem hoge regenval grootschalige inundaties optreden. De zijbeek vanaf Gees heeft een klein stroomgebied en voert minder continu af en valt eerder droog. Er is niet gekozen voor een historisch beektracé.

Poelen: Er komt een netwerk van poelen op zo veel mogelijk historische plekken voor. Landschap: Er is een combinatie van:

1) Een gerestaureerd cultuurhistorisch landschap (situatie rond 1900) waarvan de percelering goed zichtbaar is met een half open karakter door een dicht netwerk van goed ontwikkelde singels en wallen:

De tussenliggende graslanden zijn meest bloemrijk (onder meer de Oude Maden, Luibroekma, Rotten, de hogere delen tussen de Rotten en de Goringdijk, het oostelijke deel van het dal even ten noorden van de Goringdijk en het smalle beekdal tot aan de Bolhoornsdijk. Er is een open gebied met hooi- en weilanden waarvan de percelering goed zichtbaar is door greppels of sloten (onder meer de lagere delen ten zuiden van de Goringdijk, inclusief de Roonboom en de strook tussen de Roonboomdijk en het landbouwgebied). Deze openheid zet zich voort in de lage delen ten noordoosten van de Goringdijk.

2) Een landschap waarvan de percelering meest niet meer zichtbaar is:

Er is een open landschap met verlandingsvegetaties, heide, hooiland en begraasde delen (onder meer in de Koemarsen, de Marsen, een deel van de Mepper Hooilanden de Bergstukken). Er is een overgangszone van heide en grasland naar half open struweel met bosopslag en vervolgens naar struweel en bos.

Achteraf zijn de afwijkingen in huidige ontwikkelingen ten opzichte van het streefbeeld niet verrassend. Veel van de ingrepen hadden destijds een experimenteel karakter. Het streven was gericht op een zo natuurlijk mogelijke afstroming van grond- en oppervlaktewater om de verdroging door de op agrarisch gebruik gerichte waterhuishouding van het dal tegen te gaan. Hierbij waren de kansen op maximaal herstel van die waterhuishouding groot, omdat het gebied een omvangrijk en schoon intrekgebied omvat dat bestaat uit een boswachterij met een min of meer natuurlijk grondwaterregime. Momenteel zijn in het gebied verschillende gevolgen van de destijds geïnitieerde processen zichtbaar:

- De Geeserstroom en haar dal hebben zich niet ontwikkeld tot een laaglandbeekbeek maar beginnen steeds meer kenmerken te krijgen van een doorstroom- en beekbegeleidend moeras. Een doorstroommoeras is een mengvorm van moeras en beek en vormt typologisch een overgang tussen stromend en stilstaand water in een dal met een gering verhang en een langzame stroming. 
- De slenk in de geplande Mepper Hooilanden is een te diepe plas geworden waar verlanding slechts mondjesmaat tot ontwikkeling komt maar waar ook ornithologische waarden zijn ontstaan.

- Het traject tussen de Koemarserdijk en de inlaat Bollema is een droogvallend bovenloopje met regelmatig terugstromend water vanuit de bergingsplas achter de inlaat van gemaal Bollema.

- De inlaat van landbouwwater door gemaal Bollema draagt bij aan de eutrofiëring. Plaatselijk aan de westzijde van de nieuwe loop en noordelijk van de Goringdijk maar ook op enkele andere plaatsen is de invloed van voedselarmer grondwater zichtbaar.

- Inundaties die vooral nutriënten mobiliseren wat leidt tot eutrofiëring.

- De vegetatie wordt grotendeels gekenmerkt door gemeenschappen van voedselrijk vochtige tot natte, geïnundeerde grasland- en ruigte/moerasvegetaties.

- De macrofauna en vissen duiden op ondiepe, stagnerende wateren, stromingsminnende soorten ontbreken bijna overal.

- In het dal heeft zich (al dan niet tijdelijk) een zeer soortenrijke moerasvogelgemeenschap gevestigd, waarvoor het gebied als broed- en pleisterplaats zeer geschikt is gebleken. 


\section{Knelpunten en oplossingen}

\subsection{Hydrologie}

Een deel van deze studie is gericht op het oplossen van bestaande hydrologische knelpunten waarmee de problemen bij het landbouwgebied oostelijk van Bollema en in delen van het landbouwgebied grenzend aan het beekdal, zoals zuidoostelijk van Bollema wat direct op de Geeserstroom afwatert, worden opgelost en waarbij de ecologische kwaliteit van het beekdal van de Geeserstroom verbetert en zich een meer of minder groot beekmoeras kan ontwikkelen. Voor nu en in de toekomst is het streven dat een acceptabele, en - in ieder geval op termijn - onderhoudsarme, waterhuishouding ontstaat.

In paragraaf 3.2 wordt een overzicht gegeven van de belangrijkste analyses die tot nu toe zijn uitgevoerd. Aan de hand van bestaande metingen, kaartmateriaal en verslagen is de huidige situatie aanvullend geanalyseerd (paragraaf 3.3). Paragraaf 3.4 beschrijft de aanvullende hydrologische modelberekeningen. Voor vier verschillende plekken in het stroomgebied zijn modellen gemaakt die de actuele hydrologie beschrijven. Dit geeft inzicht in de weerstanden die de (grond)waterstroming ondervinden. In paragraaf 3.5 is de analyse van de meetgegevens samen met basisinformatie en de keileemkaart vertaald naar voorstellen om de waterhuishouding te verbeteren. Er zijn daarbij waar mogelijk onderhoudsarme maatregelen aangedragen. In paragraaf 3.6 zijn ter verificatie vier hydrologische modellen doorgerekend voor de 'nieuwe' situatie. In paragraaf 3.7 staan de aanbevelingen t.a.v. het oplossen van de hydrologische situatie.

Dit hoofdstuk richt zich op het oplossen van de knelpunten in de waterhuishouding. De gegevens die apart van de meetgegevens en eerdere onderzoeksverslagen zijn gebruikt staan in bijlage 1.

\subsection{Bestaande gebiedsanalyses}

In de analyse van november 2011 (Memo aan Gert Meijering en Gerhard Duursema) wordt geconstateerd dat:

- De hoge waterstanden bij de uitstroom van gemaal Bollema en ten noorden hiervan worden veroorzaakt door opstuwing in het systeem. Op dit moment leiden deze waterstanden niet tot onacceptabele wateroverlast. Uit analyse blijkt geen trend van een toename van de maximale grondwaterstanden. Bovendien is in het bemalingsgebied nog berging aanwezig.

- De waterstanden in de Geeserstroom zijn fors hoger dan is voorzien in het oorspronkelijke plan. De belangrijkste oorzaak hiervoor is de beperkte afvoercapaciteit, waarschijnlijk als gevolg van dichte vegetatie. Waar in de planfase de afvoercapaciteit over het maaiveld als onbeperkt is verondersteld, blijkt met name op het traject tussen de Tilweg en het bos van Moret een fors verhang op te treden bij hogere afvoeren.

- Door de hogere waterstanden in de Geeserstroom is er minder ruimte voor berging in het zuidelijk deel van het plangebied. Het verschil tussen de geplande en gerealiseerde waterstand is echter te gering voor een significante afname. Het is waarschijnlijk dat het water dat geknepen wordt niet tot een waterstandsverhoging bovenstrooms van de Roonboomdijk leidt. Verder naar het 
noorden wordt aanzienlijk meer water vastgehouden. Dit resulteert niet in extra berging omdat grote delen bij middelhoge afvoeren al benut worden.

- In samenspraak met het natuurbeheer moet een beheerstrategie vastgesteld worden voor het traject tussen de Tilweg en het bos van Moret. Hoewel op dit moment geen probleem bestaat, kan een gedragen beheerstrategie bijdragen aan zowel de natuurdoelstellingen als aan het voorkómen van mogelijk toekomstige ongewenste situaties.

In mei 2015 is het verloop van het grond- en oppervlaktewater geanalyseerd met het model Menyanthes (nn). De grondwaterstanden in het beekdal zijn na herinrichting van de Geeserstroom 20 tot $40 \mathrm{~cm}$ gestegen. Aan de randen van het beekdal is de stijging van het grondwater wat minder groot $(10$ tot $20 \mathrm{~cm}$ ) dan vlak langs de beek. Het enige meetpunt in landbouwgebied laat een stijging zien van 15 tot $20 \mathrm{~cm}$ sinds de herinrichting. De GHG is hier echter nog $100 \mathrm{~cm}-\mathrm{mv}$ en levert dus geen problemen voor landbouwkundig gebruik. $\mathrm{Er}$ is geen tendens geconstateerd, de verhoging is stabiel.

De oppervlaktewaterpeilen zijn in het gehele beekdal hoger dan in het ontwerp is bedacht. Dit is het geval bij hoge, maar ook bij lage afvoeren. Bij hoog water is vooral het peil bovenstrooms de Hamer van Moret en de Tilweg veel hoger dan het ontwerp $(20$ tot $50 \mathrm{~cm}$ ). Ook bij lage afvoeren is in dit traject het verschil met het ontwerp het grootst. Het water lijkt te blijven "hangen" in dit traject.

In figuur 3.1 staan de verhanglijnen van de Geeserstroom bij hoge en lage afvoeren: Van Bollema tot de Tilweg is er weinig verhang in het peil, daarna neemt het verhang toe. Van Bollema tot de Hamer van Moret is het gemeten peil bij hoge afvoer 20 tot $50 \mathrm{~cm}$ hoger dan in het ontwerp was voorspeld, daarna is het verschil tussen gemeten en ontwerp 5 tot 10 $\mathrm{cm}$. Bij lage afvoer is het gemeten peil over het gehele traject 30 tot $80 \mathrm{~cm}$ hoger dan in het ontwerp.

Tussen 2012 en 2014 zijn geen peilstijgingen bij dezelfde afvoeren te zien. Nb. Dit duidt erop dat de stroming geen toenemende belemmering ondervindt.

De zeer hoge afvoeren leiden niet tot hogere waterstanden. Dit duidt op een toename van de oppervlakkige afvoer door het beekdal. Bij een lage afvoer houdt de vegetatie het water vast.

In mei 2015 heeft een terreinbezoek van medewerkers van Waterschap Vechtstromen en Staatsbosbeheer de volgende constateringen opgeleverd:

- $\quad$ Het peil bij Bollema is gelijk met het peil van de Geeserstroom. Er zitten drempels met duikers met terugslagklep tussen de vijver en de Geeserstroom, zodat water vanuit de Geeserstroom niet de vijver in zou stromen. Deze constructie ligt geheel onder water en heeft dus geen functie meer.

- $\quad$ Voor de duiker onder de Tilweg zit veel begroeiing en de duiker is mogelijk verzand.

- Voor de brug/vlonder bij de Hamer van Moret zit veel begroeiing in de beek. De vlonder en brug liggen laag en vormen over de hele breedte van het beekdal een belemmering voor de doorstroming.

- $\quad$ Het beekdal tussen de Tilweg en de Hamer van Moret heeft een dichte begroeiing en er is een dikke laag slib en zand afgezet in de loop van de jaren.

De laatste drie aandachtspunten zijn in september 2016 verholpen. 


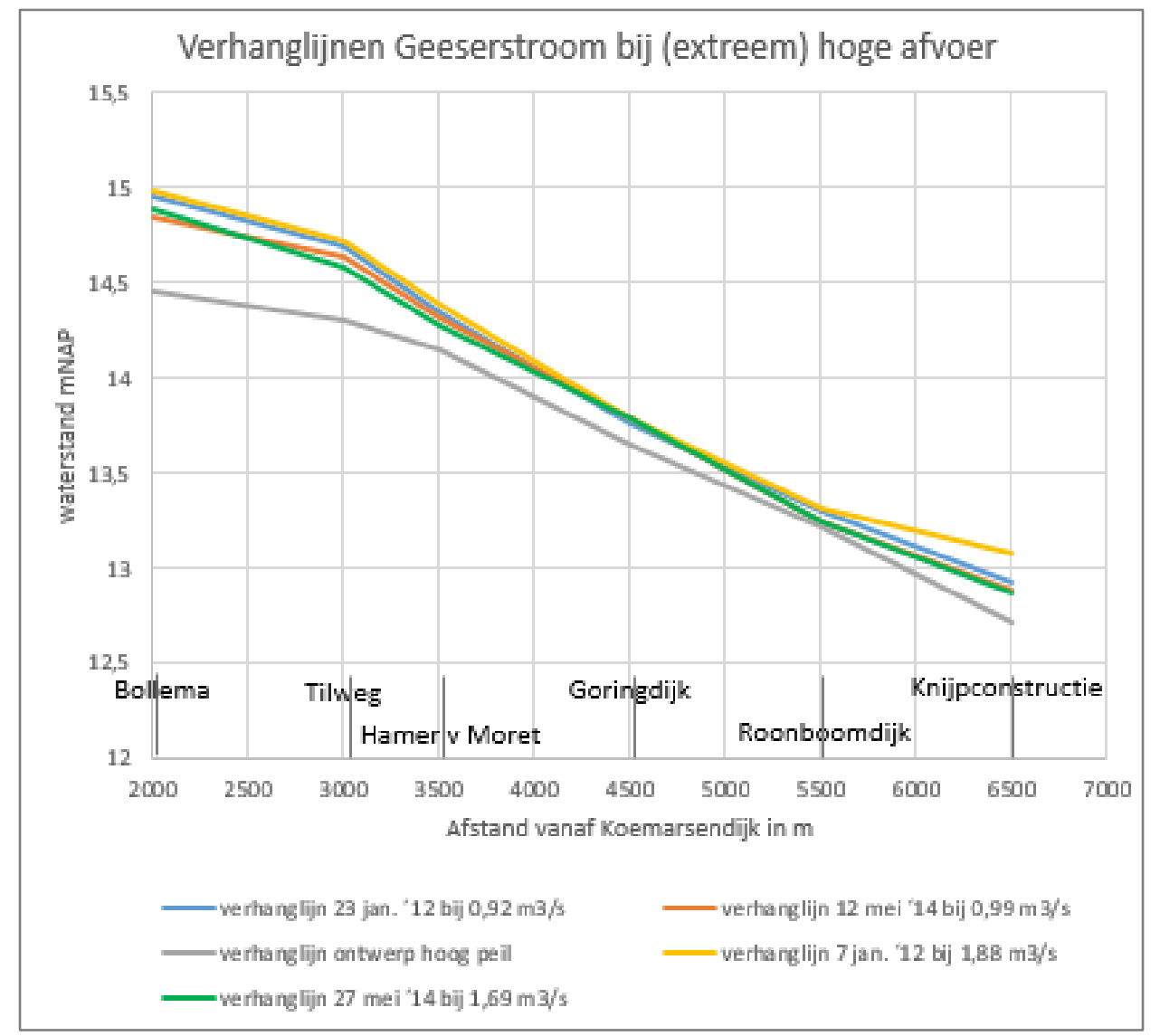

$A$

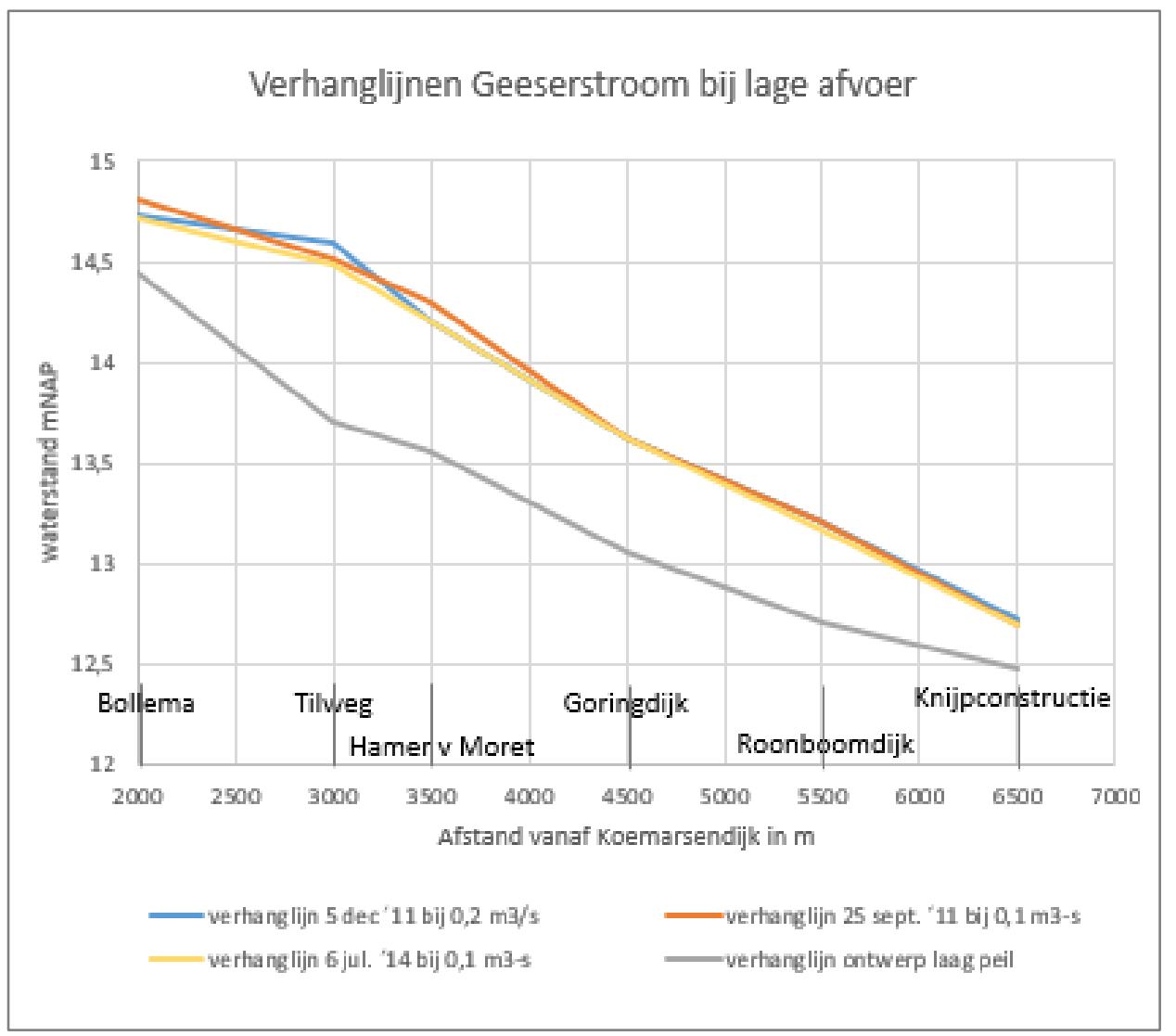

$\mathrm{B}$

Figuur 3.1 Verhanglijnen van het peil in de Geeserstroom bij hoge (A) en lage (B) afvoeren. 
De analyse van de waterstand achter gemaal Bollema in oktober 2015 laat zien dat het peil fors hoger is dan in het inrichtingsplan is voorzien (figuur 3.2). In het inrichtingsplan is aangenomen dat de oppervlaktewaterstand in het Geeserstroomgebied in droge periodes rond NAP $+13,85 \mathrm{~m}$ en in natte periode rond NAP $+14,45 \mathrm{~m}$ zou worden. Uit een vergelijking tussen de grafiek en het inrichtingsplan wordt duidelijk dat de oppervlaktewaterstanden in de praktijk fors hoger zijn.

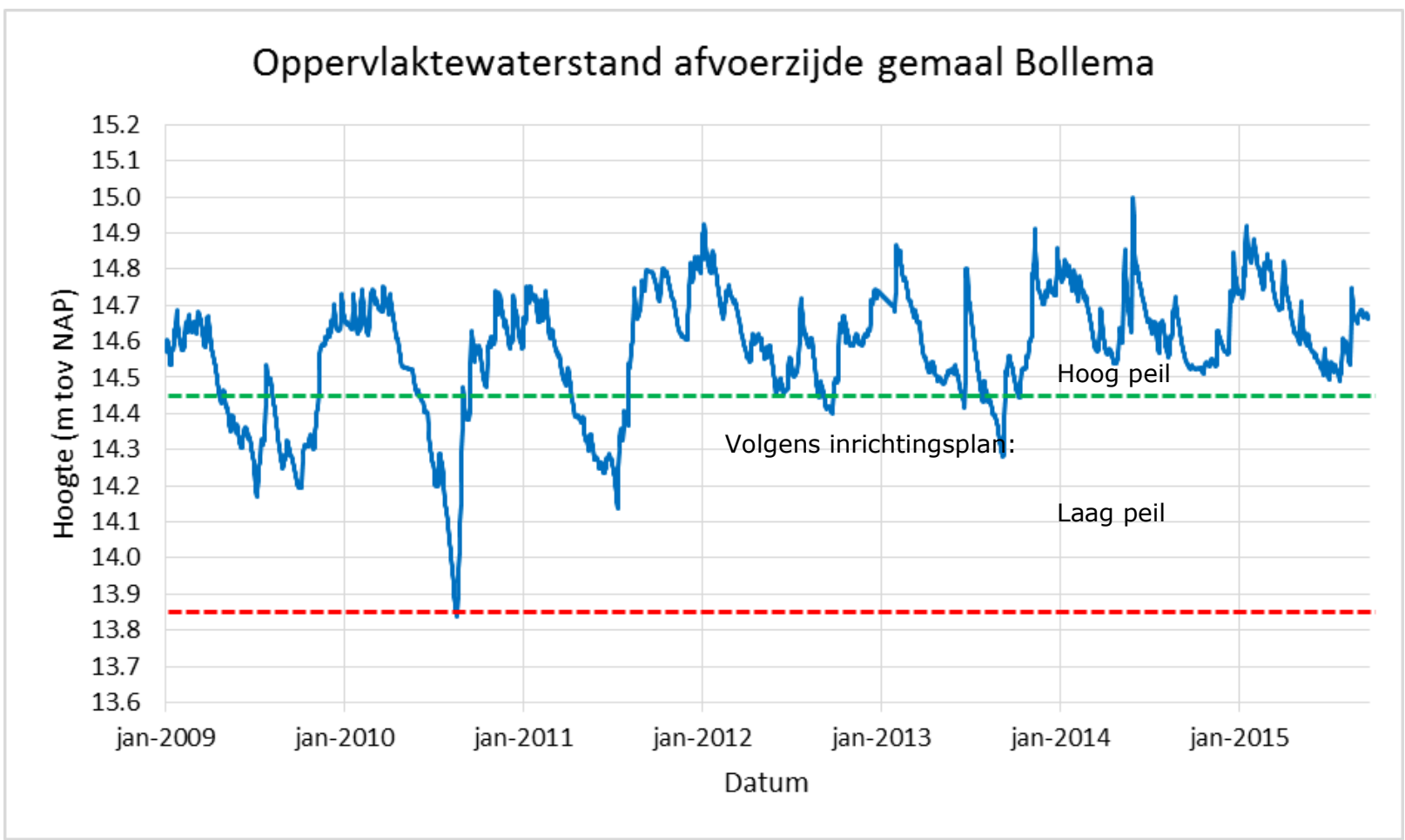

Figuur 3.2 Het waterpeil benedenstrooms van gemaal Bollema met de vastgestelde norm voor hoog (groene stippellijn) en laag peil (rode stippellijn).

In droge periodes is de oppervlaktewaterstand een korte periode rond de verwachte waarde van NAP $+13,85$ m geweest, maar is een trend waarneembaar naar NAP $+14,30 \mathrm{~m}$ tot $+14,50 \mathrm{~m}$. Daarmee is het peil circa $0.60 \mathrm{~m}$ hoger dan de verwachting.

De droogleggingskaarten bij hoge en lage standen (figuur 3.3) geven een goed beeld van de variatie in de gemeten oppervlakte- en grondwaterstanden. Bij hoge standen inundeert het grootste gedeelte van het beekdal terwijl bij lage standen de Marssen en de Mepper Hooilanden droogvallen en in het benedenstroomse gedeelte alleen in de uitgegraven bedding en in enkele lage delen nog water staat. 


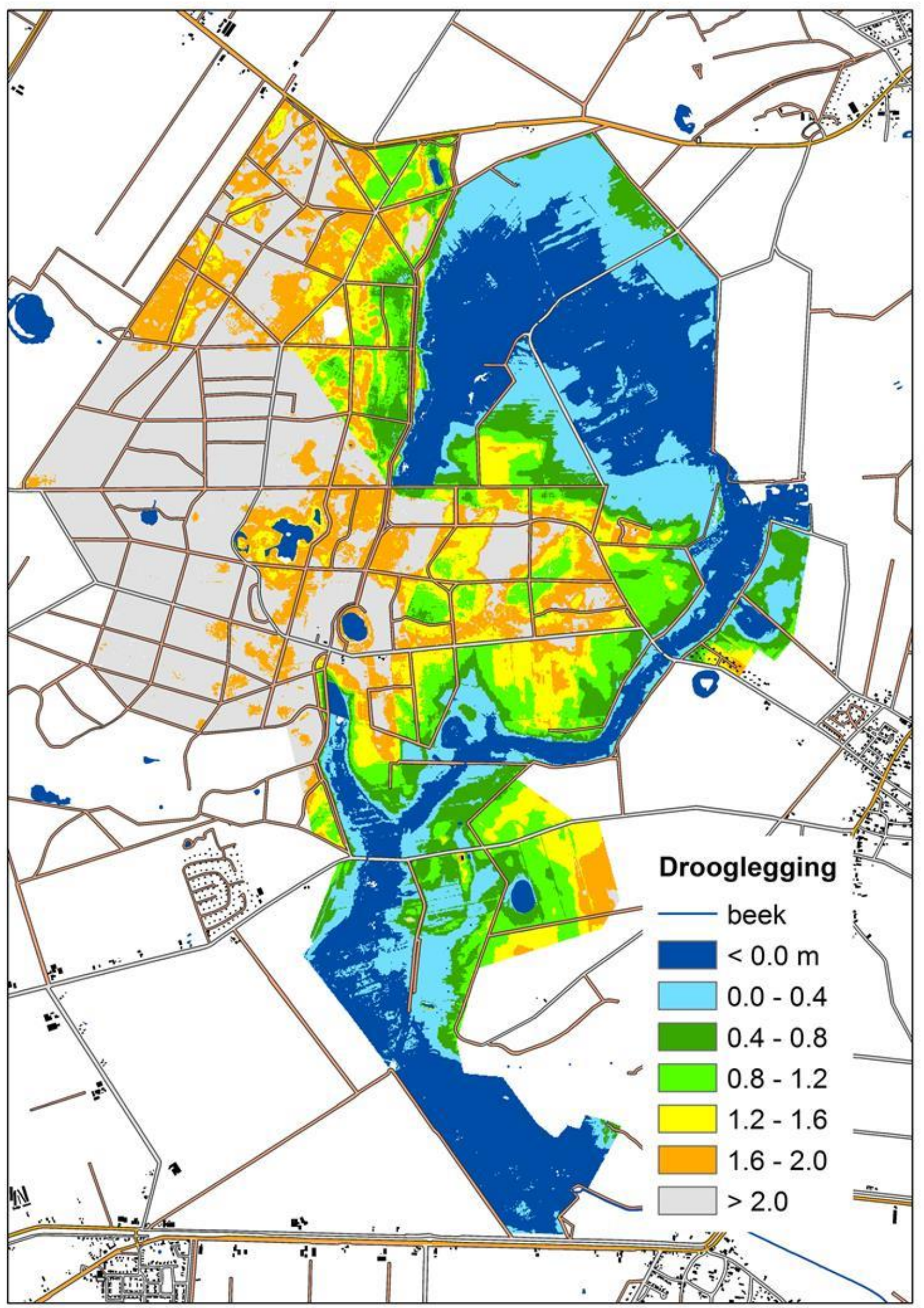

Figuur 3.3A Drooglegging bij hoge afvoeren. 


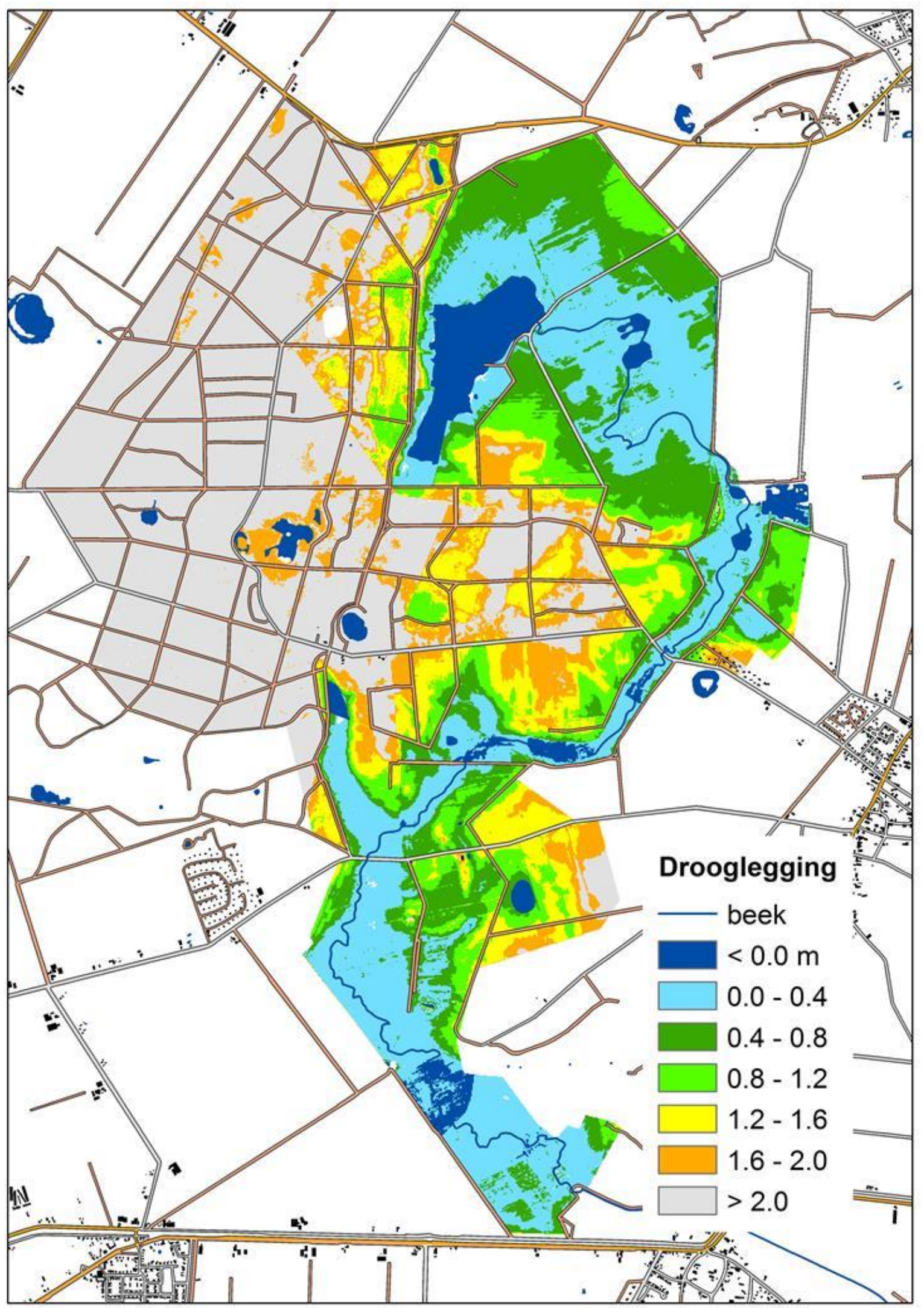

Figuur 3.3B Drooglegging bij lage afvoeren. 


\subsection{Aanvullende analyse}

De oppervlaktewaterstanden en grondwaterstanden zijn medio 2015 verzameld en geanalyseerd (zie ook paragraaf 3.2). Aanvullende metingen over de afgelopen maanden leverden geen nieuwe inzichten op. Wel blijkt uit een aanvullende analyse van het diepe grondwater dat door de maatregelen niet alleen de freatische grondwaterstanden en de oppervlaktewaterstanden zijn gestegen, maar ook dat de stijghoogte van het diepe grondwater is toegenomen (figuur 3.4). Het betreft hier de stijghoogte in het watervoerende pakket onder de keileem. Duidelijk is te zien dat na de maatregelen die in 2005 genomen zijn de standen hoger zijn. Ervoor en erna zijn geen dalende of stijgende tendensen zichtbaar. Keileem zelf is erg slecht doorlatend, maar er zijn ook plekken in en rond het stroomdal waar geen keileem voorkomt. Daar zorgt, door de hogere freatische standen, een grotere neerwaartse grondwaterstroming voor de extra aanvulling. Op de plekken waar geen keileem voorkomt en de stijghoogte hoger is dan de freatische grondwaterstand - zoals in het benedenstroomse deel van de Geeserstroom - zal de kwel zijn toegenomen. De complexe opbouw van de ondergrond blijkt ook uit de systeemcondities (Bijlage 3). De keileemkaarten (niet opgenomen) geven een schematische weergave van de dikte, verspreiding en diepte, maar de exacte weerstand tegen verticale stroming is onbekend. Ook het beekleem vormt een barrière voor de grondwaterstroming. Eén en ander maakt dat het niet mogelijk is om stromingsbeelden van het grondwater gedetailleerd in kaart te brengen.

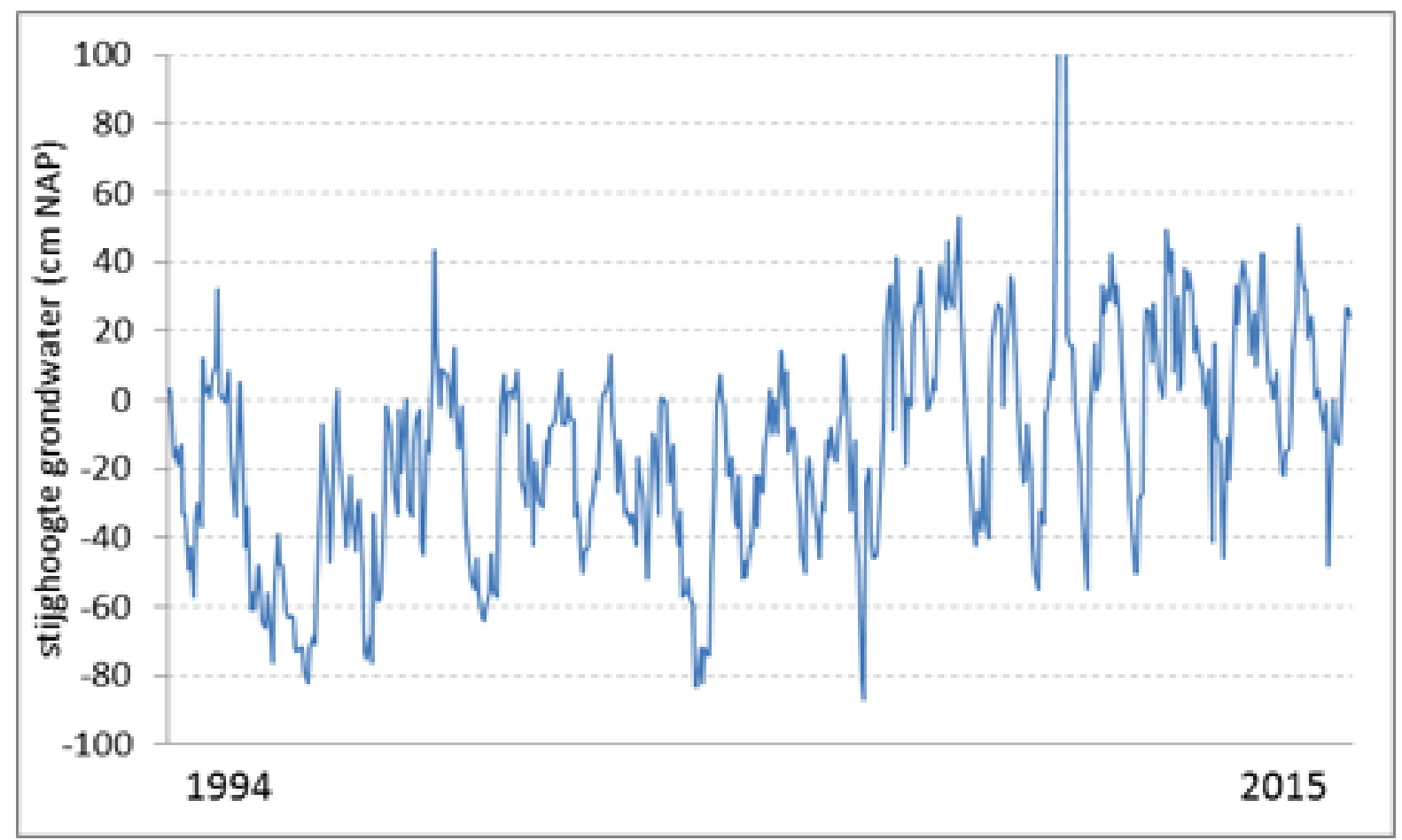

Figuur 3.4 Stijghoogte van het diepe grondwater bij Roonboom in de periode 1994-2015.

Uit de kaarten van de drooglegging bij een lage en een hoge afvoer en de grondwaterstandswaarnemingen van de 8 meetbuizen in het stroomgebied van de Geeserstroom zijn kaarten afgeleid met lage en hoge grondwaterstanden (figuur 3.5 en 3.6) alsmede de fluctuatie (figuur 3.7) en de duur dat het beekdal geïnundeerd is (figuur 3.8). 
Voor de kaarten met de grondwaterstanden zijn verbanden gebruikt tussen de drooglegging bij de acht meetplekken in januari 2011 (lage afvoer) en de grondwaterstanden op dat moment en idem van december 2012 (hoge afvoer). Tijdens de hoge afvoer in januari 2012 waren de grondwaterstanden ook hoog, maar tijdens de lage afvoer in december 2011 waren de grondwaterstanden min of meer gemiddeld. In plaats van die standen zijn 'gemiddeld' laagste standen geschat uit de tijd-stijghoogtelijnen. De correlatiecoëfficiënten tussen drooglegging en grondwaterstand was voor de hoge standen $r^{2}=0,87$ en de lage standen $r^{2}=0,96$. De grondwaterstandskaarten geven globale beelden van de standen die rond de GLG en GHG op kunnen treden. Mogelijk zijn de standen in kwelzones (Roonboom) wat te laag en de lage standen op de plekken met keileem, als de grondwaterstanden tot daaronder wegzakt, wat te hoog uitgevallen. In meer uitzonderlijke gevallen komen er lagere grondwaterstanden voor dan de berekende lage grondwaterstanden. Het gaat dan in figuur 3.5 om een klasse verschil.

Voor de fluctuatie (figuur 3.7) zijn de standen van de figuren 3.5 en 3.6 elkaar afgetrokken. Op de plekken die 's winters blank staan maar 's zomers niet is de diepte van de grondwaterstand ten opzichte van maaiveld genomen. Op de overgang van de plekken die permanent geïnundeerd zijn, is de abrupte overgang enigszins uitgevlakt.

Voor de afbeelding met de inundatieduur (figuur 3.8) zijn de waterstanden van de buis B1452, die langs de beek staat, gebruikt. Daarmee is een verband afgeleid tussen drooglegging en inundatieduur. Het rechtlijnige verband is wat aangepast om tegemoet te komen aan de lagere delen (Roonboom) waar een geringere inundatiediepte relatief langer aanhoudt. De inundatieduur geeft een globale indicatie. Afgezien daarvan kunnen er grote afwijkingen optreden door jaarlijkse verschillen in neerslaghoeveelheid en de verdeling ervan over het jaar en de aanwezigheid van keileem die tot langdurig hoge grondwaterstanden kan leiden. 


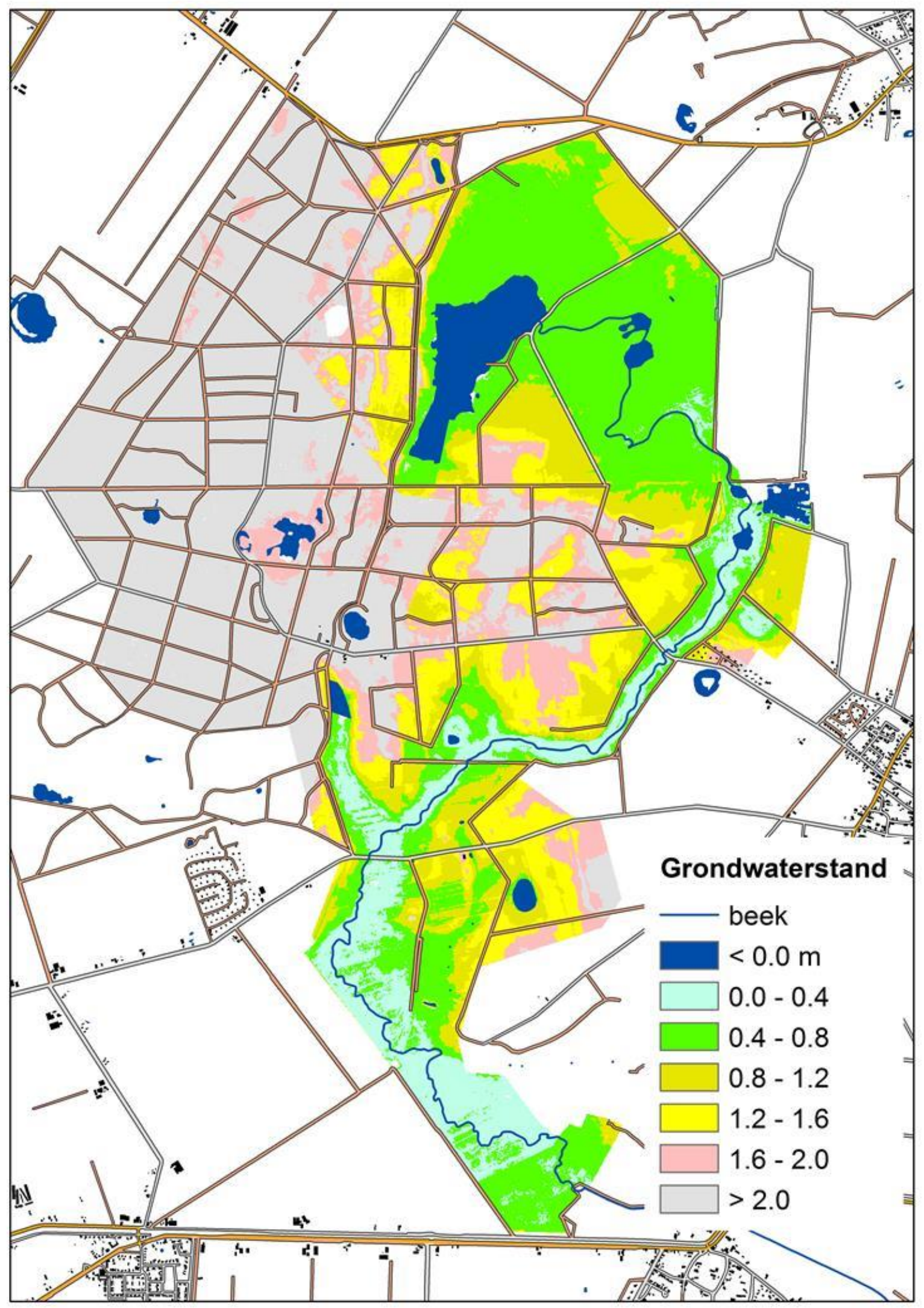

Figuur 3.5 Lage grondwaterstanden in het stroomgebied van de Geeserstroom 


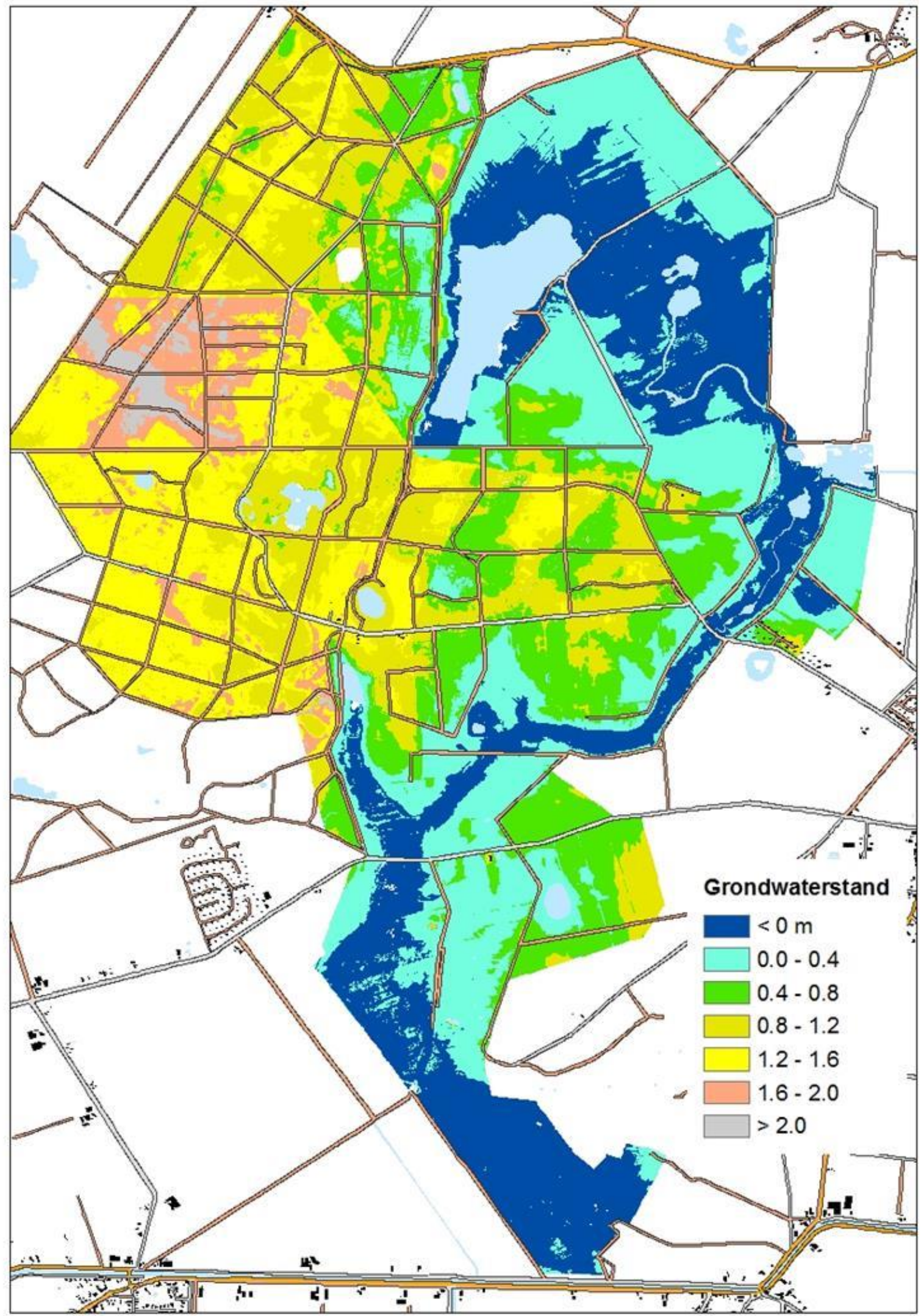

Figuur 3.6 Hoge grondwaterstanden in het stroomgebied van de Geeserstroom. 


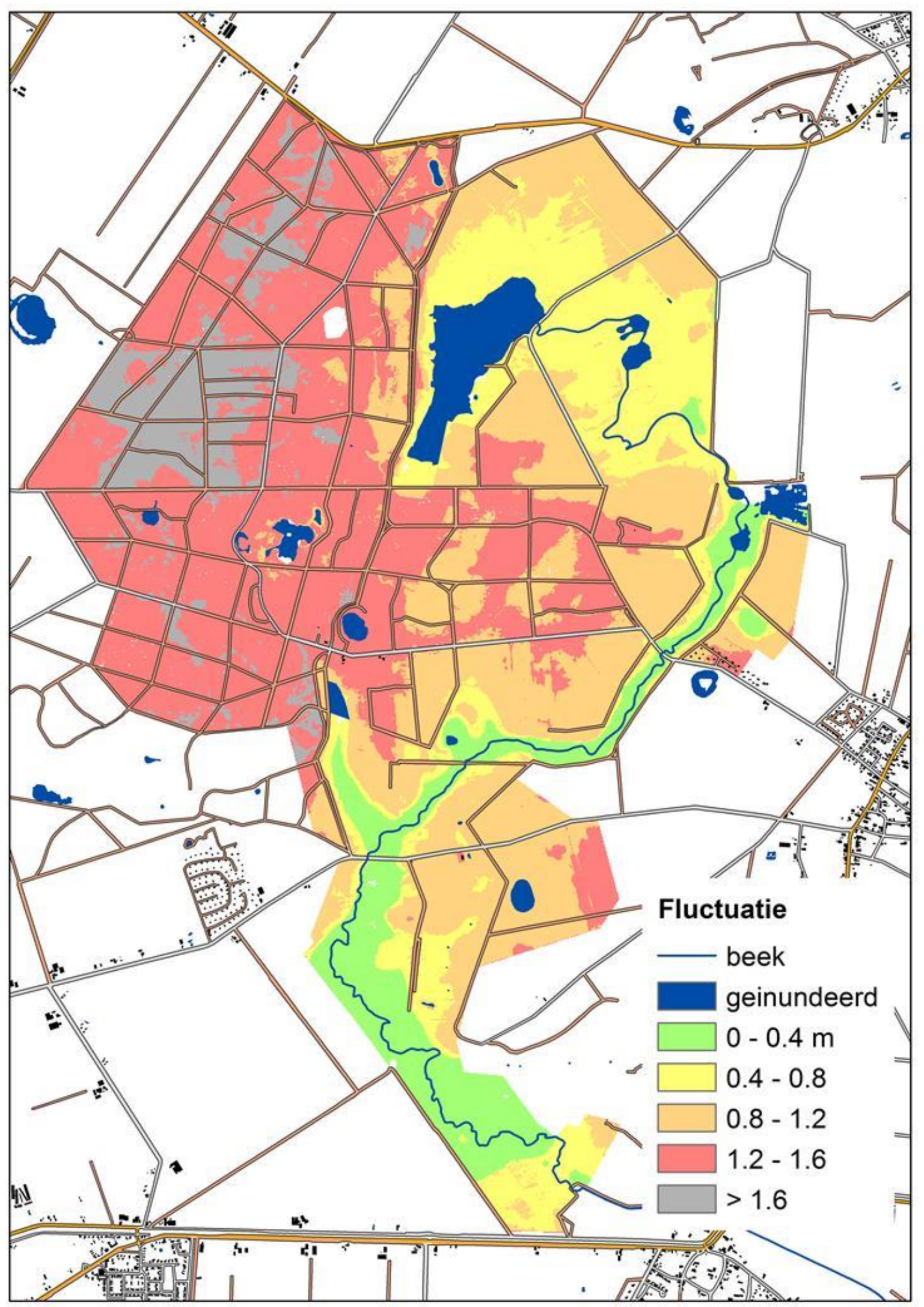

Figuur 3.7 Fluctuatie van grondwaterstanden in het stroomgebied van de Geeserstroom. 


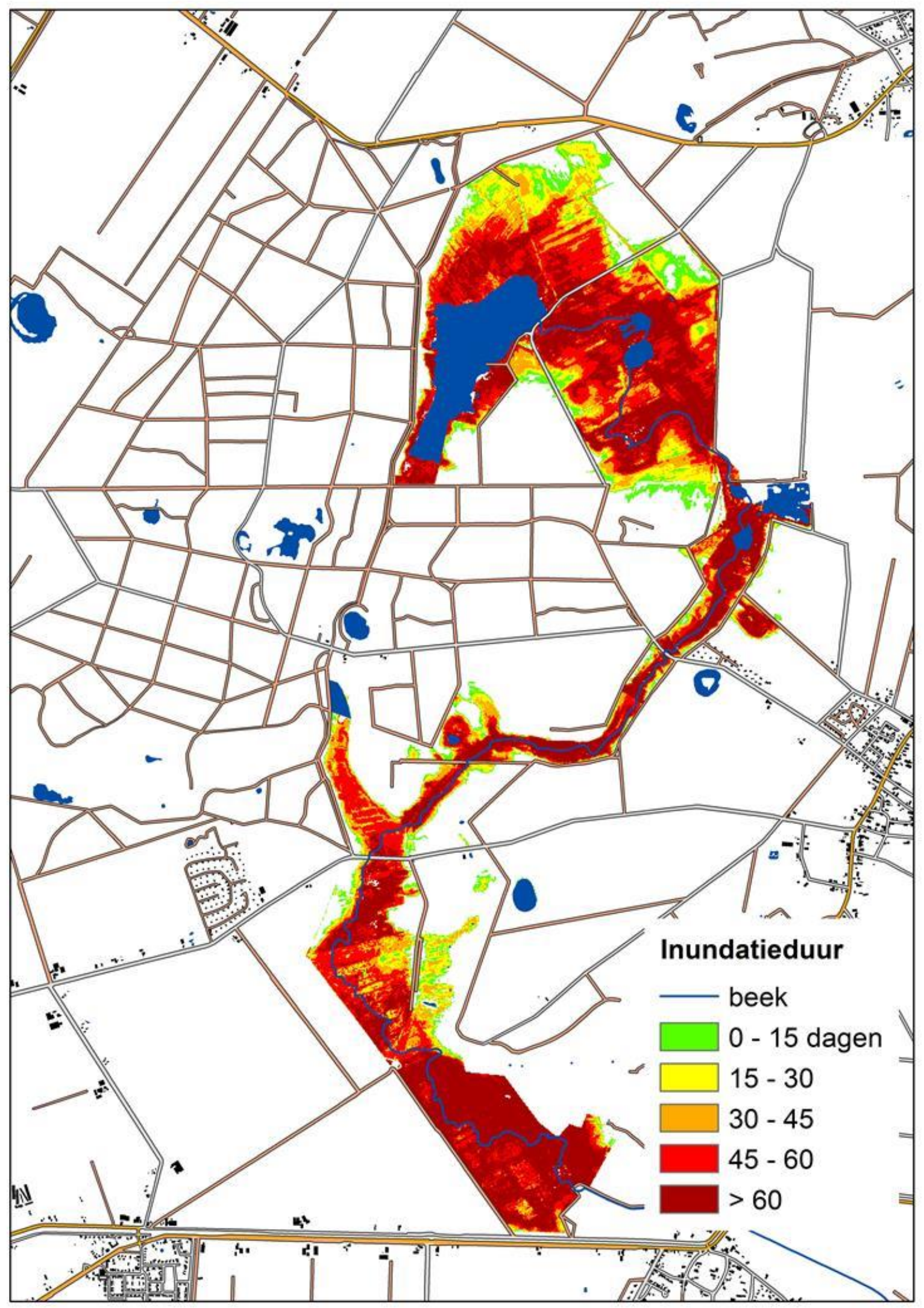

Figuur 3.8 Duur van inundatie in het beekdal van de Geeserstroom. 
De grondwaterstanden die wat hoger zijn dan in de planvorming is aangenomen vormen geen echt knelpunt. De te hoge (grond-)waterstanden in de afgegraven Mepper Hooilanden kunnen als positief worden beschouwd vanwege de ornithologische waarden die zijn ontstaan, maar sluiten niet aan bij de oorspronkelijke wens tot moerasontwikkeling. Er is slechts lokaal enige veengroei op gang gekomen. De erg hoge waterstanden achter gemaal Bollema zijn wel een reëel probleem. Om de waterstanden daar te verlagen zal het oppervlaktewater sneller moeten worden afgevoerd.

De formule die gebruikt wordt in de waterbeheersing om op grond van het debiet (Q) waterlopen te dimensioneren, de formule van Manning ${ }^{1}$, geeft goed inzicht in de parameters die daarvoor bepalend zijn:

$\mathrm{Q}=$ debiet $\mathrm{m}^{3} \cdot \mathrm{s}^{-1 / 2}$

$$
\mathrm{Q}=\mathrm{A} \cdot \mathrm{R}^{2 / 3} \mathrm{kmS}^{1 / 2}
$$

$A=$ natte oppervlakte

$\mathrm{R}=$ hydraulische straal (=A/natte omtrek)

$\mathrm{km}=$ wandruwheidsfactor

$\mathrm{S}=$ waterspiegelverhang (=bodemverhang)

De natte oppervlakte volgens het oorspronkelijke ontwerp is: $4 \mathrm{~m}^{*} 0,4 \mathrm{~m}=1,6 \mathrm{~m}^{2}$. Uit de formule volgt bijvoorbeeld dat een breed, ondiep profiel een lager debiet heeft dan een dieper profiel met een smallere bodem met een even groot nat oppervlak. In vergelijking met een $0,8 \mathrm{~m}$ diepe sloot is debiet $33 \%$ kleiner.

Het verhang tussen Bollema en de knijpconstructie (figuur 2.2) is ca. 1,75 m over $4500 \mathrm{~m}$. Stel de afstand bedraagt geen $4500 \mathrm{~m}$ maar 3000 dan neemt het debiet als gevolg van deze factor met $22,5 \%$ toe. De aanwezigheid van duikers, bruggen zorgen voor extra weerstand, waardoor het beschikbare verhang mogelijk minder is dan de eerder genoemde 1,75 m.

De wandruwheidsfactor is sterk afhankelijk van de begroeiingstoestand en neemt af van ongeveer 30-45 bij een zeer schone sloot naar $<10$ bij een zeer sterk begroeide sloot (Cultuurtechnisch Vademecum). In figuur 3.9 is de relatie van $\mathrm{km}$ met de waterdiepte weergegeven. Deze neemt snel af bij waterdiepten kleiner dan $40 \mathrm{~cm}$. Het Cultuurtechnisch Vademecum geeft als advies voor de afvoer: "Wil men vanwege natuur- of landschapswaarden of uit kostenoverwegingen minder frequent onderhoud uitvoeren, dan moet men voor het ontwerpen van de waterlopen de km-waarde hierop aanpassen." Uit het voorgaande blijkt dat de afvoer zeer gevoelig is voor de $\mathrm{km}$ factor. De $\mathrm{km}$-factie is zeer gevoelig voor de waterdiepte en de onderhoudstoestand van de sloot. Als de Geeserstroom buiten haar oevers treedt zal het aangrenzende beekdal overstromen. Daar komt een laagje water op het maaiveld te staan, maar door de hoge ruwheid van het maaiveld draagt dat nauwelijks bij aan de afvoer.

Uit deze analyse blijkt dat de oplossing die past bij een beekmoerasontwikkeling zonder aanvullend beheer, kan worden gezocht in:

1. Toename waterdiepte (>40 cm geeft gunstige $\mathrm{km}$ )

2. Vergroting van het doorstoomprofiel (grotere $A$ )

\footnotetext{
${ }^{1}$ Griffioen en Pitlo (1991) hebben de formule uitgebreid met een tweede deel voor begroeide waterlopen: $Q=A_{1} \cdot R_{1}{ }^{2 / 3} k_{m} S^{1 / 2}+W A_{2} S$ Hierin is : W geleidbaarheidswaarde in het begroeide deel $(\mathrm{m} / \mathrm{s})$.

$W$ is afhankelijk van het type begroeiing en varieert van 30 voor grasachtige en ondergedoken soorten, naar 100 voor riet tot 700 voor watergentiaan (Cult. Vad.)
} 
3. Vergroting van het verhang door weglengte verkorting

4. Type begroeiing

5. Verwijdering/vergroten/onderhouden van weerstanden zoals duikers, bruggen

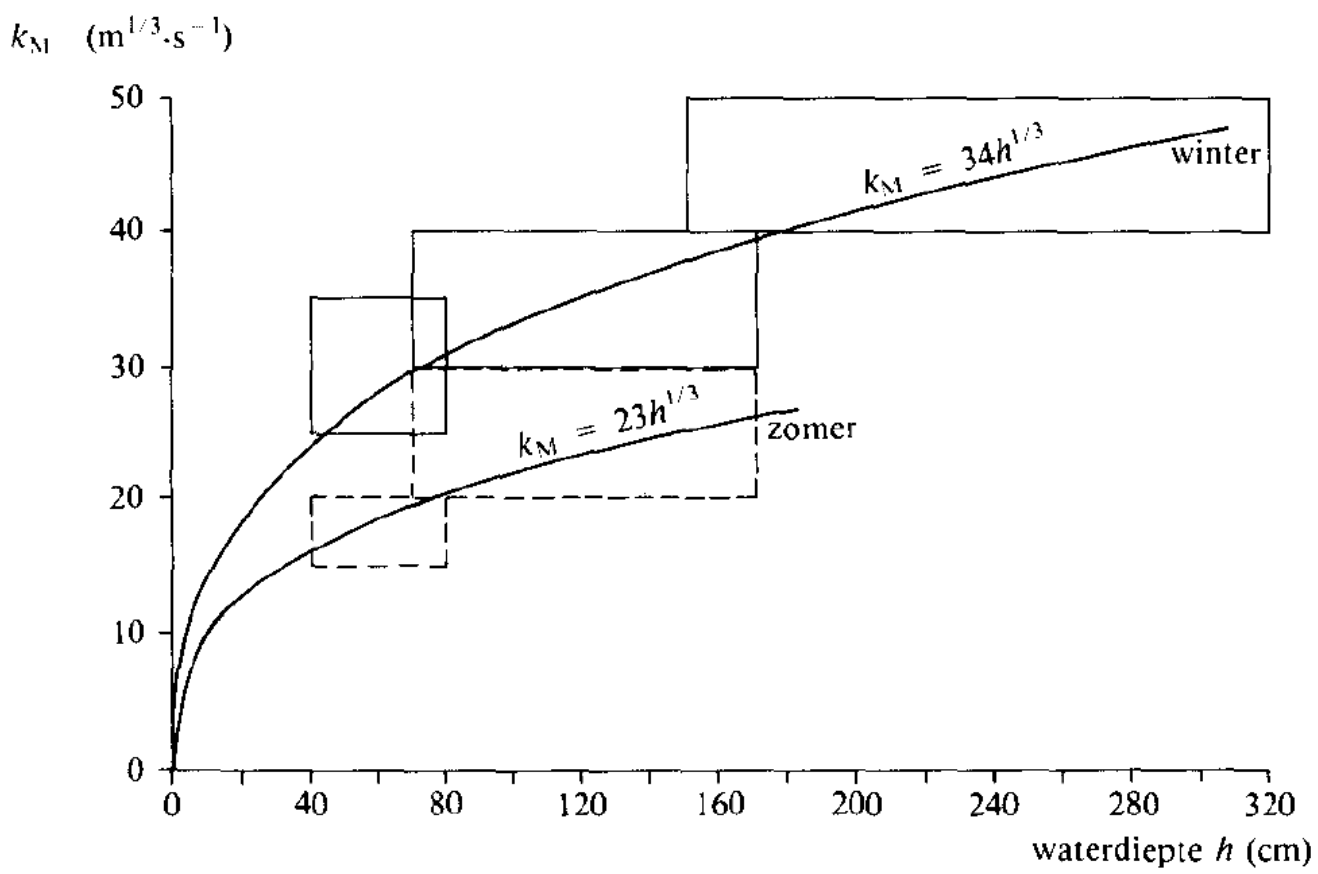

Figuur 3.9 Verband tussen wandruwheid $\mathrm{km}$ en waterdiepte $\mathrm{h}$.

\subsection{Modelberekeningen}

Er zijn 4 plekken in het stroomgebied geselecteerd waar met het hydrologische model SWAP berekeningen voor zijn uitgevoerd. SWAP is een ééndimensionaal waterbalansmodel dat de dynamiek beschrijft van het verticale vochttransport in de onverzadigde zone (Kroes en van Dam, 2003). SWAP kan als een bodemkolom worden beschouwd die is opgebouwd uit maximaal 40 compartimenten. leder compartiment heeft een eigen dikte en bodemfysische eigenschappen. Via het onderste compartiment vindt wegzijging en/of kwel plaats en via het bovenste compartiment neerslag en evaporatie. De gewasverdamping vindt plaats vanuit de compartimenten waarin zich wortels bevinden. De waterbewegingen van en naar de waterlopen lopen via de zijkanten van de compartimenten.

De locaties van de vier pekken staan in figuur 3.11. Behalve bij plek 1, in het bergingsgebied Roonboom, komt keileem of beekleem in de ondergrond voor. De plekken 2 en 3 liggen in het beekdal, plek 2 even bovenstrooms van de Hamer van Moret en plek 3 iets benedenstrooms van de klepduiker die voor de plas bij gemaal Bollema ligt. Plek 4 ligt in de Mepper Hooilanden.

De periode die is doorgerekend beslaat 21 jaar (1995 t/m 2015). Van die periode zijn stijghoogtes van het diepere grondwater bekend. Voor de neerslag zijn de gegevens van neerslagstation Zweeloo gebruikt en voor de verdamping die van Eelde. Als vegetatie is voor alle vier de plekken een moerasachtige vegetatie gekozen die ook onder erg natte omstandigheden blijft verdampen. Het drainagepeil is geschat aan de hand van de beekpeilen, de slootafstanden op basis van de slootdichthedenkaart (Massop pers. med.) en 
voor de drainageweerstanden is gekeken naar de aan-/afwezigheid van waterlopen, greppels en laagtes. In bijlage 1 staat de informatie die gebruikt is voor de parameterisatie van de bodem en de drainage-eigenschappen.

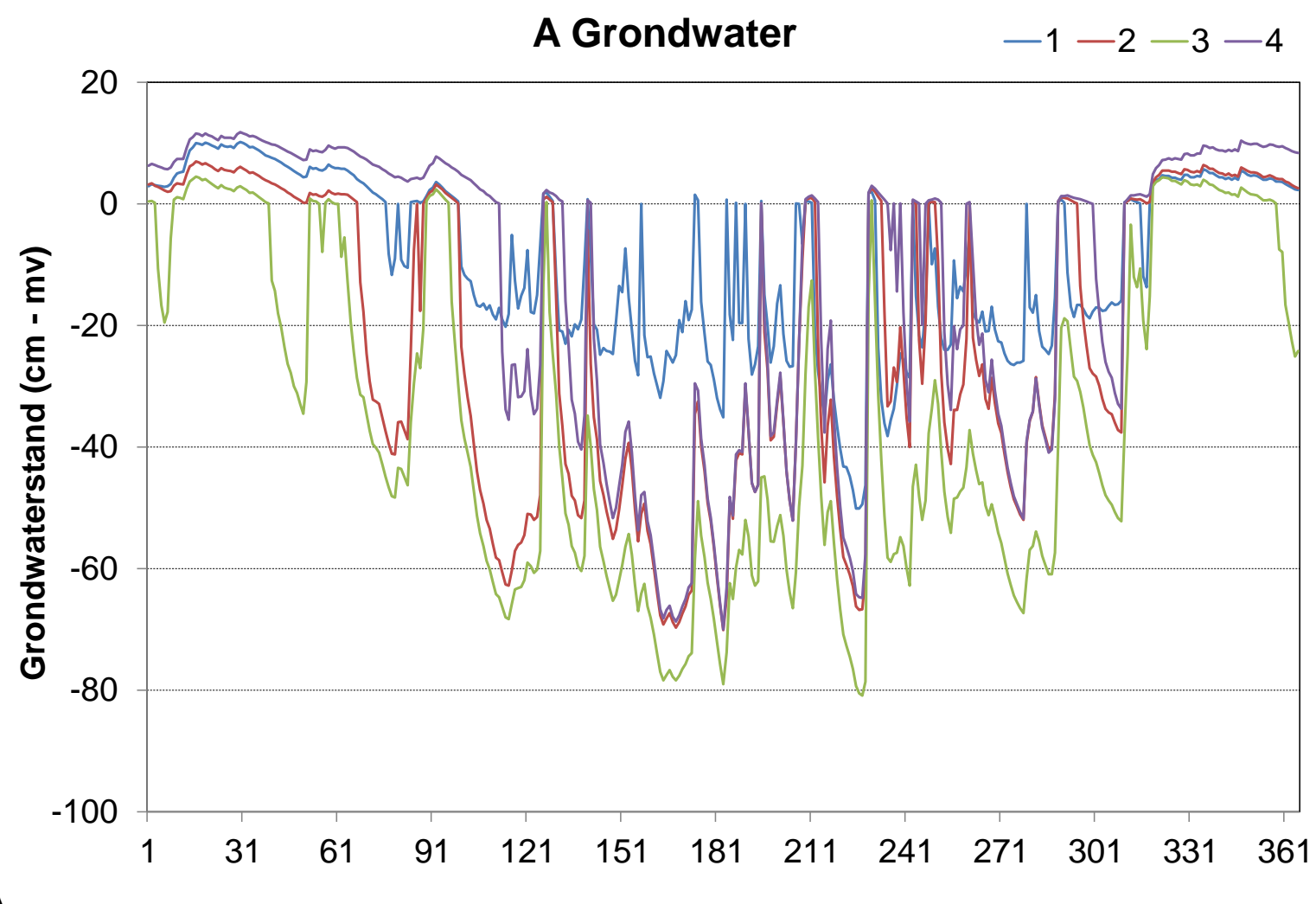

A

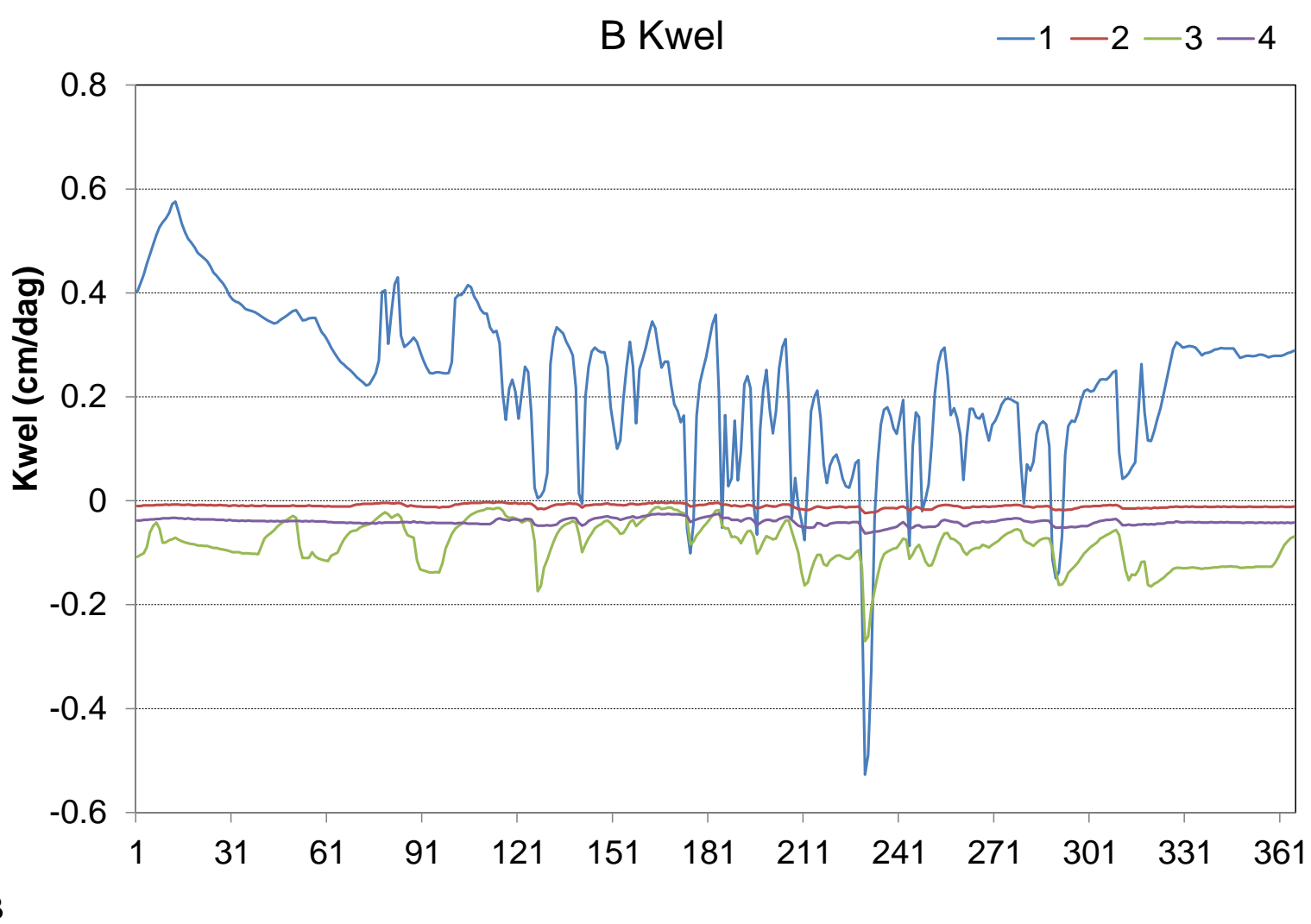




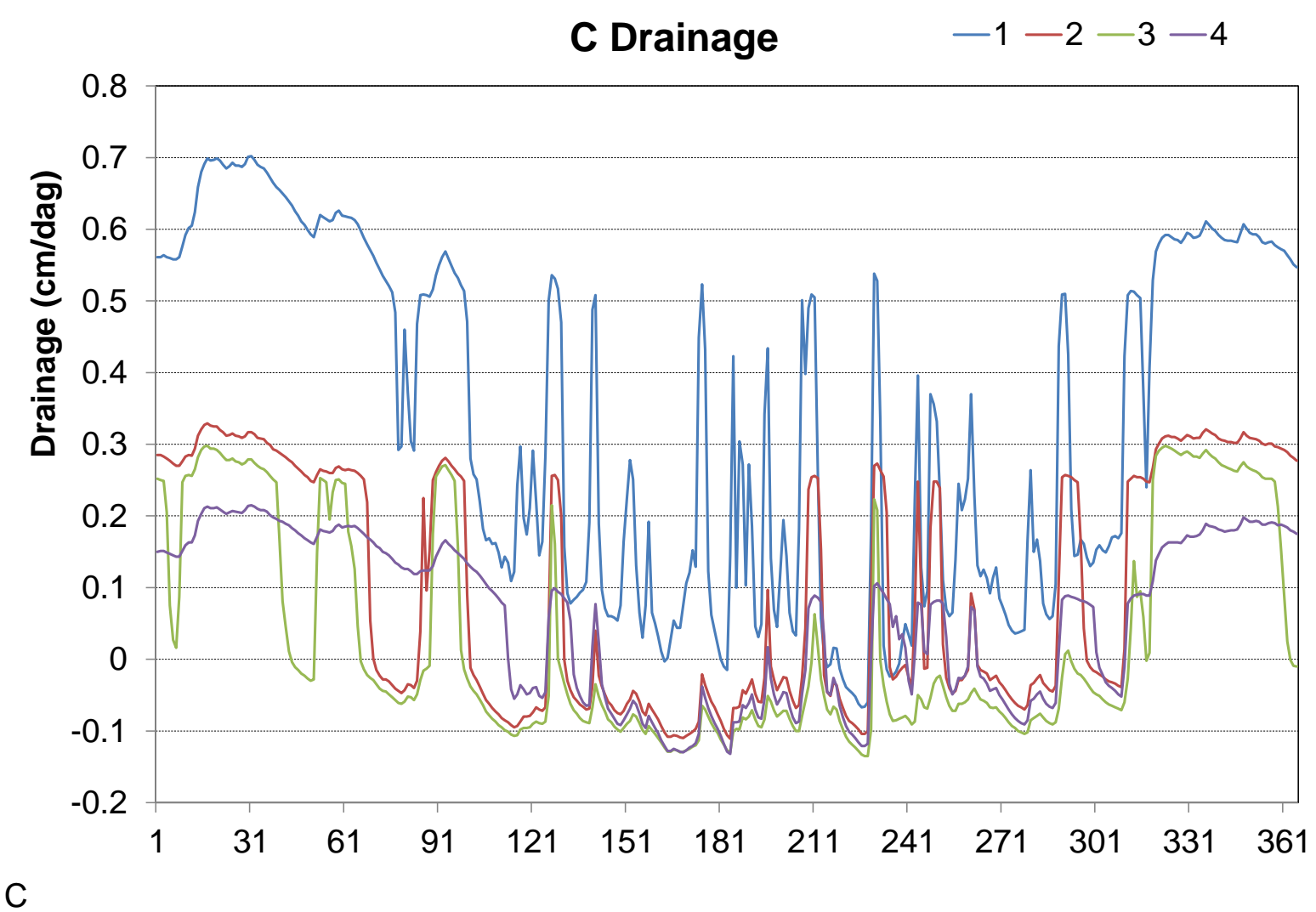

Figuur 3.10 De grondwaterstand (A), kwel (B) en drainage (C) op de 4 meetplekken voor 2015 (zie figuur 3.11).

In figuur 3.10 staan de berekende grondwaterstanden (A), de kwel (B) en de drainage (C) van de 4 plekken voor het jaar 2015. De grondwaterstanden zijn representatief voor de flanken van het beekdal. De drainage $(\mathrm{C})$ vindt plaats via laagtes, greppels en de beek. Bij plek 1, waar geen keileem in de ondergrond voorkomt, zijn de grondwaterstanden hoog en er komt een forse kwelflux voor. Bij plek 2 treedt nauwelijks kwel en wegzijging op door de aanwezigheid van keileem. Bij 3 is beekleem aanwezig en treedt een geringe wegzijging op. Bij 4, in de Mepper Hooilanden, treedt ook wegzijging op, maar die wordt beperkt door de aanwezigheid van keileem. De resultaten, die slechts een globaal beeld van de huidige situatie geven, zijn primair bedoeld als referentie voor de berekeningen met de voorgestelde maatregelen (paragraaf 3.6). 


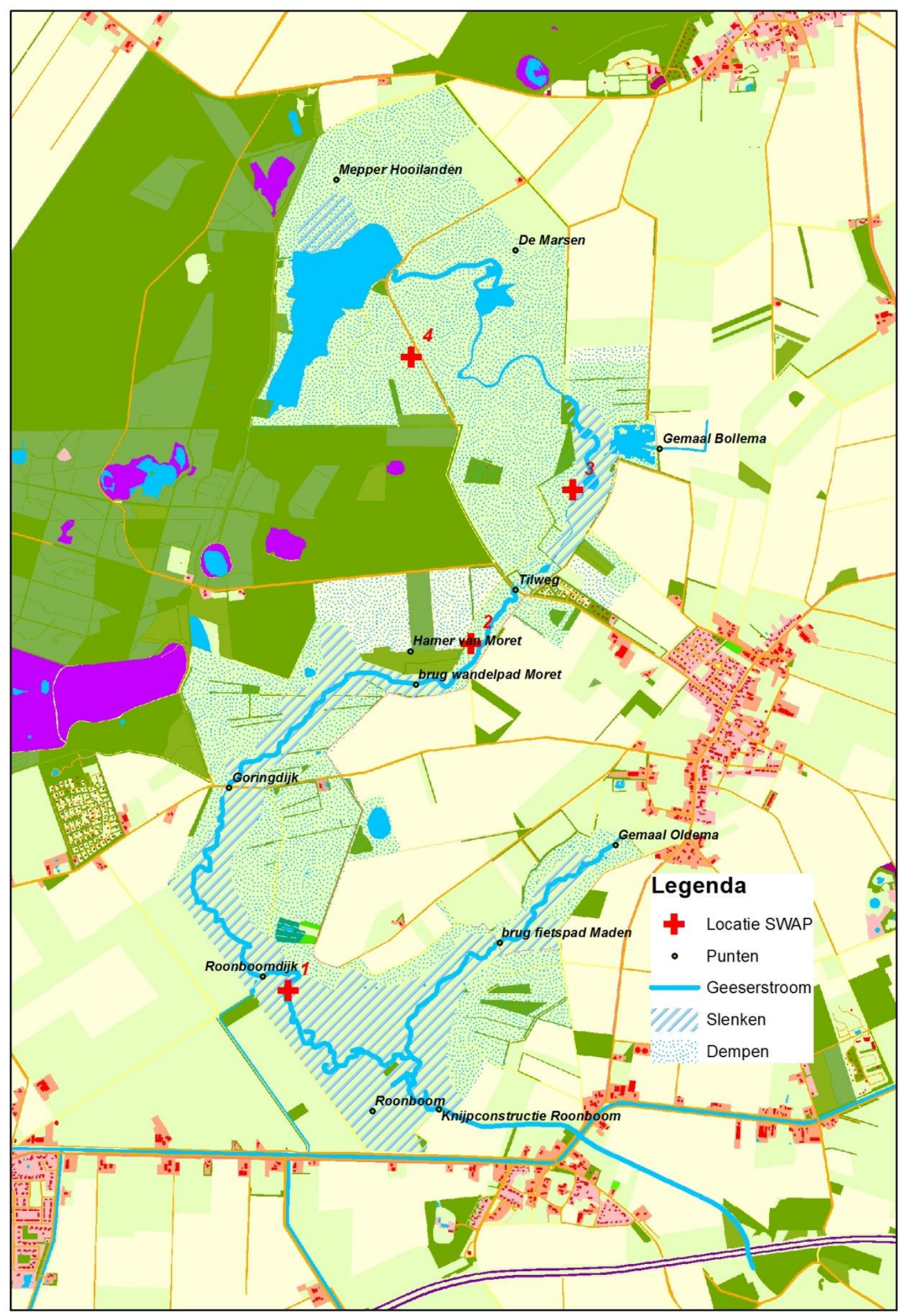

Figuur 3.11 Overzicht van het stroomgebied van de Geeserstroom met de 4 locaties waarvoor modelberekeningen (SWAP) zijn uitgevoerd. 


\subsection{Oplossingen voor de hydrologische knelpunten}

\section{Inventarisatie van mogelijke maatregelen}

Voor oplossingen van hydrologische knelpunten wordt gekeken naar de te natte situatie rond gemaal Bollema. Maatregelen die daar worden voorgesteld zijn, aangepast aan de lokale toestand, ook geschikt om uit te voeren rond gemaal Oldema dat Gees droog moet houden. Voor het oplossen van de te hoge oppervlaktewaterpeilen bij het gemaal Bollema en de Tilweg zijn eerst denkbare ingrepen geïnventariseerd. Het minst ingrijpend voor het beekdal is het accepteren van de huidige, natte situatie in het beekdal. In het beekdal zijn echter verschillende maatregelen mogelijk. Die staan in onderstaand overzicht.

In september 2016 is de hoofdstroom tussen Bollema en het eerstvolgende bruggetje voor de Goringdijk ingrijpend geschoond en is zand en vegetatie uit de zandvang voor de Tilbrug verwijderd. De duiker onder de Tilweg bleek niet verzand of dichtgeslibd. Door het schonen zakte het peil ongeveer $30-50 \mathrm{~cm}$.

Begroeiing elders in het beekdal kan nog een belemmering voor oppervlakkige afstroming bij hoge waterstanden opleveren. Met het oog op een natuurlijke ontwikkeling is dit een tijdelijke situatie. Door beschaduwing zal op termijn deze begroeiing ijler worden. In de ontwikkelingsperiode is begrazen of maaien alleen lokaal mogelijk omdat anders de boomontwikkeling wordt tegengegaan. Het periodiek onderhouden van kunstwerken als duikers en bruggen of beter nog het aanpassen van kunstwerken door het verhogen van een brug of vlonder of de aanleg van een voorde zal bijdragen aan het waarborgen van de doorstroming.

De randvoorwaarde dat het beekdal zich natuurlijk moet kunnen ontwikkelen maakt dat er geen structurele onderhoudsmaatregel worden voorgesteld. Het aanpassen van het beekprofiel biedt goede mogelijkheden om voor de langere termijn de wateroverlast achter gemaal Bollema tegen te gaan. Voor de aanpassing komen bodemhoogte, verhang en het doorstroomprofiel in aanmerking. De begroeiing speelt hierbij een belangrijke rol.

\section{Bodemhoogte}

Om het peil achter de klepduiker bij gemaal Bollema zover te verlagen dat de waterstanden uit het ontwerpplan worden benaderd zou de bodemhoogte van de Geeserstroom kunnen worden aangepast en de afvoercapaciteit kunnen worden vergroot. Volgens het ontwerpplan is $13,85 \mathrm{~m}+\mathrm{NAP}$ een lage waterstand bij de klepduiker. Er wordt vanuit gegaan dat dat tevens de bodemhoogte is. Bij een stand van 13,85 m +NAP is er dan een plas/dras-situatie, zonder afvoer. Om de afvoercapaciteit te vergroten moeten het doorstroomprofiel en/of het verhang worden vergroot en/of de weerstand door begroeiing worden tegengegaan.

\section{Verhang}

In de huidige situatie bedraagt volgens figuur 3.1 het verhang in het traject Bollema-Tilweg $0,22 \mathrm{~m} / \mathrm{km}$ en verder stroomafwaarts, waar het verhang het grootst is, $0,62 \mathrm{~m} / \mathrm{km}$. De verlaging van de bodemhoogte achter de klepduiker bij Bollema zou betekenen dat het verhang in het traject Bollema-Tilweg afneemt en dat de afvoer daar nog trager wordt. In deze maatregel krijgt de bodem in het hele traject Bollema-Tilweg-Hamer van Moret eenzelfde verhang $(0,40 \mathrm{~m} / \mathrm{km})$. Tussen Bollema en Tilweg wordt het verhang daardoor groter waardoor de stroming daar met 35\% toeneemt. De doorstroming tussen Tilweg en Hamer van Moret verloopt dan wat trager, maar omdat daar het profiel wordt aangepast (zie hieronder) zal het niet tot hogere waterstanden leiden (zie paragraaf 3.6). 


\section{Doorstroomprofiel}

Het profiel dat bij de inrichting is uitgegraven is $4 \mathrm{~m}$ breed en $0,40 \mathrm{~m}$ diep. Uitgaande van een verhang van $0,22 \mathrm{~m} / \mathrm{km}$ en een (gebruikelijke) wandruwheidswaarde $\mathrm{Km}$ van 23 levert dat een debiet op van $0,26 \mathrm{~m} 3 / \mathrm{s}$.

De beek is momenteel dichtgegroeid waardoor de doorstroomcapaciteit sterk is afgenomen. Opschonen heeft ook alleen tijdelijk effect totdat de bomen de plantengroei gaan remmen. Daarom wordt voorgesteld om vanaf de klepduiker bij Bollema een bredere bedding uit te graven. Stroomafwaarts versmalt de bedding geleidelijk tot de oorspronkelijke $4 \mathrm{~m}$ op de plek bij de Hamer van Moret bereikt, waar de nieuwe bodemhoogte aansluit op de oude bodemhoogte. Er ontstaat dan een soort trechter waarin de bovenloop onder de gegeven randvoorwaarden voldoende afvoercapaciteit krijgt. Door de geleidelijke versmalling van de bedding in combinatie met de lagere bodemhoogte worden bij de versmalling de grondwaterstanden in de omgeving niet hoger (zie paragraaf 3.6).

\section{Weerstand door begroeiing}

Ook het breedste gedeelte van de beekbedding bij de klepduiker bij Bollema zal na verloop van tijd dichtgroeien. In figuur 3.12, die het verband laat zien tussen de breedte van de bedding en het debiet bij het nieuwe, grotere verhang $(0,40 \mathrm{~m} / \mathrm{km})$, is daar rekening mee gehouden. $\mathrm{Er}$ is uitgegaan van de toekomstige situatie waarbij de beek goeddeels is dichtgegroeid. Een breedte van $12 \mathrm{~m}$ (en diepte van 0,40 m) volstaat voor het eerder berekende debiet van $0,26 \mathrm{~m} / \mathrm{s}$. Als er grotere debieten optreden zal het peil boven $0,40 \mathrm{~m}$ uitkomen en zullen delen van het beekdal inunderen.

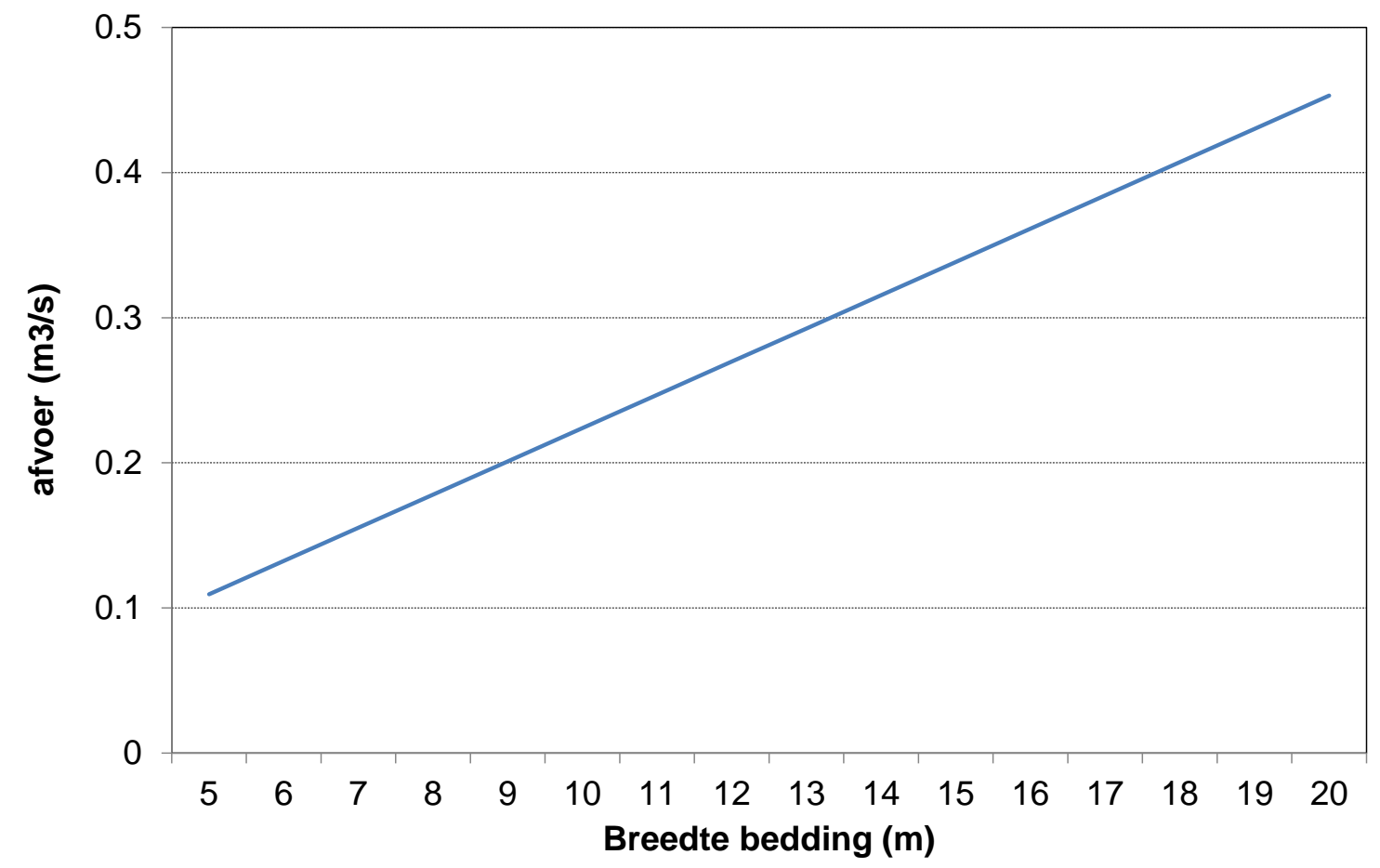

Figuur 3.12 Verband tussen de breedte van een dichtgegroeide beek met een Km van 15 en een $w W$ van 30 bij een diepte $40 \mathrm{~cm}$ en de afvoer. 
Voor de verbreding van de bedding is ervan uit gegaan dat die weer geleidelijk met een vegetatie dichtgroeit. Op termijn ontwikkelt echter een moerasbos met een dominantie van Elzen/Essen. Door schaduwwerking van het bos zal de ondergroei goeddeels verdwijnen. Daarom kan bij moerasbosontwikkeling met een minder ingrijpende aanpassing van het beekprofiel worden volstaan. Een combinatie van het weghalen van de knik in het verhang en een minder ingrijpende aanpassing van het doorstroomprofiel is daarom een goede optie. Het verbreden van het profiel blijft beperkt tot het herstel van de eerder uitgegraven bedding van 0,4 m diepte en $4 \mathrm{~m}$ breedte tussen Bollema en de Hamer van Moret en het ondiep plaggen van het aangrenzende gedeelte van het beekdal. Op deze wijze ontstaat een accoladeprofiel. Van belang hierbij is de hoeveelheid/dichtheid van de ondergroei die ontwikkeld. Bij weinig ondergroei, het gewenste uitgangspunt, zal in de formule van Manning de wandruwheid $\mathrm{Km}$ in de bedding toenemen tot bijvoorbeeld 18 en de geleidbaarheidswaarde W voor het afgeplagde deel tot 200 .

\subsection{Modelberekeningen}

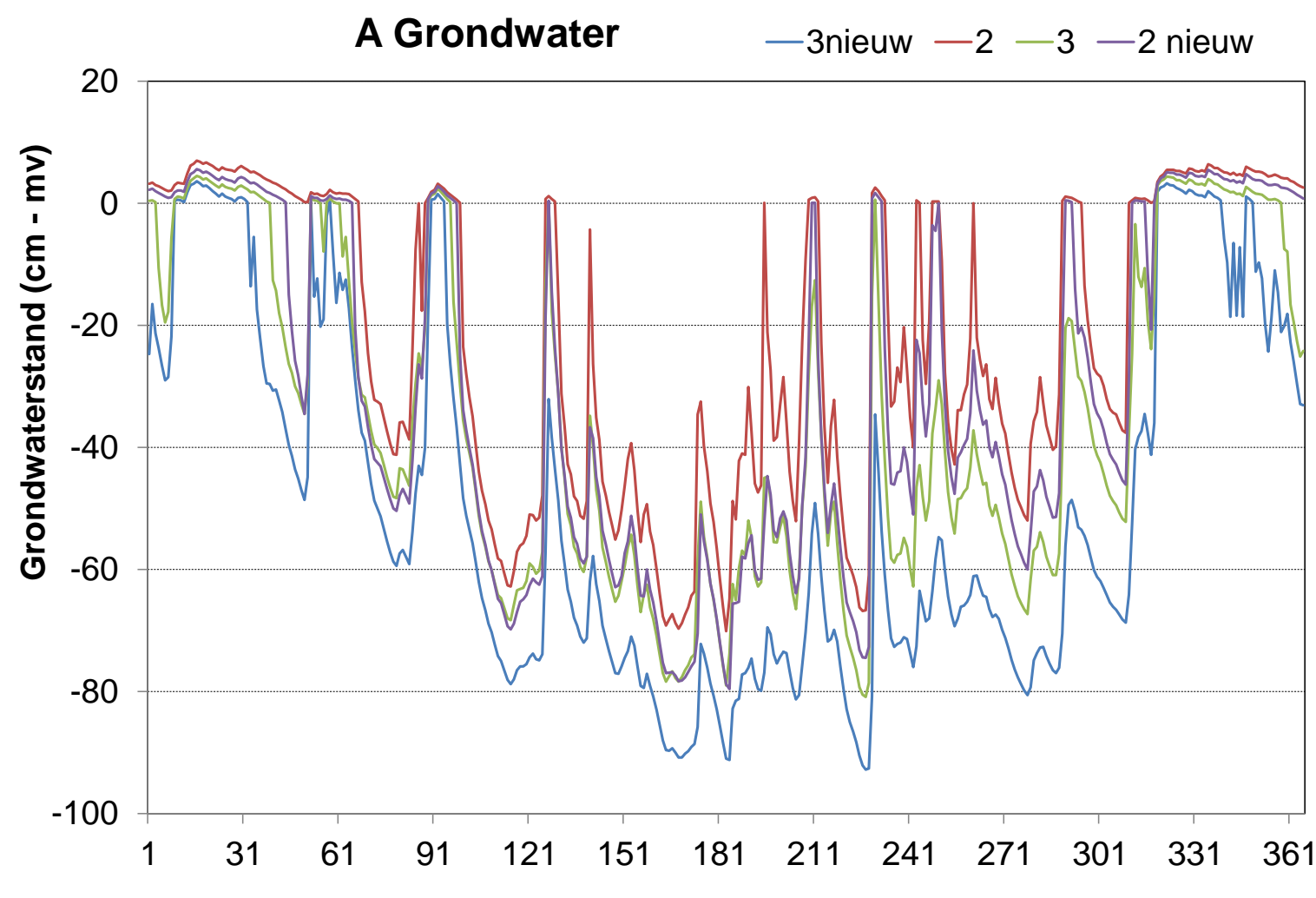

A 


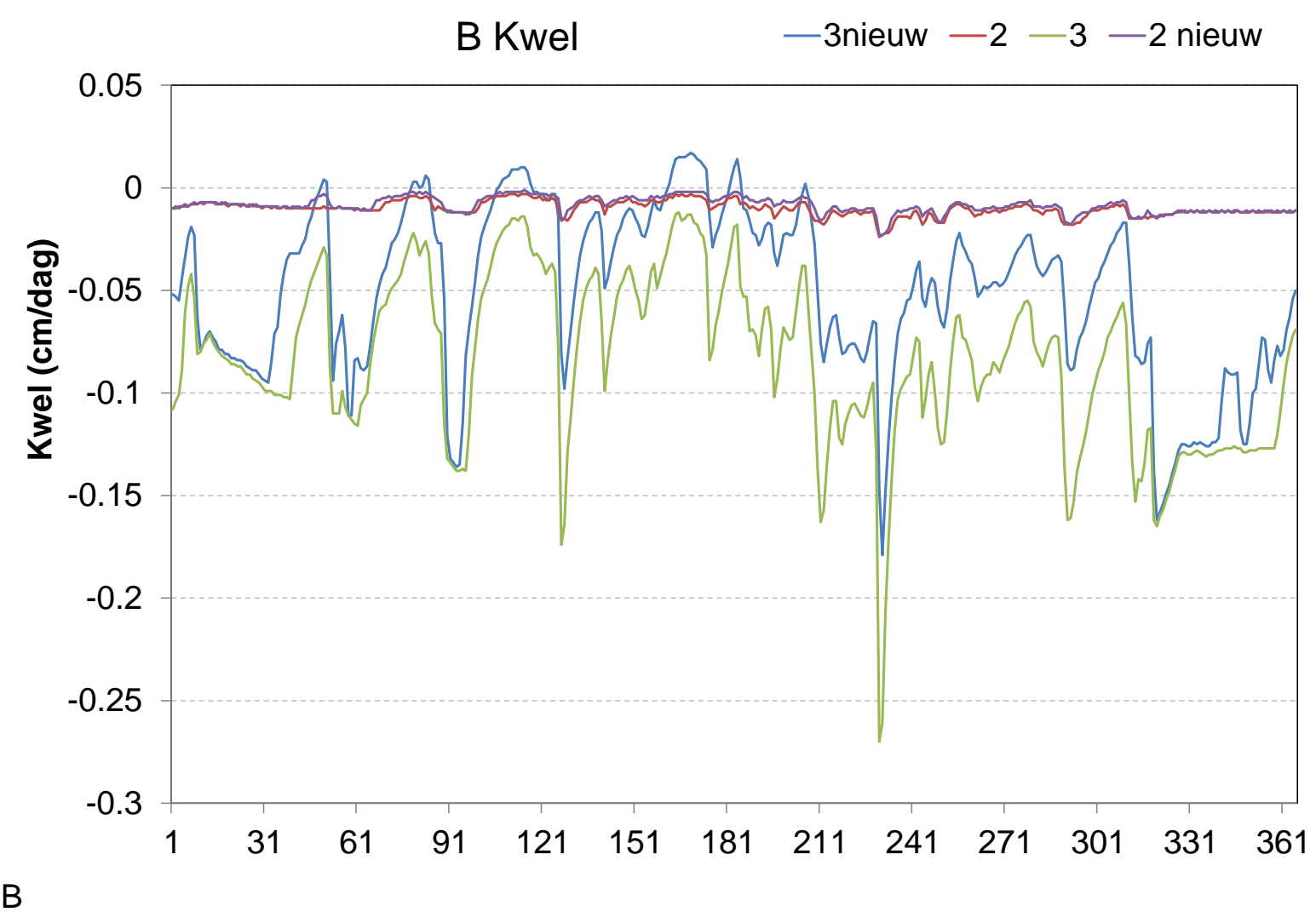

Figuur 3.13 Verandering van de grondwaterstand $(A)$ en kwel $(B)$ in 2015 op de plekken 2 en 3 (zie figuur 3.11) bij de voorgestelde ingreep in het beekprofiel.

Voor het verwijderen van de knik in het verhang zijn de modelberekeningen met SWAP opnieuw gedaan. Er is rekening gehouden met een verbreding van de bedding tot $12 \mathrm{~m}$ of het afplaggen van het beekdal. De situatie bij de plekken 1 (Roonboom) en 4 (Mepper Hooilanden) worden niet door de maatregelen beïnvloed. Bij de plekken 2 en 3 verandert de drainageweerstand van de beek door verlaging van bedding en peil. Geschat is dat bij plek 2 de bodem en het peil $20 \mathrm{~cm}$ lager, en bij plek $340 \mathrm{~cm}$ lager komt te liggen. Het gaat hier om een grove aanname, een nauwkeuriger inschatting kan pas worden gemaakt aan de hand van de actuele hoogtes en de originele ontwerptekeningen.

De grondwaterstand in de flanken van het beekdal dalen in de nieuwe situatie (figuur 3.13, $2 \mathrm{nw}$ en $3 \mathrm{nw}$ ). De kwel/wegzijging bij 2 verandert nauwelijks, maar bij 3 neemt de wegzijging iets af.

In figuur 3.14 zijn de overschrijdingsduurlijnen van de grondwaterstanden van de huidige en voorgestelde situatie met elkaar vergeleken. Voor plek 2 loopt het aantal dagen dat er (in 2015) inundatie optreedt terug van 163 naar 132 dagen en voor plek 3 van 93 naar 55. De grondwaterstanden dalen minder dan de verdieping van de beekbodem. Bij plek 2 dalen de diepste standen $10 \mathrm{~cm}$ en bij plek $315 \mathrm{~cm}$. Verder van de beek zal de daling minder groot zijn. 


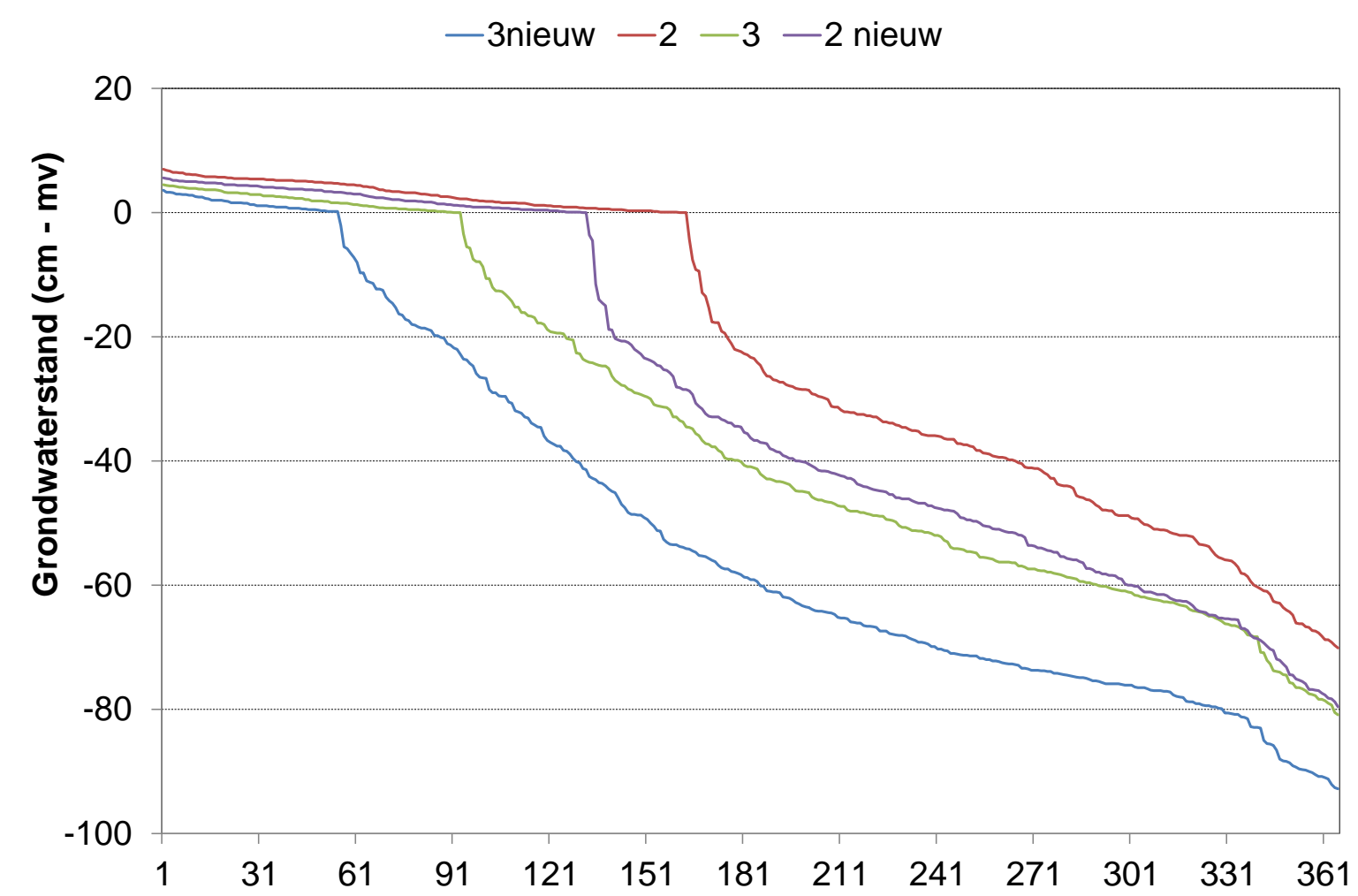

Figuur 3.14 Berekende overschrijdingsduurlijnen van het grondwater bij de plekken 2 en 3 (zie figuur 3.11) in de oude situatie en na verdieping en verbreding van het beekprofiel.

\subsection{Aanbevelingen t.a.v. hydrologische knelpunten}

Er worden twee maatregelpakketten voorgesteld om de wateroverlast bij gemaal Bollema aan te pakken. De maatregelen variëren van het fors wijzigen van het beekprofiel bij geen of beperkte ontwikkeling van moerasbos tot een eenvoudigere aanpassing met een sterke moerasbosontwikkeling.

\section{Omvangrijke aanpassing van het beekprofiel wanneer moerasbos ontbreekt}

Zonder moerasbos is de meest effectieve maatregel het aanpassen van beekprofiel van de Geeserstroom tussen de klepduiker achter gemaal Bollema en de Hamer van Moret. De aanpassing komt neer op beekvolgend vereffenen van het verhang over het hele traject, beginnend bij een hoogte van 13,85 m + NAP bij de klepduiker tot de oorspronkelijke bodemhoogte bij de Hamer van Moret. Daarmee wordt de beek verdiept en een knik in de verhanglijn weggenomen. Tegelijkertijd wordt de beekbedding verbreed van 4 naar $12 \mathrm{~m}$ bij de klepduiker tot de oorspronkelijke $4 \mathrm{~m}$ bij de Hamer van Moret.

De waterstand van de plassen tussen gemaal Bollema en de Geeserstroom zal na verlaging van de waterstand in de Geeserstroom tot het drempelniveau van de duiker dalen.

De waterstanden worden ten opzichte van NAP in het vergraven beektraject lager, maar de beek zal over de volle breedte water blijven voeren. Naast de bredere, watervoerende beekbedding worden de grondwaterstanden in de flanken van het beekdal lager en de periode dat er inundatie optreedt neemt af. Dichter bij de beek en dichter bij Bollema is de daling het grootst. Er is van uitgegaan dat de bedding begroeid raakt met een vegetatie die nu ook aanwezig is, maar er ontstaan wel meer kansen voor de ontwikkeling van een moerasbos. 
Het lagere peil zorgt ervoor dat, met het dichtgroeien van de beek, de bergingscapaciteit weer toeneemt. Tot die tijd zal het debiet bij de Hamer van Moret meer fluctuaties vertonen. De kans neemt toe dat het bergingsgebied Roonboom daadwerkelijk gebruikt wordt. De drempel bij het uitstroompunt van de Marsen naar de Geeserstroom moet eventueel verstevigd worden om te voorkomen dat door uitschuring preferente stroombanen ontstaan. Naarmate de veenvegetatie in de Mepper Hooilanden en in de Marsen zich verder gaat ontwikkelen, zal de capaciteit voor waterberging en sponswerking toenemen.

\section{Aanpassing van het beekprofiel tot een accoladeprofiel bij moerasbos}

Idealiter ontstaat een moerasbos in het beekdal, met weinig ondergroei waardoor het doorstroomprofiel voor de waterafvoer verbetert. In dat geval kan worden volstaan met het opheffen van de knik in het verhang (figuur 3.1), het herstellen van de beekbedding van 4,0 $\mathrm{x}$ 0,4 m tussen Bollema en de Hamer van Moret en het ondiep verbreden (afplaggen) van een zone langs de bedding. Bij een begroeiing die vergelijkbaar is met de huidige vegetatie en een plagdikte van $10 \mathrm{~cm}$ zou een breedte van minimaal $140 \mathrm{~m}$ (en een gelijkmatig verhang) nodig zijn om het peil bij Bollema afdoende te verlagen, maar met weinig ondergroei in het broekbos is een plagzone van $8 \mathrm{~m}$ breed (12 m minus de breedte van de bedding) Bollema en de Hamer van Moret voldoende. Bij het plaggen moet minimaal $10 \mathrm{~cm}$ van de zode worden verwijderd. Afhankelijk van de lokale situatie kan op beide of één van beide oevers worden afgeplagd.

De kans bestaat dat het beekprofiel toch te snel dichtgroeit en de waterstanden te hoog worden voor opgroeiend moerasbos. Dan kan een kleine nevengeul/bypass worden aangelegd om de afvoerpieken te verwerken. In verband met het nodige onderhoud zou de bypass op een goed bereikbare plek moeten komen (langs het fietspad?). De bypass kan worden opgeheven als het bos volgroeid is en de waterafvoer conform de verwachting verloopt.

Omdat de afgeplagde delen bedoeld zijn voor schaduwrijk Elzenbroekbos valt te overwegen om meer dan het noodzakelijk geplande oppervlak af te plaggen. Voor het waterniveau bij Bollema maakt het niet uit of tussen Bollema en de Hamer van Moret of tot nog verder stroomafwaarts tot bijvoorbeeld de Goringdijk wordt afgeplagd.

\subsection{Mepper Hooilanden}

Een apart knelpunt is de Mepper Hooilanden, een plas van ongeveer 30 ha (1000 x 200/400 $\mathrm{m}$ ) die door afgraving is ontstaan. De plas is gegraven met het idee dat die na verloop van tijd zou verlanden. Dat de verlanding van de Mepper hooiplassen niet op gang komt is het gevolg van een te groot wateroppervlak (golfslag), een te diepe bodem en een beperkt doorzicht, ganzenvraat en minimale fluctuaties in waterpeil. De vraag is: hoe kan de verlanding worden gestimuleerd?

Verlagen van het peil is de eenvoudigste en meest doeltreffende oplossing. Hierdoor valt een grotere oeverzone droog en wordt de rest van de plas minder diep. Daarvoor moet de overloop (in stapjes) worden verlaagd.

Als verlaging van het peil geen optie is kan alleen nog de bodem worden verhoogd om de waterdiepte en het wateroppervlak te verminderen, maar dat is veel ingrijpender en minder gewenst t.a.v. de oorspronkelijke doelen van de slenk.

De waterkwaliteit valt op korte termijn niet te verbeteren. Het geringe doorzicht hangt samen met de golfslag en het veen en slib in het bodemmateriaal. Zonder ingrepen, die ook de rest 
van het stroomgebied van de Geeserstroom beïnvloeden, kan de fluctuatie niet worden vergroot.

Een alternatieve optie is het aanleggen van kleine strekdammen. Door de overheersende westenwinden ligt de westoever in de luwte, waar verlanding de meeste kans van slagen heeft. Door de plas te compartimenteren wordt de golfslag minder en komen er meer westoevers. De dijkjes die daarvoor aangelegd moeten worden, steken nauwelijks boven het wateroppervlak uit. Ze hoeven niet bij de oevers te beginnen, maar kunnen als langgerekte eilandje (goede broedplekken) in zw- en nw-richtingen door de plas worden aangelegd. Het materiaal om de dijkjes op te werpen kan uit de directe omgeving worden aangevoerd (gebiedseigen substraat) of ze kunnen uit de plas worden opgespoten. In het laatste geval ontstaan er wat diepere delen in de plas. Die mogen dan niet aan de westzijde van de dijkjes komen te liggen. Op de dijkjes en langs de westoever van de plas kan de verlanding in gang worden gezet door op verschillende plekken helofyten als riet, lisdodde en gele lis aan te planten. Dan zijn wel tijdelijke maatregelen nodig om ganzenvraat tegen te gaan.

\subsection{Aanbevelingen om te komen tot planvorming}

De voorgestelde afvlakking en verbreding van het beekprofiel geeft een globaal inzicht in de gevolgen voor de waterstanden. Voor een verdere uitwerking zijn gegevens nodig van het originele ontwerp van het beekprofiel tussen Bollema en de Hamer van Moret. Het voorgestelde profiel kan dan goed met het oud uitgegraven beekprofiel vergeleken worden. Dat levert tevens inzicht in de hoeveelheid bodemmateriaal en substraat die moet worden verwijderd.

De hydrologie van de Geeserstroom hangt nauw samen met de verspreiding en weerstand (doorlatendheid) van de keileem. Er is al veel onderzoek naar gedaan, maar het verdient aanbeveling om het kaartbeeld te verfijnen zodra er aanvullende gegevens beschikbaar zijn.

De systeembeschrijving en de analyse van gemeten en berekende grondwaterstanden zou aan waarde winnen als meer in detail naar de grond- en oppervlaktewaterstanden wordt gekeken. Daarmee zouden bijvoorbeeld isohypsenbeelden en stijghoogtes boven en onder de keileem kunnen worden samengesteld die een beter beeld geven van de grondwaterstroming onder verschillende omstandigheden. 


\section{Broekbossen in het algemeen}

\subsection{Broekbosvegetaties}

In dit hoofdstuk wordt een algemeen overzicht beschreven van de vegetatiekundige en faunistische variatie binnen moeras- of broekbossen en van de sleutelfactoren die bepalend zijn voor het ruimtelijk voorkomen en het functioneren van broekbossen en voor de variatie in soortensamenstelling. Hiervoor is gebruik gemaakt van informatie uit het preadvies Natte Bossen (Poels et al. 2000), het boek 'Broekbossen' (Stortelder et al. 1998) en het OBN rapport 'Herstel broekbossen'(Runhaar et al. 2013). Voor een overzicht van de sleutelfactoren met betrekking tot broekbossen wordt verwezen naar bijlage 2 en 4 .

\section{Broekbosvegetatie}

Broekbossen zijn ondergebracht in twee aparte klassen: de elzenbroekbossen van de beekdalen en de laagveenmoerassen, en de berkenbroekbossen die vooral te vinden zijn in hoogveengebieden en langs heidevennen (Tabel 4.1). Moerasbossen langs natte beekdalen kunnen nog een derde bostype huisvesten: de wilgenbossen. Van de wilgenbossen betreft het de broekbossen die vooral voorkomen op de lagere delen van de uiterwaarden langs de grote rivieren ("zachthout-ooibos"). Een belangrijk kenmerk van alle drie de broekbostypen is dat slechts enkele boomsoorten onder de heersende, zeer natte omstandigheden kunnen groeien. Het belangrijkste verschil is de dominante boomsoort: in wilgenbossen de smalbladige wilgensoorten, in elzenbos de Zwarte els en in berkenbos de Zachte berk. In overgangen naar andere bostypen, op droger en/of minder venig substraat kunnen andere boomsoorten een rol van betekenis gaan spelen. Op relatief basen- en voedselrijke gronden is dit de Gewone es, aan de voedselarme en zure kant van het ecologisch spectrum vooral Zomereik (Runhaar et al. 2013). Daarnaast verschilt vooral de ondergroei tussen de typen. $\mathrm{Er}$ is geen sprake van een bostype en bosouderdom gebonden ondergroei maar worden meestal lichtminnende plantensoorten aangetroffen in een samenstelling die overeenkomt met korte vegetaties in het aangrenzend moeraslandschap. In het Elzenbroek gaat het dan vooral om soorten van Grote-zeggenvegetaties, Dotterbloem-hooilanden en moerasruigten, in het Berkenbroek om soorten van hoogveenbegroeiingen en natte heide.

De grote overlap in soortensamenstelling tussen moeras-/broekbossen en moerasvegetaties maakt dat er weinig soorten zijn die specifiek gebonden zijn aan broekbossen (Runhaar et al. 2013). Uitzonderingen zijn de Elzenzegge in het elzenbroek en het Gerafeld veenmos (Sphagnum girgensohnii) in het berkenbroek. De samenstelling van de ondergroei wordt vooral bepaald door de milieuomstandigheden ter plaatse en de kolonisatie van soorten uit nabij gelegen moerasvegetaties.

Binnen de broekbossen is de interne variatie aan milieuomstandigheden vaak groot omdat de bodem reliëfrijk is met een afwisseling van natte poelen en kleine, relatief droge plekken rond de boomvoeten. Deze afwisseling aan microhabitats draagt aanzienlijk bij aan de soortenrijkdom.

Tabel 4.1 Voorkomen en belangrijkste soorten van de Elzen- en Berkenbroekbossen (Runhaar et al. 2013).

\begin{tabular}{|l|l|l|l|l|}
\hline Hoofdgroep & $\begin{array}{l}\text { Ken- en differen- } \\
\text { tiërende soorten } 1)\end{array}$ & \multicolumn{2}{|l|}{ Constante soorten ${ }^{2)}$} & \multirow{2}{*}{ Landschap } \\
\cline { 3 - 4 } & Boom- en & Kruid- en moslaag & \\
\hline
\end{tabular}




\begin{tabular}{|l|l|l|l|l|}
\hline & & struiklaag & & \\
\hline $\begin{array}{l}\text { Elzenbroekbos } \\
\text { (klasse 39: Alnetea } \\
\text { glutinosae) }\end{array}$ & $\begin{array}{l}\text { Zwarte els (k), } \\
\text { Hennegras } \\
\text { Grauwe wilg, Gele lis } \\
\text { Bitterzoet, Grote } \\
\text { wederik, } \\
\text { Grote kattestaart, } \\
\text { Wolfspoot, Melkeppe, } \\
\text { Gewoon puntmos }\end{array}$ & Zwarte els & $\begin{array}{l}\text { Hennegras, Gele lis, } \\
\text { Gewoon sterremos, } \\
\text { Bitterzoet, Grote } \\
\text { wederik }\end{array}$ & $\begin{array}{l}\text { Zwaartepunt in: } \\
\text { Beekdalen } \\
\text { Laagveengebieden }\end{array}$ \\
$\begin{array}{l}\text { Berkenbroekbos } \\
\text { (klasse 40: Vaccinio- } \\
\text { petuletea } \\
\text { pubescentis) }\end{array}$ & $\begin{array}{l}\text { Zachte berk (k), } \\
\text { Gerafeld veenmos (k), } \\
\text { Slank veenmos, } \\
\text { Veen-knopjesmos, } \\
\text { Veenpluis }\end{array}$ & Zachte berk & $\begin{array}{l}\text { 3) (Pijpenstrootje, } \\
\text { Gewone dophei) }\end{array}$ & $\begin{array}{l}\text { Zwaartepunt in: } \\
\text { Hoogvenen } \\
\text { Natte heidegebieden }\end{array}$ \\
& & & & $\begin{array}{l}\text { Minder algemeen in: } \\
\text { Verdroogde } \\
\text { beekdalen met } \\
\text { voedselarme } \\
\text { kwel; } \\
\text { Geïsoleerde } \\
\text { beekdalen; } \\
\text { Kraggen in diepe } \\
\text { veenplassen. }\end{array}$ \\
\hline
\end{tabular}

1) (k): kensoort van de klasse; overige: differentiërend t.o.v. andere bosklassen; 2) Presentie > 60\%; 3) geen enkele soort in de ondergroei haalt een presentiewaarde van $60 \%$ of meer; dit is een gevolg van de grote verschillen in soortensamenstelling binnen de klasse van de berkenbroekbossen (zie toelichting in tekst).

\section{Elzenbroekbossen}

Het belangrijkste type broekbos van de beekdalen is het Elzenzegge-Elzenbroek (Carici elongatae-Alnetum) met Elzenzegge als enige kensoort en Grote wederik en Gele lis als meest algemene begeleidende soorten. Buiten de beekdalen komt deze associatie slechts heel sporadisch voor.

Binnen het Elzenzegge-Elzenbroek kunnen verschillende varianten worden onderscheiden (Stortelder et al. 1998, 1999)(tabel 4.2). Er kan een reeks worden onderscheiden op basis van mate en frequentie van inundatie die loopt van de subassociatie van Bittere veldkers natte plekken met nauwelijks dynamiek en met een relatief gunstige basenvoorziening, via de subassociatie van Zomprus op natte plekken met weinig dynamiek vooral in bovenlopen (is een overgang naar het berkenbroek), via de typische, soortenrijke subassociatie in natte middenlopen van beekdalen met kwelinvloed, naar de subassociatie van Zwarte bes in benedenlopen met meer dynamiek. Bij verdroging treedt tenslotte de subassociatie van Framboos naar voren. Bij sterkere verdroging, al dan niet in combinatie met eutrofiëring, treden, in volgorde van toenemende voedselrijkdom, elzenbroekbossen op die worden gedomineerd door Hennegras, Gewone braam en Grote brandnetel (tabel 4.2)(Runhaar et al. 2013). Bij ontwikkeling van "nieuw" broekbos door vernatting van voormalige landbouwgronden en gronden waar periodiek overstroming met eutroof beekwater optreedt, is het optreden van een langdurige brandnetelfase aannemelijk. Op permanent natte standplaatsen of plekken die regelmatig inunderen kan de brandnetel zich niet handhaven (Tickner et al. 2001, Siebel 1998). Bij nieuwvorming van broekbos in beekdalen in niet sterk geëutrofieerd, kwelrijk milieu is het optreden van een tijdelijke fase met dominantie van Moeraszegge te verwachten (Runhaar et al. 2013).

Tabel 4.2 Broekbostypen kenmerkend voor beekdalen. Indeling tenzij anders vermeld volgens Stortelder et al. (1999).

\begin{tabular}{|l|l|l|l|}
\hline Bostype & Kenmerkende soorten ${ }^{\mathbf{1}}$ & Constante soorten $^{\mathbf{2}}$ & Groeiplaats $^{\mathbf{3}}$ \\
\hline Elzenbroekbos, goed ontwikkelde vormen & Bitterzoet, Elzenzegge, Gele & Natte beekdalen met \\
\hline 39Aa2a Elzenzegge- & Stijve zegge, Hoge
\end{tabular}




\begin{tabular}{|c|c|c|c|}
\hline $\begin{array}{l}\text { Elzenbroek (typische vorm) } \\
\text { Carici elongatae-Alnetum } \\
\text { typicum }\end{array}$ & cyperzegge & $\begin{array}{l}\text { lis, } \\
\text { Grote wederik, Wolfspoot, } \\
\text { Zwarte els }\end{array}$ & $\begin{array}{l}\text { kwelinvloed, vnl. } \\
\text { middenlopen; minder } \\
\text { wisselende } \\
\text { waterstanden }\end{array}$ \\
\hline $\begin{array}{l}\text { 39Aa2c Zwarte bes- } \\
\text { Elzenbroek } \\
\text { Carici elongatae-Alnetum } \\
\text { ribetosum nigrae }\end{array}$ & $\begin{array}{l}\text { Zwarte bes (met hoge } \\
\text { bedekking) }\end{array}$ & $\begin{array}{l}\text { Bitterzoet, Echte valeriaan, } \\
\text { Elzenzegge, Fijn snavelmos, } \\
\text { Gele lis, Grote brandnetel, } \\
\text { Grote wederik, Hop, } \\
\text { Moerasspiraea, } \\
\text { Moeraswalstro, Pitrus, Ruw } \\
\text { beemdgras, Zwarte bes, } \\
\text { Zwarte els }\end{array}$ & $\begin{array}{l}\text { Natte beekdalen, vnl. } \\
\text { benedenlopen van } \\
\text { beekdalen; inundaties } \\
\text { treden op; meer } \\
\text { wisselingen in } \\
\text { waterstand }\end{array}$ \\
\hline $\begin{array}{l}\text { 39Aa2e Zomprus- } \\
\text { Elzenbroek } \\
\text { Carici elongatae-Alnetum } \\
\text { caricetosum curtae }\end{array}$ & $\begin{array}{l}\text { Zachte berk, Zompzegge, } \\
\text { Moerasstruisgras, } \\
\text { Wateraardbei }\end{array}$ & $\begin{array}{l}\text { Gewoon sterremos, Grote } \\
\text { wederik, } \\
\text { Hennegras, Melkeppe, Pitrus, } \\
\text { Smalle stekelvaren, Zachte } \\
\text { berk, Zompzegge, Zwarte els }\end{array}$ & $\begin{array}{l}\text { Geïsoleerde beekdalen } \\
\text { en bovenlopen; weinig } \\
\text { waterstandsdynamiek; } \\
\text { lichte verzuring }\end{array}$ \\
\hline $\begin{array}{l}\text { 39Aa2b Veldkers- } \\
\text { Elzenbroek } \\
\text { Carici elongatae-Alnetum } \\
\text { cardaminetosum amarae }\end{array}$ & $\begin{array}{l}\text { Bittere veldkers, Kruipende } \\
\text { boterbloem, Bosbies, } \\
\text { Verspreidbladig goudveil, } \\
\text { Paarbladig goudveil, Groot } \\
\text { springzaad }\end{array}$ & $\begin{array}{l}\text { Bittere veldkers, Gele lis, } \\
\text { Grote brandnetel, Kruipende } \\
\text { boterbloem, Moerasspiraea, } \\
\text { Moeraswalstro, Zwarte els }\end{array}$ & $\begin{array}{l}\text { Natte, kwelrijke } \\
\text { beekdalen; laag } \\
\text { dynamisch; gunstige } \\
\text { basenvoorziening }\end{array}$ \\
\hline $\begin{array}{l}\text { 39Aa2d Frambozen- } \\
\text { Elzenbroek } \\
\text { Carici elongatae-Alnetum } \\
\text { rubetosum idaei }\end{array}$ & $\begin{array}{l}\text { Framboos, Wilde } \\
\text { kamperfoelie, Ruwe smele, } \\
\text { Rankende helmbloem }\end{array}$ & $\begin{array}{l}\text { Framboos, Gewone braam, } \\
\text { Hennegras, Smalle } \\
\text { stekelvaren, Vogelkers, Wilde } \\
\text { kamperfoelie, Wilde lijsterbes, } \\
\text { Zachte berk, Zwarte els }\end{array}$ & $\begin{array}{l}\text { Licht verdroogde } \\
\text { beekdalen }\end{array}$ \\
\hline \multicolumn{4}{|c|}{ Elzenbroekbos, rompgemeenschappen } \\
\hline $\begin{array}{l}\text { Hennegras-Elzenbroek } \\
R G \text { Calamagrostis canescens }\end{array}$ & $\begin{array}{l}\text { Hennegras (met hoge } \\
\text { bedekking) }\end{array}$ & $\begin{array}{l}\text { Gewone braam, Hennegras, } \\
\text { Zwarte els }\end{array}$ & $\begin{array}{l}\text { Verdroogde beekdalen, } \\
\text { soms nog met } \\
\text { (voedselarme) kwel } \\
\text { maar dan sterk } \\
\text { begreppeld }\end{array}$ \\
\hline $\begin{array}{l}\text { Braam-Elzenbroek } \\
R G \text { Rubus fruticosus }\end{array}$ & $\begin{array}{l}\text { Gewone braam (met hoge } \\
\text { bedekking) }\end{array}$ & $\begin{array}{l}\text { Bitterzoet, Brede stekelvaren, } \\
\text { Gele lis, Gewone braam, } \\
\text { Hennegras, Hop, Wilde } \\
\text { lijsterbes, Zwarte els }\end{array}$ & $\begin{array}{l}\text { Verdroogde beekdalen } \\
\text { (voedselrijk[rijker dan } \\
\text { vorige type]) }\end{array}$ \\
\hline $\begin{array}{l}\text { Brandnetel-Elzenbroek } \\
\text { RG Urtica dioica }\end{array}$ & $\begin{array}{l}\text { Grote brandnetel (met hoge } \\
\text { bedekking) }\end{array}$ & $\begin{array}{l}\text { Gele lis, Gewone braam, } \\
\text { Grote brandnetel, Hop, Ruw } \\
\text { beemdgras, } \\
\text { Zwarte els }\end{array}$ & $\begin{array}{l}\text { Verdroogde beekdalen } \\
\text { (geëutrofieerd; nog } \\
\text { rijker dan vorige type); } \\
\text { minder periodieke } \\
\text { inundatie met eutroof } \\
\text { beekwater kan }\end{array}$ \\
\hline $\begin{array}{l}\text { Moeraszegge-Elzenbroek } \\
R G \text { Carex acutiformis }\end{array}$ & $\begin{array}{l}\text { Moeraszegge (met hoge } \\
\text { bedekking) }\end{array}$ & $\begin{array}{l}\text { Bitterzoet, Gewoon sterremos, } \\
\text { Moeraszegge, Smalle } \\
\text { stekelvaren, Zwarte els }\end{array}$ & $\begin{array}{l}\text { Kwelrijke beekdalen; } \\
\text { meer lichtinval na kap } \\
\text { of jong }\end{array}$ \\
\hline \multicolumn{4}{|l|}{ Berkenbroekbos } \\
\hline $\begin{array}{l}\text { Zompzegge-Berkenbroek } \\
\text { (typische vorm) } \\
\text { Carici curtae-Betuletum } \\
\text { typicum }\end{array}$ & $\begin{array}{l}\text { Gewimperd veenmos, } \\
\text { Gewoon haarmos, } \\
\text { Gewoon veenmos, Riet, } \\
\text { Slank veenmos, Veen- } \\
\text { knopjesmos, Zachte berk }\end{array}$ & $\begin{array}{l}\text { Zachte berk, Zwarte els, } \\
\text { Gewimperd veenmos, Riet, } \\
\text { Gewoon sterremos }\end{array}$ & $\begin{array}{l}\text { Geïsoleerde beekdalen } \\
\text { Verdroogde beekdalen } \\
\text { met voedselarme kwel }\end{array}$ \\
\hline
\end{tabular}

1) Differentiërend ten opzichte van overige subassociaties; 2) Presentie $>60 \%$; 3) indeling naar Stortelder et al., 1998.

\section{Berkenbroekbossen}

Berkenbroekbossen spelen in de beekdalen een ondergeschikte rol en ontstaan vooral in situaties waarin sprake is van een (toenemende) invloed van regenwater op de samenstelling van het grondwater. Dit betreft vaak bovenlopen of afgesneden laagtes. Waar 
het voorkomt, betreft het steeds de typische subassociatie van het Zompzegge-Berkenbroek (Carici curtae-Betuletum pubescentis typicum). Differentiërend ten opzichte van de beekdalelzenbroekbossen zijn Gewimperd veenmos, Gewoon haarmos, Gewoon veenmos, Riet, Slank veenmos, Veen-knopjesmos en Zachte berk. Ook kan Berkenbroekbos opslaan in verdroogd, voedselarm elzenbroek na kap van de Elzen. Het nieuw ontstane Berkenbroek behoort weliswaar tot het Zompzegge-Berkenbroek, maar is veelal slecht ontwikkeld en kan zich bij voortgaande verdroging ontwikkelen in de richting van een vochtig Berken-Eikenbos (Betulo-Quercetum roboris)(Runhaar et al. 2013).

\section{Naar een samenhangend beeld van broekbossen in beekdalen}

De belangrijkste indelingen van broekbossen zijn die van van der Werf (1991) en Runhaar et al. (2013). De laatste indeling sluit direct aan op de 'Vegetatie van Nederland'. Op basis van gemiddelde grondwaterstand en voedselrijkdom is voor de in beekdalen relevante broekbostypen een samenhang gemaakt (figuur 4.1). Met dit schema is het mogelijk de broekbossen die in het dal van de Geeserstroom te verwachten zijn in te vullen.

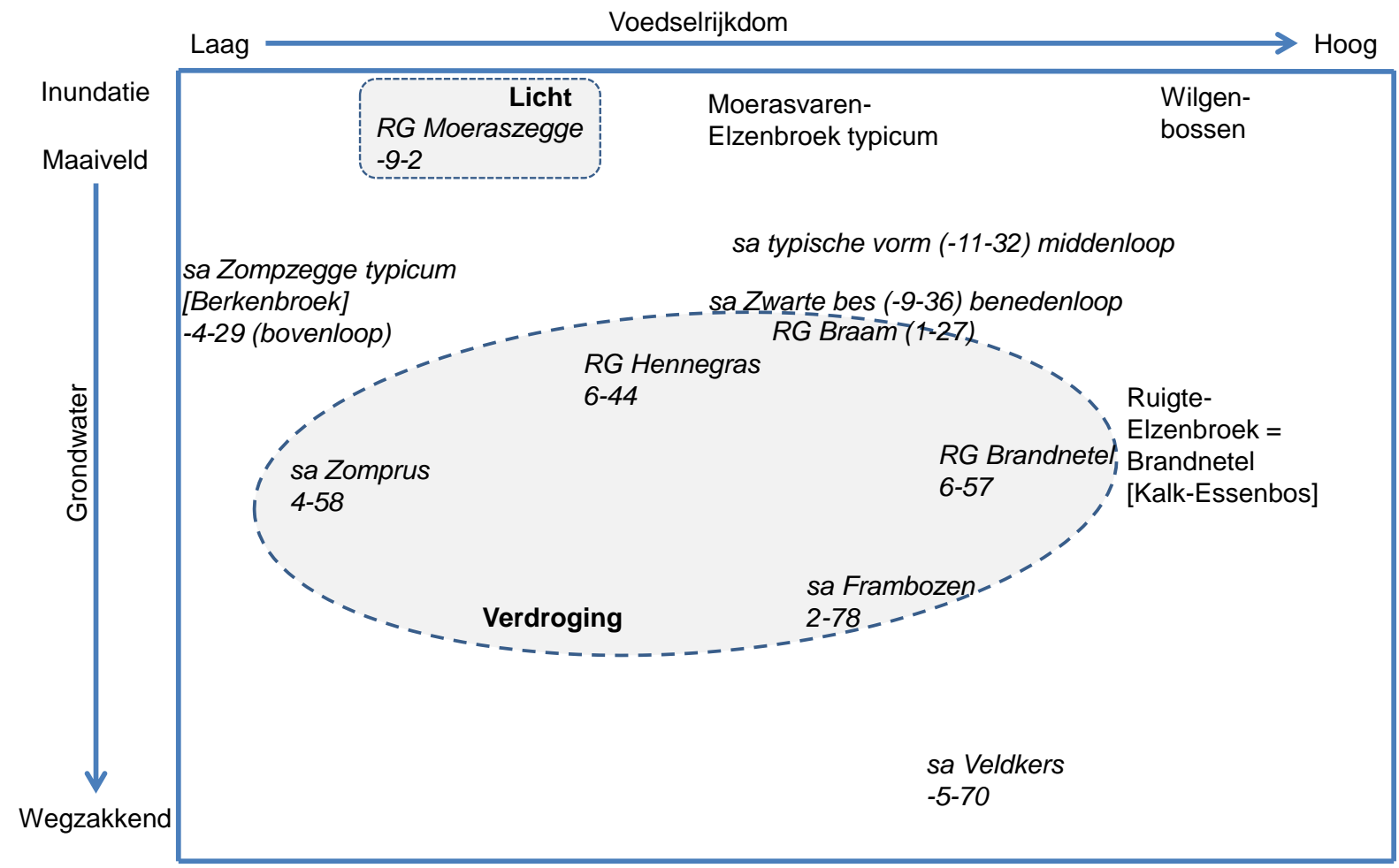

Figuur 4.1 Samenhang tussen de verschillende voor beekdalen relevante broekbossen.(cijfers GHG, $R G$ = rompgemeenschap, sa = subassociatie)

Ook de wilgenbossen kunnen in een onderling verband worden geplaatst (figuur 4.2). 


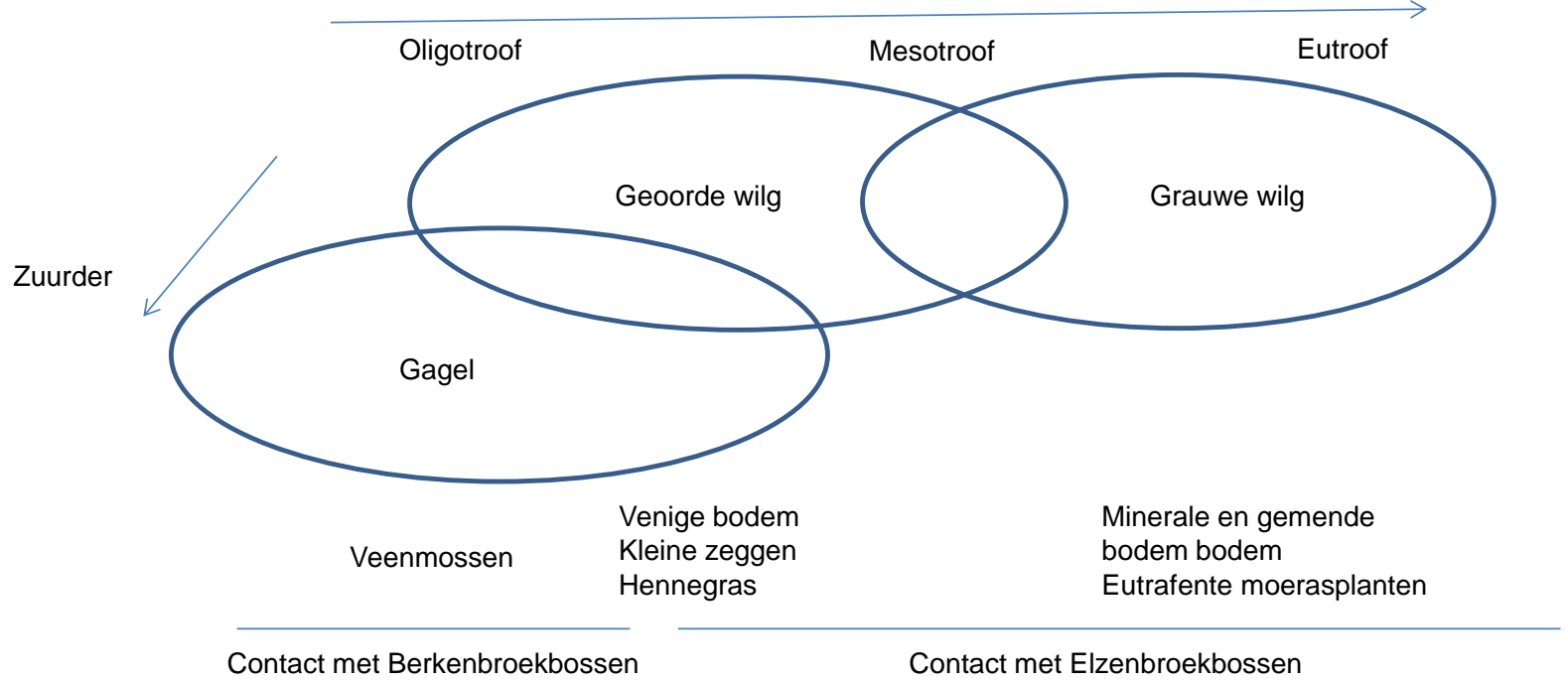

Figuur 4.2 Samenhang tussen de wilgenbossen en het gagelstruweel (naar De Fré \& Hoffmann 2002).

\subsection{Broekbosfauna}

Ongewervelden vormen verreweg de meest diverse en talrijke groep macro-organismen binnen de broekbosfauna omdat 1) ongewervelden een grote rol spelen in het functioneren, 2) ongewervelden zeer indicatief kunnen zijn voor de heersende milieufactoren op microschaal, waardoor ook kleinschalige gradiënten in milieuomstandigheden kunnen worden vastgesteld, en 3) bosfragmenten nog steeds een aanzienlijk aantal karakteristieke ongewervelden kunnen bevatten, omdat evertebraten door hun geringe grootte simpelweg minder oppervlakte nodig hebben om te kunnen overleven.

Voor de fauna zijn binnen niet verdroogde moeras- of broekbossen grofweg twee groepen van belang: broekbossen in natte beekdalen, waarbij zowel inundatie met kwelwater als met beekwater plaatsvindt (zie o.a. Wright et al. 2002) en broekbossen in kwelrijke beekdalen en laagtes in het dekzandgebied, die nooit of vrijwel nooit overstromen met beekwater en alleen gevoed worden door kwelwater (tabel 4.3).

De bewoners van broekbossen hebben verschillende aanpassingen en overlevingsstrategieën om hun levenscyclus te kunnen voltooien in deze systemen. Aanpassingen zijn noodzakelijk omdat de specifieke milieuomstandigheden in broekbossen (o.a. inundatie, droogval, zuurstofloosheid) zorgen voor verschillende ecologische knelpunten.

Tabel 4.3 Onderscheid in hydrologische broekbostypen relevant voor soortensamenstelling fauna.

\begin{tabular}{lll}
\hline & Kwel- en oppervlaktewater & Alleen kwelwater \\
\hline Inundatieduur & Maanden in winter, dagen in & Maanden in winter \\
Voorspelbaarheid inundatieperiode & $\begin{array}{l}\text { Deels voorspelbaar (winter) } \\
\text { deels onvoorspelbaar (zomer) }\end{array}$ & Voorspelbaar \\
& $\begin{array}{l}\text { Jaarrond mogelijk } \\
\text { Fenologie inundatie }\end{array}$ & Winterhalfjaar \\
Herkomst water & Grond- en beekwater & Grondwater \\
Waterbeweging & Stroming mogelijk & Stagnant \\
Maximale diepte grondwater bij & $\pm 30-60 \mathrm{~cm}$ diep & $\pm 5-30 \mathrm{~cm}$ diep \\
droogte & & \\
\hline
\end{tabular}


Op basis van de plek waar de ongewerveldenfauna in een broekbos haar levenscyclus doorloopt kan een onderverdeling worden gemaakt in vier groepen ongewervelden binnen het systeem:

1. Aquatische fauna van inundatiezones en (rest)poelen.

2. (Semi-)terrestrische fauna, die leeft op en in de strooisellaag van de niet met water verzadigde bosbodem.

3. Fauna van de met water verzadigde bosbodem.

4. Fauna van de kruiden, struiken en bomen in het broekbos.

Daarbij heeft de fauna om te kunnen overleven in broekbossen aanpassingen aan de belangrijke sturende factoren (figuur 4.3).

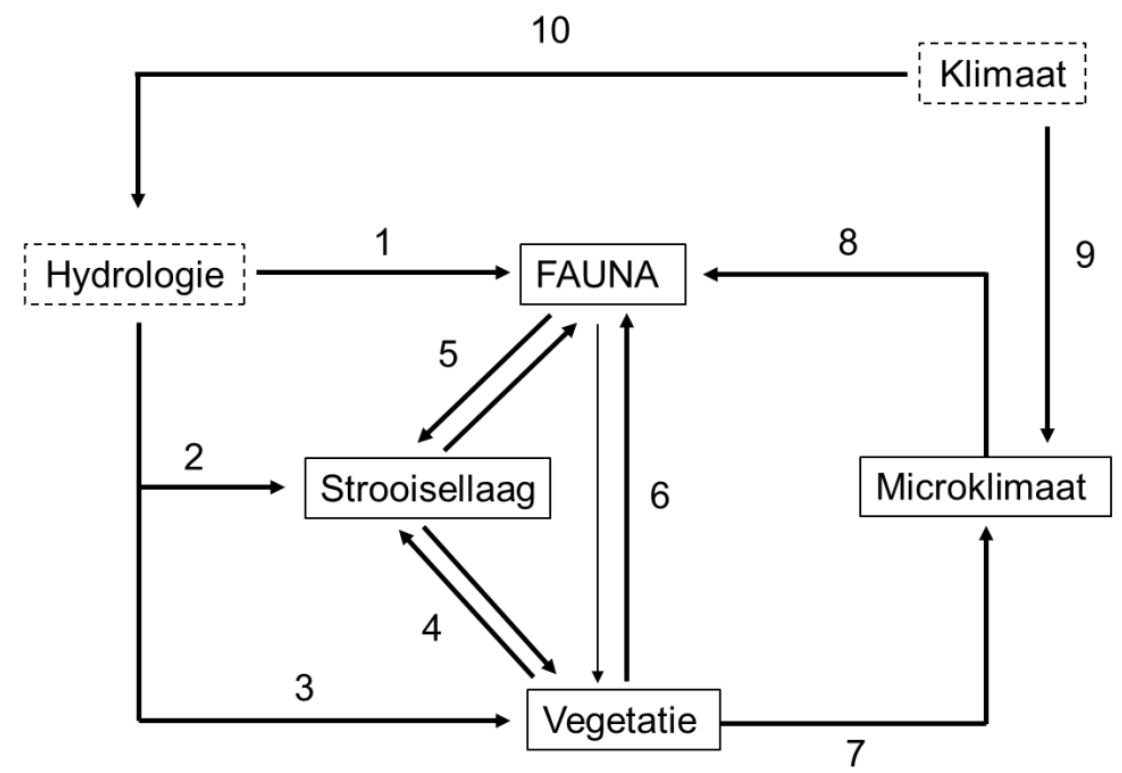

1. Duur, fenologie, voorspelbaarheid inundatie; 2. Invloed inundatie op strooiselafbraak; 3. Invloed inundatie op vegetatiesamenstelling; 4 . Strooiselproductie door vegetatie en vrijkomen van voedingstoffen voor vegetatie bij afbraak; 5. Strooisel als voedsel en schuilplaats voor fauna en omzetting van strooisel door fauna; 6 . Vegetatiestructuur, zuurstofproductie en verandering hiervan door herbivorie; 7 . Invloed van vegetatie op microklimaat; 8. Temperatuur, zoninstraling; 9. Klimatologische omstandigheden 10. Neerslagpatroon.

Figuur 4.3 Sturende factoren voor de aquatische en semi-terrestrische fauna van broekbossen. Dikte van de pijlen geeft de mate van relevantie van de relatie weer. Klimaat en hydrologie spelen op een hoog landschappelijk schaalniveau, terwijl de andere componenten zich afspelen op kleinere schaal (Runhaar et al. 2013).

Verreweg de belangrijkste sturende factor is het hydrologische regime van het broekbos en de indirecte effecten hiervan op bijvoorbeeld de zuurstofbeschikbaarheid. Daarnaast spelen ook het microklimaat, de bodemmorfologie en de habitatstructuur een rol (figuur 4.3 en paragraaf 4.3)(Runhaar et al. 2013).

\section{Karakteristieke fauna}

Bij de fauna van de niet met water verzadigde bosbodem is vooral gekeken naar loopkevers en spinnen. Er zijn geen soorten loopkevers en spinnen die alleen voorkomen in elzenbroekbossen. Wel typisch voor een goed ontwikkeld nat elzenbroekbos is een hoog 
aandeel vochtminnende (hygrofiele) en lichtschuwe soorten (Nötzold 1996; Stańska et al. 2002, Stańska 2007). Voor groepen zoals landslakken en duizendpoten lijkt een vergelijkbaar beeld naar voren te komen (Berg \& Evenhuis 2001; Vercoutere 2002; Boesveld 2005; Tajovský \& Wytwer 2009).De samenstelling van de gemeenschappen vertoont, afhankelijk van de onderzochte taxonomische groep, overlap met enerzijds andere (vochtige) bostypen en anderzijds moerasvegetaties en natte graslanden (Aggenbach et al. 2014; Runhaar et al. 2013).

Bij toenemende verdroging degradeert het broekbos (Nötzold 1996) wat tot uiting komt in de groepen loopkevers, kortschildkevers en spinnen. Hierbij is een in een sterke toename van eurytope (bos)soorten ten opzichte van de hygrofiele moerassoorten waargenomen (Maelfait et al. 1995; Nötzold 1996; Stańska 2007). In natte broekbossen domineren de hygrofiele moerassoorten, terwijl in vochtige broekbossen eurytope bossoorten overheersen. Een sterke toename van mierensoorten duidt ook op verdroging; natte elzenbroekbossen zijn arm aan mieren door de sterke beschaduwing en een gebrek aan geschikte nestplaatsen in de natte bodem (Wlodarczyk, 2010).

In de met water verzadigde bosbodem vormen de wormen de meest in het oog springende groep (o.a. Beylich \& Graefe 2002). Sommige soorten leven alleen in het bovenste gedeelte van de met water verzadigde bodem (bijv. Eiseniella tetraedra, Cognettia glandulosa), waar voldoende zuurstof kan doordringen, terwijl andere soorten (bijv. Octolasion tyrtaeum tyrtaeum) bestand zijn tegen een lage zuurstofbeschikbaarheid. Deze laatste groep kan ook wat dieper in de bodem voorkomen, maar echt diep gravende soorten komen niet in broekbossen voor. Echter, specifiek voor elzenbroekbossen zijn deze wormen niet; ze komen in allerlei vochtige habitats voor (Runhaar et al. 2013).

Het aantal echte aquatische soorten dat in broekbossen kan voorkomen is beperkt in vergelijking met andere watertypen (Sharitz \& Batzer 1999). Toch zijn een aantal groepen bijzonder succesvol, met name diverse muggen- en vliegenfamilies (circa $75 \%$ van de totale abundantie insecten in Zweedse elzenbroekbossen; Persson Vinnersten et al. 2010). Vooral steek- en vedermuggen spelen een belangrijke rol (Moller Pillot 1984; Schäfer et al. 2008; Verdonschot ongepub. data; Lundkvist et al. 2003). Andere qua abundantie belangrijke groepen muggen zijn de langpoot-, stelt- en meniscusmuggen (Tipulidae, Limnoniidae en Dixidae) (Rief 1996; Disney 1999), de kokerjuffers (Higler, 2008; Van der Hoek \& Cuppen 1989; Móra et al. 2004) en de echte waterkevers zoals de Dytiscidae,Hydrophilidae en Scirtidae (Wissinger 1999; Wiggins et al. 1980; Williams 2005).

Verder kunnen op geïnundeerde plekken Ceratopogonidae, Dixidae, Psychodidae en Ptychopteridae gevonden worden. Hoe succesvol de aquatische ongewervelden van de verschillende groepen zijn in een broekbos hangt sterk af van de inundatieduur, en dan met name de timing van het begin en het einde van de inundatieperiode (Wissinger, 1999; Williams 2005). De hoogste soortenrijkdom in tijdelijke wateren wordt bereikt bij een inundatieperiode van 150 tot 250 dagen (Williams 2005). Des te langer in het voorjaar water beschikbaar is, des te meer aquatische soorten er in staat zijn hun levenscyclus te voltooien. Hiermee is de samenstelling van de aquatische fauna, en vooral de vedermuggen, een zeer goede indicator voor het hydrologische regime van het broekbos (Runhaar et al. 2013).

Naast de broekbosbodemfauna zijn er ook veel soorten te vinden in de kruid-, struiken boomlaag van het broekbos (Ambsdorf 1996; Ścibior \& Dunus 2006). De boomkruinen zijn een voorspelbaar en stabiel habitat ten opzichte van de bodem, zonder bijvoorbeeld de grote veranderingen geïnduceerd door het hydrologische regime of andere milieuvariabelen (Runhaar et al. 2013). Groot verschil met de bodemfauna is een relatief groot aandeel 
herbivoren (bladeters, sapzuigers, mineerders, galvormers). Veel soorten voeden zich met elzen of wilgen, vooral in de randzones (Ambsdorf, 1996).

Het hele jaar zijn er zoogdieren in het broekbos aan te treffen, maar de soortensamenstelling en abundantie wisselt sterk in de tijd. Voor de meeste soorten is het broekbos slechts een van de landschapselementen waar gebruik van gemaakt wordt (Dobrowolski et al. 1993). Echter, twee zoogdieren verdienen door hun levenswijze speciale aandacht: de waterspitsmuis (Neomys fodiens) en de bever (Castor fiber). De waterspitsmuis leeft langs beken en in de aanliggende broekbossen. Deze spitsmuis leeft langs de waterlijn en voedt zich met (semi-)terrestrische ongewervelden, maar jaagt ook wel in het water op aquatische macrofauna (Churchfield \& Rychlik 2006). De soort heeft diverse aanpassingen aan het aquatische milieu, zoals stijve haren aan poten en staart en een speciale samenstelling van de vacht. De bever kan beschouwd worden als een zogenoemde 'ecosystem engineer' en kan een sleutelrol vervullen bij het ontstaan van broekbossen (Wright et al. 2002). Het afdammen van beken door bevers kan leiden tot grootschalige inundaties binnen het beekdal, die kunnen leiden tot het ontstaan van broekbossen. Echter, bij langdurige of permanente inundaties wordt de vorming van wilgenbossen in de hand gewerkt, omdat deze omstandigheden weinig geschikt zijn voor elzen (Runhaar et al. 2013).

Open broekbosdelen vormen ook een belangrijke biotoop voor de zeldzame amfibiesoorten Alpenwatersalamander (Triturus alpestris), Vinpootsalamander (Triturus helveticus), Vuursalamander (Salamandra salamandra) en Boomkikker (Hyla arborea) (http://www.natuurkennis.nl/index.php?hoofdgroep=2\&niveau=3\&subgroep=113\&subsubgroe $\mathrm{p}=1036$ \&subsubsubgroep $=90$ ).

\section{Vogels van beekmoerassen}

Voor vogels zijn elzenbroekbossen een belangrijk habitat, maar er zijn geen vogelsoorten die typisch zijn voor dit habitattype. Desondanks komen er veel vogelsoorten voor, zowel als broedvogel, doortrekker en overwinteraar. Het grootste gedeelte van de soorten zijn bosvogels; moerasvogels komen relatief weinig voor in broekbossen, zelfs als aangrenzend aan het bos open moerasgebieden liggen (Dobrowolski et al. 1993). Wesołowski et al. (2006) beschrijven de vogelstand van een oud, goed ontwikkeld elzenbroekbos van 25 hectare op basis van 30 jaar monitoring in het Białowieża nationaal park, Polen. Op deze locatie werden de volgende broedvogels waargenomen met een dichtheid $>1$ paar per hectare: Vink, Roodborst, Tjiftjaf, Zwartkop, Zanglijster, Merel, Pimpelmees, Koolmees, Heggenmus, Appelvink, Winterkoning, Fluiter, Goudhaan, Bonte Vliegenvanger, Houtduif, Boomklever, Boomkruiper, Zwarte Mees, Grauwe vliegenvanger, Grote bonte specht, Middelste Bonte specht en Glanskop. Vertaald naar de Nederlandse situatie is dit een goed ontwikkelde bosvogelgemeenschap (Runhaar et al. 2013). Broekbossen zijn in het algemeen minder toegankelijk, zodat ze een rustig milieu vormen voor dieren, in het bijzonder voor vogels. Voor overwinterende vogelsoorten als Sijs en Barmsijs zijn broekbossen belangrijke foerageerbiotopen. Daarnaast broeden er soorten als Nachtegaal, Zwartkop en Bosrietzanger. Natuurlijke migratie van zoogdieren, vogels, amfibieën en vele insectensoorten (vooral die waarvan het larvale stadium zich in het water afspeelt) verloopt voornamelijk via de relatief beschutte beekdalen zodat broekbossen ook voor veel diersoorten van belang zijn als "stepping stones" (Natuurbeschermingscommissie 1989).

Er zijn geen vogelsoorten die uitsluitend voorkomen in broekbossen, maar deze bossen leveren wel nestgelegenheid en voedsel aan een groot aantal moeras- en bosvogels. In het winterhalfjaar kunnen wij bijvoorbeeld van de Sijs (Carduelis spinus) grote groepen 
zien foerageren op de elzenproppen. De broedvogeldichtheid is hoog en de samenstelling van de broedvogelpopulatie hangt nauw samen met de bosstructuur. Zo zijn wat grotere opengewaaide of open gekapte delen geschikt voor Houtsnip (Scolopax rusticola) en Waterral (Rallus aquaticus), jonge bosgedeelten voor Sprinkhaanzanger (Locustella naevia) en Kleine karekiet (Acrocephalus scirpaceus) en oude bosgedeelten voor Wielewaal (Oriolus oriolus) en Sperwer (Accipiter nisus). Een afwisselende bosstructuur biedt mogelijkheden voor Nachtegaal (Luscinia megarhynchos) en Appelvink (Coccothraustes coccothraustes).

Wanneer we kijken naar de vogelgemeenschappen dan zullen de volgende groepen in het gebied belangrijker worden:

Rondom de beek vertegenwoordigers uit de IJsvogel-groep: IJsvogel en Grote Gele Kwikstaart?

In het natte overjarige rietland vertegenwoordigers uit de Roerdomp-groep: Roerdomp, Woudaapje Snor, Kleine Karekiet, Grote Karekiet, Baardmannetje.

In het nat tot verlandend zegge-riet vertegenwoordigers uit de Rietzanger-groep: Bruine Kiekendief, Waterral, Rietzanger, Rietgors.

In ondiepe, natte, lage vegetaties (vnl. zeggen; incl. gemaaid riet) vertegenwoordigers uit de Porseleinhoen-groep: Porseleinhoen, Klein Waterhoen en Kleinst Waterhoen, Watersnip.

In verlande rietvegetaties met struiken vertegenwoordigers uit de Blauwborst-groep: Blauwborst en Sprinkhaanzanger.

In natte rietvegetaties vertegenwoordigers uit de groep van Waterrietvogels: Roerdomp, Woudaapje, , Bruine Kiekendief, Waterral, Porseleinhoen, Klein Waterhoen, Kleinst Waterhoen, Watersnip, Snor, Rietzanger, Kleine Karekiet, Grote Karekiet, Baardmannetje, Rietgors.

In de ruigten vertegenwoordigers van de Fazant-groep: Fazant, Graspieper, Paapje,. In veelal nat tot vochtige ruigtes en lage struwelen vertegenwoordigers van de Rietgorsgroep: Blauwborst, Paapje, Sprinkhaanzanger, Rietgors.

In struwelen, opslag en zeer jong bos, bosranden met struiken vertegenwoordigers van de Grasmus-groep: Heggemus, Nachtegaal, Roodborsttapuit, Bosrietzanger, Spotvogel, Braamsluiper, Grasmus, Tuinfluiter, Fitis, Grauwe Klauwier, Kneu.

In jong bos en de struiklaag in bossen vertegenwoordigers van de Winterkoning-groep: Fazant, Zomertortel, Winterkoning, Roodborst, Merel, Zanglijster, Zwartkop, Staartmees, Matkop, Goudvink.

In boomgroepen in rietland en rivierbegeleidend bos vertegenwoordigers van de Buidelmees-groep: Blauwe Reiger Zwarte Wouw Cetti's Zanger, Buidelmees,. In bomen en boomgroepen met struwelen, bosranden, (vrij) voedselrijk vertegenwoordigers van de Putter-groep: Ekster, Zwarte Kraai, Groenling, Putter. In open gebied met bos vertegenwoordigers van de Torenvalk-groep: Torenvalk, Boomvalk, Roek.

\section{Overige organismegroepen in broekbossen}

Broekbossen, en dan vooral elzenbroekbossen, zijn van groot belang voor de mycoflora. $\mathrm{Er}$ zijn vele tientallen soorten paddenstoelen die karakteristiek zijn voor elzenbroekbossen, waaronder veel soorten die strikt aan elzenbomen gebonden zijn (Stortelder et al. 1998, Arnolds en Veerkamp, 2008). De soortenrijkdom in elzenbroekbossen is groot: Bij onderzoek in proefvlakken van $1000 \mathrm{~m}^{2}$ zijn tussen de 100 en 150 soorten aangetroffen (Arnolds en Veerkamp, 2008). Een groot deel van de voor broekbos kenmerkende soorten wordt bedreigd. Als oorzaken worden door Arnolds en Veerkamp genoemd de verdroging en het 
wegvallen van kwel, en de eutrofiering door toestroom van stikstof- en fosfaatrijk water. Een opvallende soort is het Beekmijtertje, een knotsvormig paddenstoeltje, dat groeit op rottende bladeren in bron- en kwelgebieden.

Het belang van broekbossen voor korstmossen is beperkt, omdat de stammen van de els pas op zeer hoge leeftijd begroeid raken (Stortelder et al. 1998) en berkenbomen door hun zure schors relatief arm zijn aan epifyten.

\section{Oppervlakte beekmoeras voor fauna}

Voor het natuurtype 'N14.01 Rivier- en beekbegeleidend bos' geldt dat wanneer het broekbos geïsoleerd ligt en de oppervlakte groter is dan $1.5 \mathrm{~km}^{2}$ het "goed" scoort. Voor een aantal indicatieve soorten uit moerasbossen en directe omgeving (niet compleet en niet automatisch in het Geeserstroomdal voorkomend) is een oppervlak in $\mathrm{km}^{2}$ voor de minimale omvang van het leefgebied beschikbaar (Alterra 2001):

Vlinders

Apatura iris (grote weerschijnvlinder) $\quad 0.5$

Lycaena dispar (grote vuurvlinder) $\quad 0.5$

Brenthis ino (purperstreepparelmoervlinder) $\quad 0.05$

Zoogdieren

Castor fiber (bever)

Lutra lutra (otter)

(0.06-0.09) 3

Myotis daubentonii (watervleermuis)

50-150

Neomys fodiens (waterspitsmuis)

1-10 (incl. jachtgebied)

Micromys minutus (dwergmuis)

0.05

Microtus oeconomus (noordse woelmuis) $\quad 0.5$

Vogels

Alcedo atthis (ijsvogel)

Botaurus stellaris (roerdomp)

Luscinia svecica (blauwborst)

Locustella luscinioides (snor)

0.05

Acrocephalus arundinaceus (grote karekiet) 3

Locustella naevia (sprinkhaanrietzanger) 3

Acrocephalus schoenobaenus (rietzanger) $\quad 0.55$

Amfibieen

Pelobates fuscus (knoflookpad) 0.5

Hyla arborea (boomkikker) 0.5

Triturus cristatus (kamsalamander) $\quad 0.05$

Lissotriton helveticus (vinpootsalamander) $\quad 0.05$

Mesotriton alpestris (alpenwatersalamander) $\quad 0.05$

Bufo calamita (rugstreeppad) 0.5

Rana arvalis (heikikker) 0.5

Rana lessonae (poelkikker) $\quad 0.5$

Natrix natrix (ringslang) 3

\subsection{Beheer: niets doen}

Zwarte els kiemt, zoals beheerders van natuurontwikkelingsprojecten maar al te goed weten, zeer gemakkelijk op vochtige, kale grond in het volle daglicht. In een gesloten vegetatiedek 
of onder schaduwrijke omstandigheden verloopt de kieming beduidend moeilijker. In een opgaand, gesloten broekbos worden zelden tot nooit zaailingen van els aangetroffen. Het is dan ook te verwachten dat bij de ontwikkeling van natuurlijk elzenbroekbos wortelkluiten in grote stormgaten voor de vestiging van een nieuwe generatie elzen een sleutelrol zullen spelen. Over grote oppervlakten zullen echter ook na windworp ongunstige omstandigheden voor kieming van els blijven bestaan. Het is dan ook niet te verwachten dat ongestoorde ontwikkeling van beekdallandschappen zal leiden tot aaneengesloten oppervlakten broekbos. Mozaïeken van kleine broekbossen (mogelijk met een hoger aandeel berk dan tegenwoordig), struwelen van Grauwe wilg en hoog opgaande moerasruigten vormen een waarschijnlijker toekomstbeeld. Binnen deze mozaïeken kunnen herbivoren - en met name ook bevers - een belangrijke rol spelen bij het creëren van ecologisch waardevolle overgangen tussen bos, struweel en moerasruigte (Runhaar et al. 2013). 


\section{Toekomstig beeld van de ontwikkeling van het landschap in het dal van de Geeserstroom}

\subsection{Ontwikkelingen in de vegetatietypen}

De vegetatietypen beschreven door Van der Veen (2009) en de ruimtelijke verspreiding daarvan zijn gebruikt als uitgangspunt om de mogelijke ontwikkelingen in de vegetatie in het dal van de Geeserstroom te voorspellen. Van der Veen (2009) positioneerden de zelf gedefinieerde vegetatietypen in een tweedimensionaal schema met op de $\mathrm{x}$-as voedselrijkdom en op de $y$-as vochthuishouding en waar kwel, plaggen en regenwaterinvloed aan werden toegevoegd als differentiërend (figuur 5.1).

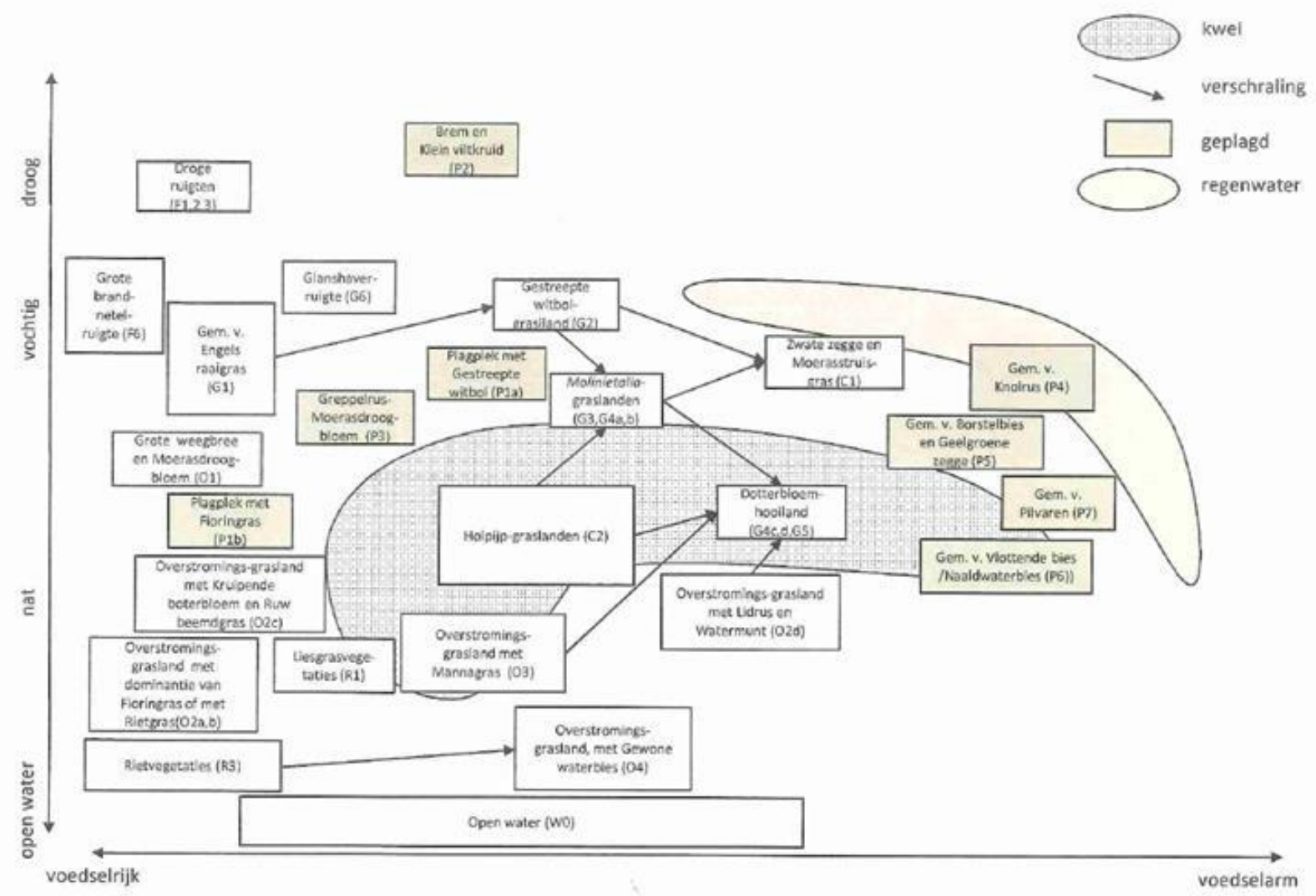

Figuur 5.1 Relatieschema diverse vegetaties Mars- en Geeserstroom (van der Veen 2009).

Het schema van Van der Veen (2009) is als basis gebruikt om de ontwikkelingen in de vegetaties te voorspellen. Er zijn door Van der Veen (2009) verschillende hoofdgroepen van vegetatietypen onderscheiden: water-/oevervegetaties, droge ruigten, moerasvegetaties, overstromingsgraslanden, graslanden, vochtige tot natte ruigten, pioniervegetaties en struwelen en bossen. Voor de meeste door Van der Veen (2009) beschreven vegetatietypen kunnen ontwikkelingsreeksen worden opgesteld. Daartoe zijn de typen eerst toegedeeld aan gemeenschappen in de vegetatie van Nederland (Schaminee et al. 1995). Deze toedeling is gebaseerd op een inschatting van aanwezige soorten en milieukenmerken en is indicatief bedoeld (tabel 5.1). 
Tabel 5.1 Koppeling van de vegetatietypen naar Van der Veen (2009), SBB en Vegetatie van Nederland.

\begin{tabular}{|c|c|}
\hline Van der Veen type (code)(SBB vegetatietype) & Vegetatie van Nederland \\
\hline \multicolumn{2}{|l|}{ Water-/oevervegetatie } \\
\hline Watervegetatie (W) & Niet verwerkt \\
\hline \multicolumn{2}{|l|}{ Droge ruigte } \\
\hline Droge ruigten $(F 1,2,3)(16-b, c, h ; 31-d)$ & Niet verwerkt \\
\hline \multicolumn{2}{|l|}{ Moerasvegetatie } \\
\hline Liesgrasvegetaties (R1)(08a) & RG Liesgras (RG Glyceria maxima [Phragmitetea]) \\
\hline Grote lisdoddevegetatie (R2)(08-f) & RG Grote lisdodde (RG Typha latifolia [Phragmitetea]) \\
\hline Rietvegetaties (R3)(08-f;32-d) & $\begin{array}{l}\text { Rietassociatie (Typho-Phragmitetum) / RG Solanum } \\
\text { dulcamara-Phragmites australis [Convolvulo- } \\
\text { Filipenduletea]) }\end{array}$ \\
\hline Grote egelskopvegetaties (R4) & $\begin{array}{l}\text { Grote egelskopassociatie (Associatie van Egelskop en } \\
\text { Pijlkruid (Sagittario-Sparganietum)) }\end{array}$ \\
\hline \multicolumn{2}{|l|}{ Kleine zeggevegetatie } \\
\hline Zwarte zegge en Moerasstruisgras (C1)(09Aa3) & $\begin{array}{l}\text { Associatie van Moerasstruisgras en Zompzegge } \\
\text { typicum (Carici curtae-Agrostietum caninae) }\end{array}$ \\
\hline Holpijp-graslanden (C2)(09-e) & $\begin{array}{l}\text { Holpijpassociatie (Equisetum fluviatile } \\
\text { [Phragmeitetalia] /[Parvocaricetea]) }\end{array}$ \\
\hline \multicolumn{2}{|l|}{ Overstromingsgrasland } \\
\hline Grote weegbree en Moerasdroogbloem (O1)(12Aa2) & $\begin{array}{l}\text { Associatie van Varkenskers en Schijfkamille } \\
\text { typicum(Coronopodo-Matricarietum typicum) }\end{array}$ \\
\hline $\begin{array}{l}\text { Overstromingsgrasland met dominantie van Fioringras } \\
\text { of met Rietgras }(\mathrm{O} 2 \mathrm{a}, \mathrm{b})(12 \mathrm{~B}-\mathrm{j} ; 12 \mathrm{~B} 1 \mathrm{~d})\end{array}$ & $\begin{array}{l}\text { RG Fioringras (RG Agrostis stolonifera [Lolio- } \\
\text { Potentillion anserinae]) / Associatie van Geknikte } \\
\text { vossestaart (Ranunculo-Alopecuretum geniculate } \\
\text { inops) }\end{array}$ \\
\hline $\begin{array}{l}\text { Overstromingsgrasland met Kruipende boterbloem en } \\
\text { Ruw beemdgras }(\mathrm{O} 2 \mathrm{c})(12 \mathrm{~B} 1 \mathrm{~d})\end{array}$ & $\begin{array}{l}\text { Associatie van Geknikte vossestaart (Ranunculo- } \\
\text { Alopecuretum geniculati inops) }\end{array}$ \\
\hline $\begin{array}{l}\text { Overstromingsgrasland met Lidrus en Watermunt } \\
(\mathrm{O} 2 \mathrm{~d})(12 \mathrm{~B} 1 \mathrm{c})\end{array}$ & $\begin{array}{l}\text { Associatie van Geknikte vossestaart (Ranunculo- } \\
\text { Alopecuretum geniculati equisetosum palustris) }\end{array}$ \\
\hline Overstromingsgrasland met Mannagras (O3)(12B-k) & $\begin{array}{l}\text { Zilverschoonverbond RG Mannagras (RG Glyceria } \\
\text { fluitans [Nasturcio-Glycerietalia]) }\end{array}$ \\
\hline $\begin{array}{l}\text { Overstromingsgrasland met Gewone waterbies } \\
(\mathrm{O} 4)(12 \mathrm{~B}-\mathrm{h})\end{array}$ & $\begin{array}{l}\text { Zilverschoonverbond RG Gewone waterbies (RG } \\
\text { Eleocharis palustris ?[Lolio-Potentillion anserinae]) / } \\
\text { Associatie van Moeraszoutgras en Fioringras } \\
\text { (Triglochino-Agrostietum stoloniferae) }\end{array}$ \\
\hline \multicolumn{2}{|l|}{ Grasland } \\
\hline $\begin{array}{l}\text { Gemeenschap van Engels raaigras en Ruw } \\
\text { beemdgras }(\mathrm{G} 1)(12 \mathrm{a} ; 16-\mathrm{m})\end{array}$ & $\begin{array}{l}\text { RG Ruw beemdgras en Engels raaigras (RG Poa } \\
\text { trivilalis-Lolium perenne [Plantaginetea } \\
\text { majoris/Cynosurion cristati]) }\end{array}$ \\
\hline $\begin{array}{l}\text { Gestreepte witbol en Engels raaigrasgrasland } \\
\text { (G2)(16l) }\end{array}$ & $\begin{array}{l}\text { RG Gestreepte witbol en Engels raaigras (RG Holcus } \\
\text { lanatus-Lolium perenne [Molinio-Arrhenatheretea]) }\end{array}$ \\
\hline Molinietalia-graslanden $(\mathrm{G} 3, \mathrm{G} 4 \mathrm{a}, \mathrm{b})(16-\mathrm{i}, \mathrm{r}, \mathrm{e})$ & $\begin{array}{l}\text { RG Gewoon struisgras en Biggekruid (RG Agrostis } \\
\text { capillaris-Hypochaeris radicata [Trifolio-Festucetalia } \\
\text { ovinae / Molinietalia]) / RG Pitrus (RG Juncus effusus } \\
\text { [Molinietalia/Lolio-Potentillion]) / ?RG Ruwe smele en } \\
\text { Geknikte vossestaart (Alopecurus geniculatus- } \\
\text { Deschampsia cespitosa [Molinietalia/Lolio-Potentillion]) }\end{array}$ \\
\hline Dotterbloemhooiland (G4c,d, G5)(16B-b;16B1a) & $\begin{array}{l}\text { [Dotterbloem- verbond (Calthion palustris)] } \\
\text { Moerasrolklaver en Echte koekoeksbloem (RG Holcus } \\
\text { lanatus-Lychnis flos-cuculi [Molineitalia]) / Associatie } \\
\text { van Boterbloem en Waterkruiskruid typicum } \\
\text { (Ranunculo-senecionetum aquatici) }\end{array}$ \\
\hline Glanshaverruigte (G6)(16C-f,kj) & Glanshaverassociatie (Arrhenatheretum elatioris) \\
\hline \multicolumn{2}{|l|}{ Vochtige tot natte ruigte } \\
\hline Grote brandnetelruigte (F6)(33-a) & $\begin{array}{l}\text { RG Brandnetelruigte (Urtica dioica-[Galio-Urticetea] / } \\
\text { RG Urtica dioica [Convolvulo-Filipenduletea]) }\end{array}$ \\
\hline Pitrusruigten (F7a-c)(16-r;09-k) & $\begin{array}{l}\text { RG Pitrus (RG Juncus effusus [Molinietalia/Lolio- } \\
\text { Potentillion]) }\end{array}$ \\
\hline Rietgrasruigten (F8)(08-b) & $\begin{array}{l}\text { RG Rietgras (RG Phalaris arundinacea } \\
\text { [Phragmitetea]) }\end{array}$ \\
\hline \multicolumn{2}{|l|}{ Pioniervegetatie } \\
\hline Plagplek met Gestreepte witbol (P1a)(16-I) & $\begin{array}{l}\text { RG Gestreepte witbol en Engels raaigras (RG Holcus } \\
\text { lanatus-Lolium perenne [Molinio-Arrhenatheretea]) }\end{array}$ \\
\hline
\end{tabular}




\begin{tabular}{|l|l|}
\hline Plagplek met Fioringras (P1b)(12B-j) & $\begin{array}{l}\text { RG Fioringras (RG Agrostis stolonifera [Lolio- } \\
\text { Potentillion anserinae]) }\end{array}$ \\
\hline Brem en Klein-viltkruid (P2)(20-c) & $\begin{array}{l}\text { RG Brem (Cytisus scoparius [Calluno- } \\
\text { Ulicetea/Nardetea]) }\end{array}$ \\
\hline Greppelrus-Moerasdroogbloem (P3)(28-a) & $\begin{array}{l}\text { RG Moersadroogbloem (RG Gnaphalium uliginosum } \\
\text { [lsoeto-Nanojuncetea/Bidentetea tripartitae]) }\end{array}$ \\
\hline Gemeenschap van Knolrus (P4)(400,O6-d) & $\begin{array}{l}\text { RG Knolrus (RG Juncus bulbosus-Sphagnum } \\
\text { [Littorello-Eleocharitetum]) }\end{array}$ \\
\hline $\begin{array}{l}\text { Gemeenschap van Borstelbies en Geelgroene zegge } \\
\text { (P5)(28A2) }\end{array}$ & $\begin{array}{l}\text { Draadgentiaan-associatie (Cicenietum filiformis } \\
\text { juncetosum [Nanocyperion flavescentis]) }\end{array}$ \\
\hline $\begin{array}{l}\text { Gemeenschap van Vlottende bies/Naaldwaterbies } \\
\text { (P6)(06C2;06D1) }\end{array}$ & Associatie van Vlottende bies (Scirpetum fluitantis) \\
\hline Gemeenschap van Pilvaren (P7)(06C1) & Pilvarenassociatie (Pilularietum globuliferae) \\
\hline Struwelen en bossen & $\begin{array}{l}\text { Associatie van Grauwe wilg (Salicetum cinereae) } \\
\text { Grauwe wilg (B1)(36A2) }\end{array}$ \\
\hline Zwarte els en Gewone es (B2)(39A-b,-d) & $\begin{array}{l}\text { RG Grote brandnetel (RG Urtica dioica [Alnion } \\
\text { [Alnion glutinosae]) }\end{array}$ \\
\hline Zomereik en Berk (B3)(42-c,42A1d) & $\begin{array}{l}\text { RG Gladde witbol en Stekelvaren (Rg Holcus- } \\
\text { Druopteris [Quercion roboris]) / Berken-Eikenbos } \\
\text { subassociatie Pijpestrootje (Betulo-Quercetum roboris } \\
\text { molinietosum) }\end{array}$ \\
\hline Zomereik en Beuk (B4)(42-e,42A2c) & $\begin{array}{l}\text { RG Braam (RG Rubus fructicosus [Alnion glutinosae]) } \\
\text { / Beuken-Eikenbos subassociatie Lelietje-van-dalen } \\
\text { (Fago-Quercetum convallarietosum) }\end{array}$ \\
\hline Eik en Vogelkers (B5)(43B-c) & $\begin{array}{l}\text { RG Grote brandnetel (RG Urtica dioica [Ulmenion } \\
\text { carpinifoliae]) }\end{array}$ \\
\hline
\end{tabular}

Vervolgens zijn op basis van de ontwikkelingsreeksen uit de landelijke milieukartering (Kalkhoven et al. 1979) en uit de 'Vegetatie van Nederland' (Schaminee et al. (1995) reeksen opgesteld (zie ook Bijlage 2). Hiermee kan een ruimtelijke schets van te verwachten ontwikkelingen op kaart worden gezet.

\subsection{Bodemtypen en grondwaterstanden in het Geeserstroomdal}

Welk bostype in welk deel van het Geeserstroomdal op termijn potentieel voor zal gaan komen hangt samen met de groeiplaats. De relevante in beekdalen voorkomende bostypen zijn daarom gekoppeld aan bodem en grondwatertrap (tabel 5.2).

De bodemkaart van het stroomgebied van de Geeserstroom geeft een duidelijk patroon in bodemtypen en grondwatertrappen weer in twee richtingen. In de lengterichting liggen vlak langs de beek van boven- naar benedenstrooms (voorverklaring grondwatertrap zie tabel 5.3):

- $\quad$ VWzt III en IIIb (Wz1) = Moerige eerdgrond (broekeerdgrond) met moerige bodemgrond op zand $(\mathrm{t}=$ gerijpte oude klei anders dan keileem of potklei op 40-120 $\mathrm{cm}$ en ten minste $20 \mathrm{~cm}$ dik)

- $\quad$ ZZg23t IIlb (Pz1) = Beekeerdgrond; lemig fijn zand ( $\mathrm{t}=$ gerijpte oude klei anders dan keileem of potklei op $40-120 \mathrm{~cm}$ en ten minste $20 \mathrm{~cm}$ dik)

- (f) $\mathrm{aVz}$ Illb (V2) = Madeveengrond op zand zonder humuspodzol beginnend ondieper dan $120 \mathrm{~cm}$ ( $f=$ plaatselijk ijzerrijk binnen $50 \mathrm{~cm}$ beginnend en minstens $10 \mathrm{~cm}$ dik)

- $\quad \mathrm{aVc}$ II (V5) = Madeveengrond op zeggeveen, rietzeggeveen of broekveen

In de dwarsrichting liggen op de flanken in het bovenstroomse deel:

- $\quad \mathrm{Hn} 23 x \mathrm{VI}(\mathrm{Hn} 5 / 6)=$ Laarpodzolgrond; lemig fijn zand $(x=$ keileem of potklei beginnend tussen 40 en $120 \mathrm{~cm}$ en ten minste $20 \mathrm{~cm}$ dik)

en in het middenstroomse deel: 
- $\quad$ pZg23I IIIb (Pz1) = beekeerdgrond; lemig fijn zand (I = plaatselijk katteklei binnen 80 $\mathrm{cm}$ beginnend en tenminste $10 \mathrm{~cm}$ dik)

- $\quad f p Z g 23 I$ III (Pz1) = beekeerdgrond; lemig fijn zand ( $f=$ plaatselijk ijzerrijk binnen 50 $\mathrm{cm}$ beginnend en minstens $10 \mathrm{~cm}$ dik; I = plaatselijk katteklei binnen $80 \mathrm{~cm}$ beginnend en tenminste $10 \mathrm{~cm}$ dik)

- Hn21 VII (Hn3/4)= Veldpodzolgrond; leemarm en zwak lemig fijn zand En in het benedenstroomse deel:

- Hn23 IV, V, VI (Hn5) = Veldpodzolgrond; lemig fijn zand

- Hn23x VI, VII (Hn6) = Veldpodzolgrond; lemig fijn zand $(x=$ keileem of potklei beginnend tussen 40 en $120 \mathrm{~cm}$ en ten minste $20 \mathrm{~cm}$ dik)

- $\quad$ pZg23I IIIb (Pz1) = beekeerdgrond; lemig fijn zand ( $=$ plaatselijk katteklei binnen 80 $\mathrm{cm}$ beginnend en tenminste $10 \mathrm{~cm}$ dik)

- $\quad f p Z g 23 I$ III $(P z 1)=$ beekeerdgrond; lemig fijn zand $(f=$ plaatselijk ijzerrijk binnen 50 $\mathrm{cm}$ beginnend en minstens $10 \mathrm{~cm}$ dik; I = plaatselijk katteklei binnen $80 \mathrm{~cm}$ beginnend en tenminste $10 \mathrm{~cm}$ dik)

Tabel 5.3 Verklaring Grondwatertrappen.

\begin{tabular}{lll}
\hline Code & GHG $(\mathrm{cm}-\mathrm{mv})$ & $\mathrm{GLG}(\mathrm{cm}-\mathrm{mv})$ \\
\hline I & - & $<50$ \\
II & - & $50-80$ \\
IIb & $25-40$ & $50-80$ \\
III & $<40$ & $80-120$ \\
IIIb & $25-40$ & $80-120$ \\
IV & $>40$ & $80-120$ \\
V & $<40$ & $>120$ \\
Vb & $25-40$ & $>120$ \\
VI & $40-80$ & $>120$ \\
VII & $80-140$ & $>120$ \\
VIII & $>140$ & $>120$ \\
\hline
\end{tabular}

\subsection{Broekbosontwikkeling in de Geeserstroom}

De aanwezige / toekomstige combinatie bodemtype, gemiddelde grondwaterstand in zomer en winter en voedselrijkdom (nabij beek en in inundatiegebied steeds hypertroof) kan worden 'vertaald' naar de potentieel natuurlijke bosvegetatie in het dal van de Geeserstroom (tabel 5.4). Hierbij wordt aangenomen dat de grondwaterstand momenteel hoger ligt t.o.v. die aangegeven op de grondwatertrappenkaart maar lager dan de huidige door de te nemen hydrologische maatregelen.

Tabel 5.4 Bodemtype, gemiddelde grondwaterstand in zomer en winter voor en na de ingreep (zie paragraaf 3.6) en te verwachten potentieel natuurlijke (broek)bosvegetatie in het dal van de Geeserstroom.

\begin{tabular}{|l|l|l|l|}
\hline Bodemtype & $\begin{array}{l}\text { Voormalige } \\
\text { Gt }\end{array}$ & $\begin{array}{l}\text { Nieuwe } \\
\text { grondwater- } \\
\text { stand }\end{array}$ & Te verwachten broekbostype \\
\hline $\begin{array}{l}\text { Moerige eerdgrond/ } \\
\text { Broekeerdgrond } \\
\text { vWzt (Wz1), fvWzt }\end{array}$ & $\begin{array}{l}\text { GHG }<40 \\
\text { GLG 80-120 }\end{array}$ & $\begin{array}{l}\text { 'brongebied' } \\
\text { GHG }<0\end{array}$ & $\begin{array}{l}\text { Elzenbroek: RG Brandnetel ( } \\
\text { overgaand in RG Braam en op } \\
\text { kwelplekken sa Zwarte bes en } \\
\text { typische vorm) }\end{array}$ \\
\hline
\end{tabular}




\begin{tabular}{|c|c|c|c|}
\hline & & $\begin{array}{l}><\text { Bollema } \\
\text { nabij loop } \\
\text { GG }<0 \\
\text { verder af van } \\
\text { loop } \\
\text { GG } 0-40\end{array}$ & $\begin{array}{l}\text { Geen broekbos en plekken } \\
\text { Wilgenstruweel: Geoorde wilg } \\
\text { Elzenborek: RG Braam }\end{array}$ \\
\hline $\begin{array}{l}\text { Beekeerdgrond met } \\
\text { lemig fijn zand } \\
(\text { (fpZg23t, pZg23(t), } \\
\text { fpZg23x) (Pz1) }\end{array}$ & $\begin{array}{l}\text { GHG }<40 \\
\text { GLG } 80-120\end{array}$ & $\begin{array}{l}\text { nabij loop } \\
\text { GHG <0 } \\
\text { GLG 0-40 } \\
\text { nabij loop } \\
\text { GG <0 } \\
\text { dalrand } \\
\text { GHG 0-40 } \\
\text { GLG 40-80 }\end{array}$ & $\begin{array}{l}\text { Elzenbroek: RG Brandnetel ( } \\
\text { overgaand in Rg Braam en op } \\
\text { kwelplekken sa Zwarte bes en } \\
\text { typische vorm) } \\
\text { Geen broekbos en plekken } \\
\text { Wilgenstruweel: Geoorde wilg } \\
\text { Elzenbroek: sa Framboos }\end{array}$ \\
\hline $\begin{array}{l}\text { Madeveengrond } \\
((\mathrm{f}) \mathrm{aVz}(\mathrm{t}))(\mathrm{V} 2)\end{array}$ & $\begin{array}{l}\text { GHG }<0 \\
\text { GLG } 50-80\end{array}$ & $\begin{array}{l}\text { nabij loop } \\
\text { GHG }<0 \\
\text { GLG 0-40 } \\
\text { nabij loop } \\
\text { GG }<0\end{array}$ & $\begin{array}{l}\text { Elzenbroek: RG Brandnetel ( } \\
\text { overgaand in Rg Braam en op } \\
\text { kwelplekken sa Zwarte bes en } \\
\text { typische vorm) } \\
\text { Geen broekbos en plekken } \\
\text { Wilgenstruweel: Geoorde wilg }\end{array}$ \\
\hline $\begin{array}{l}\text { Laarpodzol (cHn23x) } \\
(\mathrm{Hn} 5 / 6)\end{array}$ & $\begin{array}{l}\text { GHG }<40 \\
\text { GLG }>120\end{array}$ & $\begin{array}{l}\text { GHG 0-40 } \\
\text { GLG 40-80 } \\
\text { GHG 40-80 } \\
\text { GLG 80-120 } \\
\text { GHG 120- } \\
160 \\
\text { GLG >200 }\end{array}$ & $\begin{array}{l}\text { Elzenbroek: RG Hennegras (minder } \\
\text { dynamisch) en overgaand in RG } \\
\text { Framboos (meer dynamisch) } \\
\text { Berken-Zomereikenbos (vochtiger) } \\
\text { Eiken-Berkenbos (droger) } \\
\text { Beuken-Eikenbos }\end{array}$ \\
\hline $\begin{array}{l}\text { veldpodzolgronden } \\
\text { (Hn21) (Hn3/4) }\end{array}$ & $\begin{array}{l}\text { GHG 80- } \\
140 \\
\text { GLG }>120\end{array}$ & $\begin{array}{l}\text { GHG } 40-80 \\
\text { GLG }>80\end{array}$ & $\begin{array}{l}\text { Berken-Zomereikenbos (vochtiger) } \\
\text { Eiken-Berkenbos (droger) }\end{array}$ \\
\hline
\end{tabular}

Door de droogleggingskaarten met droge en natte situatie te combineren met bodemkaart wordt de potentiele broekbosvegetatie in het Geeserstroomdal zichtbaar (Figuur 5.2). 


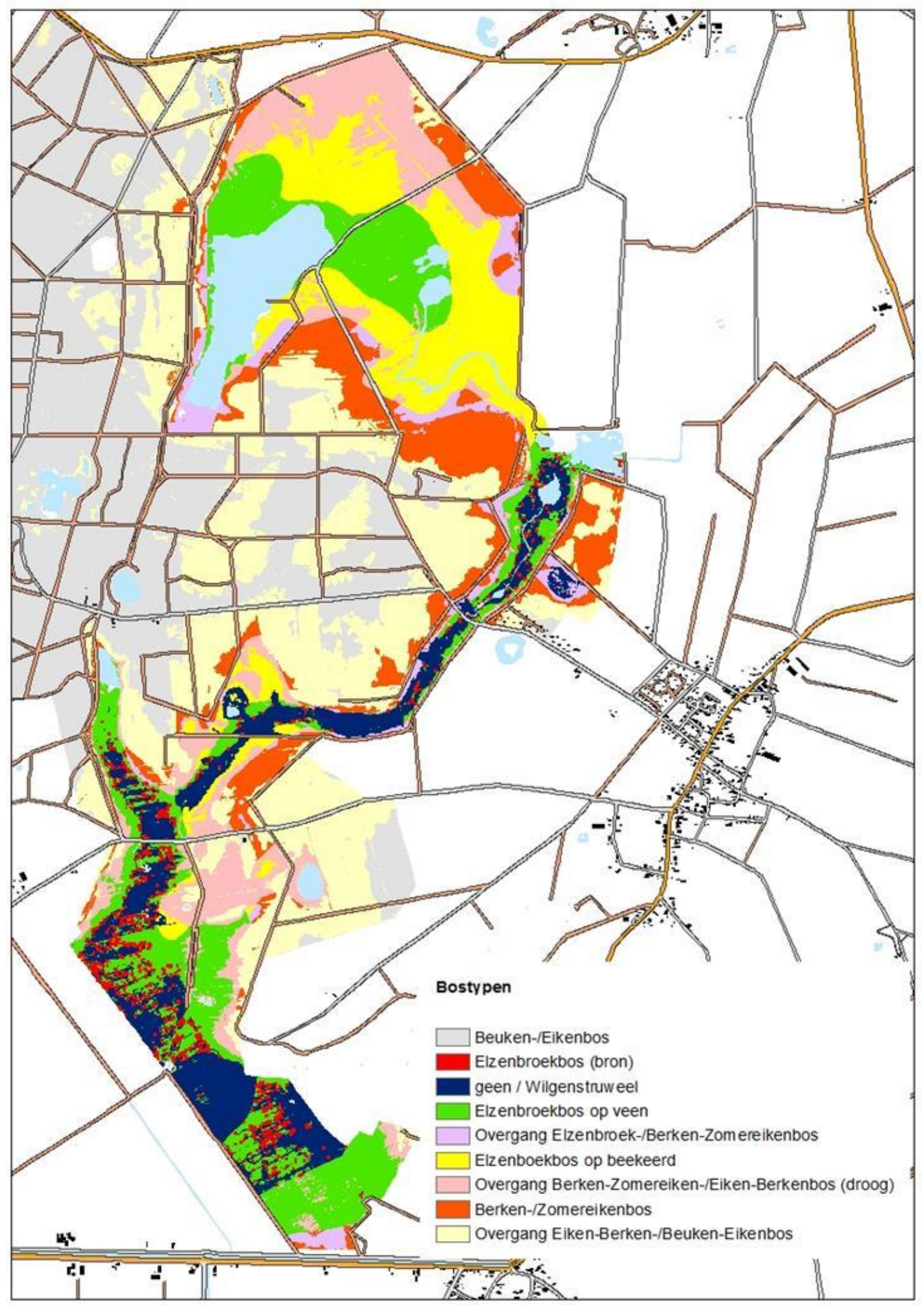

Figuur 5.2 De potentiele bostypen in het dal van de Geeserstroom na uitvoering van de in hoofdstuk 3 geduide maatregelen. 


\section{Landschappelijke en ecologische ontwikkelingen}

\subsection{Potenties voor ontwikkeling broekbossen in het Geeserstroomdal}

Een belangrijke voorwaarde voor ontwikkeling van broekbossen op voormalige landbouwgronden is het herstel van de gewenste hydrologische condities, met hoge grondwaterstanden in winter en voorjaar en aanvoer van grondwater gedurende tenminste een belangrijk deel van het jaar. Herstel van de hydrologie is het meest kansrijk wanneer een forse kweldruk, waarbij de stijghoogte in de ondergrond tot aan of boven maaiveld staat, aanwezig/hersteld is. Indien de stijghoogte in de ondergrond nabij of onder het maaiveld staat, leidt de noodzakelijke vernatting tot infiltratie van regenwater en daarmee tot verzuring.

Het is belangrijk dat vernatting niet te sterk wordt doorgevoerd omdat dan interne eutrofiering op kan treden. Door de opstuwing in de Geeserstroom is dat momenteel wel aan de orde. Ontwikkeling van Elzen onder relatief te droge omstandigheden kan echter ook tot problemen leiden indien later de waterstanden verhoogd worden. Dit is in het Geeserstroomdal niet aan de orde.

Het is de vraag of het enkel nemen van (de juiste) hydrologische ingrepen toereikend is voor het herstel van Elzenbroekbossen op voormalige landbouwgronden. Deze zijn immers jarenlang bemest waardoor de toplaag van de bodem doorgaans rijker zal zijn aan nutriënten (zowel $\mathrm{N}$ als $\mathrm{P}$ ) dan (verdroogde) Elzenbroekbossen. Verder is in natte broekbossen ammonium de dominante stikstof vorm, terwijl dit op droge landbouwgrond meestal nitraat is, en is de ammonium concentratie in broekbossen meestal vergelijkbaar met die in landbouwgronden. De relatief lagere nitraatconcentraties in broekbossen worden veroorzaakt door de geringere nitrificatie en snellere denitrificatie in deze natte systemen.

De rol van kiemingsomstandigheden, in combinatie met de zaadbeschikbaarheid in de eerste fase na genomen herstelmaatregelen, kan de ontwikkeling van Elzenbroekbos blokkeren. Hoge gehalten aan $\mathrm{P}$ in de bodem en ook begrazing hebben in het Geeserstroomdal de ontwikkeling van typische bosvegetaties beïnvloed en belemmerd.

Het is niet bekend hoe (de ondergroei van) Elzenbroek zich kwalitatief zal ontwikkelen bij verschillende nutriëntengehalten in de bodem (van mesotroof tot uiterst eutroof). Het is echter aannemelijk dat soorten als Liesgras en Pitrus eenzelfde uitwerking zullen hebben indien de nutriëntenbeschikbaarheid hoog is. Observaties in het veld laten zien dat beoogde ontwikkeling van Elzenbos op rijke landbouwgrond in o.a. het Beekbergerwoud sterk word gefrustreerd door de ontwikkeling van een zeer ruige soortenarme ondergroei. Zo is het goed denkbaar dat de massale groei van Pitrus op voormalige landbouwgrond de beoogde ontwikkeling van Elzen en de karakteristieke soorten in de ondergroei zal belemmeren.

In Polen is onderzoek naar de kolonisatiesnelheid van typische soorten uit de ondergroei van elzenbroekbossen verricht in nieuwe elzenbroekbossen op landbouwgrond grenzend aan bestaande oude broekbossen (Orczewska, 2009). Hieruit kwam naar voren dat de gemiddelde migratiesnelheid van de soorten ligt tussen de 1,2 en 1,6 m per jaar. Sommige soorten bereikte echter snelheden van meer dan $4 \mathrm{~m}$ per jaar terwijl er ook soorten waren die zeer langzaam of niet koloniseerden. Verder bleek de vegetatiesamenstelling in belangrijke mate samen te hangen met de leeftijd van de nieuwe bossen en de bedekking met brandnetel (Urtica dioica). Ook uit vele andere studies blijkt dat een excessieve groei 
van brandnetel de vestiging en uitbreiding van doelsoorten sterk kan beperken. De groei van brandnetel wordt behalve door de voedselrijkdom van de bodem, ook gestimuleerd door hoge lichtniveaus en relatieve droge omstandigheden. Het is bekend dat open plekken in een bos kunnen leiden tot een versnelde mineralisatie en verhoogde beschikbaarheid van stikstof voor planten (Prescott 2002). Vooral het microklimaat (temperatuur en vochtigheid) in een bos, alsmede de veranderingen van de strooiselkwaliteit en verminderde opname van nutriënten door bomen en micro-organismen lijken hierbij bepalend te zijn. Dit betekent, omgekeerd redenerend, ook dat de ontwikkeling van een bos op termijn kan leiden tot een afname van de fertiliteit van een landbouwbodem.

De kansen op succesvol herstel zullen waarschijnlijk sterk toenemen wanneer de landbouwgronden worden verschraald (Runhaar et al. 2013). Verschralen van voormalige landbouwgronden kan snel bereikt worden door de met nutriënten verrijkte bodem te verwijderen (Smolders et al. 2008). Een bijkomend voordeel kan zijn dat het grondwater dichter bij het maaiveld komt en lokale hydrologische ingrepen eerder voldoen.

Het toedienen van zaaddozen van els, van elzenbroekbosstrooisel of aanplanten van Els, na uitvoering van een verschraling of / en plaggen, kan verder bijdragen tot een positieve ontwikkeling van broekbossen met een diverse ondergroei. Ook kan de aanvoer van bosstrooisel uit een goed ontwikkeld Elzenbroekbos bijdragen aan de introductie van de gewenste bodemfauna en bodemflora (schimmels). Zo blijkt Frankia vrijwel altijd vrijlevend voor te komen in bodems met geïnfecteerde boomsoorten (Valdez 2008). Verder is aangetoond dat introductie van Alnus-strooisel (1\% in gemalen vorm door de bodem gemengd) leidt tot een forse toename van de stikstofbinding en groei van Zwarte Els ten opzichte van elzen die op minerale bodems groeiden (Nickel et al. 2001). Bomen beïnvloeden doorgaans de ondergroei door verandering van het licht regime en de productie van strooisel met een bepaalde chemische kwaliteit. Strooiselproductie door Alnus spp., Quercus spp. en Fagus spp. verzuurt de bodem. Echter, strooisel van Alnus spp. is beter afbreekbaar dan dat van Quercus en Fagus spp. (Dossche 1998) en werkt niet verzurend. Er zijn indicaties dat het kiemings- en vestigingssucces van kruiden op verzuringgevoelige bodem sterk onder invloed staat van de kwaliteit van de strooisel en dus de boomsoort. Uit experimenten is gebleken dat kieming van ruigtesoorten verhoudingsgewijs meer optreedt in strooisel van de Populus $x$ euramericana in vergelijking met strooisel van andere boomsoorten (Alnus glutinosa, Acer pseudoplatanus en Fagus sylvatica (Thomaes et al. 2011). Samen met de grotere lichtdoorval is dit waarschijnlijk de belangrijkste oorzaak voor de meestal veel ruigere ondergroei in populierenbossen vergeleken met elzen- en eikenbossen op vergelijkbare standplaatsen.

Ongunstige kiemingsomstandigheden in de eerste fase na uitvoer van een aanvullende herstelmaatregel kan de ontwikkeling van (relatief goed ontwikkeld) elzenbroekbos dus blokkeren. De primaire vestiging van soorten zal uiteindelijk een belangrijke invloed hebben op de vegetatieontwikkeling. Bovenstrooms groeiende Elzen kunnen theoretisch ook als donor fungeren voor zaad- en plantmateriaal dat bij hoog water kan worden afgezet. Introductie van zaad of aanplant zal echter het ontwikkelingsproces sterk versnellen. Ook introductie van doelsoorten kan het herstel van broekbosvegetaties verder bespoedigen. Echter, herintroductie is echter alleen dan duurzaam als het milieu geschikt is (o.a. niet te Prijk) (Baeten et al. 2009; Gilbert et al. 2003) omdat dit uiteindelijk bepalend is voor de kieming en overleving van kiemplanten (Verheyen et al. 2003).

Een mogelijk knelpunt is de voedselrijkdom van het inlaatwater bij Bollema en het grondwater. Het grondwater is sinds enkele decennia sterk verrijkt met nitraat en sulfaat. Het 
nitraat is afkomstig uit de landbouw. Hoge nitraat concentraties in het grondwater zorgen ervoor dat ijzer niet kan oplossen. Verder kan nitraat in de ondergrond ook ijzer-sulfiden uit anaerobe pyriethoudende bodemlagen oxideren waarbij sulfaat vrijkomt. Onder natte condities kan sulfaat als alternatieve electronenacceptor optreden bij de afbraak van organisch materiaal. Het sulfide dat hierbij gevormd wordt bindt sterk aan vrij ijzer en ijzer afkomstig van ijzer-fosfaatverbindingen. Hierbij komt fosfaat versneld vrij in de bodem. De concentratie ijzergebonden fosfaat is doorgaans hoog op bemeste landbouwgronden, zeker wanneer het gaat om bodems die voorheen door (ijzerhoudend) grondwater gevoed zijn. Door toenemende sulfaatreductie zal (een groot deel van) het geaccumuleerde fosfaat vrijkomen in het porievocht en de waterlaag en leiden tot verruiging (Smolders et al. 2010). Ook kunnen er bij lage ijzergehalten in de bodem, hoge concentraties sulfide ontstaan in het bodemvocht waardoor gevoelige soorten ten prooi vallen aan sulfide toxiciteit.

Voor systemen met een hoge sulfaatbelasting blijkt het van belang te zijn dat er voldoende doorstroming van het systeem plaatsvindt waardoor nutriënten worden afgevoerd. Het gevaar van stagnerend sulfaat rijk grondwater geldt niet enkel voor voormalige landbouwgronden maar zeker ook voor de omringende nog intacte kwelkernen waar vaak nog mooie kwelvegetaties aanwezig zijn. De veranderde grondwaterkwaliteit stelt dus mogelijk ook hydrologische eisen aan het systeem. Het voedselrijke inlaatwater in combinatie met een sterke uitspoeling van nutriënten uit de geïnundeerde gebiedsdelen zal voorlopig zorgen voor voedselrijke omstandigheden in de geïnundeerde gebiedsdelen. De te ontwikkelen voedselrijke broekbostypen zijn minder divers maar kunnen wellicht voor meer algemene fauna soorten toch interessant zijn.

\subsection{Scenario's in landschapsontwikkelingen}

De systeemrandvoorwaarden in het dal van de Geeserstroom in combinatie met de wens om het onderhoud te minimaliseren en een zichzelf regulerend natuurlijk beekdalsysteem te ontwikkelen hebben in zowel de beek en het dal laten zien dat zich een nieuw landschap ontwikkelt dat afwijkt van het streefbeeld maar dat tegelijk veel waarden bevat. Tegelijk zijn er knelpunten ontstaan. Om passend in de nieuwe systeemontwikkeling de knelpunten op te lossen en het nieuwe landschap zoveel mogelijk kansen te geven zijn enkele deelscenario's opgesteld. Bij de deelscenario's is uitgegaan van een situatie waarbij de knik in het verhang is verwijderd ende doorstroming vanaf Bollema is verbeterd. Deelscenario's omdat combinatie van delen in de uiteindelijke invulling mogelijk zijn.

\section{Mepper Hooilanden}

Voor de Mepper Hooilanden zijn 3 scenario's mogelijk:

Deelscenario 1: Niets doen.

De aan de grote plas gebonden vogels blijven aanwezig. Het nadeel is dat in de bestaande, te diepe plas de verlanding slechts traag op gang komt en de kwel uit de boswachterij deels wordt weggedrukt. De waterkwaliteit zal niet of nauwelijks verbeteren.

Deelscenario 2: Ondiepe plas.

Het peil door het weghalen van de drempel laten dalen (zie intermezzo), al dan niet in stappen, naar een diepte van 20-40 cm waardoor er, al dan niet geleidelijk, een kwel ontvangende plas ontstaat. Door de kwel en de invloed van regenwater zal de waterkwaliteit verbeteren. Indien het terugstromen van water vanaf gemaal Bollema 
achterblijft zal dit de waterkwaliteit extra ten goede komen. Daarvoor moet het water vanaf Bollema beter naar benedenstrooms kunnen afstromen. In de ondiepe plas kan verlanding op gang komen en de waterkwaliteit nog verder verbeteren. De vogelsamenstelling zal veranderen.

Deelscenario 3: Compartimenteren.

De plas blijft zoals die nu is maar er worden in de plas eilandjes aangelegd die al dan niet verbonden zijn met de oever. Hierdoor wordt de windwerking in de plas beperkt en neemt de oeverlengte sterk toe. Dit laatste leidt ertoe dat de verlanding enigszins versneld wordt. De eilandjes worden bij voorkeur gebouwd met bodemmateriaal uit de directe omgeving, zoals het bodemmateriaal wat bij de aanleg is opgeslagen in de boswachterij. Het nadeel zijn de kosten en verstoring van de aanleg. De vogelpopulaties zullen licht verschuiven.

In de deelscenario's 2-3 treedt een versnelde verlanding op die aansluit bij het uiteindelijke doel om dit gebied als diffuus afvoerende laagte het oorspronggebied van de Geeserstroom te laten zijn. Deelscenario 2 wordt aanbevolen.

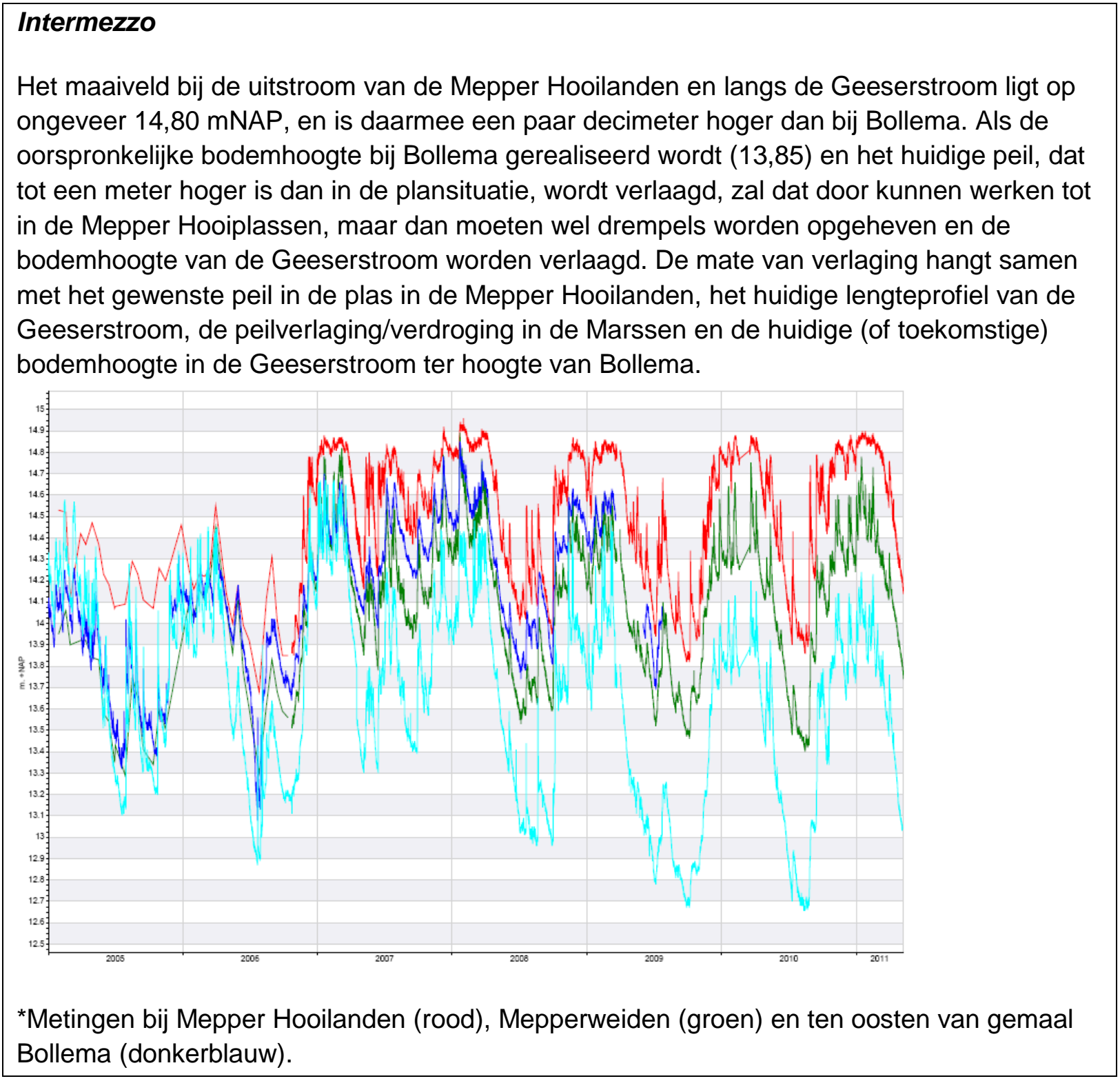




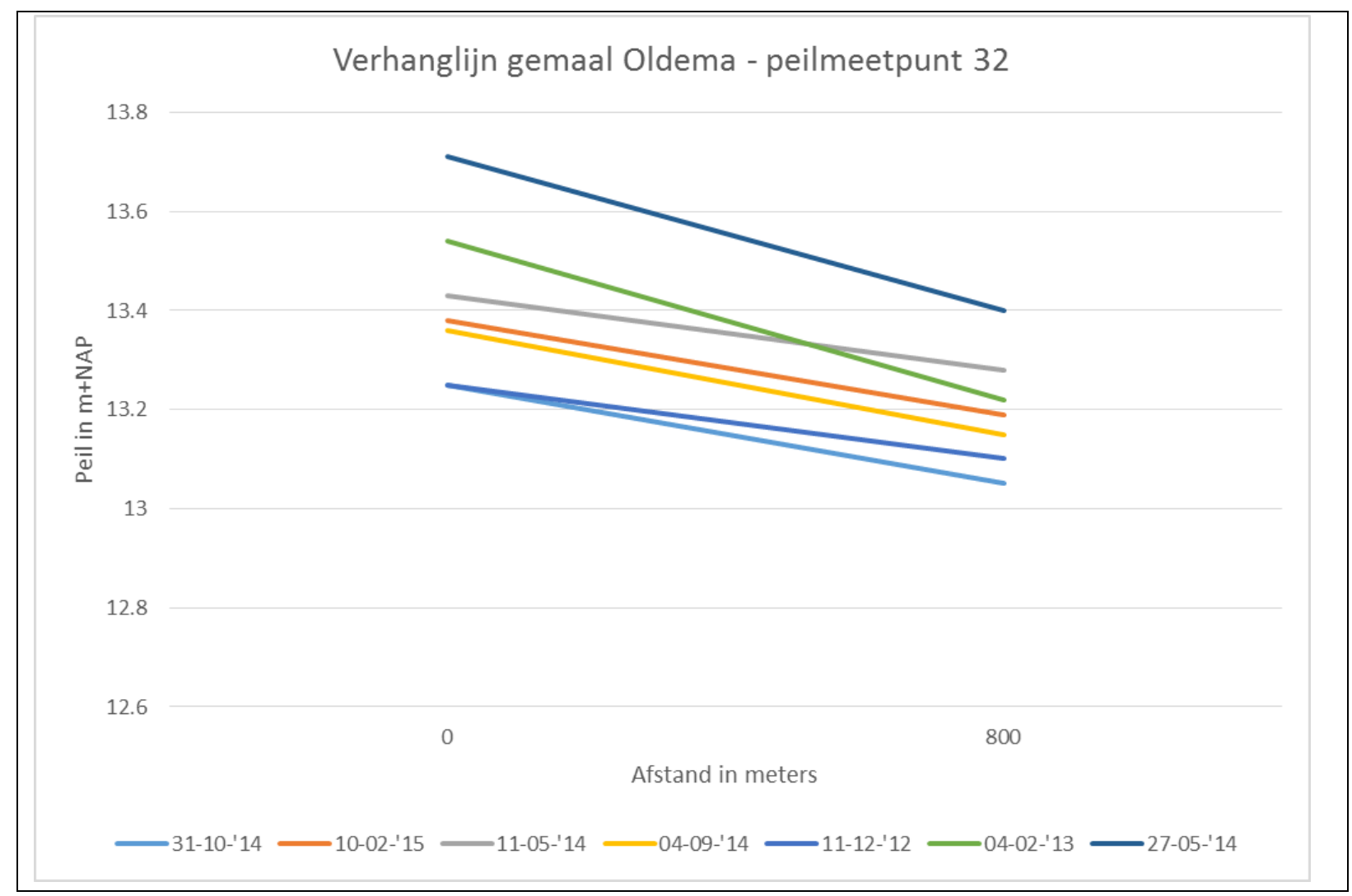

\section{Koemarserdijk - Bollema}

Deelscenario 1: Niets doen.

Het huidige pitrusmoeras ontwikkelt door in de richting van een ruigtemoeras. Het nadeel is dat de gesloten zode van het huidige pitrusmoeras maakt dat er voorlopig weinig bomen op zullen slaan. Afhankelijk van de voeding vanaf de Mepper Hooilanden, Koemarsen en Marsen zal de beginnende beekloop water voeren. Waarschijnlijk vindt regelmatig droogval plaats of ontstaat een diffuus afvoerend systeem in het verlengde van de Mepper hooiplas.

Deelscenario 2: Ruigte met beperkt beekoever begeleidende broekbos.

Door de oorspronkelijk slenk te verbreden door plaggen en met elzenzaden in te zaaien of elzenbroekstrooisel aan te brengen wordt een beekbegeleidende elzenbroek geïnitieerd. Hierdoor ontstaat een diffuus afvoerende laagte met in natte perioden een bovenloopje dat koel blijft en gaat functioneren als een natuurlijke beekbovenloop. Het nadeel is dat geplagd en gezaaid moet worden, al is dit slechts een eenmalige ingreep.

Deelscenario 3: Beekdalbreed begeleidende broekbos.

Door het huidige natte pitrusmoeras geheel te plaggen en met elzen in te zaaien (zaad of strooisel) of te planten wordt een groot broekbos geïnitieerd. Hierdoor ontstaat een diffuus afvoerende laagte met in natte perioden een bovenloopje dat koel blijft en gaat functioneren als een natuurlijke beekbovenloop in een natuurlijk beekdalbroekbos. Het nadeel is dat over een grote breedte geplagd en gezaaid of geplant moet worden, al is dit slechts een eenmalige ingreep.

Deelscenario 3 sluit het beste aan bij de nieuwe ontwikkelingen in het gebied. 


\section{Gemaal Bollema}

Door de inmiddels uitgevoerde opschoning van de geul is het de vraag of daarmee de wateroverlast in het agrarisch gebied niet al is opgelost en het peil in de plas na het gemaal is gezakt? De deelscenario's gaan in op de situatie na hydrologisch herstel.

Deelscenario 1: Overtollig water afleiden.

Eventueel verhogingen van het peil boven de oorspronkelijk geplande 14.45 m+NAP die optreden in de plas na het gemaal kunnen op twee manieren worden afgeleid. Ten eerste via een aan te leggen en te onderhouden groene by-pass die parallel loopt langs het fiets/voetpad waarbij onderhoud van de groene ader mogelijk blijft. Nadeel is dat de groene by-pass en de omleiding beheer en onderhoud behoeven en geen natuurlijke oplossing voor het probleem zijn.

Deelscenario 2: Ruigtemoeras.

Een ruigtemoeras na het gemaal kan functioneren als zuiveringsfilter. Het omvormen van de plas naar een ruigtemoeras kan de zuiverende werking versterken. Echter nadeel is dat de plas verdwijnt en bij een te groot wateraanbod een alternatieve berging gevonden moet worden. Dit kan in combinatie met deelscenario 1 of bij een voldoende afvoer van water richting Roonboom.

Deelscenario 3: Combinatie ruigtemoeras en broekbos.

Deze combinatie na het gemaal kan eveneens functioneren als zuiveringsfilter. Het omvormen van de plas naar een ruigtemoeras-broekbos kan de zuiverende werking versterken. Echter nadeel is dat de plas verdwijnt en bij een te groot wateraanbod een alternatieve berging gevonden moet worden. Dit kan in combinatie met deelscenario 1 of bij een voldoende afvoer van water richting Roonboom.

Wanneer een van bovenstaande deelscenario's toch nodig mochten blijken dan past deelscenario 3 het beste bij de nieuwe ontwikkelingen in het gebied. Dit scenario past in een beekmoeras ontwikkeling waarbij de natte ruigte met berging en nutriëntenfiltering het beekmoeras versterkt omdat water schoner en meer geleidelijk gaat afstromen richting benedenstrooms.

\section{Bollema - Tilweg en Tilweg - Goringdijk}

De knik in het bodemverhang in dit traject wordt in ieder geval weggehaald en dichtgegroeide beektrajecten worden ongeacht het scenario geschoond. De deelscenario's gaan in op het vervolg.

Deelscenario 1: Beperkt beekoever begeleidende broekbos

Door de oorspronkelijke beekloop te verbreden door plaggen en met elzenzaden in te zaaien of elzenbroekstrooisel aan te brengen wordt een beekbegeleidende elzenbroek geïnitieerd of als alternatief het aanplanten van elzen. Hierdoor ontstaat een doorstroommoeras (elzenbroekbos) wat koel blijt en gaat functioneren als een natuurlijke beekbovenloop met begeleidend moeras. Het nadeel is dat geplagd en gezaaid moet worden, al is dit slechts een eenmalige ingreep. De in de dwarsrichting vochtige tot drogere zone wordt in beheer genomen zodat een meer open cultuurlandschap (een ruigte) kan ontstaan. Het nadeel is dat de zone smal en nat is en dat het jaarlijks terugkerend beheer lastig en kostbaar wordt.

Deelscenario 3: Beekdalbreed begeleidend broekbos Door de oorspronkelijke beekloop sterk te verbreden door plaggen en met elzenzaden in te zaaien of elzenbroekstrooisel aan te brengen over bijna de gehele huidige breedte van het natuurgebied wordt een natuurlijk beekbegeleidende elzenbroek geïnitieerd. Hierdoor ontstaat een doorstroommoeras (elzenbroekbos) wat 
koel blijft en gaat functioneren als een natuurlijke beekdal bovenloop met begeleidend moeras. Het nadeel is dat over een grote breedte geplagd en gezaaid moet worden, al is dit slechts een eenmalige ingreep. Er is geen extra beheer nadien nodig.

Deelscenario 3 sluit het beste aan bij de nieuwe ontwikkelingen in het gebied omdat het op termijn resulteert in een beekdalbreed beekmoeras.

\section{Goringdijk - Verlengde Hoogeveense vaart}

Deelscenario 1: Moerasruigte.

Het gebied Klinkenberg en de berging Roonboom worden als moerasruigte ontwikkeld. Door de (grond)waterstanden voldoende lang en vaak hoog te houden kan geen bosontwikkeling optreden en ontwikkeld een moerasruigte met plaatselijk mogelijk permanente plassen. Momenteel bestaat deze situatie al en wanneer de berging Roonboom meer water krijgt als gevolg van de maatregelen bovenstrooms wordt de moerasruigte gehandhaafd (zie ook intermezzo). Los van het feit of dit landschappelijk waardevol wordt gevonden en of er dan verlies aan bergingsruimte (a.g.v. snellere toestroom van water bij uitvoering scenario's bovenstroomse delen) is, hoeven hier bij een moerasruigte geen ingrepen en aansluitend beheer plaats te vinden.

Deelscenario 3: Moerasbos en moerasruigte. In dit scenario wordt het gebied Klinkenberg en Roonboom ontwikkeld als beekdalbreed begeleidend broekbos. Door in dit traject de oorspronkelijke beekloop sterk te verbreden door plaggen en met elzenzaden in te zaaien of elzenbroekstrooisel aan te brengen over bijna de gehele huidige breedte van het natuurgebied wordt een natuurlijk beekbegeleidende elzenbroek geïnitieerd. Hierdoor ontstaat een doorstroommoeras (elzenbroekbos) wat koel blijft en gaat functioneren als een natuurlijke beekdal bovenloop met begeleidend moeras. Het nadeel is dat over een grote breedte geplagd en gezaaid moet worden, al is dit slechts een eenmalige ingreep. Er is geen extra beheer nadien nodig.

Deelscenario 3 sluit het beste aan bij de nieuwe ontwikkelingen in het gebied moerasbos en -ruigte passen binnen een gedachte van bouwen met natuur en het achterwege laten van beheer.

\section{Intermezzo}

Het hoogste peil dat in bergingsgebied Roonboom kan optreden is 13,50 mNAP. Op de kaart inundeert dan het lichtblauwe en lichtgroene gebied. Tot aan Gees staan dan percelen dan tot $30 \mathrm{~cm}$ onder water. Tot nu toe is Roonboom nog nooit op natuurlijke wijze tot het hoogste peil gevuld geweest. In de toekomst kan het gebied vaker als bergingsgebied nodig zijn en het dal van de zijbeek naar Gees incidenteel inunderen, maar dat past bij het beoogde beekdalbeeld. 


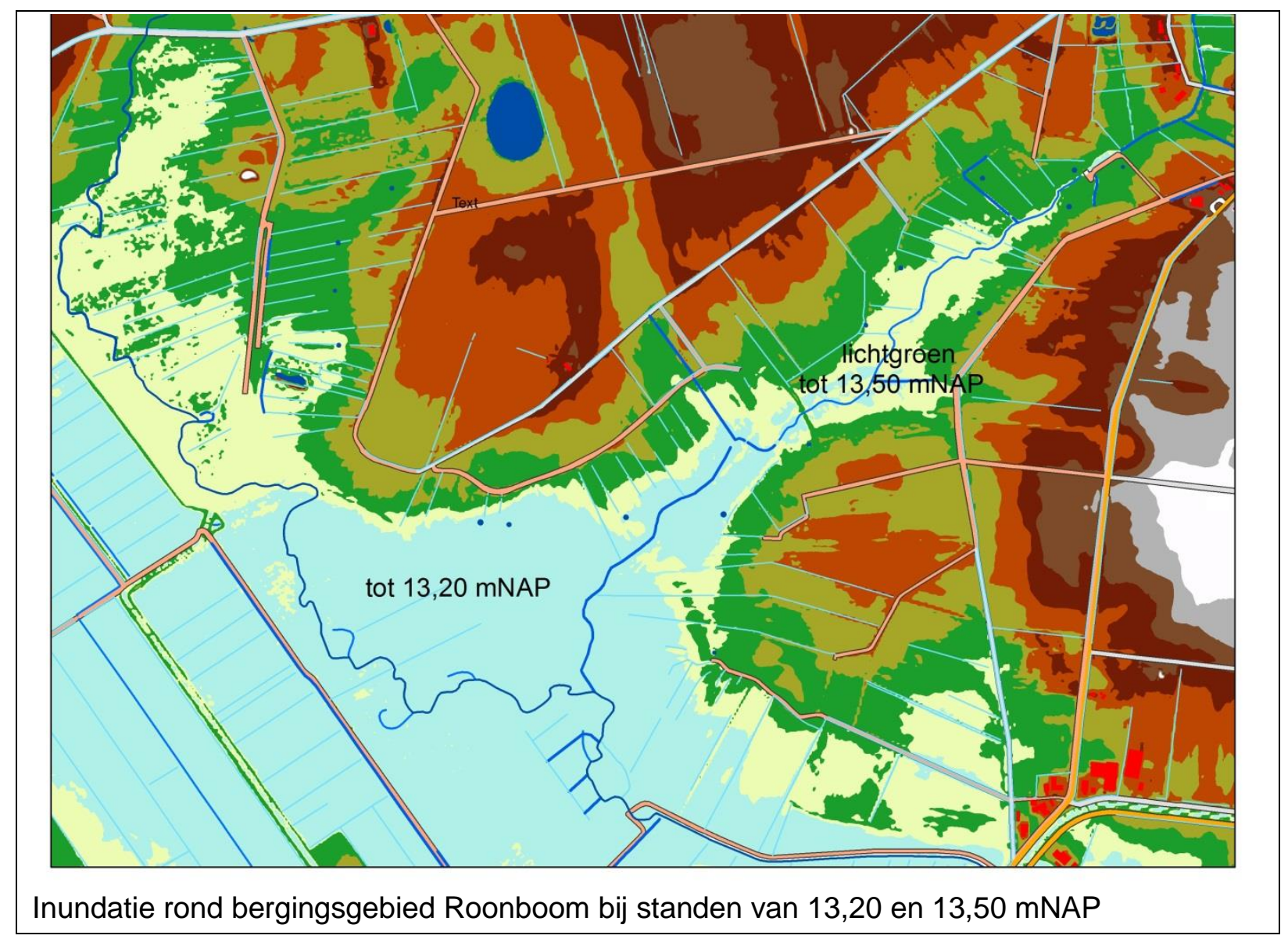

\section{Zijloop vanaf Gees}

Deelscenario 1: Moerasruigte.

Het dal van het loopje wordt als moerasruigte ontwikkeld. Door de (grond)waterstanden voldoende lang en vaak hoog te houden kan geen bosontwikkeling optreden en ontwikkeld zich een moerasruigte. Momenteel bestaat deze situatie al.

Deelscenario 2: Beperkt beekoever begeleidende houtwal.

Het dal van het loopje wordt als oud cultuurlandschap hersteld/ontwikkeld. Door de (grond)waterstanden voldoende lang en vaak hoog te houden kan geen bosontwikkeling optreden en ontwikkelt een moerasruigte of een nat schraalland dat regelmatig door rupsmaaiers gemaaid wordt. Momenteel bestaat deze situatie gedeeltelijk. Echter langs het loopje zelf wordt bovendien met een $5 \mathrm{~m}$ brede houtwal aangeplant (elzen) waardoor het beekelement beter zichtbaar wordt in het landschap en de beek schaduw en verkoeling krijgt. Omdat deze zijloop vlak bij het dorp Gees ligt zal het $19^{\text {de }}$-eeuws landschap aansluiten bij het huidige belevingsbeeld (nabij dorp Gees, hoge belevingswaarde lokale bevolking). Het nadeel is dat het zowel aanleg en beheer nadien vraagt.

Deelscenario 3: Beekdalbreed begeleidend broekbos.

Het beekdal in dit traject is relatief smal maar kan over de beschikbare breedte omgevormd worden naar beekdalbegeleidend broekbos. Door in dit traject het dal naast het loopje te plaggen en met elzenzaden in te zaaien of elzenbroekstrooisel 
aan te brengen wordt een natuurlijk beekbegeleidende elzenbroek geïnitieerd. Hierdoor ontstaat een doorstroommoeras (elzenbroekbos) wat koel blijt en gaat functioneren als een natuurlijke beekdal bovenloopje met begeleidend moeras. Het nadeel is dat over de volle breedte van het dal geplagd en gezaaid moet worden, al is dit slechts een eenmalige ingreep. Er is nadien geen extra beheer nodig.

Deelscenario 2 sluit het beste aan bij de nieuwe ontwikkelingen in het gebied omdat het deels tegemoet komt aan de wensen van bewoners voor een meer op een $19^{\text {de }}$-eeuwse uitziend landschap terwijl tegelijk de beek met hout begeleid wordt wat past in een verbost beekdal en bij het functioneren van een beek.

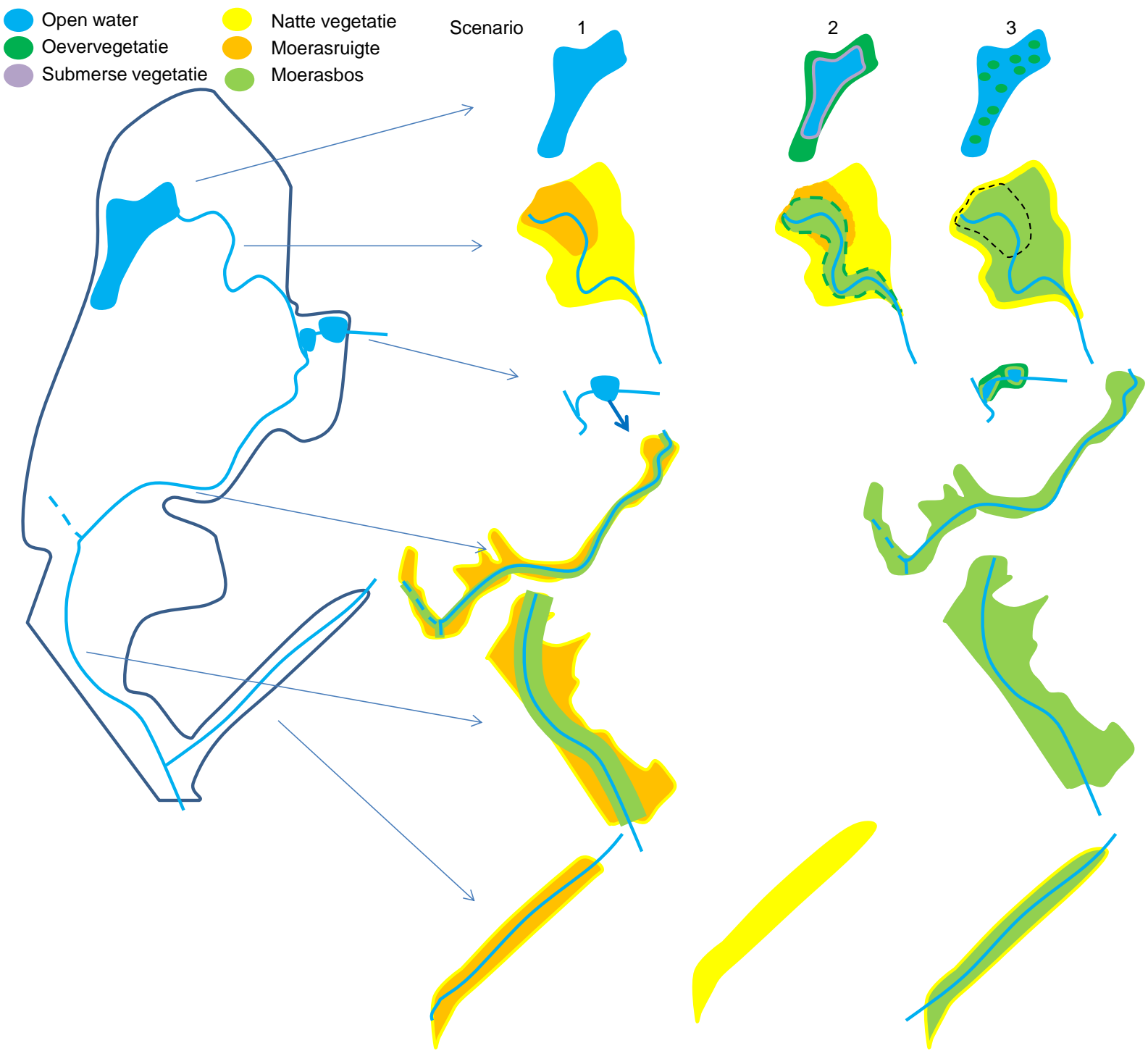

Figuur 6.1 De verschillende scenario's in schets. 


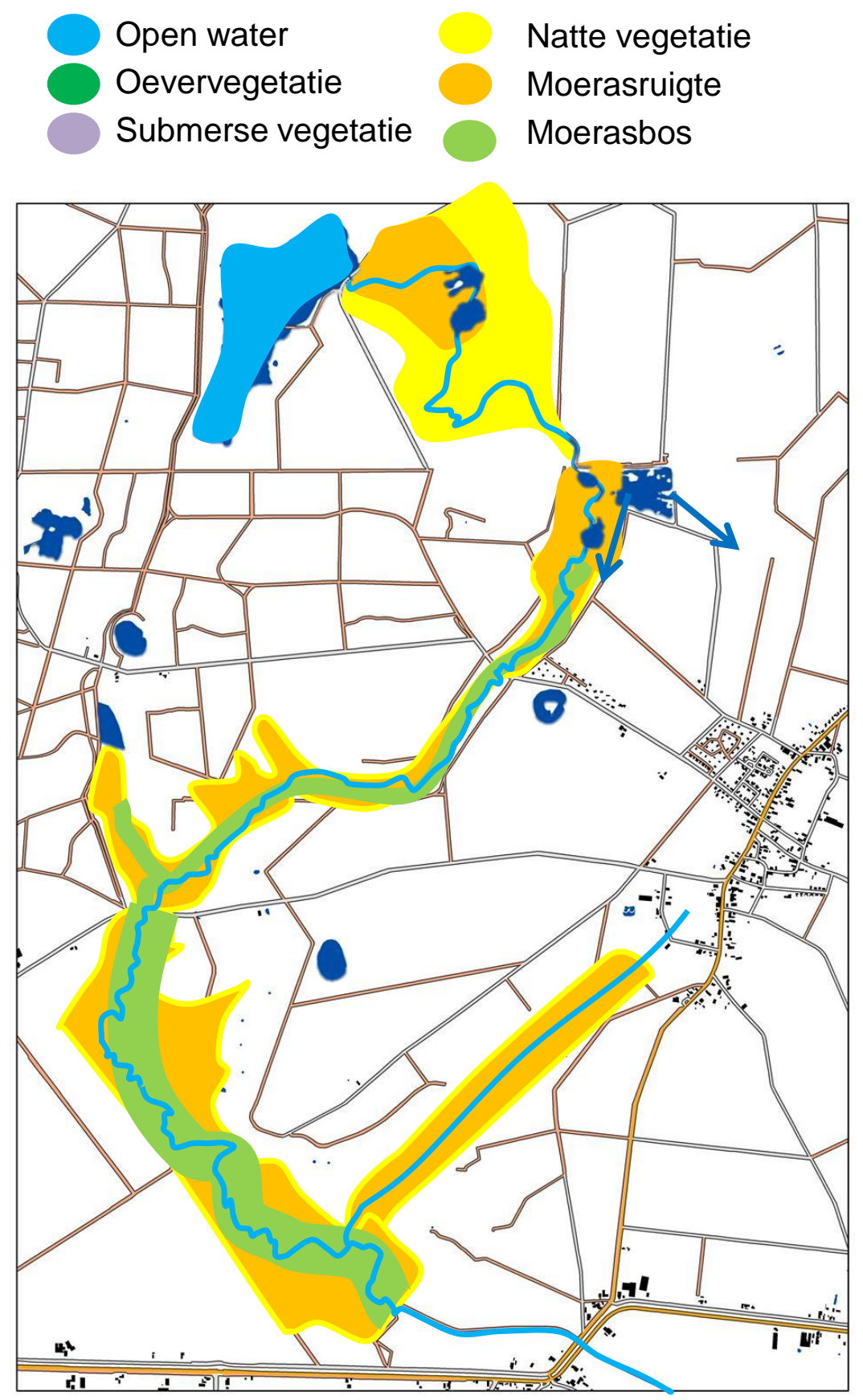

Figuur 6.2 Scenario 1. 


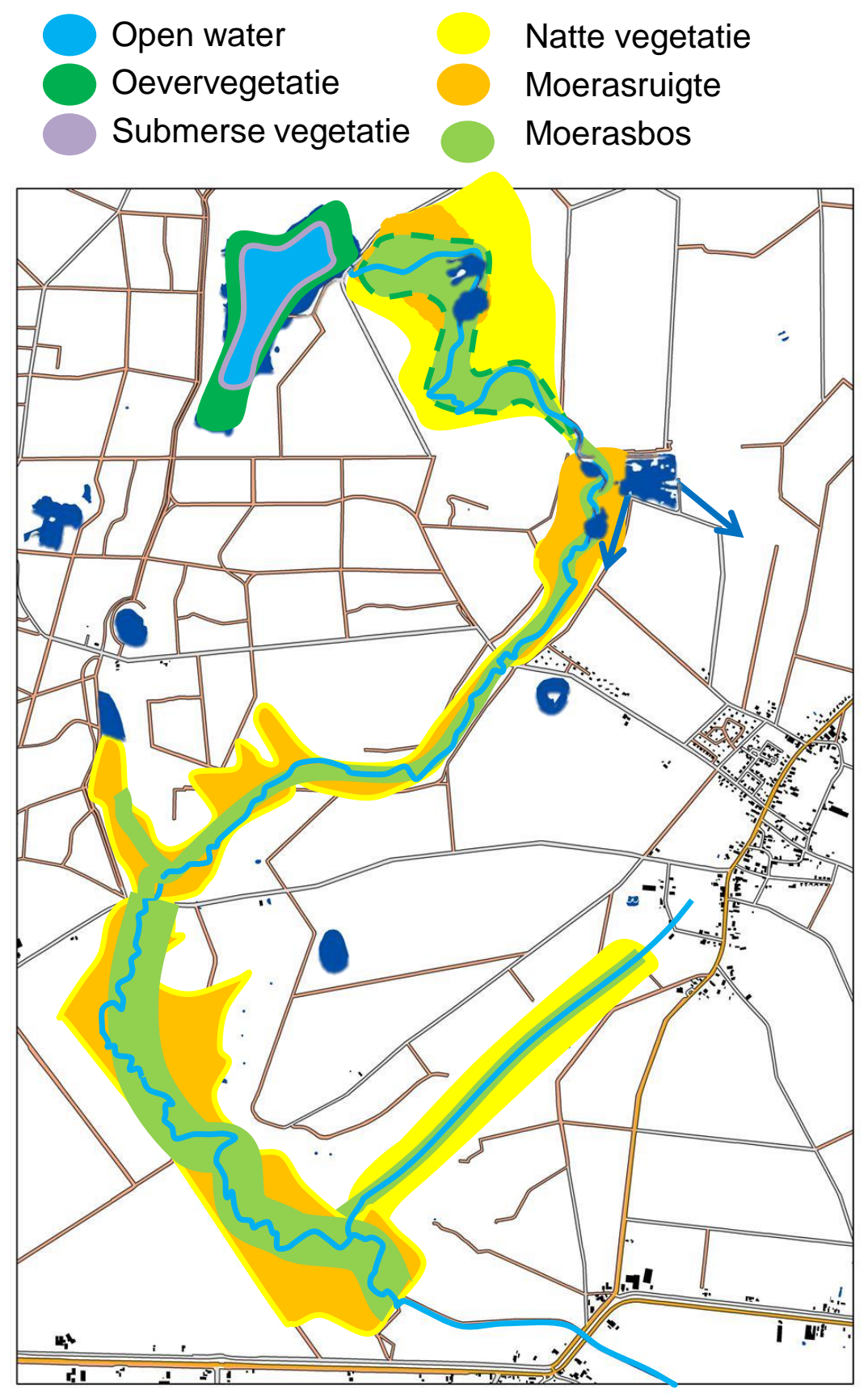

Figuur 6.3 Scenario 2. 


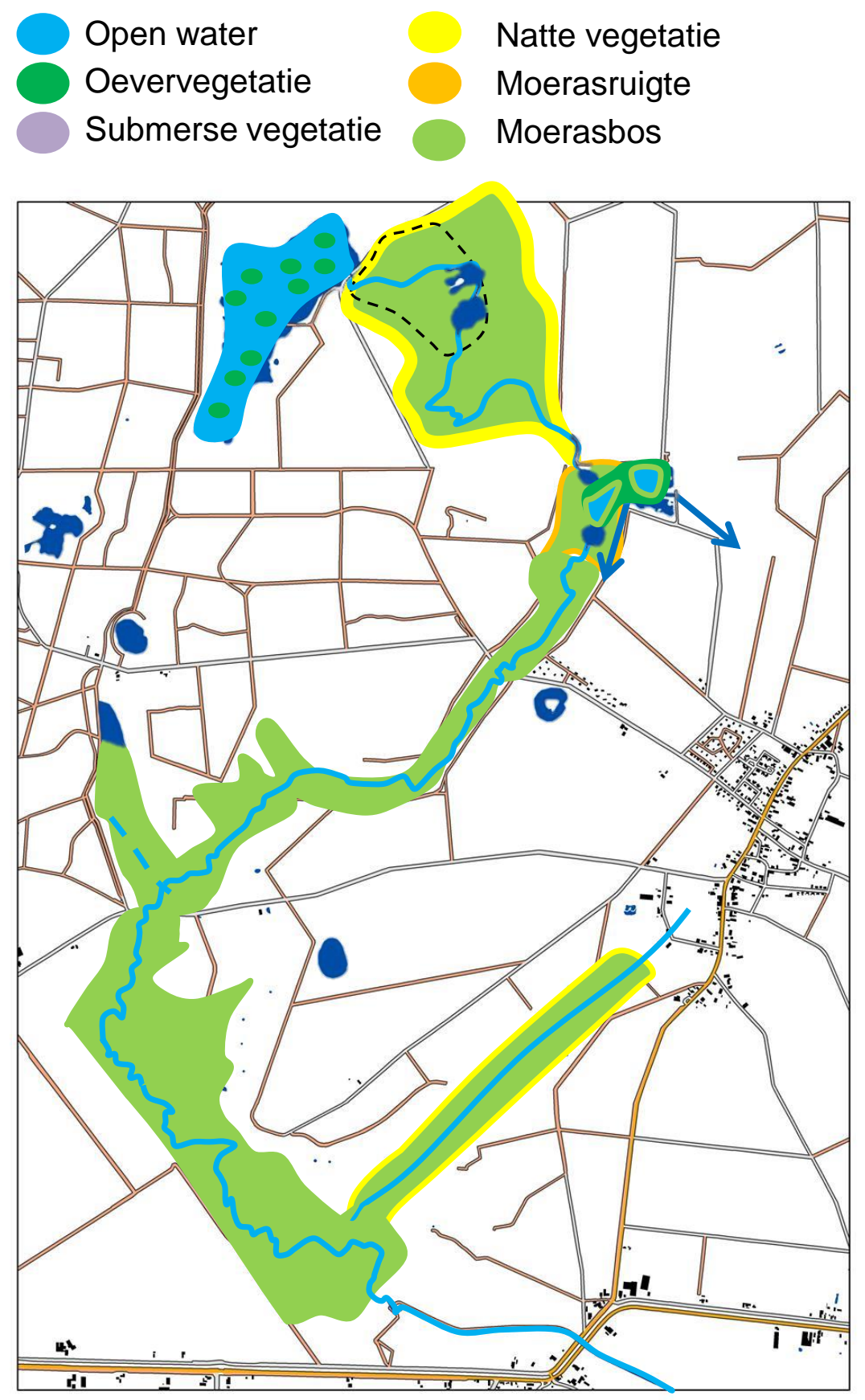

Figuur 6.3 Scenario 3. 


\section{Cultuurhistorisch perspectief}

De verschillende voorkeur deelscenario's wijken af van het in 2004 beschreven streefbeeld. In hoeverre hier vanuit cultuurhistorisch perspectief naar wordt gekeken is voorgelegd aan Theo Spek. De conclusie uit de discussie en het veldbezoek van de heren Spek en Grootjans aan het gebied was dat het herstellen van de houtwallen in het smalle beekdal tussen Mepper Hooilanden en het zuidelijk deel niet echt een optie is. Er zijn al veel bomen dood en aanplanten van nieuwe bomen is ook niet zinvol. Theo Spek is het ermee eens dat het laten ontwikkelen van een Elzenbroek daar vanuit cultuurhistorisch oogpunt niet onjuist is omdat het er voor de middeleeuwen ook is geweest. De optie om die Elzen aan te planten, om het bos snel te laten ontwikkelen, heeft voorkeur boven plaggen van de bovenlaag, want daar liggen heel waarschijnlijk relicten van gebruiksvoorwerpen. Vooral omdat de omgeving al heel lang door mensen is gebruikt. In het zijbeekdal vanaf Gees (Oude maden) is, gelet op de huidige inrichting, het terugdraaien van de vernatting ook geen optie, maar het beekdal kan daar wel veel opener worden gehouden. Je hebt dan wel je een beheer met rupsmaaiers nodig om biomassa (mogelijk niet jaarlijks) te oogsten. Wanneer geplagd gaat worden kunnen relicten en landschapselementen worden behouden door betreffende plekken of elementen te behouden en mogelijk zelfs met open houden of aanplanten te accentueren. 


\section{Monitoring moerasbosontwikkeling Geeserstroom}

Monitoren is het volgen van processen in de tijd, om onderweg: i) te kunnen bijsturen en ii) om te leren. Het is onmogelijk alle processen te monitoren, al was het maar om financiële redenen. Een monitoringsprogramma heeft altijd een doel. Hier is dat de vinger aan de pols houden of de moerasbosontwikkeling in de gewenste richting verloopt en de eutrofiëringseffecten verminderen, terwijl het af te voeren water continu naar benedenstrooms kan bewegen zodat (lokaal) geen overlast situaties in het aangrenzend landbouwgebied ontstaan.

Uit de belangrijkste processen in de moerasbosontwikkeling (figuur x) kunnen de belangrijkste doelen in termen van processen worden afgeleid:

- voldoende afstroming en passende grondwaterstanden

- ontwikkeling van elzenbroekbos en ruigte

- daling van de nutriëntenuitspoeling

- ontwikkelen van een laaglandbeekgemeenschap

De monitoring kan in twee categorieën worden verdeeld: monitoring ten behoeve van i) beheerdoelen en ii) ecologische ontwikkeling en kwaliteitsdoelen.

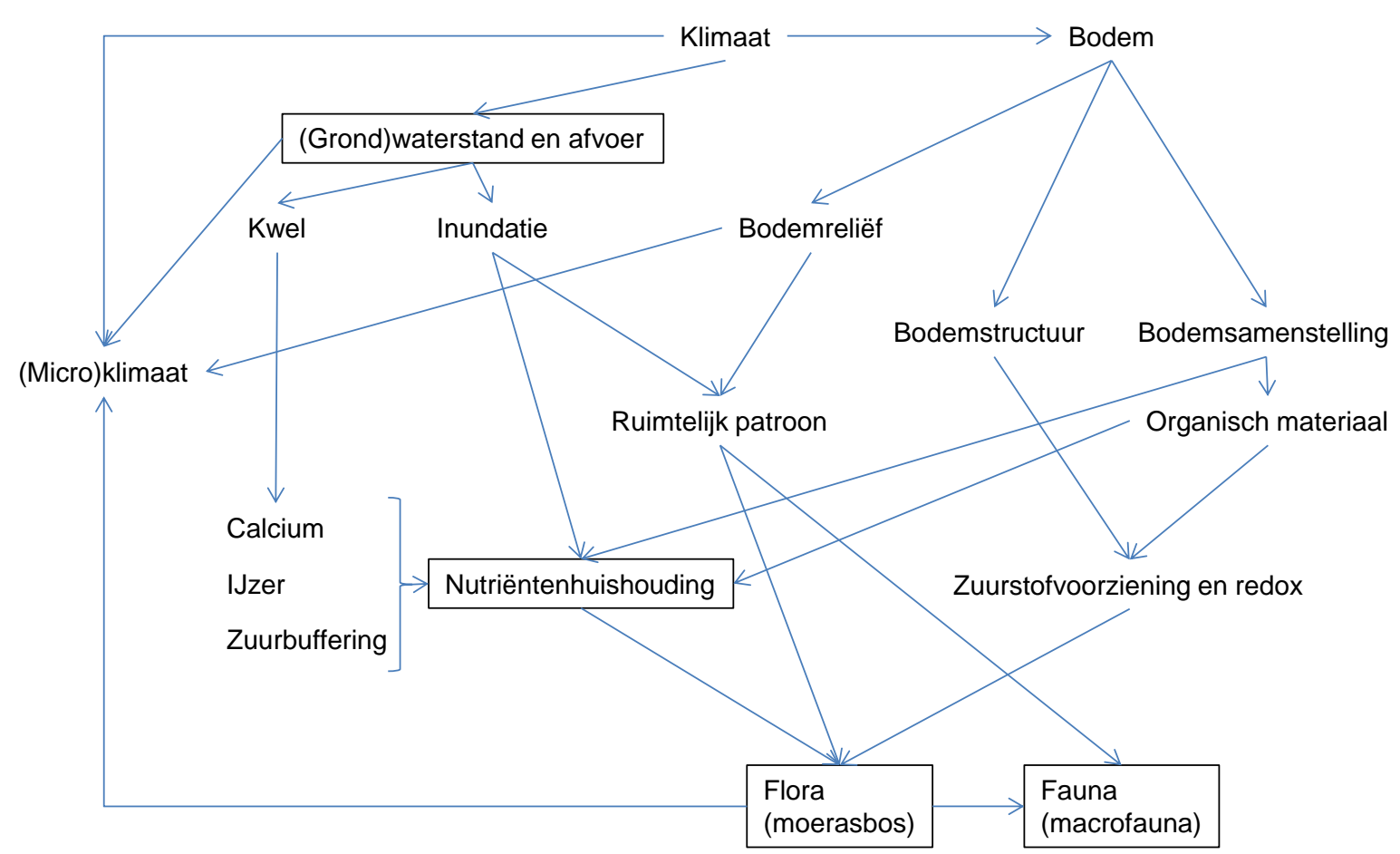

Figuur 7.1 Relatieschema van belangrijke sleutelfactoren en-processen in het te ontwikkelen moerasbos langs de Geeserstroom. De blokken geven de belangrijkste te monitoren componenten aan.

Monitoren is niet alleen het volgen van bepaalde processen in ruimte en tijd (figuur $7.1,7.2$ ) maar ook het verzamelen van (soms eenmalige) informatie om de processen te kunnen verklaren. Zo kan de herkomst, de hoeveelheid en de samenstelling van het kwelwater uit de westflank worden gemeten. Ook de aanwezige hoeveelheid nutriënten kan per bodemtype en historisch landgebruik worden vastgesteld om de nalevering in te schatten. 


\section{Monitoring voor beheerdoelen}

\section{Waterberging}

Om de hoeveelheid water dat geborgen wordt in het gebied na extreme neerslag te bepalen, is het opstellen van een waterbalans (met de termen IN: inlaat, kwel, neerslag en UIT: verdamping, wegzijging, uitstroom) voor en na de neerslagperiode nodig.

\section{Voldoende afstroming en passende grondwaterstanden}

Om de afstroming en grondwaterstanden goed in beeld te krijgen is naast een waterbalans (met de termen IN: inlaat, kwel, neerslag en UIT: verdamping, wegzijging, uitstroom) een aantal continu metingen nodig:

Afvoer: continu metingen bij de Tilweg, de zijloop uit Gees en benedenstrooms, naast een ijking en daarna het registreren van de hoeveelheid water dat bij Bollema wordt ingelaten. Grondwater: Voor het in beeld krijgen van het verloop van de grondwaterstanden zijn transecten (figuur 7.2) met meetbuizen nodig die loodrecht staan op de beek, met 1 buis in de beek waarmee de inundatie mee wordt genomen/geregistreerd. De transecten nemen zowel het moerasbosgedeelte en de aangrenzende laaggelegen landbouwpercelen mee. Lengte- en dwarsprofielontwikkeling beek en dal: Het lengteprofiel kan afgeleid worden aan de hand van luchtfoto's, zodat de ontwikkeling op de schaal van het hele dal gevolgd kan worden. Het dwarsprofiel wordt op enkele trajecten jaarlijks ingemeten. Tevens wordt jaarlijks het lengteprofiel nagelopen op eventuele lokale obstakels, vooral het dichtgroeien van het dwarsprofiel moet worden vastgelegd (locatie en trajectlengte).

Vegetatieontwikkeling in de beek: De vegetatieontwikkeling in de beek wordt in de zomer opgenomen in termen van percentage bedekking van oever, emerse, drijvende en submerse plantensoorten.

\section{Monitoring voor ecologische ontwikkeling en kwaliteit}

\section{Ontwikkeling van elzenbroekbos en ruigte}

De ontwikkeling van elzenopslag begint bij het uitgangspunt; een spontane ontwikkeling die geïnitieerd is door plaggen, een ingezaaid beekdalgedeelte of een ingeplant gebied. Jaarlijks kan de ontwikkeling in permanente kwadraten worden opgenomen in termen van aantal zaailingen en boomhoogte/stamdikte. Daarnaast kan gebruik worden gemaakt van luchtfoto's om de ontwikkeling over het hele dal te volgen.

\section{Dalen van de nutriëntenuitspoeling}

De nutriëntenbelasting is momenteel nog erg hoog. Het lijkt erop dat een sterke uitspoeling uit de voormalige landbouwgronden de oorzaak is. Door het frequent meten van stikstof en fosfaat bovenstrooms gemaal Bollema, voor of na Bollema en benedenstrooms kan jaarlijks een nutriëntenbalans (termen IN: uit- en afspoeling (intern en extern), inlaat, atmosferische depositie, kwel; RETENTIE: denitrificatie en tijdelijke en permanente opslag; UIT: uitstroom vracht) worden opgesteld.

\section{Ontwikkelen van een laaglandbeek en dal gemeenschap}

De laaglandbeekgemeenschap wordt op basis van de indicatorgroep macrofauna gevolgd. Tweemaal per jaar worden op drie locaties monsters genomen waarbij telkens onderscheid gemaakt wordt tussen een deelmonster van de habitats in de beekloop en een deelmonster 
van de habitats het moeras. Dit kan volgens standaardnet methode of een Quick-Scan, waarbij op het oog herkenbare families worden gescoord. De gegevens worden diagnostisch geëvalueerd.

Het moeraskarakter van de dal gemeenschap wordt gemonitord op basis van loopkevervangsten. Loopkevers zijn belangrijke hydromorfologische indicatoren en daardoor goed bruikbaar om beekherstel mee te evalueren. De locaties van de loopkevervallen worden gekoppeld aan de grondwaterbuizen, m.a.w. transecten dwars op de beek tot aan de gebiedsgrens met het landbouwgebied. Mocht de vegetatie ook meegenomen willen worden (optioneel) dan worden vergelijkbare transecten met Tansley techniek opgenomen.

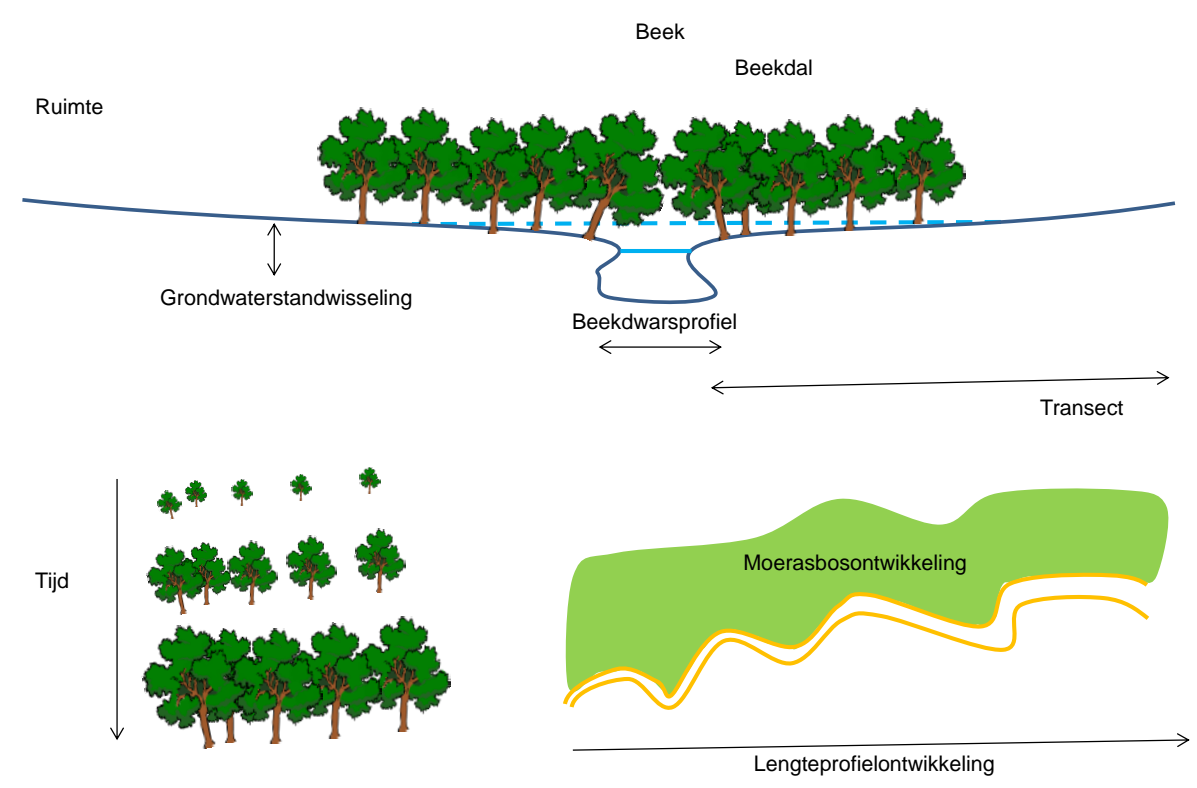

Figuur 7.2 Schets van de schaal in ruimte en tijd en termen die duiden op de belangrijkste te monitoren componenten van het beekdalsysteem. 


\section{Dankwoord}

Hierbij willen we het Kennisbasisprogramma Building with Nature (KB-24-001-007) bedanken voor hun financiële bijdrage. Daarnaast willen we eenieder die betrokken is geweest in dit project bedanken voor de prettige samenwerking. We willen het project OBN 2013-44-BE 'Integraal natuurherstel in beekdalen door ontwikkeling van diffuse afvoersystemen, gedempte afvoerdynamiek en genuanceerd beekprofielherstel' wat uitgevoerd wordt in opdracht van het Bosschap en met een financiële bijdrage van het ministerie van EZ, bedanken voor de nauwe interactie en het bieden van een breder kader voor en ondersteuning van deze studie. 


\section{Literatuur}

Adis, J., 1997. Terrestrial invertebrates: survival strategies, group spectrum, dominance and activity patterns. In: Junk, W.J. (ed.) The Central Amazon floodplain. Ecology of a pulsing system. Ecological studies 126. Springer, Berlin. P. 299-317.

Adis, J., Junk, W.J., 2002. Terrestrial invertebrates inhabiting lowland river floodplains of Central Amazonia and Central Europe: a review. Freshwater Biology 47, 711-731.

Aerts, R., van Logtestijn, R. S. P. \& Karlsson, P.S., 2006. Nitrogen supply differentially affects litter decomposition rates and nitrogen dynamics of sub-arctic bog species. Oecologia 146: 652-658.

Aggenbach, C.J.S., R.C.M. Verdonschot, H.H. de Vries, D. Groenedijk, J.P. Dijkstra \& R. van Diggelen, 2014. Effecten van maaibeheer op kleine zeggenmoerassen in beekdalen. Effecten op vegetatiestructuur, microtopografie en faunagemeenschappen. Directie Agrokennis, Ministerie van Economische zaken.

Akermans, A.D.L., 1971. Nitrogen-fixation and nodulation of Alnus and Hippophaë under natural conditions. Proefschrift, Universiteit Leiden.

Alterra, 2001. Handboek Robuuste Verbindingen; ecologische randvoorwaarden. Wageningen, Alterra, Research Instituut voor de Groene Ruimte.

Ambsdorf, J., 1996. Phytophage Arthropoda in verschiedenen Erlenbeständen (Alnus glutinosa) der Bornhöveder Seenkette unter besonderer Berücksichtigung des Kronenraumes. Faunistisch-Ökologische Mitteilungen Supplement 20, 77-110.

Arnolds, E. \& M. Veerkamp, 2008: Basisrapport Rode Lijst Paddenstoelen. Nederlandse Mycologische Vereniging, Utrecht.

Aukema, B., 2002. De schaatsenrijder Gerris lateralis in Nederland: vleugelpolymorfie, identificatie, biologie en verspreiding (Heteroptera: Gerridae). Nederlandse Faunistische Mededelingen 17, 1-11.

Baeten, L., Hermy, M., Verheyen, K. 2009. Environmental limitation contributes to the differential colonization capacity of two forest herbs. Journal of Vegetation Science 20: 209-223.

Batzer, D.P., Cooper, R., Wissinger, S.A., 2006. Wetland animal ecology. In: Batzer, D.P., Sharitz, R.R. (eds.) Ecology of freshwater and estuarine wetlands. University of California Press, Berkeley. P. pg. 242-284.

Berg, M., Evenhuis, C., 2001. Determinatietabel voor de Nederlandse duizendpoten (Myriapoda: Chilopoda). Nederlandse Faunistische Mededelingen 15, 41-78.

Beylich, A., Graefe, U., 2002. Annelid coenoses of wetlands representing different decomposer communities. In: Broll, G., Merbach, W., Pfeiffer, E.-M. (eds.) Wetlands in Central Europe: Soil organisms, soil ecological processes and trace gas emmisions. Springer, Berlin. P. 1-10.

Bilton, D.T., Freeland, J.R., Okamura, B., 2001. Dispersal in freshwater invertebrates. Annual Review of Ecology and Systematics 32, 159-181.

Binkley, D., Sollins P., Bell, R., Sachs, D. \& Myrold D. (1992) Biogeochemsitry of adjacent conifer and alder-conifer stands. Ecology 73: 2022-2033.

Boesveld, A., 2005. Inventarisatie van de landslakken van Noord-Brabant. Rapport EIS200502. Stichting European Invertebrate Survey Nederland, Leiden.

Braccia, A., Batzer, D.P., 2001. Invertebrates associated with woody debris in a Southeastern U.S. forested floodplain wetland. Wetlands 21, 18-31. 
Carlson, PJ. and J.0. Dawson, 1985. Soil nitrogen changes, early growth, and response to soil internal drainage of a plantation of Alnus jorullensis in the Colombian highlands. Turrialba 35(2):141-150.

Churchfield, S., \& Rychlik, L., 2006. Diets and coexistence in Neomys and Sorex shrews in Białowieża forest, eastern Poland. Journal of Zoology, 269(3), 381-390.

Coleman, D.C., Crossley, D.A., Hendrix, P.F., 2004. Fundamentals of soil ecology. Elsevier Academic Press, Burlington.

Compton J.E. \& Cole D.W. (1998) Phosphorus cycling and soil P fractions in Douglas-fir and red alder stands. Forest Ecology and Management 110: 101-112.

Darell, P., Cronberg, N., 2011. Bryophytes in black alder swamps in south Sweden: habitat classification, environmental factors and life-strategies Lindbergia 34, 9-29.

De Fré, B., Hoffmann, M., 2004. Systematiek van natuurtypen voor Vlaanderen: Struwelen en mantels (System of the nature types in Flanders: scrubs) [in Dutch]. - Brussels: Research Institute for Nature and Forest.

de Waal, R.W., Hommel, P.W.F.M. 2005. Abiotische typering van bostypen in Nederland; vochtregime, zuurgraad, voedselrijkdom en humusvormen (No. 1258). Alterra.

Didderen K., A. Besse-Lototskaya, M.W. van den Hoorn, J.A. Sinkeldam, R. Wiggers, P.F.M. Verdonschot, 2009. Herinrichting Geeserstroom; beschrijving van de monitoringsresultaten. Wageningen, Alterra, Alterra rapport 1790.

Disney, R.H.L., 1999. British Dixidae (meniscus midges) and Thaumaleidae (trickle midges): keys with ecological notes. Freshwater Biological Association.

Döbel, H.G., Denno, R.F., Coddington, J.A., 1990. Spider (Araneae) community structure in an intertidal salt marsh: Effects of vegetation structure and tidal flooding. Environmental Entomology 19, 1356-1370.

Dobrowolski, K. A., Kozakiewicz, A., \& Leźnicka, B., 1993. The role of small mammals and birds in transport of matter through the shore zone of lakes. Hydrobiologia, 251(1-3), 81-93.

Dossche, T., 1998. Ecologische effecten van bladstrooisel van loofboomsoorten op de ontwikkeling van recent beboste landbouwgronden (Mortagnebos-Zwevegem). Ghent University, Ghent.

Duursema, G., \& Torenbeek, R., 1997. Beken in Drenthe: een onderzoek naar ecologie en natuur op basis van macro-invertebraten. Zuiveringsschap Drenthe.

Eriksen, C.H., Resh, V.H., Balling, S.S., Lamberti, G.A., 1984. Aquatic insect respiration. In: Merritt, R.W., Cummins, K.W. (eds.). An introduction to the aquatic insects of North America. 2nd edition. Kendall/Hunt Publishing Company, Dubuque. P. 27-37.

Giardina, C.P., Huffman, S., Binkley, D. \& Caldwell, B.A., 1995. Alders increase soil phosphorus vailability in a Douglas-fir plantation. Canadian Journal of Forestry Research 25: 1652-1657. Disney, R.H.L., 1999. British Dixidae (meniscus midges) and Thaumaleidae (trickle midges): keys with ecological notes. Freshwater Biological Association, Ambleside.

Gilbert, J.C., Gowing, D.J.G. \& R.J. Bullock, 2003. Influence of seed mixture and hydrological regime on the establishment of a diverse grassland sward at a site with high phosphorus availability. Restoration Ecology 11: 424-435.

Griffioen, C.J.H. \& Pitlo, R.H., 1991. Stromingsmodel voor begroeide waterlopen. Waterschapsbelangen 10, 345-348.

Groeneweg M. 2000. De vegetatie van de Mars- en Geeserstroom (Boswachterij Gees). Altenburg \& Wymenga Ecologisch Onderzoek, Veenwouden. A\&W rapport 228. 
Grootjans, A.P., Adema, E.B., \& Everts, F.H., 2004. Effectgerichte maatregelen tegen verdroging, verzuring en stikstofdepositie in natte duinvalleien in het Waddendistrict (Texel en Terschelling). Expertisecentrum LNV.

Hamdi, Y.A.M., 1982. Application of nitrogen-fixing systems in soil improvement and management. FAO Soil Bulletins. FAO, Rome.

Hannig, K., Schäfer, F., Brandt, T., 2006. Zur Laufkäferfauna (Coleoptera: Carabidae) ausgewählter Lebensräume am Südwestufer des Steinhuder Meeres, Niedersachsen. Braunschweiger naturkundliche Schriften 7, 639-652.

Hanski, I., 1999. Metapopulation Ecology. Oxford University Press, Oxford.

Hendriks, R.F.A., 1992. Afbraak en mineralisatie van veen. Rapport 199. Staring Centrum, Wageningen.

Higler, L.W.G., 2008. Verspreidingsatlas Nederlandse kokerjuffers (Trichoptera). European Invertebrate Survey Nederland, Leiden.

Kalkhoven, J.T.R., A.H.P. Stumpel, S.E. Stumpel-Rienks, 1976. Landelijke Milieukartering. Staatsuitgeverij, 's-Gravenhage.

Knollenberg, W.G., Merritt, R.W., Lawson, D.L., 1985. Consumption of leaf Litter by Lumbricus terrestris (Oligochaeta) on a Michigan woodland floodplain. American Midland Naturalist 113, 1-6.

Kroes, J. G., \& Van Dam, J. C. (2003). Reference manual SWAP version 3.0. 3.

Lambeets, K., Vandeheguchte, M.L., Maelfait, J.-P., Bonte, D., 2009. Integrating environmental conditions and functional life-history traits for riparian arthropod conservation planning. Biological Conservation 142, 625-637.

Leibold, M.A., Holyoak, M., Mouquet, N., Amarasekare, P., Chase, J.M., Hoopes, M.F., Holt, R.D., Shurin, J.B., Law, R., Tilman, D., Loreau, M., Gonzalez, A., 2004. The metacommunity concept: a framework for multi-scale community ecology. Ecology Letters 7, 601-613.

Levins, R., 1969. Some demographic and genetic consequences of environmental heterogeneity for biological control. Bulletin of the Entomological Society of America 15, 237-240.

Luff, M.L., 1966. The abundance and diversity of the beetle fauna of grass tussocks. Journal of Animal Ecology 35, 189-208

Lundkvist, E., Landin, J., Jackson, M., Svensson, C., 2003. Diving beetles (Dytiscidae) as predators of mosquito larvae (Culicidae) in field experiments and in laboratory tests of prey preference. Bulletin of Entomological Research 93, 219-226.

Maelfait, J.-P., De Knijf, G., De Becker, P., Huybrechts, W., 1995. In: Růžička, V. (ed.) Proceedings of the 15th European Colloqium of Archnology. Institute of Entomology, České Budĕjovice. P. 125-135.

Mendelsson I.A., Batzer, D.P., 2006. Abiotic constraints for wetland plants and animals. In: Batzer, D.P., Sharitz, R.R. (eds.) Ecology of freshwater and estuarine wetlands. University of California Press, Berkeley. P. 82-114.

Moller Pillot, H.K.M., 1984. De larven der Nederlandse Chironomidae (Diptera): Orthocladiinae sensu lato. Nederlandse Faunistische Mededelingen 1B, 1-175.

Móra, A., Csabai, Z., Boda, P., 2004. Larval data to the caddisfly fauna of the Szuha stream and its environments, NE Hungary (Trichoptera). Folia Hisctorico Naturalia Musei Matraensis 28, 165-170.

Nickel, A., Pelz, O., Hahn, D., Saurer, M., Siegwolf, R. \& Zeyer, J., 2002. Effects of Inoculation and Leaf Litter Amendment on Establishment $f$ Nodule-Forming Frankia Populations in Soil. Applied and Environmental Microbiology 67: 2603-2609. 
Nötzold, R., 1996. Die Kurzflügel- und Laufkäfergemeinschaften (Staphylinidae und Carabidae) des Bodems verschiedener Erlenbruchbiotope im Raum Bornhöved und ihre Abhängigkeit von Standortfaktoren. Faunistisch-Ökologische Mitteilungen Supplement 20, 9-46.

Olde Venterink, H., J.E. vermaat, M. Pronk, F. Wiegman, G.E.M. van der Lee, M.W. van den Hoorn, L.W.G. Higler \& J.T.A. Verhoeven, 2002. Importance of sedimentation and denitrification for plant productivity and nutrient retention in various floodplain wetlands along the river Rhine. In: Hoekstra, A.Y., H. Olde Venterink, E.F.W. Ruijgh en G.E.M. van der Lee (Eds.). Evaluation of floodplain management strategies: the added value of wetland rehabilitation. IRMA-SPONGE project no.8

Orczewska, A., 2009. The impact of former agriculture on habitat conditions and distribution patterns of ancient woodland species in recent black alder (Alnus glutinosa (L.) Gaertn.) woods in south-western Poland. Forest Ecology and Management 258: 794803.

Persson Vinnersten, T.Z., Lundström, J.O., Schäfer, M.L., Petersson, E., Landin, J., 2010. A six-year study of insect emergence from temporary flooded wetlands in central Sweden, with and without Bti-based mosquito control. Bulletin of Entomological Research 100, 715-725.

Pižl, V., 1999. Earthworm communities in hardwood floodplain forests of the Morava and Dyje rivers as influenced by different indundation regimes. Ekológia 18 (S1), 197-204.

Poels, R.L.H., P. Schmidt, J. van den Burg, R.H. Kemmers \& H.A. Verhoef, 2000. Pre-advies Natte Bossen. Verdroging, verzuring en eutrofiëring van natte bossen in Nederland: effecten en maatregelen. OBN-rapport nr. 01. IKC natuurbeheer LNV, Wageningen.

Prescott, C.E., 2002. The influence of the forest canopy on nutrient cycling. Tree Physiology 22:1193-1200.

Rief, S., 1996. Einfluss der Bewirtschaftung auf ausgewählte Diptera (Nematocera: Limnoniidae; Tipulidae; Trichoceridae; Brachycera: Empididae; Hydotidae; Dolichopodidae) verschiedener Ökosysteme auf Niedermoortorfen. FaunistischÖkologische Mitteilungen Supplement 20, 47-76.

Riegel, T., 1996. Zur Carabidenfauna von Waldgesellschaften underschiedlicher Feuchtestufen in einem ostniedersächsichen Waldgebiet. Braunschweiger naturkundliche Schriften 5, 35-53.

Rodriguez-Barrueco, C., Miquel C. \& Subramaniam P. (1984) Seasonal fluctuations of the mineral concentration of alder (Alnus glutinosa (L.) Gaertn.) from the field. Plant and Soil 78: 201-208.

Runhaar, J., Lucassen, E.C.H.E.T., Smolders, A.J.P., Verdonschot, R.C.M., \& Hommel, P.W.F.M., 2013. Herstel broekbossen (No. 2013/OBN169-BE, p. 135). Bosschap.

Schäfer, M.L., Lundström, J.O., Petersson, E., 2008. Comparison of mosquito (Diptera: Culicidae) populations by wetland type and year in the lower River Dalälven region, Central Sweden. Journal of Vector Ecology 33, 150-157.

Schaminée, J. H. J., Stortelder, A. H. F., Westhoff, V., 1995. De vegetatie van Nederland 1. inleiding tot de plantensociologie: grondslagen, methoden en toepassingen. Uppsala/Leiden: Opulus Press. p, 296.

Ścibior, R., Dunus, W., 2006. Preservation degree of wet biotopes of the Kozłowiecki landscape park based on the biodiversity of leaf beetles (Coleoptera: Chrysomelidae). Acta Agrophysica 7, 495-502. 
Selmants, P.C., Hart, S.C., Boyle, S.I., Stark, J.M., 2005. Red alder (Alnus rubra) alters community-level soil microbial function in conifer forests of the Pacific Northwest, USA. Soil Biology and Biochemistry 37: 1860-1868

Sharitz, R.R., Batzer, D.P., 1999. An introduction to freshwater wetlands in North America and their invertebrates. In: Batzer, D.P., Rader, R.B., Wissinger, S.A. (eds.) Invertebrates in freshwater wetlands of North America: Ecology and management. John Wiley \& Sons, New York. P. 1-24.

Siebel, H.N., 1998. Floodplain forest restoration. Tree seedling establishment and tall herb interference in relation to flooding and shading. IBN Scientific Contributions nr. 9. IBN-DLO, Wageningen.

Smolders, A.J.P., Lucassen, E.C.H.E.T., Bobbink, R., Roelofs, J.G.M. \& Lamers, L.P.M., 2010. How nitrate leaching from agricultural lands provokes phosphate eutrophication in groundwater fed wetlands: the sulphur bridge. Biogeochemistry 98: 1-7.

Stańska, M., 2007. Rare and threatened spider species (Araneae) in selected types of deciduous forests in the Białowieża Forest. Nature Conservation 64, 13-29.

Stańska, M., Hajdamowicz, I., Żabka, M., 2002. Epigeic spiders of alder swamp forests in Eastern Poland. Proceedings of the 19th European Colloqium of Archnology, Århus University Press, Århus. P. 191-197.

Stegner, J., 1998. Untersuchungen zur Laufkäferfauna (Col., Carabidae) ausgewählter Waldflächen im Spreewald. Entomologische Nachrichten und Berichte 42, 205-210.

Stortelder, A.H.F., Hommel, P.W.F.M., De Waal, R.W., Van Dort, K.W., Vrielink, J.G \& R.J.A.M. De Wolf, 1998. Broekbossen. Natuurhistorische Bibliotheek nr 66. KNNV, Utrecht.

Stortelder, A.H.F., J.H.J. Schaminée en P.W.F.M. Hommel, 1999. De vegetatie van Nederland. Deel 5: Ruigten, struwelen en bossen. Opulus Press, Uppsala/Leiden.

Tajovský, K., 1999. Impact of inundations on terrestrial arthropod assemblages in southern Moravian floodplain forests, The Czech Republic. Ekológia 18 (S1), 177-184.

Tajovský, K., Wytwer, J., 2009. Millipedes and centipedes in wetland alder stands in northeastern Poland. Soil Organisms 81, 761-772.

Taylor, A.N., Batzer, D.P., 2010. Spatial and temporal variation in invertebrate consumer diets in forested and herbaceous wetlands. Hydrobiologia 651, 145-159.

Thomaes, A., De Keesmaeker, L., De Schrijver, A., Vandekerkhove, K., Verschelde, P. \& K. Verheyen, 2011. Can tree species choice influence recruitment of ancient forest species in post-agricultural forest? Plant Ecology 212: 573-584.

Tickner, D. P., Angold, P. G., Gurnell, A. M., Mountford, J. O., \& Sparks, T. (2001). Hydrology as an influence on invasion: Experimental investigations into competition between the alien Impatiens glandulifera and the native Urtica dioica in the UK. Plant Invasions: Species Ecology and Ecosystem Management. Leiden, Netherlands: Blackhuys Publishers, 159-168.

Torenbeek, R., 1999. Nutriënten in Drentse oppervlaktewateren : een analyse van knelpunten en oorzaken. Zuiveringschap Drenthe. 40 pp.

Torenbeek, R., van Gijsen, M.E.A., 1990. Ecologische doelstellingen en beoordelingsmethode voor stromende wateren. Zuiveringschap Drenthe.

Turin, H., 2000. De Nederlandse loopkevers. Verspreiding en oecologie (Coleoptera: Carabidae). Nederlandse Fauna 3. Nationaal Natuurhistorisch Museum Naturalis, KNNV Uitgeverij en EIS-Nederland, Leiden. 
Uetz, G.W., Van Der Laan, K.L., Summers, G.F., Gibson, P.A.K., Getz, L.L., 1979. The effects of flooding on floodplain arthropod distribution, abundance and community structure. American Midland Naturalist 101, 286-299.

Valdez, M., 2008. Frankia Ecology In: Nitrogen-fixing Actinorhizal Symbioses, pp.49-71 (K. Pawlowski and W. E. Newton (eds.), Springer.

Van der Hoek, W.F., Cuppen, J.G.M., 1989. Life cycle and growth of Trichostegia minor (Curtis) in temporary woodland pools (Trichoptera: Phryganeidae). Aquatic Ecology 23, 161-168.

Van der Valk, A.G., 2006. The biology of freshwater wetlands. Oxford University Press, Oxford.

Van der Veen K. 2009. De vegetatie en flora van de Mars- en Geeserstroom. Altenburg \& Wymenga Ecologisch Onderzoek, Veenwouden. A\&W rapport 1242.

Van der Werf, S., 1991. Bosgemeenschappen. Natuurbeheer in Nederland deel 5. Pudoc, Wageningen.

Vercoutere, B., 2002. De zeggekorfslak in België en Nederland. De Levende Natuur 103, 1621.

Verdonschot, Ralf, Verdonschot, Piet, 2012. Gegevensanalyse van de macrofaunamonitoringsgegevens van het herstelproject Geeserstroom. Alterra, Notitie Zoetwaterecosystemen.

Verheyen, K., Guntenspergen, G., Biesbrouck, B., Hermy, M., 2003. An integrated analysis of the effects of past land-use on forest plant species colonization at the landscape scale. Journal of Ecology 91: 731-742.

Vitousek, P.M. \& Howarth, R.W., 1991. Nitrogen limitation on land and in the sea: How can it occur? Biogeochemistry 13: 87-115.

Werkgroep Geeserstroom, 2004. Inrichtingsplan Geeserstroom. Dienst Landelijk gebeid. T. de Meij (Waterschap Velt en Vecht), E. Lammerts en B. de Jong (Staatsbosbeheer) en R. Hofstra (Dienst Landelijk Gebied Drenthe)(eindredatie).

Wesołowski, T., Rowiński, P., Mitrus, C., \& Czeszczewik, D., 2006. Breeding bird community of a primeval temperate forest (Białowieża National Park, Poland) at the beginning of the 21st century. Acta Ornithologica, 41(1), 55-70.

Wiggins, G.B., Mackay, R.J., Smith, I.M., 1980. Evolutionary and ecological strategies of animals in annual temporary pools. Archiv für Hydrobiologie Supplement 58, 97-206.

Williams, D. D. (1996). Environmental constraints in temporary fresh waters and their consequences for the insect fauna. Journal of the North American Benthological Society, 634-650.

Williams, D.D., 2005. Temporary forest pools; can we see the water for the trees? Wetlands Ecology and Management 13, 213-233.

Wissinger, S.A., 1999. Ecology of wetland invertebrates: Synthesis and applications for conservation and management. In: Batzer, D.P., Rader, R.B., Wissinger, S.A. (eds.) Invertebrates in freshwater wetlands of North America: Ecology and management. John Wiley \& Sons, New York. P. 1043-1086.

Wlodarczyk, T., 2010. Ant species composition in relation to forest associations in Szczecin Landscape Park. Polish Journal of Entomology 79, 91-99.

Wright, J. P., Jones, C. G., \& Flecker, A. S. (2002). An ecosystem engineer, the beaver, increases species richness at the landscape scale. Oecologia, 132(1), 96-101.

Zulka, K.P., 1994. Carabids in a Central European floodplain: species distribution and survival during inundations. In: Desender, K., Dufrene, M., Loreau, M., Luff, M.L., 
Maelfait, J.P. (eds.) Carabid Beetles: Ecology and Evolution. Kluwer Academic Publishers, Dordrecht.P. 399-405. 
Bijlagen 


\section{Bijlage 1 Selectie en parameterisatie van de proefplekken}

Locaties:

Voor de modelberekeningen met SWAP zijn 4 locaties geselecteerd:

\begin{tabular}{|c|c|c|c|c|c|c|c|}
\hline $\mathrm{Nr}$ & $\begin{array}{l}\text { X- } \\
\text { coord }\end{array}$ & $\begin{array}{l}\text { Y- } \\
\text { coord }\end{array}$ & Bodem & Gt & L_ontw & L_afw & L_totaal \\
\hline 1 & 240685 & 528385 & $a \vee z$ & II & 115 & 183 & 70 \\
\hline 2 & 241647 & 530210 & $\mathrm{Hn} 23$ & VI & 760 & 292 & 211 \\
\hline 3 & 242186 & 531019 & $v W z$ & Illb & 225 & 174 & 98 \\
\hline 4 & 241334 & 531718 & Hn23 & V & 130 & 3698 & 126 \\
\hline
\end{tabular}

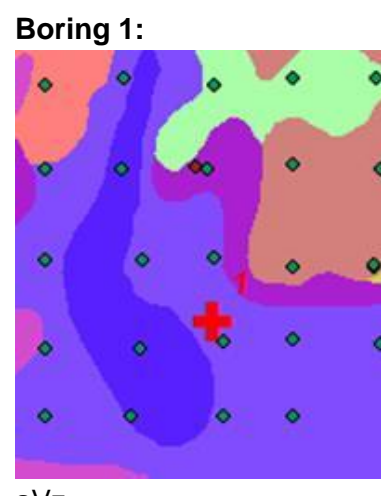

Geen keileem volgens keileemkaart

Boring: $\quad 528-240-0008$

Maaiveld

13.1 NAP

13.1-12.4 m-mv 6

12.4-11.9 m-mv 2

$11.0-11.6 \mathrm{~m}-\mathrm{mv} 3$

528-240-0005

13.1 $\mathrm{m}$ NAP

$13.1-12,2 \mathrm{~m}-\mathrm{mv} 6$

528-240-0004

$13.2 \mathrm{~m}+\mathrm{NAP}$

13.2-12.4 m-mv 6

$12.4-12.1 \mathrm{~m}-\mathrm{mv} 2$

12.1-11.7 m-mv 4

6-11.2 m-mv 2

wvp

11.7-11.1 m-mv 2

wvp

(70 $\mathrm{cm}$ veen)

(90 cm veen)

$(50 \mathrm{~cm}$ fijn zand)

$140 \mathrm{~cm}$ fijn zand 


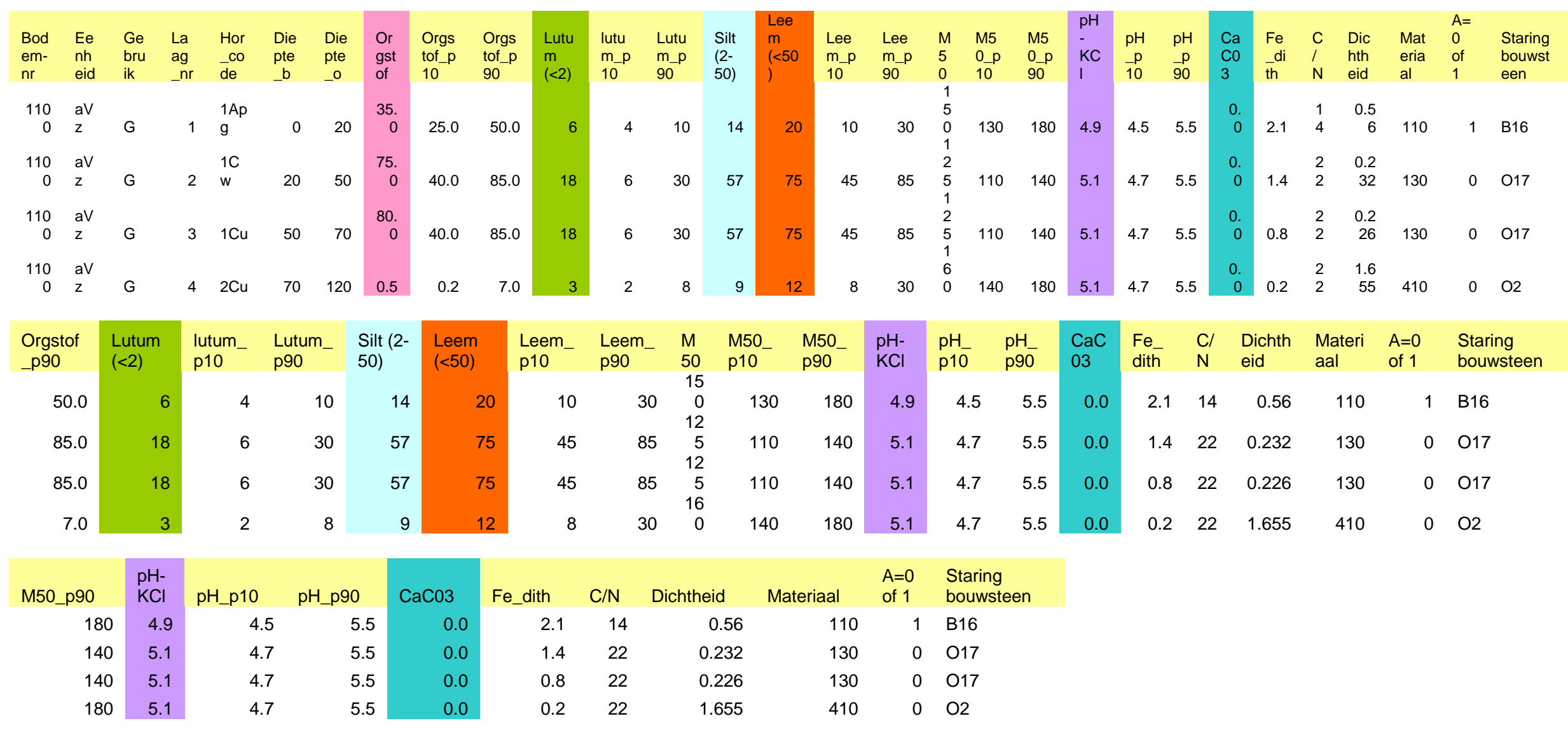

\section{Profiel boring 1}

Bovenkant Onderkant Staring bouwsteen

$\begin{array}{rrll}0 & 20 & \text { B16 } & \\ 20 & 80 & \text { O17 } & \text { Fijn zand } \\ 80 & 150 & \text { O2 } & \text { Watervoerend pakket I } \\ 150 & 400 & \text { O5 } & \end{array}$




\section{Boring 2:}

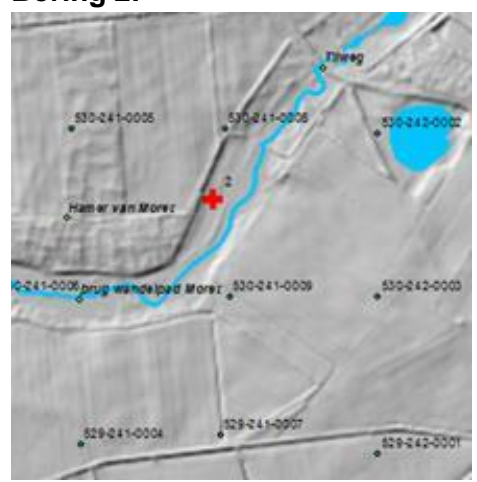

$\mathrm{Hn} 23$

Keileem top 0,04-3.52 m-mv, 14.39 - 10.91 m +NAP, dikte 3,48 m

Boring:

530-241-0008

15.3 NAP

15.3-15.0 m-NAP 1

15.0-14.9 m-NAP 6

14.9 - 14.4 m-NAP 2

$14.4-14.3$ m-NAP 1

$14.3-11.68$ m-NAP 5

wvp

$(272 \mathrm{~cm}$ keileem $)$
530-241-00093

$15.4 \mathrm{~m}$ NAP

$15.4-14.9$ m-NAP 1

14.9-14.7 m-NAP 2

14.7-14.1 m-NAP 5

14.1-13.9 m-NAP 2

13.9-13.7 m-NAP 5

13.7-13.5 m-NAP 2

13.5-12.11 m-NAP 5

wvp

(219 cm keileem) $\begin{array}{ll}530-241-0005 & 530-242-0002 \\ 15.8 \mathrm{~m}+\mathrm{NAP} & 15.1 \mathrm{~m}+\mathrm{NAP}\end{array}$

15.8-15.4 m-mv 1 15.1-14.9 m-mv 1

15.4-14.4 m-mv 2 14.9-14.0 m-mv 2

14.4-11.9 m-mv 5 14.0-12.6 m-mv 5

11.9-11.6 m-NAP $2 \quad 12.6-12.1$ m-mv 2

11.6-11.54 m-NAP $5 \quad$ wvp

wvp

(256cm keileem)

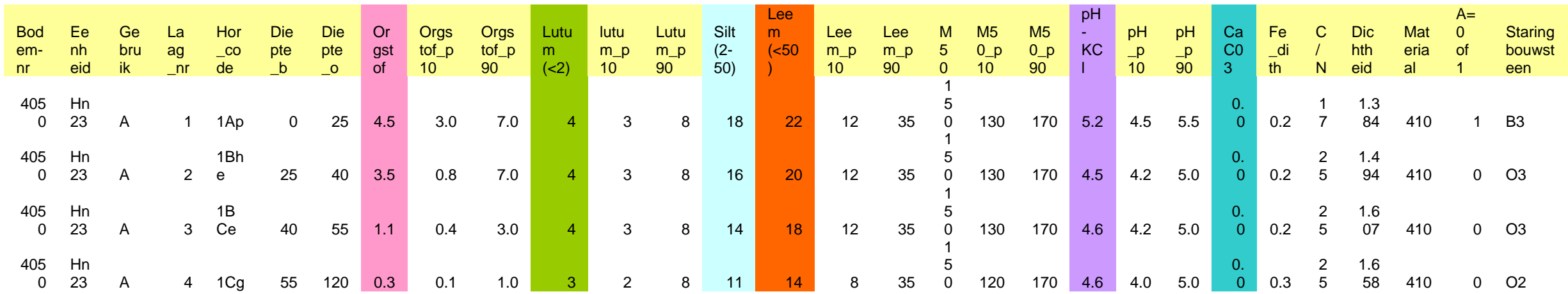




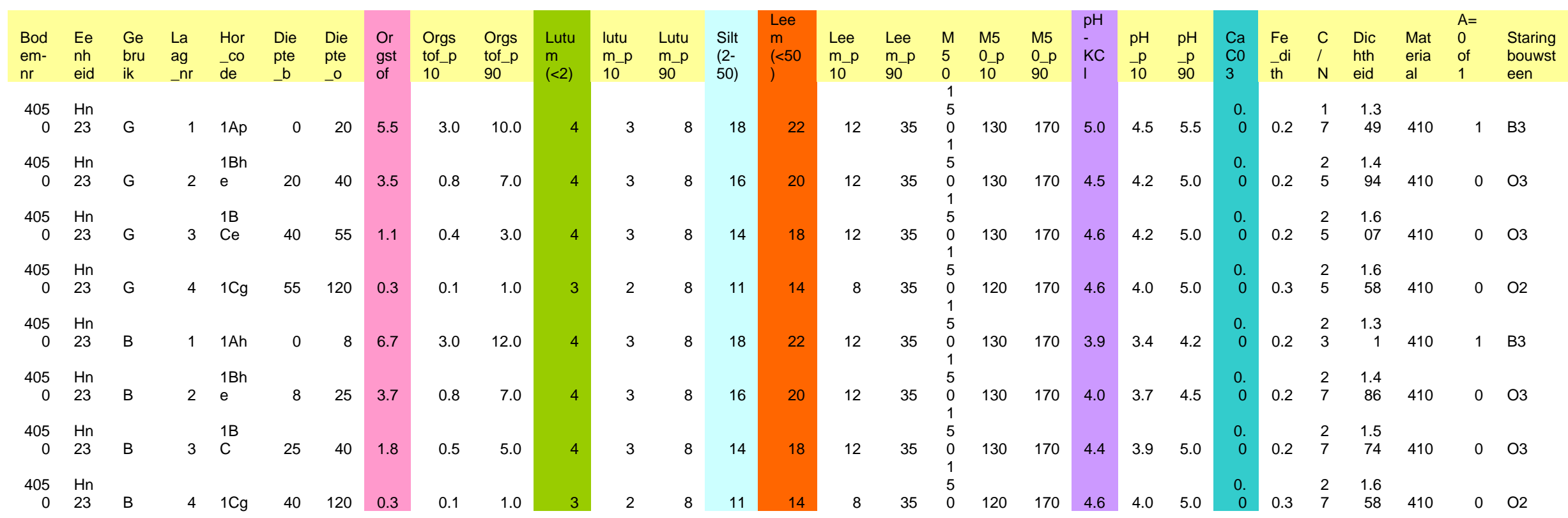

\begin{tabular}{|c|c|c|c|c|c|c|c|c|c|c|c|c|c|c|c|c|c|c|c|}
\hline $\begin{array}{l}\text { Lutum } \\
(<2)\end{array}$ & $\begin{array}{l}\text { lutum_ } \\
\text { p10 }\end{array}$ & $\begin{array}{l}\text { Lutum_ } \\
\text { p90 }\end{array}$ & $\begin{array}{l}\text { Silt (2- } \\
50)\end{array}$ & $\begin{array}{l}\text { Leem } \\
(<50)\end{array}$ & $\begin{array}{l}\text { Leem_ } \\
\text { p10 }\end{array}$ & $\begin{array}{l}\text { Leem_ } \\
\text { p90 }\end{array}$ & $\begin{array}{l}\text { M5 } \\
0\end{array}$ & $\begin{array}{l}\text { M50_p } \\
10\end{array}$ & $\begin{array}{l}\text { M50_p } \\
90\end{array}$ & $\begin{array}{l}\mathrm{pH}- \\
\mathrm{KCl}\end{array}$ & $\begin{array}{l}\mathrm{pH} \_\mathrm{p} \\
10\end{array}$ & $\begin{array}{l}\mathrm{pH} \_\mathrm{p} \\
90\end{array}$ & $\begin{array}{l}\mathrm{CaC} \\
03\end{array}$ & $\begin{array}{l}\text { Fe_d } \\
\text { ith }\end{array}$ & $\begin{array}{l}\mathrm{C} / \\
\mathrm{N}\end{array}$ & $\begin{array}{l}\text { Dichth } \\
\text { eid }\end{array}$ & $\begin{array}{l}\text { Materi } \\
\text { aal }\end{array}$ & $\begin{array}{l}A=0 \\
\text { of } 1\end{array}$ & $\begin{array}{l}\text { Staring } \\
\text { bouws }\end{array}$ \\
\hline 4 & 3 & 8 & 18 & 22 & 12 & 35 & $\begin{array}{r}15 \\
0 \\
15\end{array}$ & 130 & 170 & 5.2 & 4.5 & 5.5 & 0.0 & 0.2 & 17 & 1.384 & 410 & 1 & B3 \\
\hline 4 & 3 & 8 & 16 & 20 & 12 & 35 & $\begin{array}{r}0 \\
15\end{array}$ & 130 & 170 & 4.5 & 4.2 & 5.0 & 0.0 & 0.2 & 25 & 1.494 & 410 & 0 & O3 \\
\hline 4 & 3 & 8 & 14 & 18 & 12 & 35 & $\begin{array}{r}0 \\
15\end{array}$ & 130 & 170 & 4.6 & 4.2 & 5.0 & 0.0 & 0.2 & 25 & 1.607 & 410 & 0 & O3 \\
\hline 3 & 2 & 8 & 11 & 14 & 8 & 35 & $\begin{array}{r}0 \\
15\end{array}$ & 120 & 170 & 4.6 & 4.0 & 5.0 & 0.0 & 0.3 & 25 & 1.658 & 410 & 0 & $\mathrm{O} 2$ \\
\hline 4 & 3 & 8 & 18 & 22 & 12 & 35 & $\begin{array}{r}0 \\
15\end{array}$ & 130 & 170 & 5.0 & 4.5 & 5.5 & 0.0 & 0.2 & 17 & 1.349 & 410 & 1 & B3 \\
\hline 4 & 3 & 8 & 16 & 20 & 12 & 35 & $\begin{array}{r}0 \\
15\end{array}$ & 130 & 170 & 4.5 & 4.2 & 5.0 & 0.0 & 0.2 & 25 & 1.494 & 410 & 0 & O3 \\
\hline 4 & 3 & 8 & 14 & 18 & 12 & 35 & $\begin{array}{r}0 \\
15\end{array}$ & 130 & 170 & 4.6 & 4.2 & 5.0 & 0.0 & 0.2 & 25 & 1.607 & 410 & 0 & O3 \\
\hline 3 & 2 & 8 & 11 & 14 & 8 & 35 & $\begin{array}{r}0 \\
15\end{array}$ & 120 & 170 & 4.6 & 4.0 & 5.0 & 0.0 & 0.3 & 25 & 1.658 & 410 & 0 & $\mathrm{O} 2$ \\
\hline 4 & 3 & 8 & 18 & 22 & 12 & 35 & 0 & 130 & 170 & 3.9 & 3.4 & 4.2 & 0.0 & 0.2 & 23 & 1.31 & 410 & 1 & B3 \\
\hline 4 & 3 & 8 & 16 & 20 & 12 & 35 & 15 & 130 & 170 & 4.0 & 3.7 & 4.5 & 0.0 & 0.2 & 27 & 1.486 & 410 & 0 & $\mathrm{O} 3$ \\
\hline
\end{tabular}




\begin{tabular}{|c|c|c|c|c|c|c|c|c|c|c|c|c|c|c|c|c|c|c|c|}
\hline $\begin{array}{l}\text { Lutum } \\
(<2)\end{array}$ & $\begin{array}{l}\text { lutum } \\
\text { p10 }\end{array}$ & $\begin{array}{l}\text { Lutum_ } \\
\text { p90 }\end{array}$ & $\begin{array}{l}\text { Silt }(2- \\
50)\end{array}$ & $\begin{array}{l}\text { Leem } \\
(<50)\end{array}$ & $\begin{array}{l}\text { Leem_ } \\
\text { p10 }\end{array}$ & $\begin{array}{l}\text { Leem_ } \\
\text { p90 }\end{array}$ & $\begin{array}{l}\text { M5 } \\
0\end{array}$ & $\begin{array}{l}\text { M50_p } \\
10\end{array}$ & $\begin{array}{l}\text { M50_p } \\
90\end{array}$ & $\begin{array}{l}\mathrm{pH}- \\
\mathrm{KCl}\end{array}$ & $\begin{array}{l}\text { pH_p } \\
10\end{array}$ & $\begin{array}{l}\text { pH_p } \\
90\end{array}$ & $\begin{array}{l}\mathrm{CaC} \\
03\end{array}$ & $\begin{array}{l}\text { Fe_d } \\
\text { ith }\end{array}$ & $\begin{array}{l}\mathrm{C} / \\
\mathrm{N}\end{array}$ & $\begin{array}{l}\text { Dichth } \\
\text { eid }\end{array}$ & $\begin{array}{l}\text { Materi } \\
\text { aal }\end{array}$ & $\begin{array}{l}A=0 \\
\text { of } 1\end{array}$ & $\begin{array}{l}\text { Staring } \\
\text { bouwsteen }\end{array}$ \\
\hline 4 & 3 & 8 & 14 & 18 & 12 & 35 & $\begin{array}{r}15 \\
0 \\
15\end{array}$ & 130 & 170 & 4.4 & 3.9 & 5.0 & 0.0 & 0.2 & 27 & 1.574 & 410 & 0 & O3 \\
\hline 3 & 2 & 8 & 11 & 14 & 8 & 35 & 0 & 120 & 170 & 4.6 & 4.0 & 5.0 & 0.0 & 0.3 & 27 & 1.658 & 410 & 0 & O2 \\
\hline
\end{tabular}

$\begin{array}{rrrrrrrrrl}\begin{array}{c}\text { pH- } \\ \text { KCl }\end{array} & \text { pH_p10 } & \text { pH_p90 } & \text { CaC03 } & \text { Fe_dith } & \text { C/N } & \text { Dichtheid } & \text { Materiaal } & \begin{array}{l}\text { A=0 } \\ \text { of } 1\end{array} & \begin{array}{l}\text { Staring } \\ \text { bouwsteen }\end{array} \\ 5.2 & 4.5 & 5.5 & 0.0 & 0.2 & 17 & 1.384 & 410 & 1 & \text { B3 } \\ 4.5 & 4.2 & 5.0 & 0.0 & 0.2 & 25 & 1.494 & 410 & 0 & \text { O3 } \\ 4.6 & 4.2 & 5.0 & 0.0 & 0.2 & 25 & 1.607 & 410 & 0 & \text { O3 } \\ 4.6 & 4.0 & 5.0 & 0.0 & 0.3 & 25 & 1.658 & 410 & 0 & \text { O2 } \\ 5.0 & 4.5 & 5.5 & 0.0 & 0.2 & 17 & 1.349 & 410 & 1 & \text { B3 } \\ 4.5 & 4.2 & 5.0 & 0.0 & 0.2 & 25 & 1.494 & 410 & 0 & \text { O3 } \\ 4.6 & 4.2 & 5.0 & 0.0 & 0.2 & 25 & 1.607 & 410 & 0 & \text { O3 } \\ 4.6 & 4.0 & 5.0 & 0.0 & 0.3 & 25 & 1.658 & 410 & 0 & \text { O2 } \\ 3.9 & 3.4 & 4.2 & 0.0 & 0.2 & 23 & 1.31 & 410 & 1 & \text { B3 } \\ 4.0 & 3.7 & 4.5 & 0.0 & 0.2 & 27 & 1.486 & 410 & 0 & \text { O3 } \\ 4.4 & 3.9 & 5.0 & 0.0 & 0.2 & 27 & 1.574 & 410 & 0 & \text { O3 } \\ 4.6 & 4.0 & 5.0 & 0.0 & 0.3 & 27 & 1.658 & 410 & 0 & \text { O2 }\end{array}$

\section{Profiel boring 2}

Bovenkant Onderkant Staring bouwsteen

$\begin{array}{rrr}0 & 20 & \text { B3 } \\ 20 & 40 & \text { O3 } \\ 40 & 55 & \text { O3 } \\ 55 & 120 & \text { O2 } \\ 120 & 260 / 390 & \text { O6 } \\ 260 / 390 & 400 & \text { O5 }\end{array}$


Boring 3:

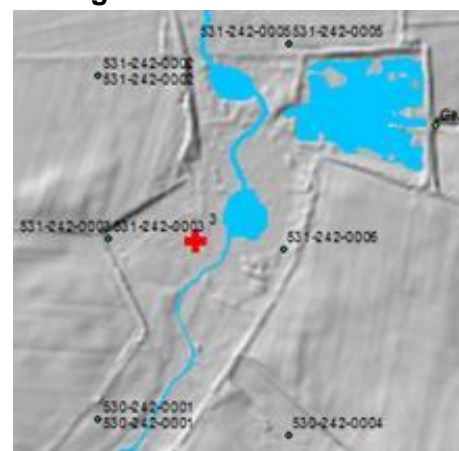

vW

Geen keileem

Boring:

531-242-0003

15.0 NAP

531-242-0005

14.7-14.7 m-NAP 1

14.2 - 14.0 m- NAP 3

$15.0-14.5 \mathrm{~m}$ - NAP

14.5-13.8 m- NAP 2

$14.0-12,81$ m- NAP 5

13.8-13.6 m- NAP 6

13.6-13.0 m- NAP 2

Wvp

\begin{tabular}{|c|c|}
\hline $531-242-0006$ & $531-242-0002$ \\
\hline $14.8 \mathrm{~m}+\mathrm{NAP}$ & $15.3 \mathrm{~m}+\mathrm{NAP}$ \\
\hline 14.8-14.5 m- NAP 1 & 15.3-14.9 m- NAP 1 \\
\hline 14.5-13.1 m- NAP 2 & 14.9-14.5 m- NAP 2 \\
\hline wvp & 14.5-14.4 m- NAP 1 \\
\hline & 14.4-13.27 m- NAP 3 \\
\hline
\end{tabular}

531-242-0006 531-242-0002

15.3-14.9 m- NAP

wvp

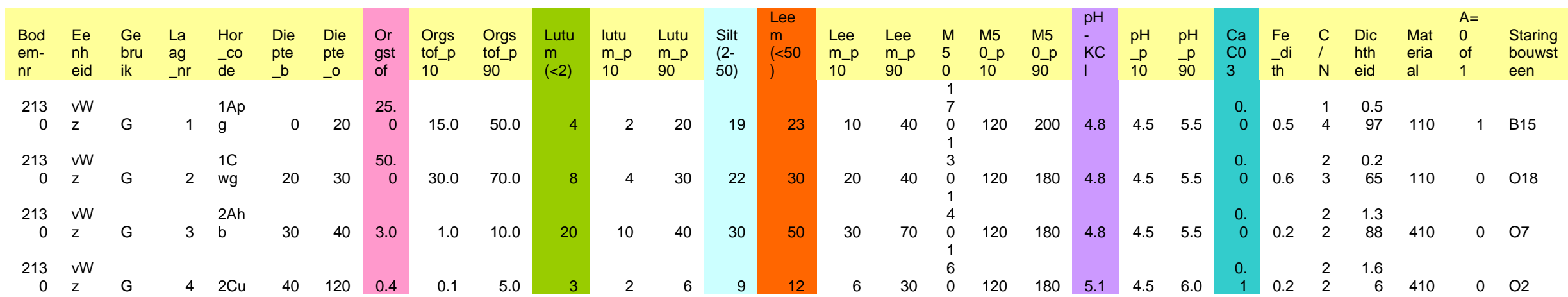

\begin{tabular}{|c|c|c|c|c|c|c|c|c|c|c|c|c|c|c|c|c|c|c|c|}
\hline $\begin{array}{l}\text { Lutum } \\
(<2)\end{array}$ & $\begin{array}{l}\text { lutum_ } \\
\text { p10 }\end{array}$ & $\begin{array}{l}\text { Lutum_ } \\
\text { p90 }\end{array}$ & $\begin{array}{l}\text { Silt (2- } \\
50)\end{array}$ & $\begin{array}{l}\text { Leem } \\
(<50)\end{array}$ & $\begin{array}{l}\text { Leem_ } \\
\text { p10 }\end{array}$ & $\begin{array}{l}\text { Leem_ } \\
\text { p90 }\end{array}$ & $\begin{array}{l}\text { M5 } \\
0\end{array}$ & $\begin{array}{l}\text { M50_p } \\
10\end{array}$ & $\begin{array}{l}\text { M50_p } \\
90\end{array}$ & $\begin{array}{l}\mathrm{pH}- \\
\mathrm{KCl}\end{array}$ & $\begin{array}{l}\mathrm{pH} \_\mathrm{p} \\
10\end{array}$ & $\begin{array}{l}\text { pH_p } \\
90\end{array}$ & $\begin{array}{l}\mathrm{CaC} \\
03\end{array}$ & $\begin{array}{l}\mathrm{Fe} \text {-d } \\
\text { ith }\end{array}$ & $\begin{array}{l}\mathrm{C} / \\
\mathrm{N}\end{array}$ & $\begin{array}{l}\text { Dichth } \\
\text { eid }\end{array}$ & $\begin{array}{l}\text { Materi } \\
\text { aal }\end{array}$ & $\begin{array}{l}A=0 \\
\text { of } 1\end{array}$ & $\begin{array}{l}\text { Staring } \\
\text { bouwsteen }\end{array}$ \\
\hline 4 & 2 & 20 & 19 & 23 & 10 & 40 & $\begin{array}{r}17 \\
0\end{array}$ & 120 & 200 & 4.8 & 4.5 & 5.5 & 0.0 & 0.5 & 14 & 0.597 & 110 & 1 & B15 \\
\hline
\end{tabular}




\begin{tabular}{|c|c|c|c|c|c|c|c|c|c|c|c|c|c|c|c|c|c|c|c|}
\hline $\begin{array}{l}\text { Lutum } \\
(<2)\end{array}$ & $\begin{array}{l}\text { lutum_ } \\
\text { p10 }\end{array}$ & $\begin{array}{l}\text { Lutum_ } \\
\text { p90 }\end{array}$ & $\begin{array}{l}\text { Silt (2- } \\
50)\end{array}$ & $\begin{array}{l}\text { Leem } \\
(<50)\end{array}$ & $\begin{array}{l}\text { Leem_ } \\
\text { p10 }\end{array}$ & & $\begin{array}{ll}\text { M5 } & \text { M } \\
0 & 10\end{array}$ & $\begin{array}{l}\text { M50_p } \\
10\end{array}$ & $\begin{array}{l}\text { M50_p } \\
90\end{array}$ & $\begin{array}{l}\mathrm{pH}- \\
\mathrm{KCl}\end{array}$ & $\begin{array}{l}\text { pH_p } \\
10\end{array}$ & $\begin{array}{l}\text { pH } \_p \\
90\end{array}$ & $\begin{array}{l}\mathrm{CaC} \\
03\end{array}$ & $\begin{array}{l}\text { Fe_d } \\
\text { ith }\end{array}$ & $\begin{array}{l}\mathrm{C} / \\
\mathrm{N}\end{array}$ & $\begin{array}{l}\text { Dichth } \\
\text { eid }\end{array}$ & $\begin{array}{l}\text { Materi } \\
\text { aal }\end{array}$ & $\begin{array}{l}A=0 \\
\text { of } 1\end{array}$ & $\begin{array}{l}\text { Staring } \\
\text { bouwsteen }\end{array}$ \\
\hline 8 & 4 & 30 & 22 & 30 & 20 & 40 & $\begin{array}{r}73 \\
0 \\
14\end{array}$ & 120 & 180 & 4.8 & 4.5 & 5.5 & 0.0 & 0.6 & 23 & 0.265 & 110 & 0 & 018 \\
\hline 20 & 10 & 40 & 30 & 50 & 30 & 70 & $\begin{array}{r}0 \\
16\end{array}$ & 120 & 180 & 4.8 & 4.5 & 5.5 & 0.0 & 0.2 & 22 & 1.388 & 410 & 0 & 07 \\
\hline 3 & 2 & 6 & 9 & 12 & 6 & 30 & 0 & 120 & 180 & 5.1 & 4.5 & 6.0 & 0.1 & 0.2 & 22 & 1.66 & 410 & 0 & $\mathrm{O} 2$ \\
\hline pH_p10 & pH_p90 & $\mathrm{CaC03}$ & Fe_dit & $\mathrm{C} / \mathrm{N}$ & Dichtheid & $\mathrm{Ma}$ & teriaal & $\begin{array}{l}A=0 \\
\text { of } 1\end{array}$ & $\begin{array}{l}\text { Staring } \\
\text { bouwst }\end{array}$ & teen & & & & & & & & & \\
\hline 4.5 & 5.5 & 0.0 & .0 & 14 & 0.597 & & 110 & 1 & B15 & & & & & & & & & & \\
\hline 4.5 & 5.5 & 0.0 & 0 & 23 & 0.265 & & 110 & 0 & O18 & & & & & & & & & & \\
\hline 4.5 & 5.5 & 0.0 & 0 & 22 & 1.388 & & 410 & 0 & $\mathrm{O} 7$ & & & & & & & & & & \\
\hline 4.5 & 6.0 & 0.1 & .1 & 22 & 1.66 & & 410 & 0 & $\mathrm{O} 2$ & & & & & & & & & & \\
\hline
\end{tabular}

\section{Profiel boring 3}

\begin{tabular}{rrll}
\hline Bovenkant & Onderkant & Staring bouwsteen & pZg23 \\
0 & 20 & B15 & \\
20 & 30 & O18 & \\
30 & 40 & O7 & \\
40 & 120 & O2 & \\
120 & 200 & O2 & fijn zand \\
200 & 400 & O5 & wvp
\end{tabular}

PS Gemiddelde dikte deklaag volgens boringen is $200 \mathrm{~cm}$

Omdat boring 3 en 5 leem bevat is vooral gekeken naar boring 6 en 5 , waarbij boring 5 nog een laagje veen bevat, voor de rest is de opbouw beneden de $120 \mathrm{~cm}$ fijn zand. 


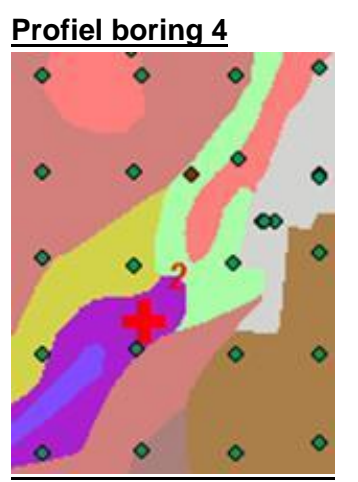

Bovenkant Onderkant Staring bouwsteen

$\begin{array}{rrll}0 & 20 & \text { B3 } & \\ 20 & 40 & \text { O3 } & \\ 40 & 55 & \text { O3 } & \\ 55 & 60 & \text { O2 } & \text { keileem } \\ 60 & 300 & \text { O6 } & \text { wvp } \\ 300 & 400 & \text { O5 } & \end{array}$

Slootdichtheid

\begin{tabular}{|l|l|l|l|l|}
\hline Locatie & 1 & 2 & 3 & 4 \\
\hline L_afwatering & 183 & 232 & 9058 & 3698 \\
\hline L_ontwatering & 115 & 125 & 77 & 130 \\
\hline L_totaal & 70 & 81 & 76 & 126 \\
\hline
\end{tabular}




\section{Bijlage 2 Achtergrond informatie moerasbossen}

\section{(Moeras-)bossen in de Landelijke Milieukartering}

In de landelijke milieukartering (Kalkhoven et al. 1979) werd gebruik gemaakt van de potentieel natuurlijke vegetatie (PVN). Een methode waarbij reeksen van vegetatietypen gekoppeld werden aan de PVN als 'eindstadium' van successie zonder menselijke beïnvloeding. Omdat de PVN afhankelijk is van de aanwezige milieuomstandigheden, vooral standplaatsfactoren klimaat (temperatuur, licht), water (grondwater, regenwater) en voedingsstoffen (incl. kalk), worden deze afgeleid van de bodem (bodemkaart waarin de grondwatertrappen zijn verwerkt). De PVN refereert overigens niet naar de climax toestand maar is in de tijd begrensd (50-150 jaar), eenmalig grote menselijke ingrepen worden meegenomen (bijvoorbeeld afgravingen) en exoten vormen onderdeel van nieuwe vegetaties (Kalkhoven et al. 1979).

De vegetatiereeksen zijn verzamelingen van vegetatietypen die als ontwikkelings-, vervangings- en begeleidende gemeenschappen onderling verbonden zijn. Kalkhoven et al. (1979) beschouwden 7 hoofdreeksen waarbinnen steeds 5 groepen zijn opgenomen langs de gradiënt niet tot sterk menselijk beïnvloed: bosvegetatie, struweelvegetatie, halfnatuurlijke landvegetatie, weinig of niet-natuurlijke landvegetatie en water- en moerasvegetatie. De hoogveen en duin hoofdreeksen wijken af maar zijn in deze studie niet relevant.

De groeiplaats van moeras- of broekbossen wordt gekenmerkt door een voor een groot deel van het jaar waterverzadigde bodem die leidt tot zuurstofloze omstandigheden. Er zijn slechts een paar boomsoorten die onder dergelijke omstandigheden kunnen overleven: zwarte els (Alnus glutinosa), zachte berk (Betula pubescens) en soms ook es (Fraxinus excelsior). Wordt de groeiplaats regelmatig overstroomd dan kan hier de wilg (Salix $s p$.) opslaan.

Voor de bosvegetatie in beekdalmoerassen neemt van der Werf (1991) in zijn indeling van Nederlandse bossen de groeiplaats als uitgangspunt die op termijn resulteert in een bepaalde vegetatie, de PVN. Het gaat er niet om wat op een bepaalde plaats groeit maar wat er zou kunnen groeien. Van der Werf (1991) plaatste de bossen in een ecogram (figuur B2.1). Het ecogram geeft een geleidelijke overgang van droge voedselarme omstandigheden in de linker bovenhoek naar natte voedselrijke omstandigheden in de rechterbenedenhoek weer. Moerasbossen staan onderin het figuur met wilgenbossen op de voedselrijkste groeiplaatsen die regelmatig overstroomd worden en waar ook afzetting van rijk sediment plaatsvindt en Berkenbroekbossen op de armste groeiplaatsen waar zure, basenarme omstandigheden heersen. De Elzenbroekbossen komen voor in een breed traject tussen voedselrijk en voedselarm met de associaties Kalkelzenbroek (Cirsio-Alnetum), Gewoon elzenbroek of Elzenzegge-elzenbroek (Carici elongatae-Alnetum), en Moerasvarenelzenbroek (Thelypterido-Alnetum) aan de voedselrijke en vooral Elzen-berkenbroek (AlnoBetuletum) en minder vaak Koningsvaren-elzenbroek (Carici laevigatae-Alnetum) aan de voedselarme kant. 


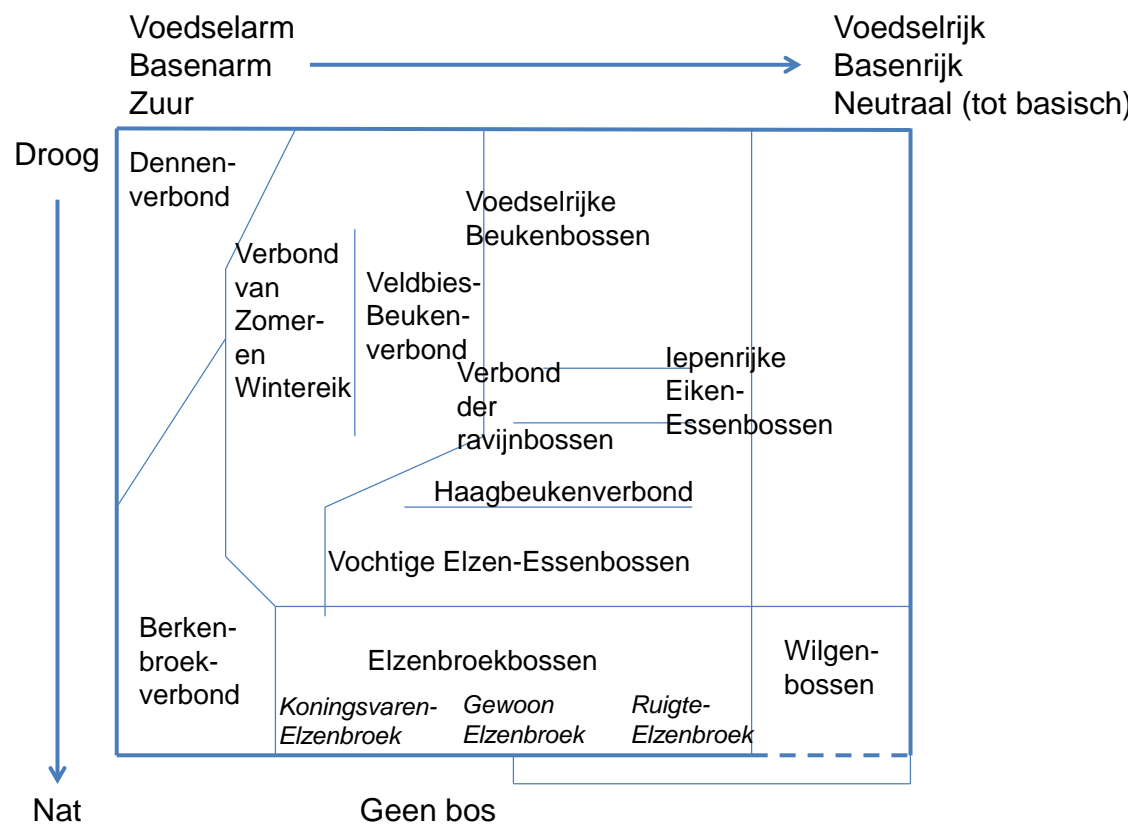

Figuur B2.1 Aangepast ecogram van klassen en verbonden (van der Werf 1991).

Van der Werf (1991) beschreef ook de groeiplaats van de verschillende bostypen (tabel B2.1). De voor het Geeserstroomdal relevante typen zijn er uitgelicht.

Tabel B2.1 Bosgemeenschappen die relevant kunnen zijn voor het Geeserstroomdal en de daarbij behorende groeiplaatsen (van der Werf 1991). [Vk = vochtklasse ( $D=d r o o g$, $V=$ vochtig, $Z V=z e e r$ vochtig, $N=$ nat), $G t=$ grondwatertrap (..e = extreme waterhuishouding (winter : nat; zomer: zeer droog), ..n = "nat" deel van de Gt, ..d = "droog" deel van de Gt)] (zie ook tabel 5.3).

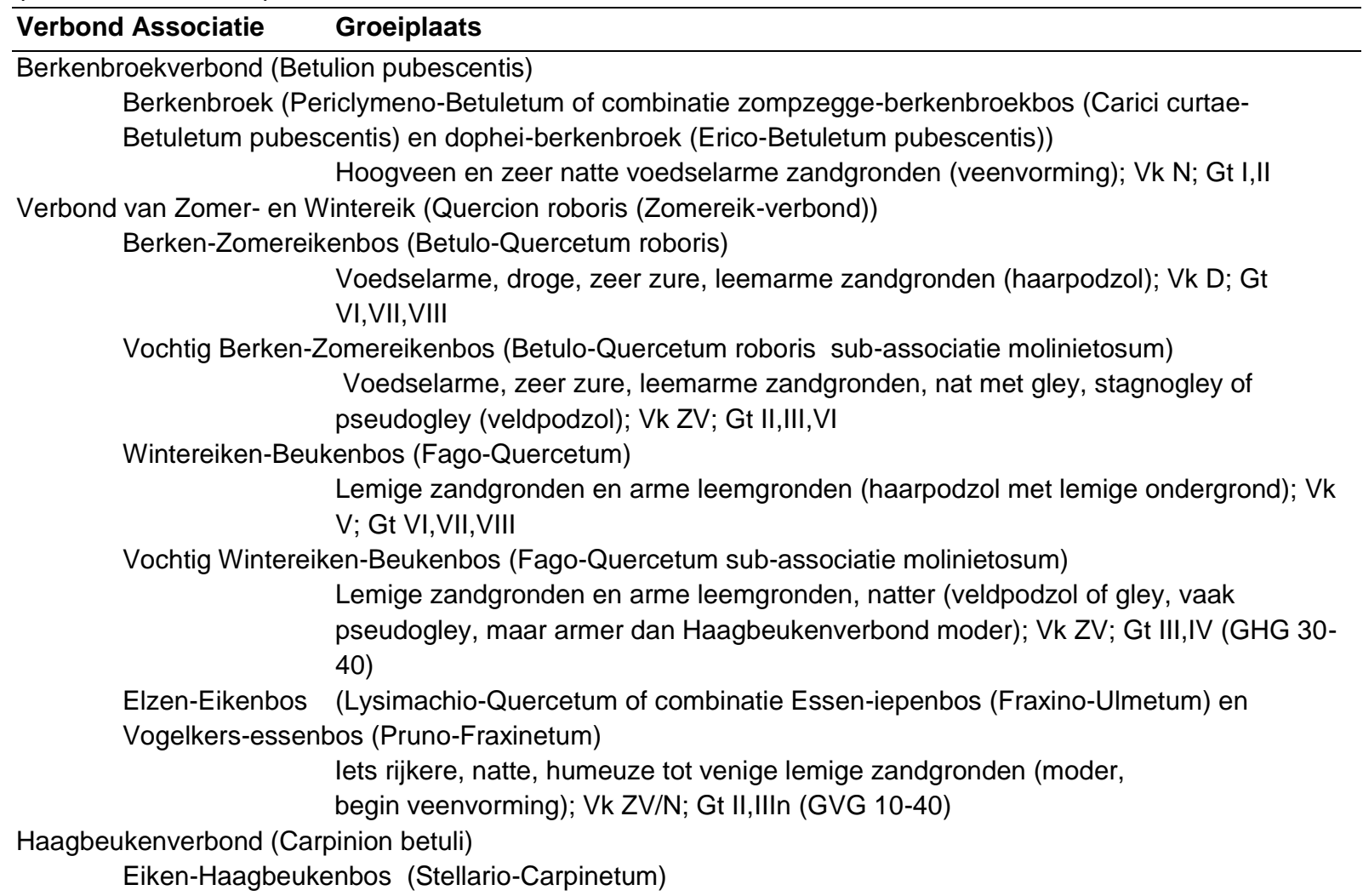


Pseudogley met basenrijke ondergrond op bijv . keileem, rivierleem, kleefaarde (pseudogley, muil); Vk ZV; Gt III,Ve

Arme variant van Eiken-Haagbeukenbos (Kamperfoelierijk) (Stellario-Carpinetum sub-associatie periclymenetosum

lemig zand op zure leem of klei (pseudogley, moder); Vk ZV; Gt III,Ve

Onderverbond van vochtige Elzen-Essenbossen / Els en Gewone vogelkers (Circaeo-Alnenion)

Vogelkers-Essenbos (Pruno-Fraxinetum)

Beekdalen met bewegend grondwater, relatief rijk, niet venig; Vk ZV/N; Gt II

Elzenverbond (Alnion glutinosae)

Gewoon Elzenbroek (Carici elongatae-Alnetum)

Matig basenrijke veengronden in zand- en in laagveengebieden met stagnerend water (veenvorming); Vk N; Gt I

Moerasvaren-Elzenbroek (Thelypterido-Alnetum)

Zeer nat laagveen met weinig veraarde bovenlaag (veenvorming); Vk N; Gt I

Elzen-Berkenbroek (Alno-Betulum)

Als Gewoon Elzenbroek en Elzen-Berkenbroek maar zuurder, stagnerender, iets

hoger (randgebieden). Ook geëutrofieerd hoogveen (zure veenvorming); Vk N; Gt I,I/II

Wilgenbroekstruwelen (Franguletea)

Wilgenverbond of verbond van de wilgenvloedbossen en -struwelen (Salicion albae) (Alleen rivierengebied)

Schietwilgen bos (Salicetum albae of combinatie van Bijvoet-ooibos (Artemisio-Salicetum albae), Lissen-

ooibos (Irido-Salicetum albae) en Veldkers-ooibos (Cardamino amarae-Salicetum albae))

Periodiek door rivierwater overstroomde dalen, voedselrijk (opslibbing), dynamisch

(rijping, humusvorming); Vk N; Gt 1,II,IIIn

\section{Beekdalbossen in Natuurkennis.nl}

Tenslotte vermeldt ook de OBN website Natuurklennis de voor beekdalen relevante bostypen (http://www.natuurkennis.nl/). 


\title{
Bijlage 3 Ondersteunde informatie bij hoofdstuk 2
}

\author{
Huidige toestand en processen beekdal Geeserstroom
}

\section{Systeemkenmerken en toestand voor de herinrichting}

\section{Geologie}

Het stroomgebied van de Geeserstroom is onderdeel van het noordelijk zandgebied (http://www.geologievannederland.nl/). Het gebied is gevormd tijdens het Elsterien (rond 425.000 jaar geleden) en het Saalien (rond 200.000 jaar geleden) en is een vrij zwak glooiend met keileem en dekzand aan het oppervlak. Dergelijke gebieden met keileem aan het oppervlak hebben vaak een beperkte afwatering. In de diepere ondergrond bevinden zich rivierafzettingen die tijdens de ijstijden zijn opgestuwd en over elkaar geschoven. Door de gletsjers is vermalen gletsjerpuin afgezet; de keileem. Daarnaast hebben de gletsjers ook grove zanden en grinden afgezet. Bij het terugtrekken van de gletsjers ontstonden smeltwatermeren waarin zeer fijne klei werd afgezet (bijvoorbeeld de potklei van het Drents plateau). Na de ijstijden werd tijdens de koude periode veel zand uitgeblazen van de bodem van de toen opgedroogde Noordzee, de beddingen van rivieren en de lokale hoogtes. Dit zand bedekte de door het ijs gevormde landschapsglooiingen (http://www.geologievannederland.nl/).

\section{Bodemopbouw}

De bodem in het Geeserstroomdal bestaat in hoofdzaak uit veengrond, moerige grond, en veel beekeerdgrond (figuur B3.1). Grote oppervlakten veen (meestal geen dikke pakketten) zijn aanwezig in de Mepper Hooilanden en in het zuiden van het stroomgebied. In de veengronden is vaak ook beekleem aanwezig. Het beekdal is veelal ijzerrijk, soms met ijzeroer. Op de hogere gronden overheersen de veldpodzolen. Dieper in de bodem bevinden zich in bijna het gehele stroomgebied slecht doorlatende lagen van kei- en beekleem (dikte 0.2-3.0 m). Het keileem ontbreekt waarschijnlijk in de Mepper Hooilanden en de Marsen en in een groot deel van het zuidelijke veengebied (Werkgroep Geeserstroom 2004, Didderen et al. 2009). 

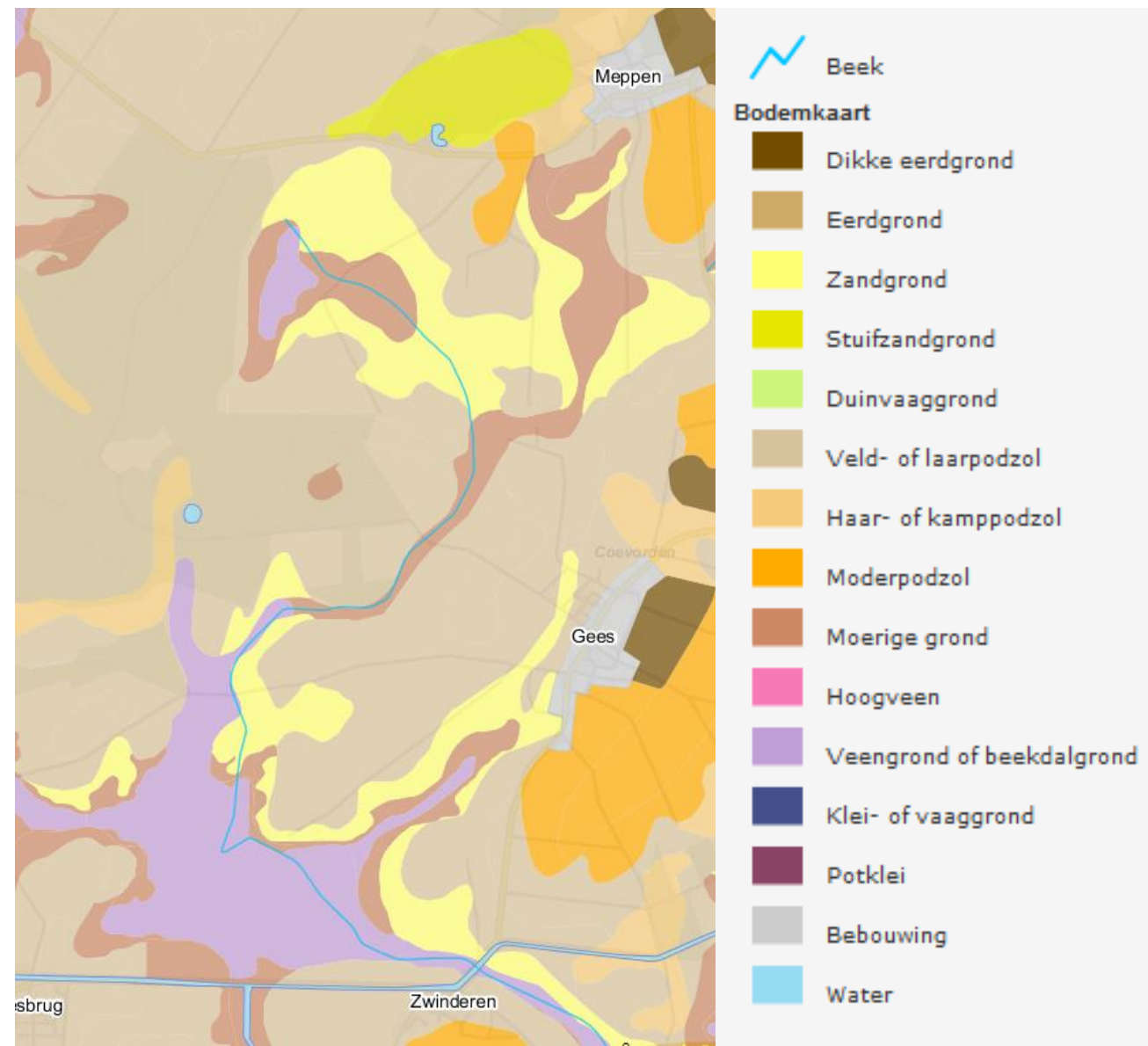

Figuur B3.1 Vereenvoudigde bodemkaart van het stroomgebied Geeserstroom (http://www.drenthe.info/website/bodematlas/).

\section{Historische ontwikkelingen}

Met de komst van mensen verdwenen langzaam de bossen door begrazing door vee en het kappen van bomen. In het beekdal ontstonden op de rijkere gronden weidegronden en op de hogere gronden ontstonden, mede door het steken van plaggen, heidegronden (Didderen et al. 2009 uit Schimmel et al. 1995). Op de kaart van 1665 is goed te zien (figuur B3.2a) dat ten oosten en ook in het zuidwesten van de Geeserstroom zich een groot hoogveen (Groote Veenen) uitstrekt die de beek richting Coevorden dwingt.

Ook in de periode 1773-1794 waren in het stroomgebied van de Geeserstroom nog grote oppervlaktes niet in cultuur gebrachte grond aanwezig (figuur B3.2a,b,c). Een groot deel van de bossen zijn verdwenen en een onderscheid in hoogveen en heide wordt niet meer gemaakt.

De heiden waren waarschijnlijk gemeenschappelijke weidegronden. Hooilanden lagen in een aantal dalfragmenten; het noordelijke deel van de Mepper Hooilanden, de Zuidmaten, de Bollema, een smalle zone ten zuiden van de Tilweg over de Geeserstroom en een smalle zone langs de Klinkenberg, doorlopend tot Zwinderen.

De afwatering begon ten noordoosten van het Mepperzand bij een meer. De beekvorm was licht kronkelig tot de huidige Tilweg en vanaf de Tilweg begon de beek sterker te meanderen. Midden in het dal van de Oude Maden was geen watergang getekend. De Verlengde Hoogeveense Vaart bestond nog niet (Werkgroep Geeserstroom 2004).

Rond 1850 zijn de velden Koematen en de Marsen ontgonnen en is rond de Bergstukken het graslandgedeelte veel breder geworden. Rond deze tijd is ook een tweede waterloopje 
zichtbaar in de Bergstukken. De Verlengde Hoogeveense Vaart is al aangelegd, de Geeserstroom waterde toen nog niet af op de vaart, maar kwam uit in het Loodiep. De Roonboomdijk lijkt aanwezig, dit mogelijk ter voorkoming van afstroom van zuur (veen)water naar de graslanden.

De topografische kaart van 1925 laat zien dat het voormalige hoogveen al geheel is ontgonnen en in cultuur gebracht is (figuur 2.4c). Een nieuw element is de aanwezigheid van aangeplante dennenbossen op de voormalige heidevelden.

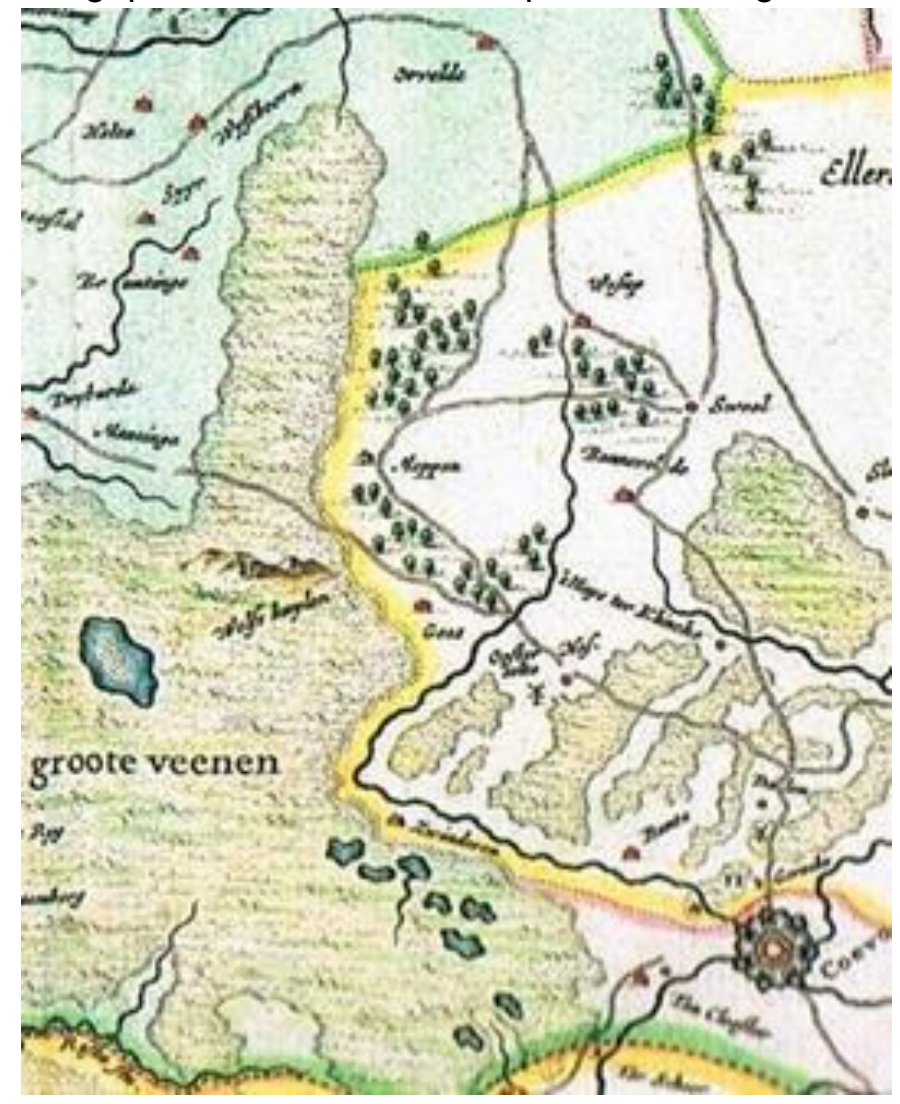

Figuur B3.2a Kaart van 1665 met daarop de nog intakte hoogveenlob (Grooote Veenen) ten westen en zuidwesten van het gebied van de Geeserstroom.

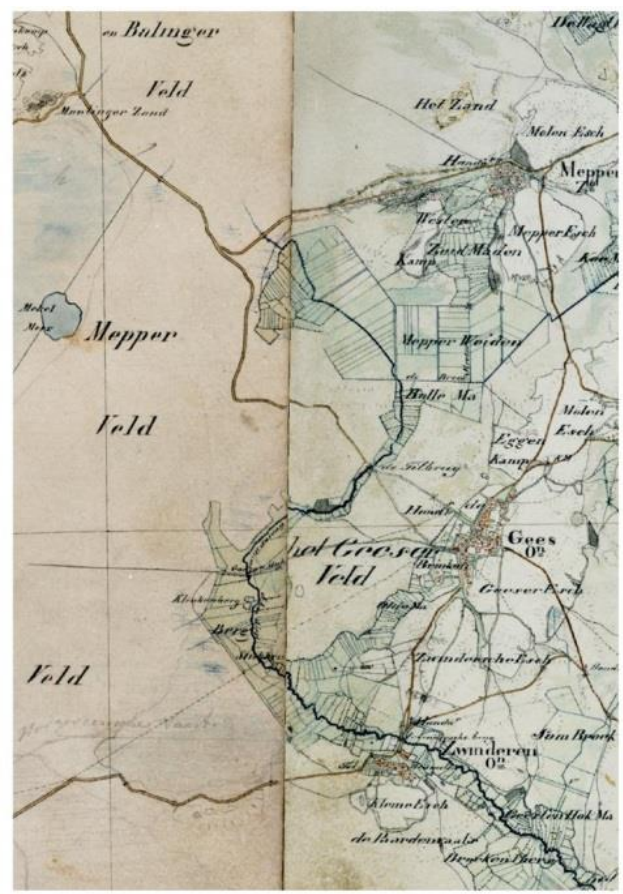




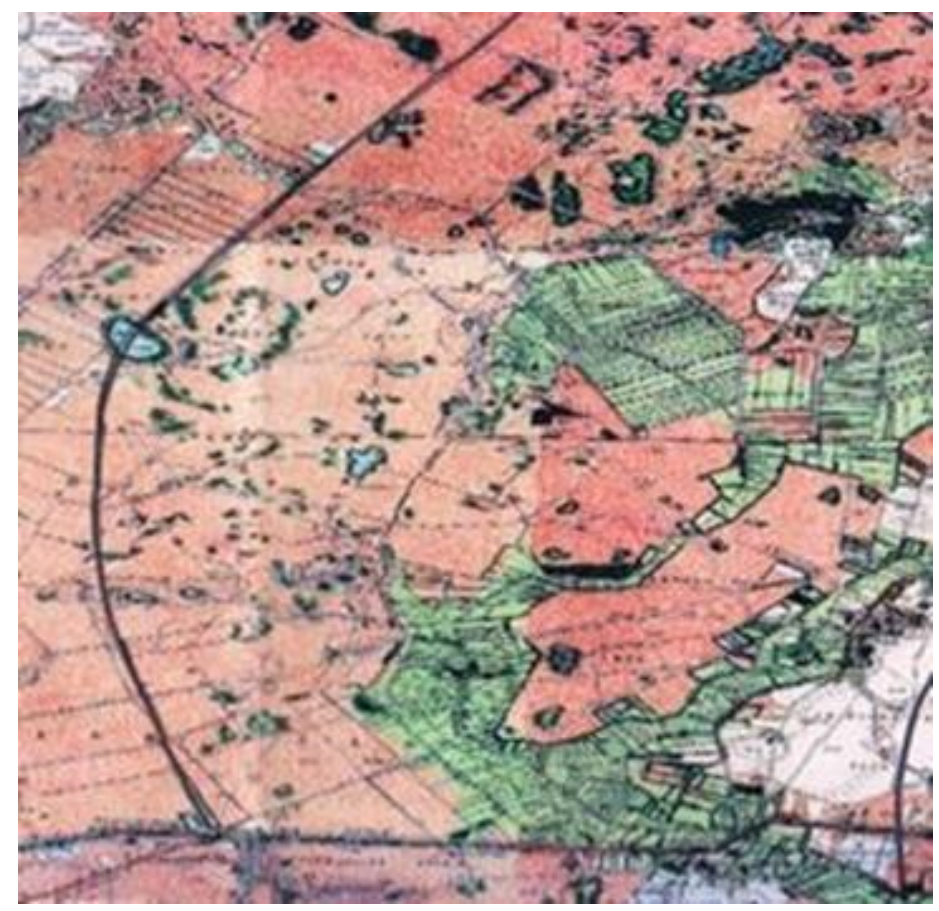

Figuur B3.2b Historische kaart van de Geeserstroom. Links: militaire stafkaarten uit 1895 in de Hottings Atlas (1785) en rechts: historische kaart van 1900 (let op: in het noordwesten is te zien dat in deze periode het hoogveen wordt gedraineerd en geëxploiteerd).

Op de kaarten van 1773-1794 is niet duidelijk aangegeven of er in en rond een deel van de hooilanden houtige begroeiingen aanwezig zijn. Op de kaart van 1900 zijn voor het eerst echt duidelijk structuren van houtwallen en -singels te zien. Mogelijk zijn deze voornamelijk aangelegd na de markenscheidingen.

Vanaf 1900 hebben meer ingrijpende handelingen de omgeving van het beekdal veranderd. Tussen 1900 en 1923 is de hoofdgeul van de Geeserstroom gekanaliseerd en vond de afwatering plaats op de Verlengde Hoogeveense Vaart, zelfs met stuwen. Het Loodiep bleef nog onaangetast. 


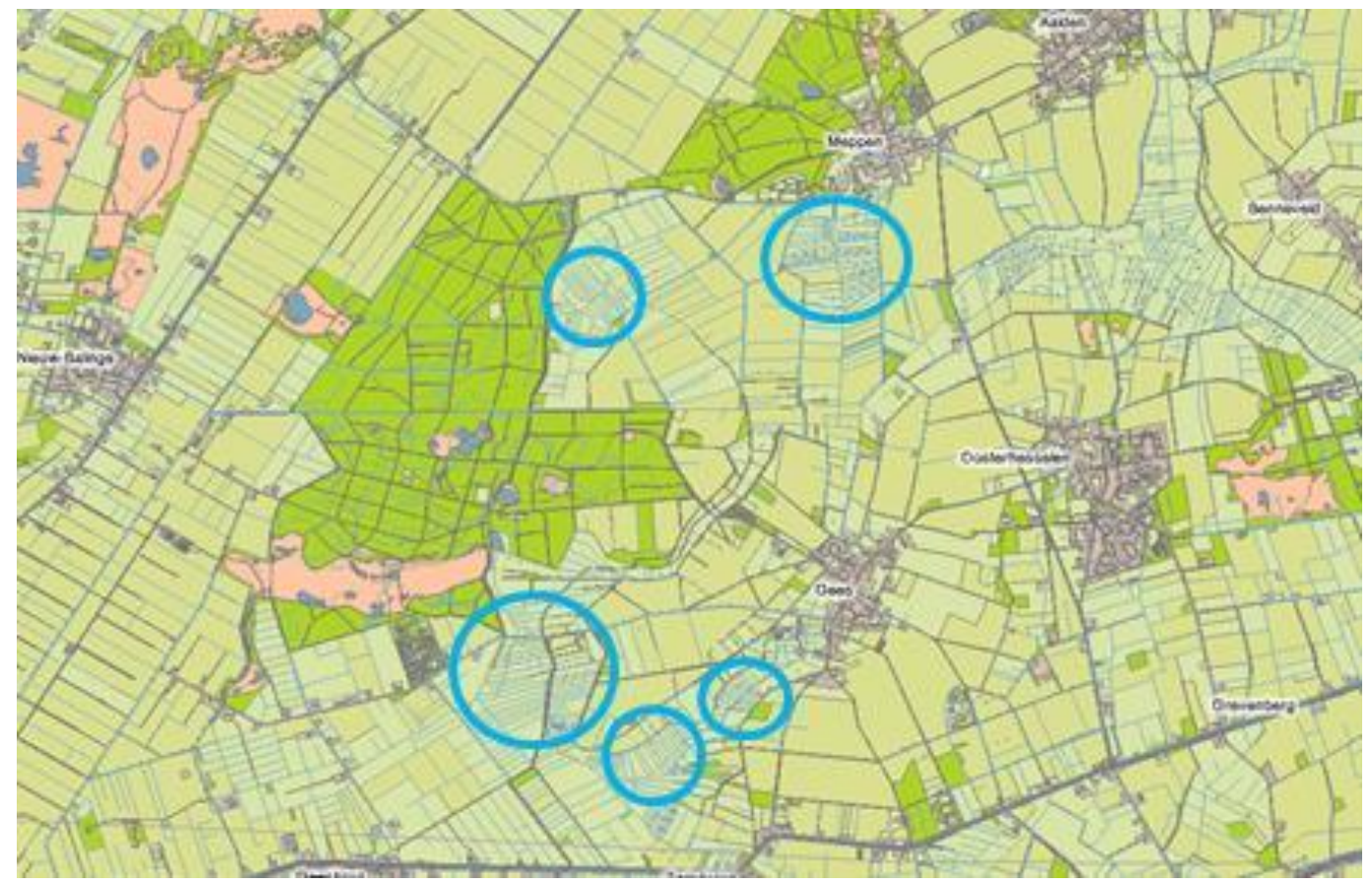

Figuur B3.2c De topografische kaart van 1925. De blauwe circels geven gebieden aan met een dicht slotenpatroon, die duiden op het voorkomen van sterke kwel in de graslanden.

De kaarten van 1950/1952 laten een sterke inkrimping van het areaal heide zien ten opzichte van 1900. In 1955 is door Staatsbosbeheer onderzoek (Schimmel et al. 1995) gedaan naar het Loodiep. De beek had een pH van 5.4 en er werd alleen een begeleidende soort voor langzaam stromende benedenlopen Platycnemis pennipes aangetroffen. Op de kaart uit 1962 is nog minder heide aanwezig en zelfs de tot dan toe overgebleven veentjes zijn ontgonnen. De dwarswalletjes tussen de rand van de Koematen en De Marsen zijn verdwenen. Het Loodiep is nog steeds niet rechtgetrokken. In 1972 is het Loodiep rechtgetrokken. Ook is er een nieuwe watergang gegraven midden door de Oude maten en de Rotten, het stroompje uit Gees. De beekdalrandbeplanting langs de rand van de Koematen en Marsen is grotendeels verdwenen.

In de directe oeverbegroeiing van Drentse beken rond 1955 werd onder andere nog goudveil, bronkruid en bittere veldkers gevonden. In de oorspronkelijk niet bemeste hooilanden stonden nog orchideeën, parnassia en adderwortel (Schimmel et al. 1995). Er waren twee rioolwater overstorten in het gebied, bij Meppen en bij Gees. Het stroomgebied van de Geeserstroom was voor de herinrichting ingericht voor de landbouwfunctie (figuur 2.1). De percelen waren goed ontwaterd en de beek was rechtgetrokken, deels van kades voorzien en stroomde af in de Verlengde Hoogeveense Vaart. De koppeling met het Loodiep, de oorspronkelijke middenloop van de beek, ontbrak.

\section{Kwel en vegetatie voor de ingreep}



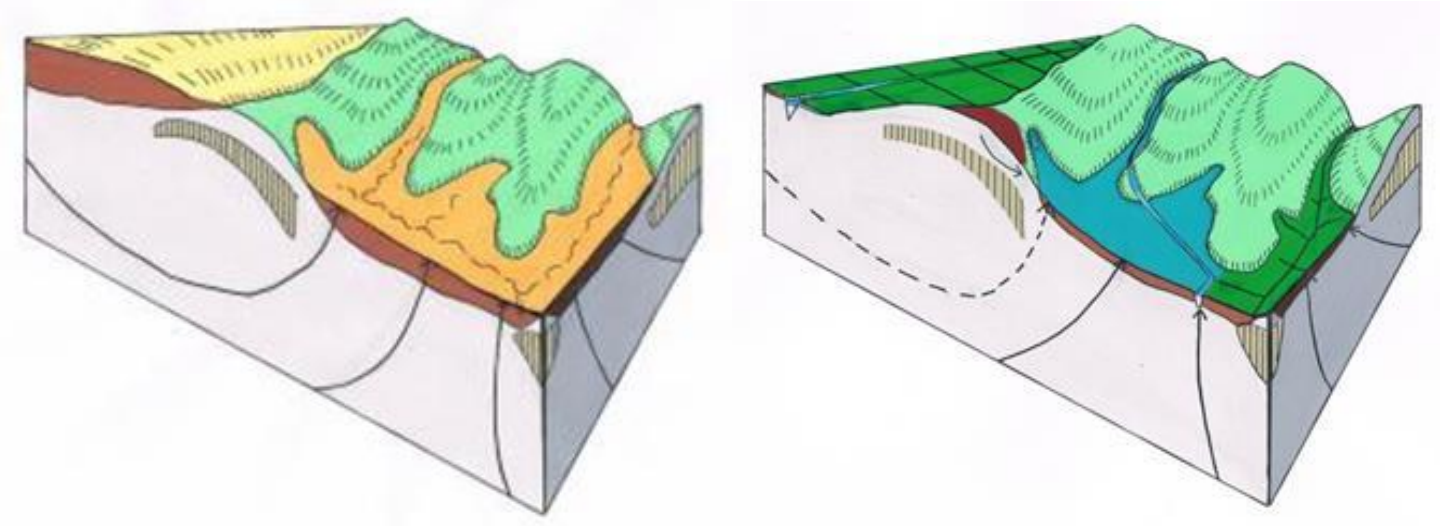

Figuur B3.3 Mogelijke veranderingen in het hydrologische systeem in het gebied rond de Bergstukken en Roonboom (het zuidelijk deel van het onderzoeksgebied), met links de situatie zonder menselijke ingrepen en recht de huidige situatie. Geel is het voormalige hoogveen in het westen. Oranje is levend laagveen. Dit grondwater-gevoede veenpakket ligt in de beekdalen en is veel dikker dan tegenwoordig. Lichtgroen zijn de minerale gronden met daaronder nog restanten van keileem. In het beekdal zelf is de keileem in het verleden weg geërodeerd.

Figuur B3.3 geeft de mogelijke veranderingen weer in het hydrologische systeem als gevolg van het menselijk gebruik van het landschap. Vooral het afgraven en draineren van de voormalige hoogveengebieden heeft geleid tot het verminderen van de kweldruk in het beekdal. De drainage in het beekdal zelf (ten behoeve van de landbouw) heeft geleidt tot sterke zakking van de veenpakketten.

Voor de hydrologische herstelmaatregelen in het beekdal gaf de verspreiding van moeras en hooilandsoorten nog steeds aan dat basenrijke kwel in het beekdal nog aanwezig was.

De vegetatie in het bovenstrooms deel, de Mepper Hooilanden, Koemarsen, en de Marsen bevatte bijvoorbeeld veel soorten van matig hard water zoals moeraszegge, dotterbloem en holpijp, maar ook soorten van minder hard water zoals snavelzegge, moerasviooltje en zompzegge (Didderen et al. 2009). Op grond van het voorkomen van deze indicator soorten werd geconcludeerd dat in dit deelgebied sprake moest zijn van zowel kwelinvloeden uit (sub)regionale als lokale systemen. De lokale kwel zou dan afkomstig zijn uit de Boswachterij Gees en het Dennekamp. In de velden waarin de middelloop van de Geeserstroom ligt zijn plekken zonder keileem. Hier werden plantensoorten (beekpunge, moeraszegge en waterviolier) aangetroffen die (sub)regionale en lokale kwel indiceren in de sloten rondom de Geeserstroom. In de benedenloop in het dal ter hoogte van de Klinkerberg was aan de westrand een gradiënt in kwelwater te vinden, van vrij zuur (met dophei en tormentil) naar zacht (met sterzegge, geelgroene zegge en waterviolier) tot matig hard water (met dotterbloem en waterkruiskruid). Het zachte water kwam waarschijnlijk van de flanken, over het keileem. Het matig harde water was mogelijk afkomstig uit het tweede watervoerende pakket komen. In het meer stroomafwaarts gelegen brede en open beekdal waren geen duidelijke invloeden van kwel zichtbaar (Werkgroep Geeserstroom 2004). Het stroompje uit Gees ontving in het bovenstroomse deel, de Oude Maden, voornamelijk toevoer van lokale kwel, met bronkruid, zeegroene muur en veldrus. Op een gering aantal plekken indiceerden dotterbloem en waterkruiskruid kwel van matig hard grondwater. In het benedenstroomse deel, de Rotten en Luibroekma, kleurde het water in de sloten rood (ijzerrijk kwelwater). Hier werden ook dotterbloem en holpijp aangetroffen, kwelindicatoren 
van matig hard water. Langs de randen van het gebied kwam ook water voor dat meer een lokale herkomst had (Werkgroep Geeserstroom 2004).

Uiterlijk was voor de herinrichting de landschapsstructuur van een beekdal rond 1900 nog steeds herkenbaar door het voorkomen van vele houtsingels en -wallen en benedenstrooms een beekdal met een open karakter. De slechte structuur van de houtsingels en -wallen zorgde er wel voor dat deze landschappelijk in een slechte toestand verkeren, dit kwam door het ontbreken van dichte struikvegetaties. In het benedenstroomse beekdal was het open karakter al aangetast door aanplantingen uit de jaren '70. Het beekdal miste ook de verlandingsvegetaties in de laagste delen van het dal en de overgangen van natte tot vochtige schraallanden naar heide en bos (Werkgroep Geeserstroom 2004).

\section{Aquatich-ecologische toestand voor de ingreep}

In het rapport Ecologische doelstellingen en beoordelingsmethode voor stromende wateren (Torenbeek \& Gijsen 1990) is de Geeserstroom ingedeeld bij het type slootbeken. Binnen dit type had een Geeserstroom een goede kwaliteit zowel in het voorjaar als najaar van 1984 en 1985. De Geeserstroom had in de periode 1991-1997 een natuurfunctie op middenniveau. Op dit niveau moet het ecosysteem zich in een goede staat bevinden, lozingen mogen geen overwegende invloed hebben op het systeem en de inrichting van de waterloop moet mede zijn afgestemd op het ecosysteem. De natuurwaarde van de Geeserstroom was redelijk (10 doelsoorten), echter bij een goede natuurwaardering zouden ten minste 20 doelsoorten aanwezig moeten zijn (Duursema en Torenbeek 1997). In 2002 zijn ten behoeve van het herinrichtingsplan op vier punten macrofauna monsters genomen. Het monsterpunt bij de Koemaatsendijk en het monsterpunt in het Loodiep hadden een geringe natuurwaarde, met in De Marsen veel slib gebonden fauna. De monsters bij de Tilbrug en in de Bergstukken hebben een matige kwaliteit, met in de Bergstukken onder andere veel steenvliegen (Werkgroep Geeserstroom 2004).

Uit onderzoek naar nutriënten in het oppervlaktewater had het watersysteem van het Loo- en Drostendiep ten zuiden van de Verlengde Hoogeveense Vaart een enigszins slechtere kwaliteit dan die in het noorden, onder andere in de Geeserstroom. Dit komt vooral in het ortho-fosfaat- en ammoniumgehalte tot uitdrukking. Het nitraatgehalte is in het hele gebied in de winter vaak verhoogd (Torenbeek 1999).

\section{Vogels}

In 2015 is een vogelinventarisatie uitgevoerd (tabel B3.1) en zijn de territoria geteld. Het gebied is hiervoor in drie deelgebieden verdeeld:
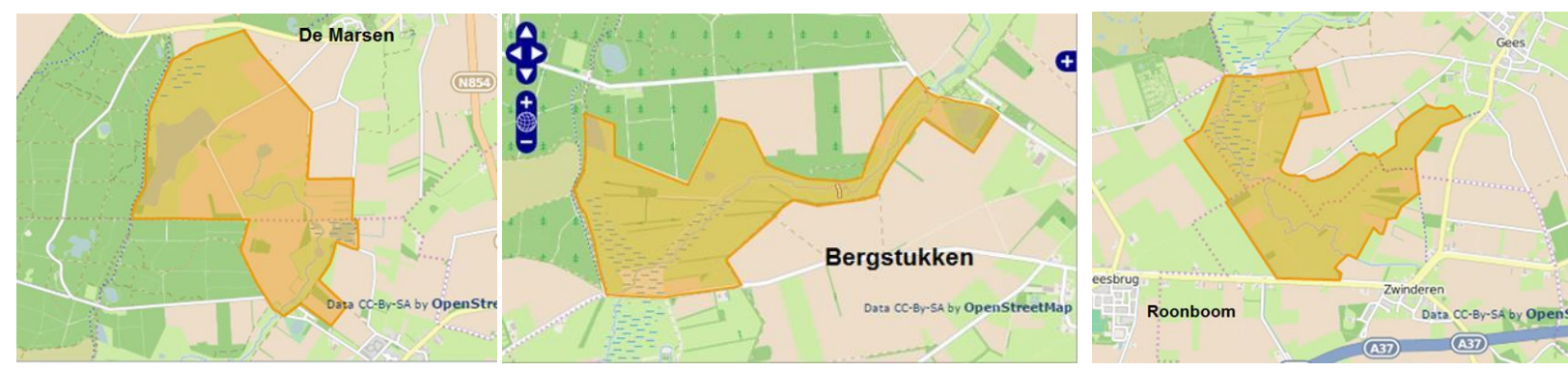

Tabel B3.1. Aantal broedparen in de Geeserstroom (Arend J. van Dijk en Joop Kleine, Drentse vogels 29, 2015).

\begin{tabular}{|l|l|l|l|l|l|}
\hline Telling 22 mei 2015 & De Marsen & Bergstukken & Roonboom & Totaal & $\begin{array}{l}\text { Aantal } \\
\text { territoria }\end{array}$ \\
\hline
\end{tabular}




\begin{tabular}{|c|c|c|c|c|c|}
\hline Appelvink & 2 & 0 & 3 & 5 & 8 \\
\hline Bergeend & 1 & 0 & 0 & 1 & 1 \\
\hline Blauwborst & 16 & 2 & 19 & 37 & 39 \\
\hline Bonte Vliegenvanger & 3 & 0 & 3 & 6 & 7 \\
\hline Boomklever & 3 & 2 & 3 & 8 & 10 \\
\hline Boomkruiper & 11 & 9 & 26 & 46 & 56 \\
\hline Boomleeuwerik & 1 & 0 & 0 & 1 & 2 \\
\hline Boompieper & 19 & 13 & 27 & 59 & 63 \\
\hline Bosrietzanger & 1 & 0 & 11 & 12 & 67 \\
\hline Braamsluiper & 2 & 0 & 0 & 2 & 2 \\
\hline Buizerd & 1 & 0 & 4 & 5 & 8 \\
\hline Bruine kiekendief & & & & & 1 \\
\hline Canadese gans & & & & & 4 \\
\hline Dodaars & 2 & 2 & 3 & 7 & 7 \\
\hline Draaihals & 0 & 0 & 1 & 1 & 1 \\
\hline Fazant & 2 & 0 & 6 & 8 & 9 \\
\hline Fitis & 45 & 10 & 38 & 93 & 117 \\
\hline Fluiter & 1 & 0 & 0 & 1 & 1 \\
\hline Fuut & 6 & 0 & 0 & 6 & 7 \\
\hline Gaai & 2 & 2 & 8 & 12 & 14 \\
\hline Geelgors & 20 & 11 & 22 & 53 & 65 \\
\hline Gekraagde Roodstaart & 5 & 8 & 12 & 25 & 35 \\
\hline Gele Kwikstaart & 13 & 5 & 5 & 23 & 25 \\
\hline Geoorde fuut & 2 & 0 & 0 & 2 & 2 \\
\hline Glanskop & 1 & 0 & 0 & 1 & 1 \\
\hline Goudhaan & 5 & 0 & 0 & 5 & 6 \\
\hline Goudvink & 1 & 0 & 1 & 2 & 6 \\
\hline Grasmus & 49 & 15 & 72 & 136 & 155 \\
\hline Graspieper & 36 & 0 & 6 & 42 & 42 \\
\hline Grauwe Gans & 26 & 24 & 26 & 76 & 76 \\
\hline Grauwe Klauwier & 0 & 0 & 3 & 3 & 6 \\
\hline Grauwe Vliegenvanger & 2 & 0 & 5 & 7 & 14 \\
\hline Groene Specht & 1 & 1 & 3 & 5 & 5 \\
\hline Groenling & 3 & 0 & 2 & 5 & 4 \\
\hline Grote Bonte Specht & 6 & 5 & 8 & 19 & 21 \\
\hline Grote Canadese Gans & 4 & 1 & 1 & 6 & 2 \\
\hline Grote Lijster & 2 & 1 & 1 & 4 & 4 \\
\hline Heggenmus & 7 & 1 & 7 & 15 & 22 \\
\hline Holenduif & 1 & 3 & 3 & 7 & 10 \\
\hline Houtduif & 7 & 1 & 14 & 22 & 30 \\
\hline Houtsnip & 1 & 0 & 0 & 1 & 1 \\
\hline Huismus & & & & & 3 \\
\hline Kievit & 3 & 4 & 0 & 7 & 9 \\
\hline Kleine Bonte Specht & 5 & 1 & 4 & 10 & 12 \\
\hline Kleine Karekiet & 15 & 7 & 30 & 52 & 81 \\
\hline
\end{tabular}




\begin{tabular}{|c|c|c|c|c|c|}
\hline Kleine Plevier & 1 & 0 & 1 & 2 & 3 \\
\hline Kneu & 9 & 2 & 5 & 16 & 19 \\
\hline Knobbelzwaan & 4 & 3 & 3 & 10 & 10 \\
\hline Koekoek & 4 & 2 & 4 & 10 & 10 \\
\hline Koolmees & 23 & 13 & 31 & 67 & 77 \\
\hline Krakeend & 10 & 2 & 11 & 23 & 23 \\
\hline Kuifeend & 18 & 5 & 4 & 27 & 28 \\
\hline Kwartel & & & & & 3 \\
\hline Matkop & 3 & 1 & 4 & 8 & 11 \\
\hline Meerkoet & 69 & 23 & 48 & 140 & 150 \\
\hline Merel & 35 & 14 & 71 & 120 & 153 \\
\hline Nijlgans & 8 & 2 & 6 & 16 & 19 \\
\hline Ooievaar & 0 & 0 & 2 & 2 & 2 \\
\hline Paapje & 0 & 0 & 2 & 2 & 2 \\
\hline Pimpelmees & 24 & 14 & 46 & 84 & 97 \\
\hline Porseleinhoen & 7 & 0 & 8 & 15 & 15 \\
\hline Putter & 10 & 1 & 2 & 13 & 19 \\
\hline Rietgors & 60 & 14 & 70 & 144 & 150 \\
\hline Rietzanger & 8 & 0 & 16 & 24 & 29 \\
\hline Ringmus & & & & & 1 \\
\hline Roerdomp & 3 & 3 & 4 & 10 & 10 \\
\hline Roodborst & 23 & 7 & 27 & 57 & 62 \\
\hline Roodborsttapuit & 7 & 1 & 17 & 25 & 32 \\
\hline Scholekster & 1 & 1 & 0 & 2 & 2 \\
\hline Slobeend & 10 & 0 & 6 & 16 & 16 \\
\hline Snor & 2 & 0 & 2 & 4 & 6 \\
\hline Soepeend & & & & & 1 \\
\hline Spotvogel & 1 & 0 & 7 & 8 & 13 \\
\hline Spreeuw & 8 & 14 & 24 & 46 & 54 \\
\hline Sprinkhaanzanger & 11 & 1 & 14 & 26 & 36 \\
\hline Staartmees & 5 & 1 & 3 & 9 & 17 \\
\hline Tafeleend & 1 & 0 & 0 & 1 & 3 \\
\hline Tjiftjaf & 32 & 11 & 64 & 107 & 120 \\
\hline Tuinfluiter & 19 & 4 & 35 & 58 & 93 \\
\hline Tureluur & 2 & 1 & 0 & 3 & 3 \\
\hline Veldleeuwerik & 19 & 0 & 0 & 19 & 20 \\
\hline Vink & 31 & 15 & 40 & 86 & 107 \\
\hline Waterhoen & 30 & 4 & 25 & 59 & 63 \\
\hline Waterral & 23 & 2 & 30 & 55 & 61 \\
\hline Watersnip & 5 & 0 & 11 & 16 & 18 \\
\hline Wielewaal & 1 & 1 & 2 & 4 & 6 \\
\hline Wilde Eend & 62 & 29 & 83 & 174 & 179 \\
\hline Winterkoning & 23 & 3 & 34 & 60 & 66 \\
\hline Wintertaling & 8 & 2 & 2 & 12 & 15 \\
\hline Witte Kwikstaart & 7 & 6 & 4 & 17 & 20 \\
\hline
\end{tabular}




\begin{tabular}{|l|c|c|c|c|c|} 
Wulp & 2 & 0 & 0 & 2 & 2 \\
\hline IJsvogel & & & & & 2 \\
\hline Zanglijster & 8 & 3 & 19 & 30 & 34 \\
\hline Zomertaling & 6 & 3 & 10 & 19 & 19 \\
\hline Zwarte Kraai & 5 & 1 & 8 & 14 & 14 \\
\hline Zwarte mees & 1 & 0 & 0 & 1 & 1 \\
\hline Zwartkop & 23 & 11 & 45 & 79 & 101 \\
\hline
\end{tabular}




\section{Bijlage 4 Ondersteunde informatie bij hoofdstuk 4}

\section{Sleutelfactoren in broekbossen}

\section{Microklimaat}

In de zomer heerst in een broekbos een uitgesproken koel en vochtig microklimaat (Darell \& Cronberg 2011). Het bladerdak zorgt ervoor dat er in de zomer weinig licht tot op de bosbodem doordringt en de verdamping geremd wordt, wat nog verder versterkt kan worden door de vegetatiestructuur van de kruidlaag. Dit heeft tot gevolg dat de (water) temperatuur in het broekbos en tussen het strooisel gedempt de fluctuaties buiten het bos volgt, met relatief hoge minimumtemperaturen en lage maximumtemperaturen. Verder is de luchtvochtigheid continu hoog omdat de grondwaterspiegel niet ver onder het maaiveld ligt en windwerking weinig effect heeft tussen de vegetatie (Runhaar et al. 2013). Veel hygrofiele (semi-)terrestrische bossoorten (o.a. loopkevers) maar ook aquatische ongewervelden zoals de schaatsenrijder Gerris lateralis zijn gebonden aan deze combinatie van weinig licht, een hoge bodem- en luchtvochtigheid en een relatief lage temperatuur, welke vaak noodzakelijk is voor de ontwikkeling tot volwassen dier (Turin 2000; Aukema 2002; Lambeets et al 2009).

Voor de aquatische organismen is dit specifieke microklimaat minder belangrijk, omdat deze soorten zich meestal ontwikkelen op het moment dat er geen of weinig blad aan de bomen zit. Toch is de watertemperatuur van groot belang. Aangezien bij de meeste aquatische organismen alleen groei optreedt boven een bepaalde watertemperatuur, is met name het voorjaar geschikt als ontwikkelingsperiode, simpelweg omdat de temperatuur dan hoger is. Wanneer inundatie vroeg genoeg in de herfst optreedt, is ook groei in deze periode mogelijk, gevolgd door een diapauze in de winter. Opnieuw zijn dus de start van de inundatie en de lengte van de inundatieperiode van groot belang. De temperatuur van het water wordt gestuurd door de herkomst van het inundatiewater (aandeel grondwater), het microklimaat dat heerst in het broekbos en de hoeveelheid zoninstraling (Runhaar et al. 2013). Verder kan de troebelheid van het water en de kleur van het bodemsubstraat invloed hebben op de hoeveelheid warmte dat in het water geabsorbeerd wordt (Williams 2005).

Heterogeniteit in het microklimaat van broekbossen treedt op na het afsterven en/of omvallen van bomen, de zogenoemde 'gap-dynamics' (Batzer et al. 2006). Wanneer een boom omvalt in het broekbos creëert dit een opening in het bladerdak, waardoor meer licht de bodem kan bereiken. Dit leidt direct tot andere omstandigheden en wordt verder versterkt door veranderingen in de vegetatiestructuur en plantensoortensamenstelling op deze open plek. In sterk kwelgevoedde -en daardoor erg natte - broekbossen ontstaan vaak veel van dit soort open plekken, waardoor het bos meer het karakter van een moeras krijgt. Echter, kwantitatieve informatie over de relatie tussen de mate van beschaduwing en de samenstelling van de levensgemeenschap ontbreekt (Runhaar et al. 2013).

\section{(Grond)waterstand, zuurstofvoorziening en redoxpotentiaal}

\section{Vegetatie}

Broekbossen worden gekenmerkt door het langdurig optreden van natte, waterverzadigde omstandigheden waardoor de ondergrond tenminste een groot deel van het jaar zuurstofloos (tabel B4.1). Planten in broekbossen zijn aan deze zuurstofloze omstandigheden aangepast door het bezit van luchtweefsels waarmee zuurstof naar de wortels kan worden getransporteerd (onder meer de diverse zeggensoorten, dotterbloem, gele lis en kattenstaart) en/of door oppervlakkige beworteling. Door het gebrek aan zuurstof ontstaan in 
de ondergrond ook gereduceerde omstandigheden waarbij reductieprocessen optreden en waardoor voor planten toxische verbindingen worden gevormd, zoals ammonium, waterstofsulfide en tweewaardig ijzer en mangaan. Ook aan dergelijke omstandigheden zijn planten in broekbossen aangepast. Voor verschillende soorten met luchtweefsels is aangetoond dat ze in staat zijn het zuurstofgehalte in de directe omgeving van de wortels te verhogen. Dit leidt tot de oxidatie van potentieel toxische gereduceerde stoffen (Wheeler, 1999). Het neerslaan van geoxideerd ijzer is waarneembaar door de vorming van roest rondom de wortels van dergelijke planten (Runhaar et al. 2013).

Tabel B4.1 Grondwaterstandranges waarbij de verschillende broekbostypen in Nederland zijn aangetroffen op basis gegevens De Waal en Hommel (2005). Aangegeven is de gemiddeld hoogste grondwaterstand (GHG) en de gemiddeld laagste grondwaterstand (GLG), in cm onder maaiveld. Negatieve waarden geven waterstanden boven maaiveld (Runhaar et al. 2013).

\begin{tabular}{|c|c|c|c|c|c|c|c|c|}
\hline \multirow{2}{*}{\multicolumn{2}{|c|}{ Vegetatietype }} & \multirow[t]{2}{*}{$\mathrm{n}$} & \multicolumn{3}{|l|}{ GHG } & \multirow[b]{2}{*}{$\min$} & \multirow{2}{*}{$\begin{array}{l}\text { GLG } \\
\text { gem }\end{array}$} & \multirow[b]{2}{*}{$\max$} \\
\hline & & & $\min$ & gem & $\max$ & & & \\
\hline \multicolumn{9}{|c|}{ 39Aa1 Moerasvaren-elzenbroek } \\
\hline 39Aa1a & Thelypterido-Alnetum typicum & 5 & -10 & -8 & -5 & 2 & 6 & 15 \\
\hline 39Aa1b & Thelypterido-Alnetum sphagnetetosum & 5 & -2 & -4 & -5 & 5 & 9 & 15 \\
\hline 39Aa1c & Thelypterido-Alnetum caricetosum ripariae & 8 & -10 & -5 & 0 & 0 & 7 & 25 \\
\hline \multicolumn{9}{|c|}{ 39Aa2 Elzenzegge-Elzenbroek } \\
\hline 39Aa2a & Carici elongatae-Alnetum typicum & 6 & -15 & -11 & -5 & 10 & 32 & 48 \\
\hline 39Aa2b & $\begin{array}{l}\text { Carici elongatae-Alnetum cardaminetosum } \\
\text { amarae }\end{array}$ & 3 & -10 & -5 & 0 & 10 & 70 & 140 \\
\hline 39Aa2c & Carici elongatae-Alnetum ribetosum nigrae & 5 & -18 & -9 & -2 & 10 & 36 & 60 \\
\hline 39Aa2d & Carici elongatae-Alnetum rubetosum idaei & 6 & -5 & 2 & 15 & 50 & 78 & 110 \\
\hline 39Aa2e & Carici elongatae-Alnetum caricetosum curtae & 5 & -15 & 4 & 0 & 35 & 58 & 90 \\
\hline \multicolumn{9}{|c|}{ 39RG Romgemeenschappen Elzenbroek } \\
\hline 39RG1 & $\begin{array}{l}\text { RG Calamagrostis canescens-[Alnion } \\
\text { glutinosae] }\end{array}$ & 5 & -4 & 6 & 20 & 20 & 44 & 85 \\
\hline 39RG2 & RG Rubus fruticosus-[Alnion glutinosae] & 3 & -5 & 1 & 10 & 14 & 27 & 40 \\
\hline 39RG3 & RG Carex acutiformis-[Alnion glutinosae] & 8 & -15 & -9 & -3 & -5 & 2 & 10 \\
\hline 39RG4 & RG Urtica dioica-[Alnion glutinosae] & 5 & -5 & 6 & 20 & 22 & 57 & 200 \\
\hline \multicolumn{9}{|c|}{ Overige } \\
\hline $40 \mathrm{Aa2}$ & Carici curtae-Betuletum pubescentis & 7 & -10 & -4 & -2 & 20 & 29 & 40 \\
\hline 43Aa4 & Carici remotae-Fraxinetum & 4 & -5 & -2 & 0 & 5 & 21 & 35 \\
\hline 43Aa5 & Pruno-Fraxinetum & 6 & 5 & 31 & 60 & 50 & $>125$ & $>150$ \\
\hline
\end{tabular}

Hoewel volwassen elzen goed tegen overstromingen bestand zijn, komen elzen maar weinig voor op dynamische standplaatsen met regelmatige diepe overstroming en hoge stroomsnelheden, zoals in de uiterwaarden van de Waal en IJssel. Hier ontstaan zachthoutooibossen gedomineerd door wilgen (onder andere Schietwilg en Katwilg). Permanente inundatie wordt niet goed verdragen, waarschijnlijk mede omdat inundatie leidt tot eens sterke afname van de stikstofbinding en hiermee van de fotosynthese. Te sterke vernatting van elzenbroekbossen, waarbij elzen gedurende vrijwel het hele jaar in het water komen staan, kan leiden tot het afsterven van elzen. Op vrijwel permanent onder water staande standplaatsen worden elzen verdrongen door wilgenstruwelen (vooral Grauwe wilg) en moerasruigtes (Runhaar et al. 2013).

In de beekdalen worden de elzenbroekbossen op hoger gelegen delen vervangen door Vogelkers-Essenbossen (Pruno-Fraxinetum). Zoals te zien in tabel 4.4 worden deze gekenmerkt door dieper wegzakkende grondwaterstanden (Runhaar et al. 2013). 


\section{Fauna}

Het hydrologische regime van een broekbos is ook voor de ongewerveldenfauna de belangrijkste sturende factor. Het optreden van zowel overstroming met grond- en/of oppervlaktewater als periodieke uitdroging sturen direct de samenstelling en verspreiding van soorten binnen het broekbos (Mendelsson \& Batzer 2006). Volgens Wissinger (1999) zijn de belangrijkste vier componenten van het hydrologisch regime in broekbossen voor de fauna 1) de duur van inundatie/droogval, 2) de frequentie, amplitudo en tijdstip in het jaar van inundatie/droogval, 3) de voorspelbaarheid van het optreden van inundatie/droogval, en 4) de specifieke omstandigheden tijdens inundatie/droogval (bijv. stroming, waterkwaliteit en zuurstofgehalte). Aangezien inundaties en droogval veel voorkomende verschijnselen zijn in moerasecosystemen hebben zowel aquatische als (semi-)terrestrische ongewervelden in de loop van de evolutie een breed scala aan aanpassingen ontwikkeld om hier mee om te gaan (Williams 1996, Adis \& Junk 2002, Mendelsson \& Batzer 2006). Verschillen in inundatieregime tussen broekbossen hebben dan ook grote consequenties voor de soorten die er kunnen voorkomen. De voorspelbaarheid van het hydrologische regime maakt een aangeboren 'timing' of synchronisatie mogelijk met het optreden van inundaties (Uetz et al. 1979; Adis \& Junk 2002). Hoe dieren omgaan met inundaties en droogval verschilt sterk tussen (semi-)terrestrische en aquatische soorten (Runhaar et al. 2013).

Voor de meeste (semi-)terrestrische ongewervelden valt de periode van langdurige inundatie in het winterhalfjaar samen met de overwinteringsperiode. Dit heeft tot gevolg dat deze dieren zich in die periode niet of amper meer kunnen verplaatsen. De keuze van de overwinteringsplek moet dus afgestemd worden op het hydrologische regime van het broekbos. Drie plekken worden veelvuldig gebruikt als overwinteringslocatie (Zulka 1994; Riegel 1996; Stegner 1998; Hannig et al. 2006):

1. Aan de randen van het broekbos, in hoger gelegen delen van het beekdal (horizontale migratie op mesoschaal):

Horizontale migratie op mesoschaal is alleen mogelijk voor mobiele organismen, die in staat zijn relatief grote afstanden af te leggen binnen het beekdal; vliegend, lopend of kruipend. Dit soort seizoensmigratie is onder andere bekend van loopkevers in de uiterwaarden van grote rivieren (Zulka 1994; Turin 2000).

2. Binnen het broekbos, boven de waterlijn (microschaal, verticale migratie op structuurelementen):

Verticale micromigratie treedt op binnen het broekbos zelf. De afstanden die hierbij afgelegd moeten worden zijn dus veel kleiner dan bij horizontale migratie. Alle boven het water uitstekende elementen kunnen worden gebruikt: bomen en hun stamvoet, stronken en stobben, planten enzovoorts.

3. Binnen het broekbos, onder water.

Gradiënten in bodemreliëf op mesoschaal (hoog en laag gelegen delen bos) en op microschaal structuurelementen in de vorm van elzenstobben en zeggenpollen zijn dus essentieel voor deze soorten (figuur 4.2).

Overwintering onder de schors van boomstammen is waargenomen bij bijvoorbeeld loopkevers, pissebedden, duizendpoten en miljoenpoten (Riegel 1996; Tajovský 1999). In graslandecosystemen spelen hoge graspollen een belangrijke rol als overwinteringshabitat (Luff 1966). In broekbossen vervullen zeggenpollen waarschijnlijk een vergelijkbare functie, maar kwantitatieve gegevens hierover ontbreken. Tenslotte vindt ook overwintering plaats onder water. Sommige larven of volwassen dieren kruipen in holtes in dood, rottend hout of in de bodem (Pižl 1999). Bij inundatie blijven luchtbellen achter in deze holtes, die vervolgens gebruikt worden voor de zuurstofvoorziening (Braccia \& Batzer 2001). Andere 
ongewervelden zijn nog beter aangepast; ze hebben fysiologische en morfologische aanpassingen waardoor ademhaling onder water mogelijk is (Adis 1997, Pižl 1999). Daarnaast hebben bepaalde groepen eieren of cocons die resistent zijn tegen overstromingen (Pižl 1999).

Voor veel aquatische ongewervelden vormt juist het winterhalfjaar, en dan vooral herfst en voorjaar, de meest actieve periode. Broekbossen kunnen beschouwd worden als najaarswateren volgens de definitie van Wiggins et al. (1980), oftewel water bevattend vanaf circa oktober tot uiterlijk juni het volgende jaar. Wanneer in het najaar inundatie optreedt van de laaggelegen delen van het bos en de terrestrische fauna verdwijnt of inactief wordt, treden de aquatische soorten naar de voorgrond. Door Wiggins et al. (1980) worden vier strategieën onderscheiden binnen deze groep ongewervelden:

1. Overzomerende residenten. Alleen in staat tot passieve dispersie, deze dieren overzomeren in diapauze in het broekbos in een droogteresistent levensstadium, hetzij als adult, juveniel, ei of cocon. Komt voor bij meiofauna (o.a. Copepoda, Cladocera, Ostracoda) en bij macrofauna (Oligochaeta, Mollusca).

2. Overwinterende najaar- of voorjaarontwikkelaars die in staat zijn tot actieve dispersie. Eiafzet afhankelijk van water, reproductie moet dus plaatsvinden laat in het najaar nadat inundatie heeft plaatsgevonden of in het voorjaar voordat water verdwenen is. Overzomeren in broekbos als adult.

3. Overwinterende voorjaarsontwikkelaars. Ovipositie onafhankelijk van water, adulten zetten eieren af op droge bodem in de zomer. Na inundatie komen eieren uit. Steekmuggen (Culicidae) van genera Aedes en Ochlerotatus, Trichoptera: Trichostegia minor.

4. Niet in het broekbos overwinterende voorjaarsmigranten. Ovipositie afhankelijk van water, adulten koloniseren geïnundeerd broekbos in het vroege voorjaar vanuit nabijgelegen permanente wateren. Snelle ontwikkeling, zodat nieuwe generatie adulten het broekbos voor de zomer weer kan verlaten. Veel Coleoptera en Hemiptera.

Het samenspel tussen inundatie en het bodemreliëf van het broekbos is van groot belang voor de fauna. Laaggelegen delen in het broekbos, bijvoorbeeld plekken waar de wortelkluit van een omgevallen boom heeft gezeten, oude meanders of door de mens gegraven greppels, kunnen langer water bevatten dan hoger gelegen delen en zo meer mogelijkheden bieden voor aquatische ongewervelden. Deze restwateren kunnen bijvoorbeeld als refugium dienen voor soorten die permanent water nodig hebben. Wanneer de poeltjes tijdelijk worden verbonden bij inundatie, kunnen soorten zich door het water verplaatsen. Vice versa, permanent onverzadigde bulten op de bosbodem kunnen dezelfde rol vervullen voor de terrestrische fauna. De overgangen tussen beide typen zijn uitermate geschikt voor semiaquatische soorten. Kortom, het hydrologisch regime in een broekbos kan dus sterk gedifferentieerd zijn en juist deze heterogeniteit leidt ertoe dat een groot aantal soorten tegelijkertijd in het bos kan voorkomen (Runhaar et al. 2013).

Tijdens inundatie treden er grote veranderingen op in fysisch-chemische omstandigheden, zoals zuurstofbeschikbaarheid (Sharitz \& Batzer 1999). De samenstelling van de bodem/strooisellaag (hoeveelheid strooisel, voedselrijkdom bodemsubstraat) speelt hierbij een grote rol. Aangezien de meeste broekboswateren sterk saproob zijn, komen anoxische of hypoxische omstandigheden veel voor, met name op het moment dat de watertemperatuur relatief hoog is (najaar en voorjaar). Productie door waterplanten (bijv. 
Hottonia palustris) en algen (met name diatomeeën in het vroege voorjaar, wanneer voldoende zonlicht kan doordringen tot in het water) is relatief laag ten opzichte van het verbruik bij de afbraak van organisch materiaal (Runhaar et al. 2013). De meeste ongewervelden hebben daarom aanpassingen aan de lage zuurstofbeschikbaarheid, zowel de aquatische fauna als de onder water overwinterende (semi-)terrestrische fauna (Van der Valk 2006; Mendelsson \& Batzer 2006).

Er kunnen twee hoofdgroepen worden onderscheiden: luchtademhalers en waterademhalers (Eriksen et al. 1984). Met name luchtademhaling komt veel voor. Sommige soorten nemen een luchtbel mee onder water (waterkevers) terwijl anderen adembuizen hebben waarmee ze direct contact met de lucht kunnen hebben (larven van vliegen en muggen). Een bijzondere vorm van luchtademhaling komt voor bij sommige muggen(Coquillettidia richiardii) en keverlarven (o.a. Donacia): deze boren met hun adembuis de met lucht gevulde weefsels van de moerasplanten aan. Soorten waarbij zuurstof uit het water wordt opgenomen hebben verschillende aanpassingen om aan hun zuurstofvraag te kunnen voldoen. Deze aanpassingen kunnen fysiologisch zijn, zoals het kunnen overschakelen naar een anaeroob metabolisme bij een lage zuurstofbeschikbaarheid of het hebben van hemoglobine of andere zuurstofbindende verbindingen in de lichaamsvloeistof om zuurstofopname te bevorderen. Daarnaast komen ook gedragsaanpassingen voor. Verdermuglarven (Diptera: Chironomidae) en borstelwormen (Oligochaeta: Tubificidae), die vaak in zelf geconstrueerde buisjes leven, maken wapperende bewegingen om watercirculatie op gang te brengen waardoor meer zuurstof aangevoerd wordt. Op grotere schaal is mobiliteit belangrijk, waardoor soorten in staat zijn zich te verplaatsen naar meer zuurstofrijke delen van het waterlichaam (Runhaar et al. 2013)..

\section{Zuurbuffering (kwel) en nutriëntenhuishouding}

\section{Vegetatie}

In de beekdalen vormt aanvoer van basenrijk grondwater (kwel) een belangrijke randvoorwaarde voor het ontstaan van goed ontwikkelde elzenbroekbossen. De grondwateraanvoer zorgt voor buffering van de zuurgraad én voor permanent ondiepe grondwaterstanden. De zuurgraad van het bodemwater en de bovengrond is mede afhankelijk van de basenrijkdom van het grondwater en van de mate waarin zich regenwaterlenzen vormen boven het basenrijke grondwater. Op plekken waar basenrijk grondwater aan de oppervlakte uittreedt, op natte kwelplekken en in bronnetjesbossen, komen respectievelijk het Veldkers-Elzenbroek (Carici elongatae-Alnetum cardaminetosum amarae) en het Goudveil-Essenbos voor (Carici remotae-Fraxinetum). Deze worden gekenmerkt door een relatief hoge $\mathrm{pH}$ (tabel B4.1) en grondwaterstanden die het gehele jaar dicht aan maaiveld staan. Op plekken waar zich boven het basenrijke grondwater regenwaterlenzen vormen komen zuurdere vormen van het elzenbroekbos voor (Carici elongatae-Alnetum caricetosum curtae) waarin ook veenmossen een belangrijke rol spelen. Bij verdere verzuring kan zich hieruit het Zompzegge-berkenbroek (Carici curtae-Betuletum pubescentis) ontwikkelen (Runhaar et al. 2013).

Overstroming met oppervlaktewater vormt indirect een belangrijke factor voor het ontstaan van het Zwarte bes-Elzenbroek (Carici elongatae-Alnetum ribetosum nigrae) en het Vogelkers-Essenbos (Puno-Fraxinetum). Het voorkomen van deze bostypen is namelijk gebonden aan standplaatsen waar in het verleden overstromingen hebben plaatsgevonden en de bodem is aangerijkt met mineralen (kleiige en lemige beekafzettingen). In hoeverre deze bostypen ook kunnen ontstaan bij overstroming met het huidige, vaak relatief voedselrijke oppervlaktewater is echter onduidelijk (Runhaar et al. 2013). 
Tabel B4.1 pH-ranges voor het bodemwater waarbij verschillende broekbostypen in Nederland zijn aangetroffen op basis gegevens De Waal en Hommeln (2005; uit Runhaar et al. 2013).

\begin{tabular}{|c|c|c|c|c|c|}
\hline \multicolumn{2}{|c|}{ Vegetatietype } & \multirow[t]{2}{*}{$\mathrm{n}$} & \multicolumn{3}{|c|}{ pH-bodemwater } \\
\hline & & & $\min$ & gem & $\max$ \\
\hline \multicolumn{6}{|c|}{ 39Aa1 Moerasvaren-elzenbroek } \\
\hline 39Aa1a & Thelypterido-Alnetum typicum & 5 & 4,6 & 5,9 & 6,6 \\
\hline 39Aa1b & Thelypterido-Alnetum sphagnetetosum & 5 & 4,3 & 4,8 & 5,4 \\
\hline 39Aa1c & Thelypterido-Alnetum caricetosum ripariae & 8 & 4,7 & 5,3 & 5,9 \\
\hline \multicolumn{6}{|c|}{ 39Aa2 Elzenzegge-Elzenbroek } \\
\hline $39 A a 2 a$ & Carici elongatae-Alnetum typicum & 6 & 5,2 & 6,0 & 6,9 \\
\hline 39Aa2b & $\begin{array}{l}\text { Carici elongatae-Alnetum cardaminetosum } \\
\text { amarae }\end{array}$ & 3 & 6,1 & 6,2 & 6,3 \\
\hline 39Aa2c & Carici elongatae-Alnetum ribetosum nigrae & 3 & 5,3 & 6,0 & 6,9 \\
\hline 39Aa2d & Carici elongatae-Alnetum rubetosum idaei & 3 & 5,3 & 5,9 & 6,9 \\
\hline 39Aa2e & Carici elongatae-Alnetum caricetosum curtae & 5 & 3,5 & 4,8 & 6,2 \\
\hline \multicolumn{6}{|c|}{ 39RG Romgemeenschappen Elzenbroek } \\
\hline 39RG1 & $\begin{array}{l}\text { RG Calamagrostis canescens-[Alnion } \\
\text { glutinosae] }\end{array}$ & 4 & 5,2 & 5,6 & 5,9 \\
\hline 39RG2 & RG Rubus fruticosus-[Alnion glutinosae] & 2 & 5,7 & 6,0 & 6,2 \\
\hline 39RG3 & RG Carex acutiformis-[Alnion glutinosae] & 5 & 4,0 & 5,2 & 6,7 \\
\hline 39RG4 & RG Urtica dioica-[Alnion glutinosae] & 4 & 5,6 & 6,3 & 7,3 \\
\hline \multicolumn{6}{|c|}{ Overige } \\
\hline $40 \mathrm{Aa2}$ & Carici curtae-Betuletum pubescentis & 7 & 3,4 & 4,4 & 5,4 \\
\hline 43Aa4 & Carici remotae-Fraxinetum & 2 & 7,0 & 7,2 & 7,3 \\
\hline
\end{tabular}

Elzen kunnen in hun wortelknolletjes aanzienlijke hoeveelheden stikstof binden (Carlson \& Dawson, 1985; Akkermans,1971 (in Hamdi, 1982)). Een groot deel van het gefixeerde stikstof in elzenbroekbossen is gebonden in de vorm van organisch materiaal. Via decompositie en mineralisatie kan dit weer vrijkomen (Rodriguez-Barrueco e.a., 1984). Stikstof komt echter relatief moeilijk vrij uit organisch materiaal, omdat het overwegend direct gebonden is aan koolstof (C-N verbinding). Deze verbindingen kunnen alleen via complexe enzymatische reacties (microbiologisch processen) worden afgebroken (Vitousek e.a., 1991; Aerts e.a., 2006). Daarnaast kunnen vanwege de natte omstandigheden de stikstofverliezen als gevolg van denitrificatie groot zijn (Runhaar et al. 2013).

De aanwezigheid van elzen kan ook de turn-over (opname en vrijkomen door afbraak) van andere nutriënten en basen in een bosvegetatie verhogen (Binkley e.a., 1992; Giardina e.a., 1995; Selmants et al., 2005). Goed ontwikkelde Elzenbroekbossen worden gevoed door kwelwater dat doorgaans rijk is aan calcium en ijzer. Zowel calcium als ijzer zijn goed in staat om fosfaat te binden in de bodem, waardoor de concentratie vrij fosfaat in het bodemvocht en de waterlaag op grondwater gevoede locaties doorgaans laag is. Maar ook de aanwezigheid van Elzen speelt een rol in de fosforcyclus. Zo leidt in relatief $P$ rijke bodems de aanwezigheid van Alnus rubra (Rode els) tot een afname van de gemakkelijk extraheerbare $P$-fractie en een toename van de fractie in organische vorm vastgelegd $P$ (Compton en Cole, 1998).

Het is niet duidelijk welk macronutriënt in de ondergroei van goed ontwikkelde broekbossen het meest beperkend is. Uit de nutriëntenverhoudingen in planten kan in principe worden afgeleid welk nutriënt beperkend is (Olde Venterink 2002). Helaas is er vrijwel niets te vinden over de nutriëntenratio van planten die voorkomen in de ondergroei van broekbossen, en dus over het antwoord op de vraag of de vegetatie in broekbossen fosfor dan wel stikstof gelimiteerd is. Een beperkt aantal analyses aan het plantmateriaal van 
Carex pseudocyperus (Hoge cyperzegge) afkomstig uit het Beeselsbroek, indiceert dat deze soort met name stikstof gelimiteerd is $(\mathrm{N}: \mathrm{P}=7,1 ; \mathrm{N}: \mathrm{K}=0,6 ; \mathrm{K}: \mathrm{P}=13,2$; Lucassen, ongepubliceerde data) (Runhaar et al. 2013).

\section{$\underline{\text { Fauna }}$}

Hoge nutriënten-, macro-ionenconcentraties en humuszuren kunnen zowel positieve en negatieve effecten hebben op zowel de aquatische als de overwinterende (semi)terrestrische fauna (Williams 2005; Van der Valk 2006). Wanneer in het najaar inundatie optreedt komen veel voedingsstoffen vrij uit de afgevallen bladeren en de bodem. Algen kunnen profiteren van deze piek in voedingsstoffen en kunnen vervolgens weer als voedsel dienen voor de macrofauna. Negatieve effecten kunnen optreden wanneer voor organismen schadelijke stoffen vrijkomen, bijvoorbeeld als zuurstofloze omstandigheden optreden (toxische verbindingen zoals sulfide en nitriet) de zuurgraad van het water sterk daalt of veel humuszuren vrijkomen. De concentratie opgeloste stoffen in het water varieert meer in tijdelijke wateren dan in permanente wateren. Dit is het gevolg van een combinatie van uitdroging, wateraanvulling en bevriezing gedurende de inundatieperiode (Runhaar et al. 2013). De elektrische geleidbaarheid kan bijvoorbeeld wel met een factor 4 fluctueren gedurende de inundatieperiode (Williams 2005).

\section{Bodemsamenstelling (organisch materiaal) en structuur}

\section{Vegetatie}

Broekbossen kunnen zich ontwikkelen op een groot aantal verschillende substraten, mits de waterhuishouding geschikt is: permanent nat en bij voorkeur kwel gevoed. Door de permanent natte omstandigheden wordt de afbraak van organisch materiaal geremd en ontstaat uiteindelijk een veenbodem. Bij elzenbroekbossen in de beekdalen ontstaat broekveen, een veentype dat behalve door de aanwezigheid van houtresten ook wordt gekenmerkt door een relatief groot aandeel aan minerale bestanddelen (vooral lutum) als gevolg van periodieke overstroming met beekwater (Runhaar et al. 2013). Het organische materiaal heeft een relatief lage $\mathrm{C} / \mathrm{N}$ verhouding (Hendriks 1992).

Broekbossen zijn semi-aquatische milieus, gekenmerkt door de continue aanwezigheid van gradiënten van de waterfase tot droge bodem in ruimte. Deze gradiënten kunnen voorkomen op verschillende landschappelijke schaalniveaus (Runhaar et al. 2013):

- Beekdallandschap: van laaggelegen natte broekbosdelen naar hogere droge randen beekdal.

- Broekbos: afwisseling van vrijwel permanent water bevattende poelen, oude meanders en greppels en droge hogere terreindelen.

- Habitat: Stamvoeten en omgevallen bomen liggen ver boven bosbodem en vormen zo permanent droge habitats, zelfs bij volledige inundatie. 


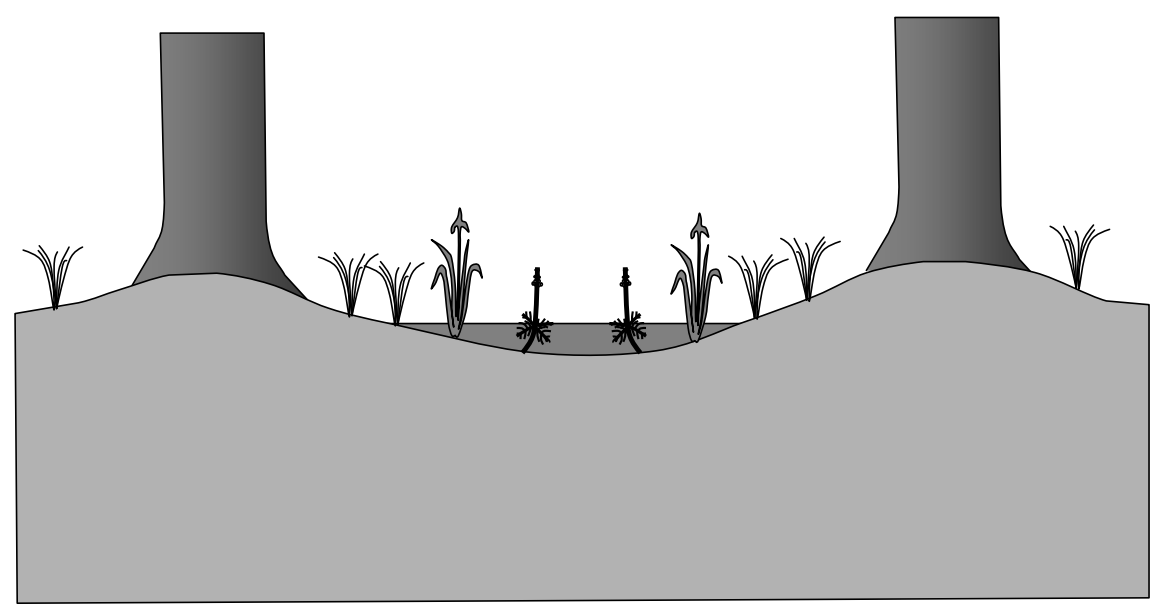

Figuur B4.2 Kenmerkend voor broekbossen is de afwisseling van natte en droge delen waardoor op korte afstand aan terrestrische en aquatische omstandigheden aangepaste soorten voor kunnen komen (Runhaar et al. 2013).

Op beekdallandschap-schaal zijn de overgangen van de natte broekbossen naar drogere bostypen belangrijk, omdat de laatste als overwinteringslocatie dienen voor soorten die niet bestand zijn tegen winterinundaties met grond- of beekwater. Binnen het broekbos bestaat meestal een afwisseling van droge en (vrijwel) permanent natte delen. De stamvoeten van elzen spelen een belangrijke rol in het ontstaan van mesostructuren (Van der Werf, 1991), doordat de stamvoet en het begin van de horizontale wortels over het algemeen boven de waterspiegel uitsteken. Het mozaïek van hoogteverschillen dat hierdoor wordt gecreëerd leidt tot de beschikbaarheid van vochtgradiënten: relatief droog op de stamvoet en nat in de laagtes tussen de bomen (figuur B4.2). Windworp is een frequent optredend verschijnsel op de zeer natte broekbosbodem en kan het aanwezige microreliëf nog verder versterken. In licht verdroogde broekbossen kan het patroon worden versterkt door afbraak van veen: door veenafbraak daalt het maaiveld tussen de bomen, maar de stamvoeten en de oppervlakkige wortels dalen niet of nauwelijks mee (Runhaar et al. 2013).

Door de afwisseling aan natte en droge milieus kunnen op korte afstand typische waterdieren en -planten voorkomen naast typisch terrestrische soorten. Beide habitats herbergen hun eigen levensgemeenschap, maar vooral de overgang tussen beide typen is bijzonder soortenrijk. Daarnaast maken veel soorten gebruik van zowel het aquatische als het terrestrische milieu tijdens de verschillende fases van hun levenscyclus. De stamvoeten dienen als hoogwatervluchtplaats voor veel (semi-)terrestrische organismen. Voor de fauna is ook de vegetatiestructuur van belang, bijvoorbeeld de aanwezigheid van pollen vormende zeggenvegetaties. Indirect reguleert de dichtheid en groeivorm van de vegetatie het microklimaat boven de bodem, en direct heeft de architectuur van de vegetatie invloed op de fauna door het creëren van structuurvariatie (Runhaar et al. 2013). Spinnen worden bijvoorbeeld direct beïnvloed door de vegetatiestructuur van de kruidlaag (Döbel et al., 1990).

\section{Fauna}


De grote hoeveelheid elzenblad dat in de herfst op de bodem terecht komt en de daarmee geassocieerde micro-organismen tijdens het afbraakproces zijn de voornaamste voedselbronnen voor veel ongewervelden. Herbivorie speelt een onderschikte rol, en beperkt zich vooral tot het afgrazen van algen door bijvoorbeeld slakken (Taylor \& Batzer 2010). Voor detritivore ongewervelden, zoals miljoenpoten, (water)pissebedden, kokerjuffers en kevers, is met name de hoeveelheid en samenstelling van het strooisel (o.a. $\mathrm{C} / \mathrm{N}$ ratio, hoeveelheid beschikbaar P) van groot belang (Uetz et al. 1979; Coleman et al. 2004; Tajovský \& Wytwer 2009). Het gaat voor deze dieren hooguit om de bovenste centimeters van de bodem, waar nog bladeren en takjes aanwezig zijn en de daaronder liggende gedeeltelijk omgezette laag organisch materiaal. De hoge grondwaterstand in broekbossen heeft tot gevolg dat de fauna in de onderliggende bodem relatief soortenarm is. In feite zijn alleen de bovenste paar centimeter van de bodem geschikt als habitat; de zuurstofloze omstandigheden in de permanent met water verzadigde dieper gelegen delen maken dit milieu te extreem voor de meeste soorten (Runhaar et al. 2013).

Wormen vormen de belangrijkste groep macrofauna in het strooisel van een broekbos en spelen een belangrijke rol in het functioneren van het broekbosecosysteem. Zo waren de aardwormen (Lumbricus) in een beekbegeleidend broekbos in Michigan (V.S.) in staat $94 \%$ van de jaarlijkse bladval binnen 4 weken te consumeren (Knollenberg et al. 1985). Op de geïnundeerde plekken spelen waterpissebedden (Isopoda: Asellidae), kokerjuffers (Trichoptera: Limnephilidae) en keverlarven (Coleoptera: Scirtidae) een belangrijke rol bij de omzetting van grof naar fijn organisch materiaal (Runhaar et al. 2013).

Naast het strooisel is ook hout, in de vorm van afgevallen takken en omgevallen bomen, op de bosbodem van groot belang. De rottende boomstammen worden naast een refugium bij inundatie ook gebruikt als voedselbron voor larven van diverse hout-etende kevers, vliegen en muggen (Runhaar et al. 2013). De mossen en paddenstoelen die op het hout voorkomen vervullen een belangrijke rol voor veel soorten als schuilplaats of voedselbron (Rief 1996).

\section{Ruimtelijke samenhang}

Vaak liggen natte broekbossen in de beekdalen geïsoleerd en worden ze omringd door droge bossen of landbouwgrond. Dit wil zeggen dat het areaal dat ingenomen wordt door een soort bestaat uit een serie kleine geïsoleerde deelpopulaties van zowel planten en dieren, die met elkaar verbonden zijn door dispersie van individuen. Samen vormen de deelpopulaties een 'metapopulatie', zoals beschreven door Levins (1969) en Hanski (1999). Wanneer een deelpopulatie verdwijnt, bijvoorbeeld doordat in een extreem droog jaar de inundatieduur van het broekbos niet lang genoeg is om de levenscyclus van de dieren te kunnen volbrengen, kan deze locatie opnieuw gekoloniseerd worden vanuit omliggende deelpopulaties (Runhaar et al. 2013). De soortensamenstelling van planten en dieren in een broekbos is het gevolg van een combinatie van deterministische mechanismen (de structurerende rol van de heersende milieuomstandigheden) en het gevolg van stochastische processen (toevallige kolonisatie van locaties en extinctie van bestaande populaties) (Leibold et al. 2004). Drie eigenschappen van de deelpopulaties zijn belangrijk voor de uitwisseling tussen deelpopulaties (Batzer et al. 2006):

- het aantal individuen dat dispersie vertoont binnen de deelpopulaties,

- de mate van diversiteit aan omstandigheden binnen het areaal (treden extremen bijvoorbeeld synchroon of asynchroon op over alle broekboslocaties),

- de dispersiecapaciteit en -mogelijkheden van de soorten. 
De mate van isolatie van een broekbos is bepalend voor het functioneren van de metapopulatie. Dit kan isolatie zijn als gevolg van afstand tot het volgende broekbos, maar ook isolatie door dispersiebarrières (grote wateroppervlaktes of uitgestrekte landbouwgebieden). Omdat veel broekbossoorten ook kunnen voorkomen in moerasvegetaties en elzenbosjes zijn de structuur van het omringende gebied en de aard van de groen-blauwe dooradering ook van belang. Het verdwijnen van moerasjes en soortenrijke oevers en verdroging van broekbossen kunnen isolatie van de overgebleven restanten in de hand werken, doordat daarmee 'stepping stones' voor soorten wegvallen. De mate van isolatie is niet alleen afhankelijk van de afstand tot nabijgelegen broekbossen, maar ook van de dispersiecapaciteit van soorten (Runhaar et al. 2013).

Binnen de aquatische fauna is het vermogen tot dispersie over het algemeen goed ontwikkeld (Bilton et al. 2001). Sommige soorten kunnen vliegend nieuwe locaties bereiken, terwijl andere zich passief verplaatsen, bijvoorbeeld door de wind. Een andere manier om broekbossen te koloniseren is tijdens inundaties. Poeltjes in de bossen worden tijdelijk verbonden, waarna soorten zich door het water kunnen verplaatsen of met het beekwater uit bovenstroomse broekbossen kunnen worden aangevoerd. Ook voor moerasplanten geldt dat veel soorten zaad vormen dat via water kan worden aangevoerd (Runhaar et al. 2013).

Behalve de mate van isolatie is ook de oppervlakte van het broekbos een belangrijke factor. In de regel herbergen grotere oppervlaktes van een habitat meer soorten dan kleine habitats. Dit is vooral het gevolg van het feit dat grotere habitats een hogere diversiteit aan microhabitats herbergen. Deze habitatheterogeniteit biedt mogelijkheden voor een groter aantal soorten, vaak specialisten (Batzer et al. 2006). 